\title{
The Farm Press, Reform, and Rural Change, 1895-1920
}

John J. Fry 


\title{
STUDIES IN AMERICAN POPULAR History AND CUlture
}

\author{
Edited by \\ Jerome Nadelhaft
}

University of Maine

A Routledge Series 


\title{
STUdies IN AMERICAN POPULAR HISTORY AND CULTURE
}

\author{
Jerome NADELhaft, General Editor
}

Deconstructing Post-WWII New

YORK CITY

The Literature, Art, Jazz, and

Architecture of an Emerging Global

Capital

Robert Bennett

RETHINKING THE RED SCARE

The Lusk Committee and New York's

Crusade against Radicalism,

1919-1923

Todd J. Pfannestiel

Hollywood and the Rise of Physical

Culture

Heather Addison

HOMELESSNESS IN AMERICAN LITERATURE

Romanticism, Realism, and Testimony

John Allen

NO WAY OF KNOWING

Crime, Urban Legends, and the Internet

Pamela Donovan

The Making of THe Primitive Baptists

A Cultural and Intellectual History of the Antimission Movement, 1800-1840

James R. Mathis

WOMEN AND COMEDY IN SOLO

PERFORMANCE

Phyllis Diller, Lily Tomlin, and

Roseanne

Suzanne Lavin

THE LITERATURE OF IMMIGRATION AND

RACIAL FORMATION

Becoming White, Becoming Other,

Becoming American in the Late

Progressive Era

Linda Joyce Brown

Popular Culture and the Enduring

MYTH OF CHICAGO, 1871-1968

Lisa Krissoff Boehm
AMERICA'S FIGHT OVER WATER

The Environmental and Political Effects

of Large-Scale Water Systems

Kevin Wehr

Daughters of Eve

Pregnant Brides and Unwed Mothers in Seventeenth-Century Massachusetts

Else L. Hambleton

NARRATIVE, Political UnCONSCIOUS

AND RaCial ViolenCE IN WILMINGTON, North CAROLINA

Leslie H. Hossfeld

VALIDATING BACHELORHOOD

Audience, Patriarchy, and Charles

Brockden Brown's Editorship of the

Monthly Magazine and American

Review

Scott Slawinski

CHILDREN AND THE CRIMINAL LAW IN

CONNECTICUT, 1635-1855

Changing Perceptions of Childhood

Nancy Hathaway Steenburg

BOOKS AND LIBRARIES IN AMERICAN

SOCIETY DURING WORLD WAR II

Weapons in the War of Ideas

Patti Clayton Becker

Mistresses of the Transient Hearth

American Army Officers' Wives and

Material Culture, 1840-1880

Robin Dell Campbell

The FArm Press, ReForm, AND RuRAL

Change, 1895-1920

John J. Fry 


\title{
The Farm Press, Reform, AND RuRAL CHANGE, 1895-1920
}

\author{
John J. Fry
}

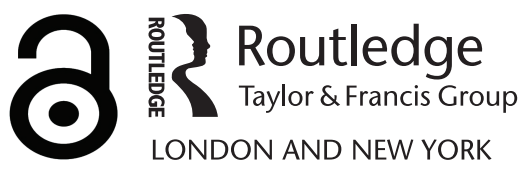


First published 2005 by Routledge

Published 2017 by Routledge

2 Park Square, Milton Park, Abingdon, Oxon OX14 4RN

711 Third Avenue, New York, NY 10017, USA

Routledge is an imprint of the Taylor \& Francis Group, an informa business

First issued in paperback 2012

Copyright (C) 2005 Taylor \& Francis

The Open Access version of this book, available at www.tandfebooks.com, has been made available under a Creative Commons Attribution-Non Commercial-No Derivatives 4.0 license.

ISBN-13: 978-0-415-97286-4 (hbk)

ISBN-13: 978-0-415-65241-4 (pbk)

Library of Congress Card Number 2004029632

\section{Library of Congress Cataloging-In-Publication Data}

Fry, John J.

The farm press, reform, and rural change, 1895-1920 / by John J. Fry.

p. cm. -- (Studies in American popular history and culture)

Summary: An in-depth look at producers and readers of Midwestern farm newspapers at the turn of the twentieth century.

Includes bibliographical references and index.

ISBN 0-415-97286-8

1. Journalism, Agricultural--Middle West--History--20th century 2.

Journalism, Agricultural--Middle West--History--19th century. I. Title.

II. American popular history and culture (Routledge (Firm))

\section{T\&Finforma}

Taylor \& Francis Group is the Academic Division of T\&F Informa plc.
Visit the Taylor \& Francis Web site at http://www.taylorandfrancis.com

and the Routledge Web site at http://www.routledge-ny.com 
To Paula - "You're the Inspiration" 
Page Intentionally Left Blank 


\section{Contents}

List of Tables $\quad$ ix

List of Maps $\quad$ xi

List of Abbreviations $\quad$ xiii

Acknowledgments $\quad$ xv

Introduction

The Rural Midwest and the Farm Press During the Progressive Era xvii

Chapter One

"First Class Papers" and "Never-Stop Papers": Twenty-Five

Years of the Midwestern Farm Press

Chapter Two

Editors and Publishers: The Faces Behind the Midwestern Farm Press

Chapter Three

"What Farmers Read and Liked": Scenes of Reading in the Rural Midwest

Chapter Four

"Who Read the Agricultural Journals?": Farm Newspaper Subscribers in the Lower Midwest

Chapter Five

"Innumerable Little White Churches": The Rural Church and the Midwestern Farm Press

Chapter Six

"The School House at the Crossroads": The Rural School and the Midwestern Farm Press 
Chapter Seven

"Why Leave the Farm?": The Rural Family and the

Midwestern Farm Press

Conclusion

"Good Farming_Clear Thinking-Right Living": The Uses

of Midwestern Farm Newspapers

Epilogue

Midwestern Farm Newspapers Since the 1920s

Notes

Bibliography

Index 


\section{List of Tables}

Table 1 Circulation Figures for Selected Midwestern Farm Newspapers

Table 2 Circulation Figures for Midwestern Farm

Newspapers Compared to Census Figures

for Number of Farms and Total Population $\quad 16$

Table 3 Advertising in Selected Midwestern Farm Newspapers

Table 4 Farm Papers Received and/or Read by Rural

Midwesterners

Table 5 Books Bought and/or Read by Rural Midwesterners

Table 6 Magazines Received and/or Read by Rural

Midwesterners

Table $7 \quad$ Newspapers from Large Cities Received and/or

Read by Rural Midwesterners

Table 8 References by Rural Midwesterners to Types of Publications by Gender

Table 91913 U.S.D.A. Survey-Farmers Taking Agricultural Papers

Table 101913 U.S.D.A. Survey-Farmers Stating Agency Most Helpful in Their Farming

Table 111917 University of Iowa Survey-Residents Receiving Farm Newspapers

Table 12 Carl C. Taylor Survey of a Southeast Missouri

Community-Respondents Receiving Farm

Newspapers

Table 13 The Subscription List of William H. Mills-

Occupations

Table 14 The Subscription List of William H. Mills-Economic 
Table 15 The Subscription List of William H. Mills-Economic Status of Renters

Table 16 The Subscription List of William H. MillsPlace of Origin

Table 17 Churches and Church Membership in Urban and Rural Areas in 1926

Table 18 Circulation Figures for Midwestern Farm Newspapers Compared to Census Figures for Number of Farms and Total Population 


\section{List of Maps}

Map 1 The Lower Midwest

$\mathrm{xxv}$

Map 2 Tour of the Lower Midwest

79 
Page Intentionally Left Blank 


\section{Abbreviations}

IH Iowa Homestead

ISHL Illinois State Historical Library, Springfield, Illinois

ISU Special Collections Department, Iowa State University Library, Ames, Iowa

IWA Iowa Women's Archives, University of Iowa Libraries, Iowa City, Iowa

MR Missouri Ruralist (Includes: The Ruralist, 1902-1910; Missouri Ruralist, 1902-1910)

NIU Earl W. Hayter Regional History Center, Northern Illinois University, DeKalb, Illinois

PF Prairie Farmer

SHSI-DM Manuscripts Department, State Historical Society of Iowa, Des Moines, Iowa

SHSI-IC Special Collections Department, State Historical Society of Iowa, Iowa City, Iowa

UI Special Collections Department, University of Iowa Libraries, Iowa City, lowa

UIUC University of Illinois Archives, Urbana-Champaign, Illinois

WF Wallaces' Farmer (Includes: Wallaces' Farm and Dairy, 1895; Wallaces' Farmer and Dairyman, 1895-1899; Wallaces' Farmer, 1899-1920) 
Page Intentionally Left Blank 


\section{Acknowledgments}

A book is the work of many people, not one. While this may be a cliché, that does not make it any less true. I thank the following individuals for aiding my work in a variety of ways. Any mistakes, misrepresentations, and misinterpretations are my responsibility, not theirs.

First and foremost, I thank God for the gift of His Son Jesus Christ, who gave His life on the cross to pay for my sins. Because of Christ's sacrifice I've been forgiven and can live for Him. I thank God for blessing me with the abilities necessary to complete this book and for providing for my family materially while I have worked on it. I have never been without employment and we have never lacked anything, even after Paula left the paid workforce. I pray that my work is pleasing to Him and brings Him glory.

Many thanks are due to all the scholars who have read parts of this manuscript and provided helpful comments. Professors Malcolm Rohrbough and Ken Cmiel at the University of Iowa never failed to give good advice; I only wish that I had heeded it more. Thanks to Professors T. Dwight Bozeman, Michael Cahall, Jason Duncan, Robert McMath, John Miller, Joanne Passet, Christine Pawley, James Smylie, and Fred Spletstoser. Thanks also to Marvin Bergman and Anna-Lisa Cox.

Funding for this project came from a number of sources. Final work on the manuscript was funded by a Trinity Research Fellowship from Trinity Christian College in Palos Heights, Illinois. Thanks to the Professional Development Committee and Provost Liz Rudenga for awarding me the fellowship and to Bob Rice and Russ Reeves for rearranging their schedules in response to it. The Graduate College at the University of Iowa supported my work with an Iowa Fellowship. Thanks are also due to the citizens of Iowa who support the University of Iowa with their tax dollars.

Archives research brings a large number of debts. At the University of Iowa Main Library, thanks to Joel Maxey in Stacks, Amy Fuls and Cheryl Huyck in Interlibrary Loan, John Elson in Government Documents, David 
Schoonover and Kathy Hodson in Special Collections, and Karen Mason at the Iowa Women's Archives. At the State Historical Society of Iowa in Iowa City, thanks to Mary Bennett and Matt Schaeffer in Special Collections and Linda Brown-Link, Paula Smith, and Kevin Knoot in the Library. Thanks also to the staffs at all the other collections listed in the Bibliography.

Thanks to my brothers and sisters in Christ at Washington Reformed Presbyterian Church and Westminster Orthodox Presbyterian Church for providing communities in which my family could find a home. Special thanks to Dorothy Jarrard, Rob and Dorcas Jarrard, Lorna Olson, Greg and Nancy Skubal, Matt and Shana Anema, Casey and Jennifer Bessette, and Jason and Cindy Stewart for being such good friends.

Thanks to my parents, Charlie and Joan Fry, for all their encouragement. They never doubted my ability to finish the dissertation or the book. Thanks to my immediate family for being a necessary bit of reality in the midst of the sometimes unreal academic existence. Thank you, Deborah Joan, Stephen Paul, Benjamin Charles, and Daniel John, for loving me unconditionally and for being so excited when I came home from school each day.

It would be utterly impossible to describe everything my wife Paula has done to make this book possible. She moved hundreds of miles away from her family. She keeps our household running on the various sources of income a scholar receives. She does the lion's share of training up our children in the way they should go. She listens to me go on and on about subjects she really isn't interested in. She forces me to explain myself in words that the college-educated but non-historian can understand. She improves my work in dozens of small ways. She is my best friend and my only love. Thank you, Paula. You are my inspiration. 


\section{The Rural Midwest and the Farm Press During the Progressive Era}

In the late nineteenth and early twentieth centuries, economic, demographic, and cultural changes transformed American life, both rural and urban. During the 1870 s, the number of non-farm workers had surpassed the number of farm workers. In the $1880 \mathrm{~s}$, manufacturing surpassed agriculture as the principal source of wealth in America. Cities grew, their numbers swelled by immigration from Eastern and Southern Europe. Urban culture diverged from that of the countryside. Walter Nugent described the years between 1870 and 1920 as a "great conjuncture" when rural and urban ways of life competed for supremacy. Richard Hofstadter noted that "the United States was born in the country and moved to the city."

Hal Barron described these changes as a "second great transformation" in the economy and society of the United States. This transformation of American life consisted of several elements. Industrialization and consolidation of large corporations created a class of managers that rationalized production for maximum efficiency. A new middle class of professionals sought to remake government and social institutions. New forms of print culture and consumer advertising sold the products of industrial capitalism. While some historians have described these processes as the irresistible forces of modernization, Barron argues persuasively that there were multiple paths to modernity and that the processes were frequently incomplete, especially among country people. ${ }^{2}$

These cultural, economic, and demographic dislocations caused anxiety in many Americans, whether they lived in the country, in towns, or in cities. A variety of groups and individuals inaugurated social reform movements to deal with change. Reformers came to be called "Progressives"and the period the Progressive Era-because they talked of progress and 
were oriented toward the future. They founded settlement houses to integrate immigrants into American society, led campaigns for more effective government, and called for significant changes to the educational system. Some even turned their eyes toward the countryside, hoping to make farmers more efficient and to bring rural ways of life up to their standards. Rural reformers came to be called Country Life reformers; their program for rural change was the Country Life movement.

Country Life reformers were responding to the dramatic changes that rural America experienced between 1895 and $1920 .^{3}$ As cheap land dwindled, farmers adopted more capital-intensive agricultural methods, such as the use of fertilizer, silos, additional machinery, and better livestock breeds. These years were prosperous ones for many farmers and other country people. High prices for both farmland and farm commodities provided rural Midwesterners with new opportunities to decrease their cultural isolation. Farmers first installed telephones in the 1890s, and rural free mail delivery was nearly universal by 1910 . Federal parcel post delivery brought all kinds of new consumer products into rural homes during the 1910s. Automobiles were widespread by 1920 . These developments generated great optimism in rural communities; country people were finally able to share many of the amenities town and city people enjoyed. That optimism was mixed with uneasiness, however, for the migration of rural Midwesterners to towns and cities had become unmistakable by 1910 . Even as farm life was improving, many country people were leaving the farm. ${ }^{4}$

Reformers offered recommendations about both farming methods and rural ways of life. Historians have characterized the relationship of country people to early twentieth century reform movements in several different ways. During the 1960s and 1970s, modernization theory in sociology led historians to view these changes as the inevitable modernization of rural America. ${ }^{5}$ These historians depicted Progressivism and the Country Life Movement as the forces of modernity, bringing modern ways of farming and living to rural areas. They described country people as eagerly embracing these reforms or at least as being swept along with the tide. Agricultural historians of the 1970s embraced the contrasting theme of resistance to modernity. The two major studies of the Country Life Movement depicted farmers as resisting most of the Country Life program. ${ }^{6}$ In the end, however, both of these books argue that country people were forced to accept the changes wrought by modernity. In contrast, recent works of the "new rural history" have emphasized that country people did not only resist change. Instead, rural Americans adopted new practices selectively and adapted them so that they complemented traditional goals and ways of life. New Rural Historians 
depict rural life as a rich tapestry, shaped by thousands of different individual choices and ways of dealing with new ideas and realities. ${ }^{7}$

This book will explore these changes, the recommendations of reformers, and the reactions of country people by examining the history of the Midwestern farm press between 1895 and 1920. Farm newspapers were important to the lives of many country people. A 1913 survey by the United States Department of Agriculture revealed that many more farmers received farm newspapers than received government agricultural bulletins, attended farmers' institutes, or made use of a government agricultural demonstration agent. The report of the survey concluded that "the agricultural press would seem to be at present the most efficient of our agricultural extension agencies in reaching the farmer." 8 It probably was. Journalism researchers have estimated that the total circulation of farm newspapers nationwide exceeded seventeen million in 1920. That year the farm population of the U. S. was only thirty-one and a half million. ${ }^{9}$ Farm newspapers participated in the debate over progress in agriculture and rural life. Their presence in the homes of so many farm people suggests that they played a role in the "second great transformation." This book seeks to understand that role.

Historians have given conflicting depictions of the farm press. Many histories of the farm press itself, most written in the first half of the twentieth century, assert that the farm newspaper was a major cause of changes in agricultural methods during the entire nineteenth and early twentieth century. They depict farm newspapers triumphantly, as convincing farmers to adopt progressive agricultural methods. These works do not produce much evidence linking farm newspapers directly to changes in agriculture. Instead, they merely connect the simultaneous rise of the farm press and new agricultural methods. ${ }^{10}$

More recent works of the "new rural history" use farm newspapers in a different way. Interested in the changes that came to rural life in the late nineteenth and early twentieth centuries, rural historians use farm newspapers as evidence for these changes. Historians also consult the farm press to determine the attitudes of farmers toward these changes. Unfortunately, many of these works do not confront the nature of this evidence directly. ${ }^{11}$ Scholars depict farm newspapers as the mouthpieces of farmers in general, or wealthy farmers, or agricultural reformers, or urban interests, or some other group. Historians have argued both that farm newspapers merely reported change in the countryside and that they sought to influence it. As one rural historian has noted, "Sometimes we use farm newspapers only when they support the argument we're trying to make." 12 The nature and position of the farm newspaper needs to be determined more carefully. 
This book will attempt to answer such questions as: Why did farm newspapers become so numerous and popular between 1895 and 1920? What were the characteristics of the editors and publishers of these papers? What were rural Midwesterners reading during the period? Who were the readers of farm newspapers? What relationship did the papers, their staffs, and their readers have to the social reform movements of the Progressive era? The book presents an examination of the papers themselves, their editors and publishers, and their readers. This analysis sheds light on interactions between the farm press and Progressive social reformers, between the farm press and country people, and between country people and social reformers. It broadens and deepens our understanding of change in the countryside at the turn of the twentieth century. Finally, it suggests guidelines for historians who use farm newspapers as sources for rural history.

This project examines farm newspapers between 1895 and 1920 . The period opened with agriculture in the midst of a depression. During 1895, the Populist Party was making inroads in the South, Great Plains, and northern Middle West. Also in this year, James M. Pierce, publisher of the Iowa Homestead, fired his editor, Henry Wallace. At the time, the Homestead was the most popular general farm newspaper for lowa and its surrounding states. Shortly after his dismissal, Wallace joined two of his sons in publishing a rival farm paper that eventually became Wallaces' Farmer. Competition between the two papers resulted in a high percentage of Iowans and other Midwesterners receiving one or both farm newspapers within the next twenty-five years. For these reasons it is appropriate to begin this examination in 1895 .

Prosperity returned to agriculture after the election of 1896 . The years from 1896 to 1920 are often called the "Golden Age" of American agriculture. During these years, prices for agricultural commodities were high enough to allow many farmers to have a comfortable standard of living. Progressive and Country Life reformers took advantage of these years of rural prosperity to advance their program for the reshaping of rural life. ${ }^{13}$

The Country Life Movement was led by urban-based educators, religious leaders, and social scientists concerned about the future of farm life in the United States. Professors at agricultural colleges, employees of the United States Department of Agriculture, and editors of rural and agricultural newspapers attempted to reach country people with a new vision of country life. They hoped to apply Progressive urban reforms to rural areas. In August of 1908, President Theodore Roosevelt appointed the Commission on Country Life. The seven men appointed to the commission (one of whom was Henry Wallace, the editor of Wallaces' Farmer) talked 
with country people in meetings held across the country that fall. They also tallied the responses from over one hundred thousand questionnaires about the nature and problems of farming and rural life. The Commission presented its report to the president early in 1909. The Report of the Country Life Commission gave form and organization to ideas that had been put forward by reformers since the turn of the century. ${ }^{14}$

The Report described many farmers as prosperous, healthy, and happy, but it also identified a number of problems with both agriculture and rural life. The authors argued that some farmers were using agricultural practices that robbed their soil of its fertility. Furthermore, most farmers were at the mercy of large organized interests, such as meat packers, grain dealers, and especially railroads. Farmers needed to organize to protect their interests, to take steps to preserve soil fertility, and to grow crops more efficiently. The Commission, however, saw a reorganization of rural life as more important than a reorganization of rural agriculture. Traditional social institutions such as the rural family, rural school, and rural church had fallen behind the times. These institutions no longer provided for a satisfying life in the country, and therefore farmers had begun to leave rural areas for towns or the city. ${ }^{15}$

Between 1909 and 1920, reformers became more active and insistent in their calls for the reform of rural life. Country Life leaders held conferences, published books, and enlisted both government bureaucrats and newspaper journalists to take their message to country people. Academics at agricultural colleges and universities performed rural sociological studies to discover the health or pathology of rural communities. Finally, some reformers promoted legislation to benefit country people-or to force them to change. ${ }^{16}$

Characterizing Country Life reformers is difficult. Overall, Country Life leaders promoted a number of reforms, but many individual reformers chose several reforms for support and excluded others from their agenda. As a result, historians disagree on the best way to describe the movement. David Danbom and Mary Neth depict them as urban-based reformers who worked for the modernization of rural life. They assert that Country Life leaders were most interested in making agriculture and rural ways of living more efficient. William Bowers describes Country Life reformers as men and women who had grown up on farms but now lived in towns and cities. Because of their rural roots, they hoped to preserve the rural communities in which they grew up. David Reynolds agrees with Bowers that reformers were born in the country, but he asserts that the kinds of communities they promoted were deliberately different than the ones in which they grew up. 
Reynolds argues that Country Lifers hoped to create a new kind of community in the open country, one that provided all the advantages of living in the city. Paul Theobald and Grant McConnell see the Country Life Movement mainly as an effort to discipline farmers and to keep them from joining urban laborers in the fight against industrial capitalism. ${ }^{17}$

In my understanding, Country Life reformers were concerned about the quality of life in the country for two reasons. First, since most rural social reformers lived in cities, they were aware of the rising price of food during the early twentieth century. They believed that the high cost of living during those years was caused by inefficient farming methods, decreasing rural population, and increasing urban population. These reformers saw farming as a business enterprise and called for greater efficiency through scientific methods and mechanization. They advocated an industrialization of the countryside to bring it into line with modern standards. In this respect, I agree with Danbom and Neth; such Country Life leaders were primarily concerned with urban issues when they called for changes in agricultural methods.

Country Life leaders were also alarmed by the migration of many farmers' children to towns and cities, however. Reformers worried that the brightest and best were leaving rural areas. This branch of the movement saw farming as a way of life and used traditional agrarian language to argue that farm life was superior to city life. Bowers and Reynolds are right to point out that Country Life reformers had origins in the countryside and felt that rural communities must be preserved. Ironically, that the methods they advocated to preserve rural lifestyles and society often meant making that way of life more like life in the city. Such solutions included the introduction of labor saving devices, new organizations for farmers, and the remaking of rural social institutions.

It is reformers' treatment of these rural social institutions that caused the most controversy among country people. Reformers made pointed recommendations concerning the rural church, the country school, and the farm family. Farm newspapers were involved in the transmission of these ideas to rural Midwesterners. The final chapters of this book will address the ways that farm papers communicated these ideas between 1895 and 1920 .

The study closes in 1920, a year of transition for the United States, for the nation's farmers, and for the Midwestern farm press. The Great War dealt a severe blow to Progressivism. As one historian has observed, "Progressivism had always had the potential to be coercive, and in the context of World War One, it was coercive, in ways that were not progressive, not uplifting." 18 After the war, many Americans desired a "Return to Normalcy," meaning a 
retreat from Progressivism and federal government activism. Republican presidents provided this retreat during the 1920s. Rural areas of the country also entered another depression in 1920 . While commodity prices had remained high for several months after the end of the First World War, they fell precipitously in the middle of the year and stayed low for the next twenty years. While the transformation of rural life had not ended, the period marked by Progressive and Country Life reform had. As if to seal the end of an era for Midwestern farmers, in 1920 James M. Pierce died, leaving ownership of the Iowa Homestead in the hands of his son. This study of farm newspapers, reading, and rural reform concludes at the end of this pivotal year.

According to most historians of the farm press, the American Farmer, first published in Baltimore in 1819, was the first American farm newspaper. The number of farm newspapers nationwide increased rapidly to about sixty in 1860 , about one hundred and fifty in 1880 , about three hundred in 1895 , and about four hundred in 1920 . They were normally published in larger towns or cities surrounded by a significant agricultural population. Papers were generally printed once a week or once a month, although some were published semi-monthly and a handful came out daily. The cost of a subscription was between fifty cents and four dollars a year; most weeklies cost about one dollar a year at the turn of the twentieth century. ${ }^{19}$

James Evans and Rodolfo Salcedo, journalism researchers at Iowa State University in the early 1970 s, used the term "commercial farm periodical" to refer to a publication that "is directed to farmers and supports itself through the sale of subscriptions and/or advertising." 20 I will apply their definition to the term "farm newspaper." The definition encompasses local, regional, and national farm newspapers. It does not include small-town or rural newspapers, because their purpose was generally to report local and national news, not to provide information about farming to farmers. ${ }^{21} \mathrm{It}$ also does not include the late nineteenth century Midwestern and Great Plains "reform press." The reform press consisted of newspapers that called for political change. While many were published in small towns or rural areas, their orientation was primarily political, not agricultural. ${ }^{22}$ Finally, the definition does not include government publications, publications of agricultural colleges or experiment stations, or publications by farm businesses that advertised the products of only one business. The farm press itself and historians of the farm press have used various names in referring to the farm newspaper in the nineteenth and early twentieth centuries. This project will use the following terms interchangeably: farm newspaper, agricultural newspaper, farm press, and agricultural press. 
By the turn of the twentieth century, farm newspapers could be categorized in several ways. One way is by the region served: while some farm newspapers aspired to national prominence, such as The Country Gentleman and Successful Farming, most existed to serve a region or state. The Prairie Farmer served the Midwestern corn belt, the Southern Cultivator the cotton-growing south, and Moore's Rural New Yorker rural New York and New England. A second categorization is by amount of specialization: some farm newspapers addressed farming and rural life in general, while others specialized in one type of farming, such as stock raising, dairying, or horticulture. The papers listed above were all general farm newspapers; The Farmer and Breeder is an example of a livestock journal, Hoard's Dairyman a dairy paper, and the American Horticulturalist a horticultural paper. These divisions were visible at the time. The editor of Wallaces' Farmer, described them using similar categories:

[Some farm newspapers] are devoted to specialties; for example dairy papers, and horticultural papers ... these are all valuable to the man who is engaged in that particular specialty.

There are others, and Wallaces' Farmer is prominent among them, that are devoted to the discussion of problems that interest the common farmer in a specified district. Wallaces' Farmer is not a paper of general circulation all over the United States. It don't [sic] know anything about cotton or tobacco growing, or the growing of the citrous [sic] fruits, or the trucking business. Its chosen field at first was Iowa, but so many farmers in outside states began to send in subscriptions that it enlarged that field to Iowa and the adjoining states... ${ }^{23}$

This book examines general farm newspapers aimed at a Midwestern regional audience. ${ }^{24}$

Regional histories were popular in the early twentieth century, but they fell out of favor with the rise of consensus histories in the 1950s. For many Americans, the aftermath of the Second World War and advent of the Cold War required a coherent national story. Since the 1980s, however, prompted by studies of the American West as a region, historians have taken a new interest in all regions of the United States. ${ }^{25}$ The Middle West has received its share of attention. A number of scholars argue that the Midwest as a region is worthy of study, especially during the Progressive Era, for it appears that the peak of Midwestern cultural influence occurred during the first twenty years of the twentieth century. Most recently, The American Midwest: Essays on Regional History provides a number of reflections on Midwestern contributions to American History. The editors' 


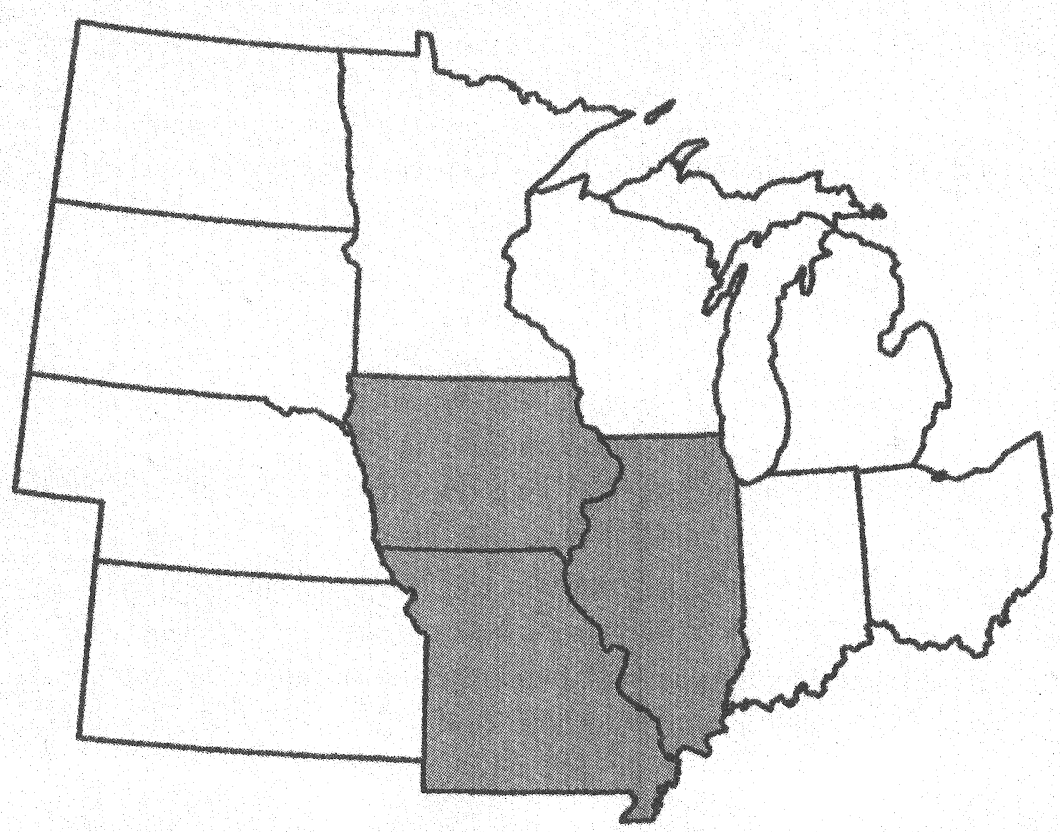

Map 1. The Lower Midwest

introductory essay provides a historiographical and bibliographic introduction to the region. ${ }^{26}$

I will examine the regional farm newspapers published in a subregion of the Midwest I call the "lower Midwest." 27 All of the farm newspapers studied were targeted at farmers in Iowa, Illinois, and Missouri. These three states form the center or crossroads of the Midwest (see Map 1). Letters to the editors of these papers came mainly from these three states, although many were from other states of the Midwest, and some were from outside the region. This subregion is large enough to allow me to make generalizations about the entire Midwest, yet small enough to allow me to analyze readership closely.

This study will focus on four farm newspapers published in the lower Midwest: the Iowa Homestead, Wallaces' Farmer, the Prairie Farmer, and the Missouri Ruralist. I have examined available issues from these newspapers between 1895 and 1920 . These four farm newspapers were among the most important and influential general farm newspapers in the Midwest during the period. In addition, they are appropriately typical for the questions to be asked in the analysis. ${ }^{28}$ All four were general farm newspapers, pub- 
lished weekly or semi-monthly in the lower Midwest. They are sufficiently similar to use them to draw conclusions about the Midwestern farm press. ${ }^{29}$ At the same time, the backgrounds of individual editors and publishers were different, and as a result the papers took slightly different approaches to different issues. Therefore there is also sufficient diversity to compare the papers' character and personnel. Finally, most of the issues from the period have survived, either in hardcopy or microfilm.

Chapter one will address the farm newspapers themselves. What were farm papers like at the turn of the twentieth century? How did they change between 1895 and 1920? During the period, Midwestern general farm newspapers experienced expansion and change in their circulation, content, and advertising. This chapter will give the organizational histories of the four papers examined, noting their similarities and differences. It will also consider how farm newspapers paid for their operations, reached out to new subscribers, and sought to satisfy current readers. Finally, it will consider Midwestern regional farm newspapers' intended audience.

In chapter two, we turn our attention to the editors and publishers of farm newspapers. Who owned farm newspapers? Who edited them? Where did they live? Who did they identify with? This chapter will address the producers' locality (urban versus rural), occupation, and class. It will give the biographies of the editors and publishers of the four farm newspapers examined and evaluate whether their identities were more like those of their readers or the urban social reformers who addressed those readers. ${ }^{30}$

The next two chapters deal with the readership of Midwestern farm newspapers. A study of the readers of farm newspapers is best done in the context of what country people in the Midwest were reading at the turn of the twentieth century. Chapter three presents a preliminary investigation into the general reading habits of rural Midwesterners. It reports the results of research in letters, diaries, account books, and other sources from Midwestern farm families. My research suggests that country people read an eclectic mix of local newspapers, farm newspapers, magazines, and books.

Chapter four completes my investigation of readership by considering the rural Midwesterners that received and read farm newspapers. United States Department of Agriculture researchers and rural sociologists compiled information about the readership of farm newspapers in the reports of their rural social surveys. This chapter also analyzes a subscription list for Wallaces' Farmer in Story County, Iowa. It concludes by considering the biographies of several rural Midwesterners who subscribed to agricultural newspapers at the turn of the century. Farm newspaper readers owned varied amounts of wealth and occupied diverse situations. 
With chapter five, we turn from an examination of the individuals involved in farm newspaper publication and circulation-publishers, editors, and readers - to an investigation of how these groups interacted. All four papers published recommendations about how to improve rural life and keep country people in the country. Many of these recommendations had to do with reforming important rural institutions: the family, religion, and education. As one author put it in the Missouri Ruralist, "The youth of the rural districts have been educated to leave the farm and three great institutions are responsible: 'the school, the church and the home." 31 The last chapters of the dissertation examine farm newspapers' coverage of social reforms in these three areas.

While the rural church was a very important feature of rural Midwesterners' lives, religion has often been ignored in many histories of rural America, as it has been in many broader narratives of United States history. For instance, David Danbom's excellent narrative of American rural history, Born in the Country, addresses rural churches only briefly. And while Hal Barron's Mixed Harvest introduces each chapter with a quote from the Bible, his text does not mention religion at all. Recently, a number of historians have challenged their colleagues to talk more about the influence of religion on American history, both in their research and in their teaching. ${ }^{32}$ Chapter five seeks to answer the challenge by examining the treatment of the rural church in Midwestern farm newspapers. It will consider how much Progressive social reformers influenced farm papers' treatment and how rural Midwesterners responded to these recommendations.

The neighborhood one-room school was another vital institution for Midwestern rural life in the late nineteenth and early twentieth centuries. Like the rural church, the rural school was targeted for reform by Progressive reformers. Chapter six addresses farm newspapers' recommendations concerning the rural school. It considers the recommendations made by general farm newspapers in the Midwest, both about the curriculum and the organization of rural schools. It also surveys the responses of rural Midwesterners to farm papers' advice.

Finally, chapter seven considers the coverage of the rural family in Midwestern farm newspapers. Writers for farm papers were concerned that too many rural Midwesterners were leaving the farm and moving to towns and cities. They often blamed this exodus on the dissatisfaction of farmers' wives or children. Therefore, farm newspapers gave recommendations about the best ways to keep the farm family-and therefore the farmer-on the farm. As in the previous two chapters, this chapter will consider the advice given by farm papers and the responses of rural Midwesterners to that advice. 
The conclusion considers the many uses of farm newspapers. Country Life reformers used farm newspapers to spread their message of rural transformation, but readers of farm newspapers used them in a variety of ways. Farmers were not an unquestioning audience. The conclusion will also consider the uses that historians today can make of farm newspapers and offer suggestions for how best to read these publications.

For most of American history, country people have made up a majority of the population of the United States. Recent historians, often born and raised in urban areas and influenced by the great urban historians of the twentieth century, have often been more interested in the history of American cities. Many scholars have overlooked, downplayed, or even denigrated the history of rural America. Furthermore, too often historians have sought to make generalizations about all country people, often contrasting them with urban laborers. Farmers and their families were complex people, and they deserve a history that treats them as such. ${ }^{33}$ It is my hope that this book will contribute to the goals of the New Rural History as described by David Danbom: to return a voice to the rural majority, to provide a usable past to rural Midwesterners and their descendants, and to help historians to "represent the texture and complexity of the American past more accurately, and thus derive a clearer image of the American experience." 34 


\section{Chapter One}

\section{"First Class Papers" and "Never-Stop Papers": \\ Twenty-Five Years of the Midwestern Farm Press}

You will save yourself trouble, and in doing so contribute materially to advancing the cause of agriculture, and promote your own peace of mind, if you will refuse to subscribe for any paper which does not require payment in advance and distinctly pledge itself to stop when the time is out.

\section{-Henry Wallace, Editor, Wallaces' Farmer ${ }^{2}$}

Between 1895 and 1916, Henry Wallace, the editor of Wallaces' Farmer, devoted many of his editorials to the subject of farm newspapers themselves: their purpose, their possibilities, and their policies. In several, he divided farm newspapers into two classes based on subscription policy. Wallace was proud of the fact his paper required payment in advance and stopped sending issues when subscriptions ran out. He called other papers "never-stop papers," accusing them of not stopping when a subscription expired. They continued to send issues, then required payment and even turned subscribers over to collection agencies for not paying. A number of his editorials gave instructions on how to stop receiving such papers, including what to say in a letter to the publisher and when to notify the local postmaster to refuse future issues. Wallace contrasted such papers to "first-class papers" that provided quality editorial matter and expected subscribers to pay for it. ${ }^{3}$

The years between 1895 and 1920 were prosperous years for all kinds of farm newspapers. The agricultural economy boomed, and agricultural journalism benefited from this growth. Farm newspapers across the country increased both the number of pages printed and the number of copies sold. ${ }^{4}$ 
In content, advertising, and circulation, Midwestern farm newspapers expanded and changed between 1895 and 1920. This chapter will first provide an overall description of United States farm newspaper publication and distribution. It will then give brief narrative histories of the four farm newspapers examined. Finally, it will consider the characteristics of these four farm newspapers in the areas of circulation, content, and advertising, noting how they changed over time. These observations will draw a picture of farm newspapers in the lower Midwest during the late nineteenth and early twentieth centuries. ${ }^{5}$

\section{THE AGRICULTURAL PRESS IN THE UNITED STATES, 1895-1920}

Historians of agricultural journalism have described both expansion and change in the farm press between 1895 and 1920. In general, farm newspapers grew in number, circulation, and number of pages during the period. Agricultural journalism also began a long process of business consolidation. Finally, farm newspapers slowly changed in their relationship to other sources of information.

Journalism researchers James F. Evans and Rodolfo N. Salcedo describe the remarkable growth of farm newspapers between 1895 and 1920 . The number of farm newspapers increased by a third from 303 in 1895 to 405 in 1920 . The number published in the Midwest grew by almost half, from 139 to 195 . Actually, many more than fifty-six began publication during the period; a large number also went out of business or were bought or merged with existing papers. Circulation nationwide tripled from five and a half million to seventeen million subscribers. Evans and Salcedo estimate that in 1895, the average U. S. farm received 1.06 farm newspapers, while in 1920, the average farm received 2.65. Finally, between 1890 and 1919 , all farm newspapers' salaries and wages increased from $\$ 69$ million to $\$ 288$ million, their cost of materials increased from $\$ 39$ million to $\$ 300$ million, and the total value of their products increased from $\$ 180$ million to $\$ 924$ million. All of these figures paint a picture of incredible expansion. ${ }^{6}$

The growth of farm newspapers was partially due to circumstances external to the agricultural press itself. The nation's economy, in the doldrums for much of the 1880 s and 1890 s, soared during the first twenty years of the new century. Agriculture expanded between 1895 and 1920 as white Americans and European immigrants settled land newly taken from Native American peoples in the West. The number of farms nationwide reached 6.5 million in 1920, and the number of acres in farms increased from 536 million acres in 1880 to nearly 956 million acres in 1920. Total 
farm employment peaked in 1916 at 13.6 million; it has dropped ever since. Such growth in the number of both farms and farmers meant a much larger market for agricultural publications. ${ }^{7}$

Farm newspapers actively reached out to possible readers throughout the period. Most of the efforts at gaining additional subscribers were conducted during the winter months, when the tide of agricultural labor had ebbed. Farmers had less outside work and more time to read and consider what subscriptions to purchase for the following year. Farm newspapers printed calls for readers to renew their subscription each December and sent out renewal notices during that month. ${ }^{8}$ From December to March, papers trumpeted their low prices, club arrangements and premiums. Winter was also the time of year that paid subscription agents worked hardest. Jack Van Derhoof lists nine different ways in which farm papers attracted new subscribers in the late nineteenth century: sample copy distribution, reduced prices for group subscriptions, dual subscription clubs, premiums, sales agents, support of agricultural fairs, advertising in other papers, special order blanks, and providing a good product. ${ }^{9}$ Thus, while increased circulation can be partially attributed to an expanding market, farm newspaper staffs worked hard to tap that market. They attempted to persuade those who had not received a farm paper to purchase theirs and to convince subscribers of rival papers to switch or add a subscription to their paper.

In addition to expanding their operations, farm newspapers also changed in ownership and content during the period. During the early twentieth century, the farm press entered a period of consolidation that has continued to the present. Changes in ownership and mergers had been a feature of the agricultural press since its earliest years. During the nineteenth century, most mergers resulted in the absorption of one paper. After 1900, however, individuals began to buy and publish more than one paper. James M. Pierce, Arthur Capper, and others bought multiple papers in several regions and continued to publish them in varying degrees of independence from each other. While the number of farm newspapers continued to increase until 1920, the ownership of those papers began to be consolidated in fewer hands.

Finally, farm newspapers' content changed as they increasingly came into competition with new sources of agricultural information. Colleges of Agriculture ran short courses, conducted experiments, and issued regular bulletins. State Departments of Agriculture and the United States Department of Agriculture (U. S. D. A.) issued regulations, gathered statistics, funded experiments, and published reports. Farmers' organizations, such as county agricultural societies and farmers' institutes, sponsored fairs 
and short courses where papers were presented. These institutions furnished additional material for farm newspapers, which often reprinted their speeches and publications. ${ }^{10}$

Jack Van Derhoof argues that these new sources of content changed the role of the farm editor. During the first fifty years of agricultural journalism (1819-1869), he asserts, the farm newspaper editor served as an autocrat, a writer whose main job was to tell his audience what to believe and do. The farm editor drew on his personal experience to answer questions and make pronouncements on the right way to farm. These were personal papers, where editors and publishers talked about what was going on in their own lives and on their own farms. After the 1870s, Van Derhoof argues, the era of "personal journalism" was over. Farm editors became information conduits, rather than information sources. The editor's role was less to push his ideas and more to bring the farmer into contact with a number of different ideas from other sources of agricultural information. In general, he asserts the farm editors of the 1880 s and 1890 s were significantly different than those of early farm journalism. ${ }^{11}$

Thus, previous historians have outlined both the growth and changes that came to the American agricultural press between 1895 and 1920. Farm newspapers grew immensely in size, number, and circulation, and their patterns of ownership and content changed significantly. Did the Midwestern farm press share these trends? The next section examines four farm newspapers in terms of these categories.

\section{FOUR MIDWESTERN FARM NEWSPAPERS}

The years between 1895 and 1920 were years of expansion and change for the Midwestern farm newspaper, as they were for the farm press in general. All four of the newspapers examined increased their circulation during the period (See Table 1). Unfortunately, circulation figures before the 1910 s are not completely reliable because no one regularly policed publishers' claims. Tales of overstated circulation figures are common. In 1914, however, advertisers and publishers formed the Audit Bureau of Circulations. Within several years, the Audit Bureau was actively auditing publishers' reports, resulting in the revision downward of some publications' circulation numbers. ${ }^{12}$ Still, while the actual figures may be inaccurate, it is clear that circulation skyrocketed between 1895 and 1920.

This section provides an introduction to the four newspapers studied: the Iowa Homestead, the Prairie Farmer, Wallaces' Farmer, and the Missouri Ruralist. It will consider their history, owners, editors, size, and circulation. 
The Iowa Homestead had a long publishing history in Iowa. Its earliest predecessors were published in several different Iowa towns between 1853 and 1862. In 1862, Mark Miller bought the last of these, the Pioneer Farmer of Des Moines, and renamed it the Iowa Homestead and Northwestern Farmer. Miller was a New Hampshire farmer who had moved to Wisconsin and to Des Moines in 1862 . He owned the Homestead until 1864 and edited it until 1868. Between 1868 and 1885, the paper was sold numerous times, had many editors, and was published under a variety of names. ${ }^{13}$

In the 1880 s, however, ownership and editorship stabilized. In 1880, the name was shortened to Iowa Homestead. In 1883, Henry Wallace, a Presbyterian minister and farm manager in Winterset, Iowa, became the

Table 1. Circulation Figures for Selected Midwestern Farm Newspapers

\begin{tabular}{|c|c|c|c|c|}
\hline Year & $\begin{array}{l}\text { Iowa } \\
\text { Homestead }\end{array}$ & $\begin{array}{l}\text { Missouri } \\
\text { Ruralist }\end{array}$ & $\begin{array}{l}\text { Prairie } \\
\text { Farmer }\end{array}$ & $\begin{array}{l}\text { Wallaces } \\
\text { Farmer' }\end{array}$ \\
\hline 1895 & 30,000 & n. p. & 25,000 & $7,500^{*}$ \\
\hline 1900 & 40,076 & n. p. & 25,000 & 23,769 \\
\hline 1905 & 60,000 & 5,000 & 25,000 & 37,389 \\
\hline 1910 & 100,000 & 10,500 & 42,052 & 54,006 \\
\hline 1915 & 148,312 & 54,991 & 89,088 & 72,000 \\
\hline 1920 & $138,194^{+, \#}$ & $90,042^{+}$ & $112,128^{+}$ & $65,200^{+, \#}$ \\
\hline
\end{tabular}

\begin{tabular}{|c|c|c|}
\hline \multirow[t]{6}{*}{ Key: } & n. p. & Not published \\
\hline & bold & Sworn statement \\
\hline & plain & Publisher's claim, unsupported by affidavit \\
\hline & * & $\begin{array}{l}\text { Figure for The Farm and Dairy, published at Ames } \\
\text { by Henry C. Wallace and John P. Wallace }\end{array}$ \\
\hline & + & Statement audited by Audit Bureau of Circulations \\
\hline & \# & $\begin{array}{l}\text { It is likely that the publishers of these papers overstated } \\
\text { their circulation in the 1910s, and that the work of the Audit } \\
\text { Bureau of Circulations (created in } 1914 \text { and auditing circulation } \\
\text { figures by 1920) revised their figures downward, not that they } \\
\text { lost subscribers between } 1915 \text { and } 1920 \text {. }\end{array}$ \\
\hline
\end{tabular}

Source: N. W. Ayer \&o Son's American Newspaper Annual (Philadelphia: N. W. Ayer \& Son, 1895, 1900, 1905, 1910, 1915, 1920). 
paper's editor. Two years later, James M. Pierce, the publisher of several newspapers in small towns in Missouri and Iowa, bought the paper. Under their joint leadership, the paper added subscribers across Iowa and in many surrounding states.

In 1894, Wallace and Pierce quarreled over the paper's editorial policy towards corporations. Wallace's editorials sharply criticized railroads, grain elevators, and other companies he saw as opposing farmers' interests. Pierce thought that Wallace should be less harsh and refused to print several editorials. Wallace made it known that he believed Pierce just wanted to keep advertising revenue coming in from such companies. The power struggle continued until Pierce fired Wallace early in $1895 .^{14}$

When Henry Wallace left the Homestead, it was a weekly that averaged twenty-four pages each week. During summer months an issue was normally sixteen pages long, and during the winter it was often thirty-two. The subscription price was one dollar a year. N. W. Ayer \& Son's American Newspaper Annual (hereafter Ayer) listed its circulation as thirty thousand. It appears that after Wallace's departure, the paper was edited by S. F. Stewart, Pierce's lawyer and partner in the operation of the paper, although the masthead and other sources do not list an editor until 1905. ${ }^{15}$

The paper grew in both circulation and size over the next ten years. According to Ayer's directory, the Homestead's circulation doubled between 1895 and 1905. During 1905, the paper printed 1948 total pages, for an average of about thirty-eight pages per issue. In the September 14 issue of that year, the masthead listed an editor for the first time since Henry Wallace's departure: "James Atkinson, Editor-in-Chief." Atkinson had most likely been with the Homestead starting in 1901 or $1902 .{ }^{16}$

By 1920, the Homestead printed more pages per issue and sent them to more subscribers than any of the other Midwestern farm newspapers studied. Its circulation was almost one hundred forty thousand, more than twice as many as its main competitor in Iowa. The paper printed 3,444 pages that year for an average of sixty-six pages per issue; issues of over one hundred pages in the winter balanced issues of forty-eight pages in the summer. The subscription price remained at one dollar per year. Editor James Atkinson left the paper to work for the United States Department of Agriculture in 1918 and was replaced by John Thompson. James M. Pierce died November 1, 1920. He had devoted thirty-five years of his life to the paper. His son Dante M. Pierce took control of the organization. ${ }^{17}$

Like the Homestead, the Prairie Farmer already had a long publishing history in 1895. It was the first farm newspaper published in Illinois and, in its early years, the most important farm paper in the state. The Union 
Agricultural Society of five northern Illinois counties created the paper in 1840 as the Union Agriculturalist and Western Prairie Farmer. Three years later, the Society sold the publication to its editor, John Stephen Wright, who shortened the name to Prairie Farmer. Wright owned and edited the paper until the Panic of 1857, when debts forced him to sell the paper to his printers. ${ }^{18}$

The staff of the Prairie Farmer in the mid-twentieth century commonly called the years between 1857 and 1908 "the middle years." ${ }^{19}$ These years were marked by frequent changes in ownership and reversals of fortune, much like those experienced by the Homestead. The paper enjoyed huge success during the decade of the Civil War, when owner Harry D. Emery and editors Charles D. Bragdon and William W. Corbett turned out a paper with high quality editorial matter to a large circulation. Unfortunately, three events during the next decade crippled the newspaper: the Chicago fire of 1871, the Panic of 1873, and the collapse of several of Emery's business ventures. In 1882, Emery sold the paper to Rand McNally and Company of Chicago. In 1884, Orange Judd, the former editor of the popular national farm newspaper American Agriculturalist, was employed as editor in the hopes of turning the publication around. Judd increased the paper's quality and circulation, but both declined when he left in $1888 .^{20}$

Between 1889 and 1905, there was no editor listed in the masthead, but later articles in the paper stated that Jonathan Perriam was editor from 1889 to 1903 and James J. Edgerton edited the paper from 1903 to $1905 .{ }^{21}$ Notwithstanding these changes in editorship, the paper itself remained much the same. Every year between 1895 and 1905, Rand McNally published fifty-two sixteen-page papers and sold them for one dollar a year to about twenty-five thousand subscribers. Articles and editorials were almost exclusively devoted to farm subjects, and there was a significant amount of advertising. Jack Van Derhoof suggested that "Rand McNally was more interested in furthering the sale of maps than in solid agricultural material."22

Chauncey P. Reynolds became editor in March of 1905 and served until his death late in 1910 . During his editorship, the paper changed its frequency from weekly to semi-monthly and lowered its subscription price to thirty-five cents a year. ${ }^{23}$ More significant changes in content and format, however, came with Burridge D. Butler's purchase of the paper in 1909 and his hiring of Clifford V. Gregory to be the editor two years later. Under their leadership, the paper grew dramatically in both size and circulation. In 1915 the paper went from semi-monthly to bi-weekly publication, and in 1919 it returned to weekly publication. In 1920, it printed 2762 pages, an average 
of fifty-three pages a week. The subscription price was eighty-five cents a year, and the paper was sent to over one hundred thousand subscribers. Its circulation was second only to the Homestead among the Midwestern farm newspapers studied. ${ }^{24}$

Wallaces' Farmer had a much more stable ownership and editorship history than the Prairie Farmer. After leaving the Homestead early in 1895, Henry Wallace went into business with his sons Henry C. Wallace and John P. Wallace, who were publishing a semi-monthly farm newspaper called Farm and Dairy in Ames, Iowa. On March 1, 1895, the first issue of Wallace's Farm and Dairy was published with Henry Wallace as editor. Later that year, the Wallaces opened an editorial office in Des Moines, increased the paper's frequency to weekly, and changed its name to Wallaces' Farmer and Dairyman. During the first month of 1896 , the entire operation was moved from Ames to Des Moines. ${ }^{25}$ In the December 9 issue of 1898, the title was simplified to Wallaces' Farmer. That issue also debuted the motto that has been used ever since: "Good Farming-Clear Thinking-Right Living." 26 Between 1895 and 1900, the circulation of the paper more than tripled from seventy-five hundred to almost twenty-four thousand. During 1900 , the paper provided thirteen hundred pages to subscribers for the one dollar a year subscription price. ${ }^{27}$

The paper continued to grow for the next twenty years, though it never matched the Homestead in either number of pages or circulation. In 1920, Wallaces' Farmer printed 2,898 pages, averaging fifty-six pages an issue. Its subscription price remained one dollar for a year. Its circulation had grown to just below seventy thousand. Henry Wallace edited the paper until his death in 1916, when the paper was continued under the editorial leadership of his son, Henry C. Wallace and his grandson, Henry A. Wallace. Henry C. became Secretary of Agriculture from 1921 to 1924. Henry A. Wallace became Franklin Delano Roosevelt's Secretary of Agriculture and Vice President, and ran for President on the Progressive Party ticket in 1948. In terms of editorial voice and policy decisions during the 1910s, however, the paper did not depart significantly from the direction set by the first Henry Wallace. ${ }^{28}$

The Missouri Ruralist was a newcomer to agricultural journalism in the early twentieth century. Matthew V. Carroll founded The Ruralist in Sedalia, Missouri in 1902; the first issue appeared on October 16. Carroll both owned and edited the paper from 1902 to 1910 . He and the paper's business manager, W. E. Hurlbut, together built the fledgling farm paper's circulation from nothing to over ten thousand in eight years. The paper printed between sixteen and twenty-four pages each week between 1902 
and 1910 . The subscription price was fifty cents a year until 1908 when it increased to a dollar a year. ${ }^{29}$

In June of 1910, Arthur Capper bought The Ruralist. Capper was a Kansas newspaper publisher who by 1920 owned farm newspapers covering an area from Kansas to Pennsylvania. Shortly after the purchase, Capper renamed it the Missouri Ruralist. Later that year he purchased the Breeder's Special of Kansas City and combined it with the Ruralist. Capper bought out Carroll and turned the paper over to the editor of the Breeder's Special. As a result the Ruralist's operations were moved to Kansas City. During the next three years, the publication had three different editors as Capper searched for the right man to lead the paper. The search ended in 1913 when Capper chose John Francis Case to edit the paper. Case remained editor of the Missouri Ruralist until 1955. ${ }^{30}$

The paper's circulation took off under Capper's ownership. Around ten thousand in 1910, its subscription list increased five-fold in the next five years and nine-fold in the next ten years. The paper cut back to semimonthly publication shortly after Case became editor in 1913. At the same time the subscription price was returned to fifty cents a year. In 1920, the paper printed over one thousand pages, as summer issues averaged thirtytwo pages and winter issues twice that. By 1920, the Missouri Ruralist was an established farm newspaper whose circulation exceeded that of Wallaces' Farmer and approached one hundred thousand. ${ }^{31}$

All four Midwestern farm newspapers underwent significant growth in both number of pages printed and number of copies sold between 1895 and 1920. They also all emerged from a period of instability in leadership to be led by dedicated publishers and editors. The backgrounds and outlooks of these men will be examined in more detail in chapter two. The character of the farm newspapers themselves is discussed in the next section.

\section{CHARACTERISTICS OF MIDWESTERN FARM NEWSPAPERS}

The Midwestern farm press expanded and changed in much the same ways that the farm press as a whole developed between 1895 and 1920. It appears that many of the observations made by historians concerning the farm press in general are applicable to the four farm newspapers studied. Increases in circulation were the result of economic prosperity and concerted efforts by farm papers to reach out to all farmers in their areas of coverage. Editorial content grew in size, and the papers became a forum for the discussion of rural life as well as agricultural methods. Finally, advertising in farm papers grew, and publications shifted from an exclusive reliance 
on farm-related product advertising to add a secondary reliance on consumer advertising.

\section{Circulation}

The farm newspapers in this study utilized most of the methods outlined by farm press historians to boost circulation. Subscription drives took place during winter months, as papers requested that subscribers renew their papers and made special offers to entice new readers. The most important methods used by the four Midwestern farm papers examined were low subscription prices, subscription clubs, premiums, contests, and paid agents.

One of the primary ways farm newspapers gained new subscribers was by low subscription prices. By 1890, most farm newspapers had shifted from a reliance on subscriptions for revenue to a reliance on advertising. Because higher circulation meant a paper could charge higher advertising rates, most papers kept the price of a year's subscription relatively low to increase circulation. By 1900, the cost of most weekly farm newspapers was about one dollar for one year. The four farm papers studied charged between thirty-five cents and one dollar for a year's subscription. It is likely that for the weeklies, this price was actually less than the cost of paper, printing, and postage, especially in the 1910 s when issues were over fifty pages long. Farm newspapers ran large advertisements and lengthy editorials trumpeting the value offered by low subscription rates. ${ }^{32}$

In addition, papers also occasionally offered special promotional rates. In the winter of 1904 the Ruralist accepted new subscriptions at twenty-five cents per year, and in 1906 it offered trial subscriptions of three months for ten cents. ${ }^{33}$ Papers also offered reduced rates for multiple-year subscriptions. While the Prairie Farmer was charging thirty-five cents a year for a subscription, it also offered four years for one dollar. In 1913, Wallaces' Farmer offered a three-year subscription for two dollars, a five-year subscription for three dollars, and a perpetual subscription for ten dollars. ${ }^{34}$ Thus, low subscription prices were a major way that farm newspapers reached out to new subscribers.

Agricultural newspapers also attracted subscribers through subscription clubs. Farm newspapers used the term "club" in two different ways. What I call the "group club" offered reduced rates when one person, usually called the "club-raiser," submitted several subscriptions. The club-raiser gathered the names of subscribers, collected their money and sent it in, and until the first years of the twentieth century, distributed the papers among members of the club. One can imagine these individuals visiting their neigh- 
bors weekly to deliver the papers and annually to collect subscription payments. By 1905, rural free delivery brought mail directly to most of the homes of the Midwest, so farm papers were sent directly to subscribers and the club-raiser was only responsible for signing up subscribers and collecting their money. Such clubs varied in size from two members to over one hundred. William H. Mills, a club-raiser for Wallaces' Farmer in the 1920s, compiled club lists that contained 194 unique subscribers. The club-raiser often received his paper free; the other members of the club paid reduced amounts for their subscriptions. ${ }^{35}$

The second arrangement that farm newspapers called a "club" may be called the "dual-subscription club." This arrangement offered an individual a subscription to the farm newspaper and to one or more other newspapers or magazines "at a price lower than the one paid if both were taken as separate subscriptions." 36 In 1897 a one-year subscription to the Prairie Farmer cost one dollar, and one year of the weekly Chicago Inter Ocean was also a dollar. The Prairie Farmer offered a subscription to both papers for one dollar and twenty-five cents. It offered such dual-subscription clubs for newspapers from Omaha, St. Paul, Kansas City, St. Louis, New York, and other cities. It also offered clubs that included magazines such as Harper's Monthly, McClures, the Woman's Home Companion, and the Youth's Companion. Twenty years later, the Homestead's clubs included twenty different other newspapers and magazines. In 1918, the Homestead offered arrangements with twice as many publications. Both of the other papers also maintained large "clubbing lists." 37

A third way that farm newspapers courted subscribers was by offering premiums. Some papers offered gifts for clubs of particular sizes. In December of 1896, the Prairie Farmer offered two entire pages of premiums for subscribers. One was aimed at women and one at men. The women's page offered useful items for women's household work and decorative items for the home, such as the "Superior Steam Cooker," for eight new subscribers, and "Our New Alphabet and Doily Stamping Outfit," for one new subscriber. The Prairie Farmer offered similarly useful items for farm work, such as "The Russell Staple Puller and Wire Splicer," for four new subscribers and the "'Cyclone' Corn Sheller," for ten new subscribers. ${ }^{38}$ Other premiums were offered just for subscribing or renewing a subscription. The Ruralist offered pocket knives, seed packets, and silver teaspoons, all for a year's subscription. Finally, books were often used as premiums: the Prairie Farmer offered the "lavishly illustrated" Early Life of Lincoln, the Missouri Ruralist offered Webster's Dictionary, and Wallaces' Farmer offered Henry Wallace's Letters to the Farm Boy. ${ }^{39}$ 
Farm newspapers also sponsored contests. Some of these were in conjunction with group club-raising, as papers offered prizes for the largest clubs. In December 1896 the Prairie Farmer offered a fifty dollar gold watch to the "old subscriber sending us the largest number of new subscribers between now and May 1st, 1897." Wallaces' Farmer awarded a hand-made harness worth thirty-five dollars for the largest number of subscriptions sent in between November 15, 1896 and January 15, 1897.40 Ten years later the paper offered cash to its club raisers:

During the present subscription season which closes April 17, 1907, Wallaces' Farmer will distribute $\$ 3,000$ in cold cash among its club raisers. . . $\$ 2,000$ will be given in fixed prizes, while $\$ 1,000$ will be distributed pro rata among all who send more than twenty names and do not win any of the large general prizes. ${ }^{41}$

In 1912, the Missouri Ruralist offered a piano to the club-raiser with the largest number of new subscriptions. Such large payments and valuable prizes must have provided significant incentives to club-raisers. ${ }^{42}$

Other contests were more like lotteries. Between 1903 and 1905, the Ruralist participated in several contests sponsored by the Press Publishing Association of Detroit, Michigan. These contests provided huge prizes-first prize was $\$ 10,000$ cash in one contest, $\$ 5,000$ in another-if one subscribed to the Ruralist and sent in the closest guess to a large, agreed upon number. One contest used the number of admissions to the St. Louis World's Fair in May, 1904, another the total popular vote for president in November of that year. One can view these contests as early versions of the Reader's Digest or Publisher's Clearing House sweepstakes that began in the 1960 s. ${ }^{43}$ Contests such as these generated enthusiasm for subscribing and for promoting the paper among one's neighbors.

A final way that these farm newspapers worked to increase circulation was by employing subscription agents. Some newspapers used traveling agents assigned to specific areas by the journal. These agents usually worked for commissions only, although some papers offered a salary in addition to commissions. Billy Brantley suggests that the Missouri Ruralist's increase in circulation between 1910 and 1915 was due to the subscription agents employed by the Capper Farm Press companies after Arthur Capper bought the newspaper. ${ }^{44}$ However, many traveling subscription agents "suffered from the attitude of farmers that he was just another 'swindler' making the rounds to secure money from unsuspecting rural families." 45 Several times in the 1910 s, farm newspapers reported on actual impostors who absconded with money for subscriptions. The 
papers gave their descriptions and warned readers to contact the proper authorities if they encountered them. ${ }^{46}$

Local agents-often the local postmaster-had less trouble with such charges. In 1899 the Prairie Farmer claimed that such agents could make from two to three dollars a day. ${ }^{47}$ Each winter the paper also advertised for good agents: "We want hustlers who can put in most of their time for us. To such applicants we will give exclusive territory, and make a liberal offer. State how many days each week you will work for us; and what township you want to commence work in." 48 Similar requests were made in Wallaces' Farmer and the Iowa Homestead in the $1890 \mathrm{~s} .{ }^{49}$ By the 1910s, Wallaces' Farmer did not employ agents as such, but the premiums and cash payments the paper gave to club-raisers amounted to much the same thing.

Papers employed different combinations of these methods in keeping with their attitudes and business plans. Wallaces' Farmer, for example, put group club-raising at the center of its plan for circulation increase. The paper offered premiums to club raisers, enrolled them in contests automatically, sent them sample copies to distribute, and gave them reduced subscription rates. By contrast both the Prairie Farmer and the Missouri Ruralist made offers to individual subscribers: special low prices, free premiums, contests, and dual-subscription clubs. The Iowa Homestead also emphasized offers to individuals, but the paper mainly stressed dual subscription clubs and premiums. Thomas C. Leonard has suggested that such personal offers made circulation of all kinds of newspapers explode in the nineteenth century. ${ }^{50}$ The fact that Wallaces' Farmer made few of these overtures to individual readers may partially explain why it had the lowest circulation of the four papers in 1920.

Farm newspapers' policies concerning subscriptions also influenced circulation. It has been noted that Wallaces' Farmer strictly adhered to a policy of stopping shipment of a paper when a reader's subscription expired. By contrast, the Prairie Farmer, between 1905 and 1907, included the following policy in its masthead:

How to discontinue. We have no desire to continue this paper to any one who does not appreciate its value. We rely on the subscriber to notify us whenever he wants it to stop. It will be continued until ordered stopped by the subscriber himself, and all back subscription must be paid to date of discontinuance. ${ }^{51}$

It seems that the Missouri Ruralist and the Iowa Homestead had similar policies until a 1907 ruling by the United States Postmaster General 
forced them to stop sending papers to those in arrears more than one year. ${ }^{52}$ Between 1918 and 1920, however, the Homestead maintained in its masthead that "It is our custom to continue sending this journal to each of our subscribers as find it inconvenient to renew at expiration. If you do not wish the subscription continued after expiration, please notify us." 53 In light of the postal regulation, they could only have continued sending the paper for one year. Still, such subscription policies sustained large circulation lists; Wallaces' Farmer's policy may also help to explain why it lagged behind the other papers in circulation. Those papers' practices certainly angered Henry Wallace.

These efforts to get new subscribers demonstrate that farm newspapers attempted to get as many subscribers as possible within their areas of coverage. They reached out to all farmers, all country people. This was certainly good business practice; when circulation numbers increased, a publication could charge higher prices for advertising. Editors seemed genuinely concerned that they reach all as many farmers as possible with their message, however. They consistently claimed that all farmers should read their paper. Henry Wallace claimed that "Every farmer needs ... an agricultural paper that he believes to be entirely devoted to his interests." $54 \mathrm{He}$ believed that Wallaces' Farmer had subscribers from among all socio-economic levels of Midwestern farming:

Wallaces' Farmer reaches, for example, tenants with very limited means,
farmers who are heavily in debt for their land and whose working capi-
tal is small, farmers with ample means to do about what they want to
do, [and] landlords who are living from the income of their farms... 555

Similarly, the editor of the Missouri Ruralist proclaimed that "the avowed purpose of the Missouri Ruralist is to become the home farm newspaper of every farm home in the state." ${ }^{56}$ The other two papers published similar editorials. All four papers reached out to tenants and farm owners of all income levels. They proclaimed that all the different types of Midwestern farmers read their papers. The extent to which they actually reached a broad audience will be evaluated in chapter four. ${ }^{57}$

These farm newspapers hoped to reach farmers in a wide-ranging geographic area during the 1890 s. All four papers attempted to reach a broader audience than just their state of publication. Thus, the Prairie Farmer targeted "western farmers," the "farmers and stockmen in the Mississippi and Missouri valley states." 58 Editorials in Wallaces' Farmer argued for its usefulness in other parts of the Midwest. In addition, from 
1898 to 1909 its subtitle was originally "A Weekly Journal for Western Farmers." 59 The Ruralist was similarly aimed at "Western farmers," not just in Missouri but "Missouri and her contiguous neighboring states." 60 Finally, the Iowa Homestead saw itself as serving the middle West and asserted that its readers were "residents of Iowa, Illinois, Nebraska, and adjoining states." 61

This expansive view of their geographical coverage had narrowed by 1920 for three of the four newspapers. The most obvious change came to the Ruralist when Arthur Capper bought it in 1910 and renamed it the Missouri Ruralist. Hereafter the paper primarily served that state. Indeed, by 1925 Capper owned half a dozen farm newspapers, one national paper and five dedicated to its particular states: Kansas, Missouri, Michigan, Ohio, and Pennsylvania. The Iowa Homestead and Prairie Farmer's reach also contracted, though less obviously. In 1907, James Pierce bragged that almost sixty thousand of the Homestead's subscribers were in Iowa, and thirty thousand were in Illinois and Nebraska. Ten years later, however, his boast was the paper's coverage of 110,000 of the 217,000 farm homes in Iowa. During the 1910s, the Prairie Farmer also emphasized its circulation in Illinois rather than elsewhere. The one exception was Wallaces' Farmer, which continued to make claims for its applicability and reception across the Midwest throughout the 1910s. ${ }^{62}$

Table 2 compares the circulation of the four farm newspapers examined to the total population and number of farms in Iowa, Illinois, and Missouri. At the turn of the twentieth century, none of the papers was reaching a significant number of farm homes in the state in which it was published. Twenty years later, however, the total circulation of the Prairie Farmer and the Iowa Homestead were over one half of the number of farms in Illinois and Iowa, respectively. The circulation of the Missouri Ruralist was over a third of the number of farms in Missouri, and Wallaces' Farmer's circulation exceeded one quarter of the number of farms in Iowa. These figures suggest that a significant proportion of farmers in these three states received one of the farm newspapers studied.

Whatever the geographical limits, however, all four farm papers consistently worked to get their paper into every farmer's home. They used proven methods, including low prices, clubs, premiums, contests, and agents to build their circulation lists during the last years of the nineteenth century and the first two decades of the twentieth. Each worked to deliver its message to all rural Midwesterners. By 1920, it appears that they were succeeding in their efforts to reach the farms in these three states. 
Table 2. Circulation Figures for Midwestern Farm Newspapers Compared to Census Figures for Number of Farms and Total Population

\begin{tabular}{|c|c|c|c|c|}
\hline Year & $\begin{array}{l}\text { Total } \\
\text { Population } \\
\text { of Iowa }\end{array}$ & $\begin{array}{l}\text { Number of } \\
\text { Farms } \\
\text { in Iowa }\end{array}$ & $\begin{array}{l}\text { Circulation of } \\
\text { Iowa Homestead }\end{array}$ & $\begin{array}{l}\text { Circulation of } \\
\text { Wallaces' Farmer }\end{array}$ \\
\hline 1900 & $2,231,853$ & 228,622 & 40,076 & 23,769 \\
\hline 1910 & $2,224,771$ & 217,044 & 100,000 & 54,006 \\
\hline 1920 & $2,404,021$ & 213,439 & 138,194 & 65,200 \\
\hline Year & $\begin{array}{l}\text { Total Population } \\
\text { of Illinois }\end{array}$ & $\begin{array}{l}\mathrm{Nu} \\
\text { in I }\end{array}$ & $\begin{array}{l}\text { aber of Farms } \\
\text { linois }\end{array}$ & $\begin{array}{l}\text { Circulation of } \\
\text { Prairie Farmer }\end{array}$ \\
\hline 1900 & $4,821,550$ & 264 & 151 & 25,000 \\
\hline 1910 & $5,638,591$ & 251 & 872 & 42,052 \\
\hline 1920 & $6,485,280$ & 237 & 181 & 112,128 \\
\hline Year & $\begin{array}{l}\text { Total Population } \\
\text { of Missouri }\end{array}$ & $\begin{array}{l}\mathrm{Nu} \\
\text { in } \mathrm{I}\end{array}$ & $\begin{array}{l}\text { aber of Farms } \\
\text { lissouri }\end{array}$ & $\begin{array}{l}\text { Circulation of } \\
\text { Missouri Ruralist }\end{array}$ \\
\hline 1900 & $3,106,665$ & 284 & 886 & n. p. \\
\hline 1910 & $3,293,335$ & 277 & 244 & 10,500 \\
\hline 1920 & $3,404,055$ & 263 & 004 & 90,042 \\
\hline
\end{tabular}

Key: $\quad$ n. p. $\quad-\quad$ Not published

Sources: Circulation figures: Table 1; Census figures: United States Historical Census Data Browser, http://fisher.lib.virginia.edu/census/; internet; accessed 30 September 2004.

\section{CONTENT}

The four farm newspapers provided similar types of content for their readers. They all were tabloid-sized and had four columns to a page. In the 1890s, all ran articles and editorials on the front page of the paper. By 1912, however, all four were printing a full-page photograph or other illustration on the cover. The paper's content began on the second page. Inside, all regularly included editorials, articles, departments, and letters to the editor.

\section{Editorials}

All of the papers printed editorials on issues confronting Midwestern farmers. These were usually set apart on one or two pages by themselves, often accompanied by the masthead and free from advertising. They often were 
printed with three larger columns to the page. Editorials addressed issues concerning farm newspaper publishing, agriculture, and rural social life. While farm newspapers occasionally covered politics, their treatment was usually non-partisan. They normally published editorials about issues and agitated for laws they thought were important to farmers, such as tariff changes, railroad regulation, and national parcel post delivery. Editorials rarely endorsed specific parties or candidates. Most likely this was so that they could appeal to as broad a readership as possible. ${ }^{63}$

In his editorials describing Wallaces' Farmer's philosophy, Henry Wallace gave several useful taxonomies for distinguishing among farm newspapers at the turn of the century. While his descriptions were often polemical, they do furnish helpful ways of categorizing farm newspapers. As we have seen, distinctions could be based on the paper's subscription policy, degree of specialization, or geographical coverage. Another categorization concerned editorials. Wallace was proud that his paper had a strong editorial voice. His paper, he argued, took predictable positions on the issues that confronted country people and he stood behind his editorial pronouncements. He attacked papers that did not even give the editor's name in their masthead. Such papers' editorial pages, Wallace asserted, were little more than mouthpieces for their business managers. They existed merely to make money by selling advertising. He warned that such papers often sold their editorial positions to the highest bidder. ${ }^{64}$

Of the four papers, Wallaces' Farmer and the Missouri Ruralist had the most consistent editorial voice over the entire period of their existence. The Iowa Homestead and Prairie Farmer published for years without giving the names of their editors in their mastheads. These papers' editorials did not become a prominent part of their content until the early 1900s. In 1905, the Homestead acknowledged James Atkinson as its editor-in-chief and Chauncey P. Reynolds became editor of the Prairie Farmer. In fact, beginning in 1913, The Iowa Homestead had two sets of editorial pages. One was the regular editorial page written by editor James Atkinson. The other was titled "The Publisher's Views on Topics of the Times" and expressed the opinions of James M. Pierce. While the editorial page consistently occupied only two pages, "Publisher's Views" grew over the years until it covered four or five pages and became the central feature of the paper. ${ }^{65}$

Finally, by the 1910s, all of the newspapers were addressing social or country life issues in their editorials. They recommended specific changes to rural Midwesterners both in how they farmed and in how they lived. Wallaces' Farmer was concerned with such issues in the 1890s; the other three papers became more interested in the 1900s. The motto or slogan of Wallaces' Farmer was “Good Farming_Clear Thinking-Right Living.” In 
an article of the same name published in 1910, editor Henry Wallace explained that his paper's purpose was not only to promote the best of farming methods but also to instruct farmers in their civic and moral duties. "We could not be content to publish a paper that would enable the farmer to make more money by improved methods of farming without at the same time reminding him of his ever-widening and increasing duties as a citizen." 66 The Iowa Homestead made the same claims in a promotional pamphlet published around 1911. Titled "A Vital Interest Problem for the Farmer" and subtitled "How to make the farm pay better-How to live better-How to more fully accomplish the aims of life," it asserts that:

An agricultural paper should do more than to $[s i c]$ make it easier to earn a good living. ... It should aid in making the country school better. ... In short, the agricultural paper should bring its weekly message to every member of the family - that every task should be lightened and the joy of labor increased. ${ }^{67}$

Midwestern farm newspapers shared the conviction that the farm newspaper was important not just for farming information but also for social commentary and advice.

The editorial stances of all of these papers suggest that Van Derhoof's assertions concerning editors' roles should be revised. While their editors did not control these early twentieth century papers as they had in the mid-nineteenth century, the papers were not passive information conduits. Editors argued for specific changes in country people's lives, not just in their farming methods. At the same time, however, the social advice editors delivered was influenced by the reform movements of the early twentieth century, so they can be seen as channels for these ideas. These recommendations were often echoed in the articles that farm newspapers printed.

\section{Articles and Departments}

The articles in these papers addressed agricultural, business, and social issues. Articles on farming instructed readers of agricultural methods or told of farmers that had found such methods successful. They gave suggestions on how to grow various crops, choose seed, care for livestock, and avoid weeds, insects, and other pests. Articles also gave directions for marketing crops and stock, reported on price trends, and gave crop and price outlooks for states and regions served by the paper. Like editorials, articles also discussed new and better ways of living in rural areas. These articles were written either by the editor of the paper, by staff, or by special contributors.

In general, the four papers gave agricultural recommendations that were in the mainstream of "progressive farming" for the turn of the century. Authors 
suggested that crop farmers do all they can to maximize their yield per acre by using fertilizer, crop rotation, and choosing the best seeds. By the end of the period the papers were covering the use of tractors and other labor-saving machinery. Livestock farmers were exhorted to make use of silos, a variety of different feed mixes, and to improve their livestock breeds. Many articles exhorted farmers to put their operations on a more scientific footing. These articles resonated with many Midwestern farmers, who did want to expand their operations and be more successful. Success would make it possible for them and their families to remain in the country, and it would enable them to partake of life-improving technological and material improvements. ${ }^{68}$

During the period, all four of the papers also began including more feature articles. Features were longer, had larger headlines, and usually appeared in the first five or six pages of the paper. Like regular articles, features might be authored by the editor, by newspaper staff, or by special contributors. Such feature articles offered more in-depth coverage of good farming methods and good ways of rural living. One specific type of feature article may be called the "How We Did it Right" article. Such articles focused on one farmer or one farm family and described how they were farming or living successfully. Sometimes a "How We Did it Right" article focused on a particular school district or church congregation and described how it met its community's needs. These articles were both descriptive and persuasive.

As a result, it is difficult to distinguish strictly between editorials and articles in farm newspapers. Articles did not simply report the results of new initiatives in farming or rural life; they often actively advocated them. Authors celebrated the success of the subjects of the article and argued that all their readers should follow their example. Such articles and features were usually extensions of the editorial stance of the paper itself. For instance, chapter five will detail how editorials advocating new roles for the rural church were coupled with articles and feature stories about churches that had taken on such new roles. Both editorials and articles gave advice to their readers on how to farm and how to live.

After several pages of features, articles, and editorials, all four papers divided the rest of the issue into departments. All four of the papers had individual departments dedicated to field crops, beef cattle, hogs, sheep, poultry, dairying, and horticulture. In addition, all of the papers had some kind of home department to address issues of interest to rural women. Other departments appeared in different papers at different times, including veterinary and legal departments. A department had its own department title and provided articles and letters from readers about their topic. It often also had its own editor to answer readers' questions. Between 1913 and 1919, the Missouri Ruralist did 
away with department titles, but the paper continued to print the same mixture of articles on these topics on roughly the same pages each issue.

Departments aimed at women and children of these farm papers occupied from one to four pages each issue. Articles in Home departments addressed housekeeping, child rearing, cooking, sewing, gardening, and making life pleasant on the farm. The department also provided women with a forum for expressing their opinions on a range of issues. In addition to the subjects listed above, departments printed letters concerning the farming, women's rights, woman suffrage, and social issues such as the rural school and the rural church. Home departments will be discussed in detail in chapter seven. Children's departments printed short stories, moral injunctions, and other material aimed at rural children. They also printed numerous letters from children about their lives, schools, pets, reading, and plans for the future.

A final feature provided by all four farm newspapers in the 1910s was serialized fiction. The Prairie Farmer was first, serializing The Other Side of the Door, a romance by Lucia Chamberlain in 1910.69 Wallaces' Farmer printed its first serial two years later: Uncle Tom Andy Bill by Charles Major. An adventure story about the frontier West, Henry Wallace described it as "a good sort of story to read as it was told-to the family gathered around the fireside." 70 The Homestead scored a victory in 1918 when it secured exclusive rights to serialize Hamlin Garland's A Son of the Middle Border. In 1915 and 1916, the Missouri Ruralist printed Alton of Somasco about a ranch in British Columbia. ${ }^{71}$

With articles and features on such a variety of material-agricultural, homemaking, and general reading-farm newspapers hoped to serve the reading needs of all members of the rural family. Providing a product that appealed to as many as possible was an important part of farm newspapers' strategy to reach out to all farmers. A variety of material both attracted and retained subscribers. ${ }^{72}$

\section{Letters}

Finally, all four papers printed letters from readers. While all published correspondence regularly in individual departments, several of the papers also provided special departments devoted to letters. For instance, from 1896 to 1904, the Iowa Homestead printed a supplement called the “Special Farmers' Institute Edition." The paper's management chose the topics to be addressed and announced them about a month in advance. Then letters were collected and printed in a supplement to the regular newspaper, usually without advertising. The feature was occasional in 1896; the next year it became monthly. In 1898 the paper added a section 
titled "Aftermath;" it consisted of letters that discussed previous "Farmers' Institute" letters. In 1899, the pages of the Farmers' Institute Editions were numbered consecutively, apart from the regular paper, and they added 280 pages to the year's output. The January 1899 edition was thirty-two pages long and contained the following topics:

"Farm Prospcrity; Should Its Evidences First Appcar in the Barn, Stock and Machinery or in the Home?"-70 correspondents; "Winter Work: Of What Should it Consist and How Be Planned?"-36 correspondents; "Sheep Husbandry; Advantages and Disadvantages and Best Methods of Management" -37 correspondents; "Aftermath" -51 correspondents. ${ }^{73}$

This large-scale effort at publishing readers' opinions was discontinued in $1904 .{ }^{74}$

In 1913, the Homestead inaugurated another effort to print the opinions of its readers titled "The Experience Meeting." This weekly department printed letters to the editor on topics addressed by the paper. As time went on, it increasingly became a forum for discussing previous letters to "The Experience Meeting." Discussants often referred to previous authors by name in responding to their assertions about silos, breeding, and even social issues such as school consolidation. They sometimes addressed the comments of several previous discussants in one letter. This forum for readers was discontinued three years later. ${ }^{75}$

In the 1910s, the Missouri Ruralist and Prairie Farmer had similar departments for letters to the editor. Between 1914 and 1916 the Prairie Farmer printed letters in a department titled "Little Editorials by Our Readers." The department title changed to "Ideas and Experiences from Prairie Farmer Readers" in 1916 and to "Our Readers' Editorial Page" in 1918. The Missouri Ruralist inaugurated a department in 1913 titled "Things the People Say." The department title was changed to "Around the Ruralist Family Table" early the next year. ${ }^{76}$ The only paper that did not have a special section for letters was Wallaces' Farmer, but it distributed a large number of letters throughout the paper every week.

These letters to the editor did not always agree with the stance of the editors of the papers. They often took issue with articles or editorials in previous issues of the paper. Therefore, they can be useful in assessing the contours of reader response. The ideas of readers are difficult to trace, especially before the advent of polling and survey data in the 1930s. Three common methods cultural historians use to investigate readers' opinions of subjects addressed by mass media outlets are 1) examining the content of the publication, 2) looking at letters to the editor, and 3) consulting social history studies of target 
populations. All three are used in chapters five through seven. ${ }^{77}$ Letters to the editor must be used with care. Since the editor of a newspaper decided what was printed, often letters that did appear were in sympathy with the editors' vision and supported the stances taken in editorials and articles. However, used carefully, letters can provide some glimpses of readers' responses. ${ }^{78}$

By 1920 , all four of the Midwestern farm newspapers examined had a strong, personal, editorial voice. All of them printed editorials, articles, and features that instructed readers about both agricultural methods and rural ways of living. By printing letters to the editor, however, they also provided a forum for the discussion by rural Midwesterners of these recommendations. The many pages of editorial content printed every week were mainly paid for by advertising.

\section{ADVERTISING}

By the 1890s, farm papers had already shifted from a reliance on subscriptions to a reliance on advertising for the major portion of their revenues. Even the highest subscription price charged by any of the four farm newspapers during the period-one dollar a year-would barely have been enough to cover printing a sixteen-page paper and mailing it to the subscriber every week. Overhead costs, employee salaries, and investment returns were all provided by advertising revenues. ${ }^{79}$

While the number of pages printed by all the farm papers examined grew between 1895 and 1920, the percentage of those pages devoted to advertising also grew. The amount of advertising appearing in the four farm newspapers is given in Table 3. Wallaces' Farmer shows the most striking growth. In 1896, when the issue sampled had sixteen pages, just over a quarter of the paper was advertising. By 1920, the paper had more than quadrupled in size to seventy-two pages, but advertising had increased to occupy almost three-quarters of the paper, or fifty-one pages. The other papers exhibited similar rates of growth. In 1920, at least half of the pages of all four papers were taken up by advertising. In addition to the expansion of advertising, the character of advertising also changed. In the 1890s, nearly all of the advertisements in farm newspapers were related to agriculture; they were placed by farm implement manufacturers, livestock breeders, and seed and feed companies. During the early twentieth century, more and more advertising was for consumer products, such as sewing machines, educational institutions, and automobiles. By 1920, advertisements for Rumford baking powder, Coca-Cola, Maytag washing machines, and Studebaker automobiles were as common as those for Avery tractors, Galloway manure spreaders, Frank Iam's stallions, and Northrup-King seeds. 
Between 1895 and 1920, advertising in farm newspapers both expanded and changed, just as the editorial content and the circulation of these papers had done. During these years of rural prosperity, both improved agricultural items and consumer goods came to occupy a larger portion of the typical issue of a Midwestern general farm newspaper.

Table 3. Advertising in Selected Midwestern Farm Newspapers

\begin{tabular}{lllll}
\hline Date & Total & Total & Columns of & $\%$ of Issue \\
Sampled & Pages & Columns & Advertising & \begin{tabular}{l} 
Advertising \\
\hline
\end{tabular} \\
\hline
\end{tabular}

Iowa Homestead

\begin{tabular}{lllll} 
3 January 1896* & 24 & 96 & 27.5 & $29 \%$ \\
4 January 1900 & 28 & 112 & 45 & $40 \%$ \\
5 January 1905 & 40 & 160 & 78.5 & $49 \%$ \\
6 January 1910 & 64 & 256 & 151.5 & $59 \%$ \\
7 January 1915 & 56 & 224 & 104.5 & $47 \%$ \\
1 January 1920 & 96 & 384 & 228 & $59 \%$ \\
\hline
\end{tabular}

\section{Prairie Farmer}

$\begin{array}{lllll}\text { 11 January 1896* } & 16 & 64 & 7 & 11 \% \\ \text { 6 January 1900 } & 16 & 64 & 14.5 & 23 \% \\ \text { 5 January 1905 } & 16 & 64 & 20 & 31 \% \\ \text { 1 January 1910 } & 24 & 96 & 44.5 & 46 \% \\ \text { 2 January 1915 } & 32 & 128 & 54 & 42 \% \\ \text { 3 January 1920 } & 56 & 224 & 124 & 55 \%\end{array}$

\begin{tabular}{llcll}
\hline & \multicolumn{5}{c}{ Wallaces' Farmer } \\
3 January 1896* & 16 & 64 & 16.5 & $26 \%$ \\
5 January 1900 & 20 & 80 & 35 & $44 \%$ \\
6 January 1905 & 32 & 128 & 63.5 & $50 \%$ \\
7 January 1910 & 40 & 160 & 87 & $54 \%$ \\
1 January 1915 & 32 & 128 & 52 & $41 \%$ \\
2 January 1920 & 72 & 288 & 204 & $70 \%$ \\
\hline & \multicolumn{5}{c}{ Missouri Ruralist } \\
5 January 1905 & 16 & 64 & 17 & \\
6 January 1910 & 16 & 64 & 20.5 & $32 \%$ \\
5 January 1915 & 20 & 80 & 39 & $49 \%$ \\
5 January 1920 & 56 & 224 & 112.5 & $50 \%$ \\
\hline
\end{tabular}

*1896 was chosen so that Wallaces' Farmer could be compared with the other two papers.

Source: Number of columns of advertising counted in the first issue of each year of each paper. 


\section{$* * *$}

Midwestern farm newspapers reached out to as many country people as possible. Owners and editors hoped to find subscribers in all types of farm homes of all different socio-economic levels. They worked to build circulation by offering low subscription prices, club arrangements, premiums, and prizes to rural Midwesterners. They also furnished reading matter to all members of the farm family and provided a forum for country people to discuss issues of interest. The distribution of this content was made possible by revenue from advertisements, which took up more of the paper and promoted more consumer goods as the period progressed. The editors and publishers of Midwestern farm newspapers guided their organizations through these changes. Their backgrounds and identities are the subject of chapter two. 


\title{
Editors and Publishers:

\author{
The Faces Behind the Midwestern Press
}

\begin{abstract}
Who edit the agricultural papers? Men, as a general thing, who fail in the poetry line, yellow covered novel line, sensation-drama line, city-editor line, and finally fall back on agriculture as a temporary reprieve from the poor-house. You try to tell me anything about the newspaper business! Sir, I have been through it from Alpha to Omaha, and I tell you that the less a man knows the bigger noise he makes and the higher the salary he commands.

- Mark Twain, "How I Edited an Agricultural Paper Once"1
\end{abstract}

From May 1870 to April 1871, Samuel Clemens wrote a humor column for The Galaxy magazine called "Memoranda. By Mark Twain."2 In July of 1870, the column began with an essay titled "How I Edited an Agricultural Paper Once." In it, the author relates how he once took a job as a substitute editor of a farm newspaper because the pay was good. According to this account, the only issue printed under his editorship exhorted his readers to shake their turnip trees to get the turnips to fall, to set out their corn stalks and buckwheat cakes in July, and to avoid planting pumpkins in the front yard because they are inferior shade trees. When the paper came out, the local farmers were scandalized; one feared he was going insane after reading the editor's columns. As a result, the regular editor of the paper returned from his vacation early to take back control of the paper. He castigated his replacement for knowing nothing about the subject he wrote about: agriculture.

Twain's fictional response to the editor was a shrewd critique of journalism in general and agricultural journalism specifically. He asserted that most journalists write about things that they do not really know: those who critique dramas can not act, those who review books do not write books, and those who write for temperance papers are not sober. It should come as 
no surprise, then, for one who knows nothing about agriculture to write for an agricultural paper. Farm newspaper editors, Twain contended, were failures at regular newspaper journalism who had shifted to the farm press. But he also argued that he had done what he promised to do: he had increased and broadened the paper's circulation. While farmers may have found it useless, others found it riveting. If he had been allowed several more weeks, he could have increased its circulation to over twenty thousand. For this reason, he told the editor that "you are the loser by this rupture, not me. ..."3

Twain's article poses several good questions for the historian of the farm press: Who were the editors and publishers of farm newspapers? Were they farmers? Did they know about agriculture from experience? What was their relationship to their readers? While this chapter will not assess the truth of Twain's pronouncements when he wrote them in 1870, it will consider their applicability at the turn of the twentieth century. The previous chapter examined the character of Midwestern farm newspapers themselves between 1895 and 1920. This chapter will consider the identity of the editors and publishers of those newspapers during the period.

All four of the farm newspapers examined were published in significant cities of the Midwest: Des Moines, Chicago, Kansas City, and Topeka. Therefore, the papers' staffs lived and worked under vastly different circumstances than the rural Midwesterners for whom they wrote. The publisher and editor of a farm newspaper had an enormous influence on the character and success or failure of the paper. ${ }^{4}$ Their biographies enable us to better understand their identities.

\section{“THE UNCERTAIN FIELD OF AGRICULTURAL JOURNALISM": PUBLISHERS}

The farm papers studied were published by newspapermen from a variety of backgrounds. James M. Pierce, publisher of the Iowa Homestead, was born in 1848 on a farm near Upper Sandusky, Wyandotte County, Ohio. His ancestors had been farmers in New Jersey, Western Pennsylvania, and Ohio. He went into the newspaper business early in life, becoming at age fifteen an apprentice in a county-seat newspaper office in Ohio. In 1867 he moved west to Missouri, apparently to farm. Three years later, however, he returned to the newspaper business by buying the Grant City Star in Worth County. To do so he borrowed nine hundred dollars at an interest rate of three percent a month. The paper was a success, and five years later he started a second paper, the Hopkins Journal in Nodaway County. By the mid-1880s, he had moved into southern Iowa and bought the Taylor County Republican and the Osceola Sentinel in Clarke county. All of these were county-seat papers. ${ }^{5}$ 
Pierce later observed that "I must have been pretty optimistic and venturesome in those days, else I would never have quit the proven profitable field of county-seat newspapering for the uncertain field of agricultural journalism." $\mathrm{He}$ entered this new field in 1885 by purchasing the Iowa Homestead from J. H. Duffus for twenty thousand dollars. Henry Wallace had been editing the paper for two years. Wallace later claimed that he told Pierce that he had paid eight to ten thousand dollars too much for the Homestead, so Wallace agreed to edit the paper for ten dollars a week if he could buy stock in the company. Pierce kept Wallace on. Under their leadership the paper grew in both size and circulation. ${ }^{7}$

After Henry Wallace left the paper in 1895, Pierce remained concerned about both the editorial and business sides of the operation. He employed at least three editors over the next twenty-five years: his lawyer and business partner S. F. Stewart, James Atkinson, and John Thompson. But it appears that Pierce was the guiding force behind the paper. In 1913 the paper began including a column titled "Publishers Views on Topics of the Times," consisting of two or three opinion pieces. Pierce's picture appeared at the top of the page, and his signature was reproduced after the last piece. Early the next year, the column moved to a prominent position on the paper's first page of editorial matter, a position occupied by feature articles in most other farm newspapers. By 1917 and 1918, "Publisher's Views" often included five or more editorials, sometimes spilling onto four or five pages. Articles about the Homestead suggest that Pierce did not write the column himself. Instead, he had others argue for his positions. Even if Pierce did not write these pieces, however, they embodied his ideas and dominated the paper. ${ }^{8}$

Pierce was one of the first to buy and publish multiple farm journals in multiple regions, buying both the Wisconsin Farmer and the Farmer and Stockman of Kansas City in the early 1900s and publishing them, along with the Homestead, as "Pierce's Farm Weeklies." James M. Pierce died on November 1, 1920, after thirty-five years as publisher of the Homestead. His son Dante M. Pierce immediately took his place, pledging to continue his father's policies. Dante continued the "Publishers Views on Topics of the Times" feature, and his picture was placed along with his father's at the top of the column. ${ }^{9}$

Several characteristics of James Pierce's ownership of the Iowa Homestead stand out. When he bought the paper, it already had a significant previous publishing history. In addition, while Pierce was born and raised on a farm, he became interested in journalism while in his teens. He left farming at the age of twenty-two for a life in county seats and in Des 
Moines. Pierce came to agricultural journalism after owning small-town newspapers in southern lowa and northern Missouri. He exercised a significant amount of control over the content of the paper, firing an editor over editorial differences and creating a column to express his opinions. Finally, he created a multi-publication chain by buying farm newspapers in Missouri and Wisconsin. Publishers of other Midwestern farm newspapers shared some of these traits.

Burridge D. Butler, publisher of the Prairie Farmer from 1908 to 1948, was born on February 5, 1868, in Louisville, Kentucky. His father was born in England and became an itinerant preacher for the Disciples of Christ. His mother was a soft-spoken Christian poet from Louisville, Kentucky. Burridge's childhood was spent moving with his father from pastorate to pastorate; the family lived in Michigan, Canada, Ohio, and Pennsylvania. Burridge left home shortly after his mother died in 1884 . During the next ten years he worked as a journalist, editor, business manager, and publisher for several newspapers, including the Louisville Evening Times, the Cincinnati Enquirer, and the Grand Rapids Morning Democrat. In 1895 he took a job as an advertising salesman with the Scripps-McRae chain of newspapers. He was made assistant manager of Scripps's Chicago sales office the next year. ${ }^{10}$

In 1899, he joined with two other employees of the Scripps-McRae organization to found the Good Luck League of newspapers. With the encouragement of Edward W. Scripps, they started a daily newspaper in Omaha. The partners continued by starting similar daily papers in Duluth, Des Moines, Minneapolis, and St. Paul, and by purchasing papers in St. Joseph and Sioux City. Interest in what they had come to see as an untapped rural market led them to buy the Rural World of Kansas City in 1906, the Farm Magazine of Omaha in 1907, and the Prairie Farmer in 1908. Tired of the long hours and travel necessary to manage so many papers, Butler left the Good Luck League in 1909. He took over sole ownership of the Prairie Farmer as a major part of his settlement. He published the paper from Chicago for the next forty years. ${ }^{11}$

Butler, along with editor Clifford V. Gregory, returned the Prairie Farmer to its former prominence among American farm newspapers. In 1909 the paper had the lowest circulation of five general farm newspapers published in Illinois. By 1931 the paper had absorbed its last rival. Circulation increased from around thirty thousand in 1908 to over one hundred thousand in 1920. Butler was also a prominent participant in the creation of the Audit Bureau of Circulations in 1914. ${ }^{12}$

While Burridge D. Butler shared a number of characteristics with James M. Pierce, there also are striking differences. Like Pierce, Butler 
purchased a farm newspaper with a long publishing history. Like Pierce, he came to agricultural journalism from newspaper journalism. But while Pierce owned and operated county seat papers, Butler owned and managed newspapers in major Midwestern cities. Butler's association with the Good Luck League chain of farm newspapers was similar to Pierce's Farm Weeklies. Unlike Pierce, however, Butler was neither raised on a farm nor had he worked on one before publishing a major Midwestern farm newspaper. Also unlike Pierce, Butler left a multi-publication operation to concentrate on one paper. After taking over the Prairie Farmer in 1908, he only bought farm newspapers that competed with his own and consolidated their operations into those of the Prairie Farmer.

Unlike the Homestead and the Prairie Farmer, which had distinguished nineteenth century publishing histories, the Missouri Ruralist was established in the early twentieth century. Matthew V. Carroll founded The Ruralist in 1902; the first issue appeared on October 16. Carroll was born on a farm near Defiance, Ohio in 1859. In 1881 he moved his family to a farm near Butler in Bates County, Missouri. He farmed there for nine years, intermittently teaching in local one-room schools and writing for the Butler Weekly Union. From 1890 to 1893 he edited the paper. He worked for Lon V. Stephens's gubernatorial campaign in 1896; after Stephens was elected, he appointed Carroll Deputy State Labor Commissioner. Carroll served in the state bureaucracy for four years. In 1900 Carroll moved to Sedalia, Missouri and worked briefly for the Sedalia Sentinel. Two years later he lined up several investors and began publishing The Ruralist. Carroll both owned and edited the paper from 1902 to $1910 .^{13}$

In June 1910, Arthur Capper bought The Ruralist. Capper was born in Garnett, Kansas in July of 1865 . His father was from Staffordshire, England and his mother was from Westmoreland County, Pennsylvania. During high school he worked as the office devil for the local Garnett Journal. After finishing high school in 1884, he left home for a job as a printer with the Topeka Daily Capital. By the time he left the Capital in 1891, he had become the city editor. He wrote for the New York Tribune in 1891 and covered Congress in Washington, D. C. for the Capital in 1892 before returning to Topeka later that year and marrying Florence Crawford. His apprenticeship in newspaper writing was over. ${ }^{14}$

Between 1893 and 1913, Capper built a publishing empire. He began in 1893 by buying the Topeka Mail. In 1895 he purchased the Kansas Breeze and merged the two papers, forming the Mail and Breeze. He built up their circulation by hiring good subscription agents, dropping the paper's subscription price, and advertising heavily in other publications. By 1900 he 
had enough capital to buy the Missouri Valley Farmer, in 1904 he purchased the Topeka Capital, and in 1910 he bought The Ruralist. By 1913, Capper owned and published farm newspapers that served Kansas, Nebraska, Missouri, and Oklahoma. He also owned a magazine (Household), a weekly newspaper (Capper's Weekly), and a daily newspaper (the Capital). ${ }^{15}$

Shortly after he bought The Ruralist in June 1910, Capper renamed it The Missouri Ruralist. Later that year he bought the Breeder's Special of Kansas City and combined the two papers. The paper's editorial, advertising, and printing offices were moved to those of the Breeder's Special in Kansas City. Three years later the entire operation was moved to Capper's plant in Topeka, Kansas. Between 1910 and 1913, the paper had three editors. Capper first bought out Carroll and replaced him with T. W. Morse, the editor of the Breeder's Special. Morse, however, edited the new Missouri Ruralist for only one year. After him, Capper promoted Harry W. Graham from field reporter to editor for four months before returning him to his previous job. Harry R. Nelson served as editor from June 1912 to September 1913, when he resigned because of a conflict with Capper. At this point, Capper chose John Francis Case to come to Topeka and edit the paper. Case edited the paper from 1913 to $1955 .^{16}$

The lives of the two publishers of the Missouri Ruralist provide several striking contrasts. While Carroll was born and raised on a farm, Capper was the son of a tradesman who grew up in small towns. Carroll successfully got a new farm newspaper off the ground; Capper, like Pierce and Butler, bought an existing paper, built its circulation, and eventually eliminated its competition. While Carroll owned only one farm newspaper, Capper-like Pierceowned a chain that published a number of farm papers. Finally, Carroll and Capper came to farm journalism after working on mainstream newspapers of different types: Carroll worked for papers in small towns, while Capper was a correspondent for city papers in Topeka, New York, and Washington, D. C.

Henry Wallace, editor and publisher of Wallaces' Farmer for its first twenty years, had a different personal history than other publishers. Wallace was born in 1839 in Westmoreland County in southwestern Pennsylvania. His parents were Scotch-Irish immigrants from Northern Ireland. Wallace declined to take over the family farm in order to pursue the ministry. He attended several schools before graduating from seminary and being ordained in the Presbyterian Church in the U. S. A. in $1863 .{ }^{17}$ Over the next fourteen years, he pastored churches in Rock Island, Illinois; Davenport, Iowa; and Morning Sun, Iowa. He also served as a chaplain and medical assistant for the Christian Commission in 1865. He married Nancy Cantwell in 1862. Together they had seven children, two of whom died in early childhood. ${ }^{18}$ 
In 1877, Wallace left the ministry. He had contracted tuberculosis, a disease that had already caused the death of both of his parents and seven of his siblings. His respiratory health had deteriorated; pains in his chest and abdomen made it increasingly difficult to preach or study. Advised by his doctor to spend more time outdoors, he resigned his pastorate and moved his family to Winterset, Madison County, Iowa. While a pastor, Wallace had participated in the post-Civil war speculation in Iowa land. He bought low, sold high, and banked his profits. He avoided losing his fortune in the Panic of 1873 and therefore had enough money to buy several farms in Adair County, lowa. He drove a team of horses back and forth from Winterset to the farms to supervise his hired hands and tenant farmers. Over the next several years his health greatly improved. ${ }^{19}$

In the 1880 s, Wallace began a third career as a journalist. Shortly after arriving in Winterset, he became involved in local Republican politics. He occasionally spoke at public gatherings, especially on agricultural matters. In 1880, the editor of the Winterset Madisonian asked him to write about farming for the paper. After several years, he left the paper to found a rival paper, the Winterset Chronicle. He corresponded with a number of other small town newspaper editors who were interested in agricultural writing, including James Wilson of the Traer Clipper and Seaman Knapp of the Gate City Keokuk. ${ }^{20}$ Word of his ability to write about farm issues spread. In 1883 , J. H. Duffus, the new publisher of the Iowa Homestead, hired him to edit that farm newspaper. Five years later, Henry Wallace moved his family to Des Moines to work full-time on the Homestead. ${ }^{21}$

Wallace edited the Homestead for twelve years, two under Duffus and ten under James M. Pierce. Shortly after Pierce fired Wallace in early 1895, Henry Wallace joined his sons to publish Wallace's Farm and Dairy, Wallaces' Farmer and Dairyman, and eventually Wallaces' Farmer. Henry Wallace continued as general editor of the paper for the next twenty years. The paper competed fiercely with the Homestead for readers in lowa and surrounding states, but it never matched the Homestead's circulation numbers. ${ }^{22}$

By the end of his life, Henry Wallace had become a prominent spokesman for rural interests. In 1908, President Roosevelt appointed him to the Commission on Country Life. Wallace also served as president of the National Conservation Congress, an advocacy organization for scientific farming, from 1910 to 1911. Energetic even in his seventies, he worked on the paper until 1916. He died unexpectedly on the speakers' platform of the United Presbyterian Laymen's Missionary Convention in Des Moines on February 22, 1916. His son Henry C. Wallace and his son Henry A. Wallace subsequently edited the paper. ${ }^{23}$ 
Publisher-editor Henry Wallace had a much different biography than the other publishers of Midwestern farm papers. Unlike Butler and Capper, he was born and raised on a farm. Unlike all of the others, he had some experience managing farms as an adult. While he did write for, edit, and own small-town newspapers before coming to agricultural journalism, his initial training was for the ministry, and he pastored Presbyterian churches for nearly fifteen years. In addition, he was the active editor of Wallaces' Farmer while also owning most of its stock. Finally, he was completely uninterested in absorbing or otherwise acquiring other publications.

Thus, there are some common themes in the lives of farm newspaper publishers. All of them came to farm journalism from general newspaper journalism: Pierce, Carroll, and Wallace from small-town papers, Butler and Capper from city newspapers. All of them also had adult careers other than farming before coming to the farm press: Pierce, Butler, and Capper in journalism; Carroll in teaching, journalism, and politics; and Wallace in journalism and the ministry. In addition, all publishers lived in the cities where their newspapers were printed: Pierce and Wallace in Des Moines, Butler in Chicago, Carroll in Sedalia, Capper in Topeka. They did not live on farms or in rural areas. While three of the five (Pierce, Carroll, and Wallace) were born and raised on farms, only Henry Wallace had farmed as an adult, and he lived in the town of Winterset and primarily managed the farming of land he owned.

Because they all came to farm journalism after owning city or smalltown newspapers, one might wonder-like Twain did in his essay-whether agricultural newspapers were a refuge for those who had failed in general newspaper journalism. For these men, however, it appears that the opposite was the case. All of these publishers were successful in their work for city and small town newspapers. Carroll, Pierce, and Wallace took the reins of larger and more lucrative operations when they moved from small-town journalism to farm journalism. Capper and Butler were successful managers of businesses that operated a number of city newspapers, but both saw an untapped market in the farms surrounding those cities. They acted to serve that market by investing in farm newspapers.

One thing is clear about all of the publishers of the farm newspapers in this study: they all were very wealthy for their time. Capper had enough money and visibility from his multiple publications to fund successful runs for Governor of Kansas in 1914 and 1916, and to be elected to the United States Senate five times between 1918 and 1948. Butler bought the Chicago radio station WLS in 1928, built a winter home in Phoenix, Arizona, and purchased the Arizona Farmer and a Phoenix radio station. According to the 1915 census, 
Henry Wallace's income for 1914 was $\$ 15,000$. This would be the equivalent of $\$ 260,000$ in 2003 . His counterpart James Pierce's income for the same year was $\$ 12,000$, or about $\$ 210,000$ in 2003 . The publishers of Midwestern farm newspapers owned significant amounts of capital and drew a significant amount of income from their publishing enterprises. ${ }^{24}$

\section{“CLOSER TOUCH WITH THE MEN AND WOMEN WHO LIVE ON FARMS": EDITORS}

The editors of the four Midwestern farm newspapers had very different backgrounds and career trajectories from their publishers. Many times in the previous discussion, the two publishers who were also editorsMatthew V. Carroll and Henry Wallace-proved exceptions to the rule. The other farm paper editors shared a number of characteristics with these publisher-editors.

Clifford V. Gregory edited the Prairie Farmer from 1911 to 1937. Like Pierce, Wallace, and Carroll, Gregory grew up in the country. He was born in October 1883 on a farm in Mount Vernon Township, Cerro Gordo County, Iowa, just outside Mason City. He was used to field work, for “as boys, he and a brother had handled much of the farm work because their father preferred carpentry to farming." 25 When he was sixteen, the 1900 census listed his occupation as "farm laborer." 26 Gregory worked his way through the Iowa State Agricultural College by writing articles about college activities for the local newspaper. He graduated with a degree in animal husbandry in 1910 and then edited the Bulletin of the Iowa State Experiment Station for a year. He became editor of the Prairie Farmer on June 1, 1911, after gaining national exposure by publishing articles in several popular magazines. ${ }^{27}$ During his tenure as editor, Gregory was instrumental in the formation of both the Illinois Agricultural Association and the American Farm Bureau Federation. ${ }^{28}$

Like the other editors, John Francis Case, who edited the Missouri Ruralist from 1913 to the mid 1950s, also came from a farming background. He was born September 30, 1876 on a farm in Lyon County, Minnesota. Several years later, his family moved to Grant County, South Dakota, where his father homesteaded land. In 1888, the family moved again, this time to a farm outside Whitesville, Andrew County, in Northwestern Missouri. ${ }^{29}$ Case began working as a printer's devil for a nearby town newspaper, the Rea Times, in 1890. During the next eight years, he worked in various capacities for several Iowa newspapers: the Blockton News, the Lorimor Journal, and the Des Moines Nonpareil. After moving back home and getting married, in 1899 he established the 
Whitesville Banner. For the next twelve years, he worked to build up both the newspaper and the town. He boosted the town's corn and poultry show tirelessly, even writing a story about it for the Missouri Ruralist in 1911. The Ruralist's editor, H. R. Nelson, got Case to write more for the paper the next year and recommended that Capper hire him as editor when Nelson quit. Capper took Nelson's advice. ${ }^{30}$

By 1913, Capper had consolidated the entire Ruralist operation into his plant in Topeka, so Case had to move to Topeka and then travel back and forth to Missouri to gather news and information. In 1915, Case bought a farm near Whitesville, informing his readers that:

As a farm owner we shall feel in just a little closer touch with the men and women who live on farms, read your helpful letters with just a little keener interest, and ask you for helpful suggestions with the same spirit of neighborliness that you ask one another. ${ }^{31}$

For the next four years, Case lived on the farm during the summer and sent his copy back to Topeka. In 1919, the Ruralist opened an editorial office in St. Louis and Case moved his family to Shady Lawn Farm Home, a small farm outside of Wright City, about fifty miles west of the metropolis. ${ }^{32}$

James Atkinson was the editor of the Iowa Homestead from 1901 to 1918. He was born in Canada in October of 1870, and came to Iowa in 1898. From 1898 to 1900 , he worked as an "Assistant in Agriculture" at the Iowa State Experiment Station in Ames. Then, for the 1901 to 1902 school year, he was a Professor in the Department of Practical Agriculture at the Iowa State Agricultural College. He had an education in agriculture, for the Iowa State College directory that lists him as a professor put "B. S. Ag." after his name. He may also have had a graduate degree of some type, for the 1915 census records that he had gone to college eight years. It appears that Pierce hired him away from Ames in 1902. He was listed on the masthead of the Homestead as "Editor-in-chief" from September 14, 1905 to July 25, 1918. A Homestead article in August 1918 said that Atkinson had resigned to buy land and settle down to farming, but he had then "realized he was needed elsewhere" during the First World War. So instead he moved to Washington, D. C. to be a "Specialist in the Marketing of Livestock" for the Bureau of Markets of the United States Department of Agriculture. ${ }^{33}$

Several characteristics of four of these five editors-Matthew Carroll, Henry Wallace, Clifford Gregory, and John Case-are apparent. All of them were raised on farms. With the exception of Gregory, all had worked for small-town newspapers before coming to agricultural journalism. In addition, Wallace and Case had managed farms as adults. Carroll and Gregory 
had both left the farm for town pursuits. While James Atkinson's birthplace and childhood home is unknown, one could safely assume that he grew up on a farm: few students took up agriculture at a state agricultural college without a farming background. Having these experiences in common with farmers, editors of farm newspapers were "closer to the farmers" they hoped to reach than the publishers of the papers. Nevertheless, while editing their respective publications, most of them lived in the city where their paper was published: Wallace and Atkinson in Des Moines, Gregory in Chicago, Carroll in Sedalia, and Case in Topeka and St. Louis. Only Case spent significant time working on a farm while editing a farm newspaper.

It is also clear that the men who were only editors of farm newspapers were not nearly as wealthy as the publishers of the papers that employed them. James Atkinson made \$4,500 editing the Iowa Homestead in 1914, or about $\$ 79,000$ in 2003 dollars. His employer, James M. Pierce, made over two and a half times as much. Burridge Butler fired Clifford Gregory over differences in approach to the paper in 1937. Gregory then hoped to start his own paper to compete with the Prairie Farmer in Illinois. A number of employees were willing to go to work for him. Unfortunately, he failed to raise the necessary capital and ended up working for a rival paper. Editors were closer to farmers than publishers in terms of income and job security. ${ }^{34}$

However, agricultural editors, like most urban professionals, made more than most farmers did. Farmers did own varying amounts of land, livestock, equipment, and other capital, and wealthy farmers most likely owned more capital than many farm newspaper editors. Farm newspaper publishers, however, owned much more capital than both farmers and editors and made much more income than any of their employees-and probably much more than any of their readers.

This examination of the editors and publishers of four lower Midwestern farm newspapers suggests that there was considerable variety among their life experiences. There was not only one identity for those who edited or published Midwestern farm newspapers. Still, some conclusions concerning the producers of farm newspapers can be drawn. The publishers of farm newspapers in the lower Midwest usually had been born and raised in towns, had written for or owned local newspapers, and had not farmed during their adult lives. They owned a large amount of capital and enjoyed a substantial annual income, and therefore they occupied a significantly different position than the readers they hoped to reach. Editors were a more varied lot. They usually had been born and raised on farms but had left the farm as adults for other pursuits. All editors were much less wealthy than publishers. They were closer to their target audience in experience and economic status. 
None of these publishers or editors can be described as the failures at regular newspaper journalism that Twain joked about in his 1870 article. If anything, the publishers of these four papers were successes at newspaper journalism who decided to concentrate on the farm market. The editors were also successes at reaching out to rural people although they did not always share the same experiences.

The locality of farm newspaper staff, however, suggests that they experienced life in a significantly different way than their readers. Since both editors and publishers lived their adult lives in large towns and cities, they were more likely than farmers to be come in contact with the proponents of a variety of reform movements at the turn of the twentieth century. They resemble the Country Life leaders described by William Bowers as "comfortably middle class" and "urban, although of rural, Midwestern antecedents." 35 They were influenced not only by their rural background but also by urban reformers.

Having explored the identities of farm newspaper editors and publishers, we now turn to the identities of farm newspaper readers. The next two chapters will investigate the readers of farm newspapers in the lower Midwest during the late nineteenth and early twentieth centuries. Chapter three will discuss what rural Midwesterners read in general and the reasons they read. Chapter four will examine the characteristics of those who read farm newspapers between 1895 and 1920. The final three chapters will then assess farm newspapers' pronouncements about social issues and how readers responded to them. 


\section{Chapter Three}

\section{"What Farmers Read and Liked":" Scenes of Reading in the Rural Midwest}

I find, through the courtesy of our postmaster, that sixty percent of the reading matter goes to the farms and forty percent to the town people. One-half of the daily papers are taken by farmers, and the Christian Herald, one of the best religious papers, has for its subscribers here seventy-five percent farmers. So we find that although there are many advantages that we who live on farms cannot enjoy, there is an inexhaustible resource and profit left us, and that is literature in our farm homes.

-Mame E. Weller, letter to Wallaces' Farmer ${ }^{2}$

Good reading is good reading alike for the farm and city, and good books and good papers will be found in more farm homes than are found in the homes of people who live in cities.

-Asa Markel, letter to Prairie Farmer ${ }^{3}$

The publishers and editors of Midwestern farm newspapers reached out to all rural Midwesterners in their areas of coverage. They claimed that all types of farmers read their publications. The accuracy of these claims needs to be established. The identities of the readers of farm newspapers, however, are best understood in the context of what rural Midwesterners read at the turn of the twentieth century. This chapter will provide this background. Chapter four will directly address the characteristics of those who read farm newspapers.

In the Midwest as well as in the Northeast, reading had become a necessity of life by the late nineteenth century. ${ }^{4}$ Midwestern farmers had eclectic tastes in choice of reading matter, and they received a number of books and periodicals that one might not expect. In general, it appears that Asa Markel was right: rural Midwesterners read many of the same types of publications 
as those who lived in towns or cities. Country people read these materials in similar ways and for similar reasons as city people. Joyce Appleby has noted that early nineteenth-century European visitors to the U. S. "repeatedly expressed amazement at the alertness of farming people." My research suggests that this intellectual acuteness continued during the next one hundred years. ${ }^{5}$ Although the authors of the quotes at the start of this chapter made claims that cannot be definitively supported or refuted, my research suggests that a majority of Rural Midwesterners did enjoy the "inexhaustible resource" that reading afforded.

\section{“I SENT 1.00 FOR HOMESTEAD”: JOHN CAMPBELL BAILEY}

On the fifteenth of January 1896, John Campbell Bailey wrote two letters. He addressed the first to the Homestead Company in Des Moines, Iowa, publisher of the Iowa Homestead. The second was for Perry Mason and Company of Boston, Massachusetts, the publisher of the Youth's Companion. He enclosed with each letter a money order for a one-year subscription to the publication; the Homestead cost one dollar, the Youth's Companion one dollar and seventyfive cents. After mailing the orders, Bailey recorded his activities in his diary: "I sent 1.00 for Homestead \& 1.75 for Youths Companion."6

Later that year, Bailey renewed his subscription to a series of other periodicals. On the twenty-sixth of February, he sent one dollar to the Butterick Publishing Company in New York City, publisher of the Delineator, a women's fashion magazine. The next day he sent three dollars and fifty cents to Collins \& Company in Philadelphia for a year's subscription to the Christian Instructor and two Bibles. In October he sent three dollars to the John R. Wilson Company for a one-year subscription to the Chicago Journal, a weekly edition of the Chicago Evening Journal. Finally, in December he paid one dollar to renew his subscription to his local newspaper, the Rock Island Union. ${ }^{7}$

Bailey lived on a farm near Coal Valley, a village in Rock Island County, Illinois. An Irish immigrant, by the late nineteenth century Bailey was an established farmer who owned slightly more than quarter section of land. He began writing detailed diaries in 1867 and continued until shortly before his death in 1923. As these examples demonstrate, his diaries reveal that he subscribed to farm newspapers, magazines, Christian periodicals, Chicago newspapers, and local newspapers. ${ }^{8}$

All across the Midwest, farmers such as Bailey bought books, sent in payments for subscriptions, and otherwise obtained reading material. They received and read farm newspapers and a number of other publications. Traces of their reading patterns can be found in their letters, diaries, account 
books, papers, and memoirs. This chapter will use such sources to outline the reading patterns of rural Midwesterners between 1895 and 1920. I examined one hundred sixty-six record groups from ten manuscript repositories in Iowa, Illinois, and Missouri. From these documents, I compiled a database of one hundred eighty five records for one hundred thirty men, forty-five women, and ten groups. (This number is larger than the number of record groups researched because some record groups provided evidence for more than one individual.) These sources came from farms in fifty-three different counties in Iowa, twenty-five counties in Illinois, and thirty-seven counties in Missouri. In these records, I looked for any mention of reading: any evidence that the individual subscribed to a periodical, bought a book, or read either. The records of ninety-seven of the one hundred seventy five individuals (fifty-four percent) and four of the ten groups provide direct evidence of specific publications that the writer received or read. Altogether these records contain 631 references to specific print materials. They mention 470 unique periodicals or books. ${ }^{9}$

English historian G. Kitson Clark advised that if you are going to generalize about a group or class, "Do not guess, try to count, and if you cannot count, admit that you are guessing." 10 This chapter will involve some counting and some guessing. First, it will present the results of my research into what farm men and women read. Then it will consider several reasons why rural Midwesterners read these books and periodicals. Finally, it will profile two Midwestern readers for whom reading was an essential part of life.

\section{WHAT RURAL MIDWESTERNERS READ}

My research provides evidence that rural Midwesterners received and/or read local newspapers, farm newspapers, national magazines, and city newspapers. Country people also read a variety of books, especially novels and religious books.

The greatest number of individuals subscribed to local newspapers: just over half of the individuals who referred to reading (forty-nine of ninety-seven) mentioned a local paper. The local paper was usually from a nearby town. For instance, Harry A. Joslyn, a farmer in DeKalb County, Illinois, paid for a subscription to the True Republican from the nearby town of Sycamore from 1877 to $1889 .{ }^{11}$ Similarly, in 1905 Charles Falor, a farmer owning over two thousand acres in Vernon County, Missouri, received an invoice from the Post Publishing Company with the following information:

The Post has on its subscription list a sufficient amount due to erect a good office building. We expect to begin that improvement relying on the friends of the paper to each make a special effort to pay the small amount due us. 
Our books show your subscription account to October 10 th is $\$ 3.00$. Thanking you for your kind patronage, and hoping that we will continue to deserve it, we remain, Yours truly, POST PUBLISHING COMPANY ${ }^{12}$

Written in pencil at the bottom of the invoice is the following: "April 12 1905 paid \$5 Paid up to October 1907." Other local publications were county-wide. In the late 1890s, Isaac N. Carr, a farmer in Washington County, Iowa, read the Washington County Press, for he copied a cure for poison ivy from that publication onto the inside of the front cover of his diary. ${ }^{13}$ Many farm families throughout the lower Midwest received a local newspaper between 1880 and 1920 .

Some farmers subscribed to papers from several nearby towns. Dan Cummins raised beef cattle, dairy cows, and hogs on one hundred and eight acres in Monona County, Western Iowa. Between 1910 and 1920, he subscribed to four different weekly papers published in small towns: the Independent of Ute, the town closest to his farm; the Times of Charter Oak, seven miles east of Ute in adjacent Crawford County; the Press of Mapleton, eleven miles Northwest of Ute, and the Times of Moorhead, nineteen miles Southwest of Ute. ${ }^{14}$ John Campbell Bailey's farm was about five miles Southeast of the Quad Cities. He received the Rock Island Union consistently from 1896 to 1919, but he also subscribed to the Moline Review-Dispatch in 1909 and 1910 and the Davenport Times from 1907 to $1910 .{ }^{15}$

Finally, several rural Midwesterners subscribed to newspapers published far from where they lived. Ozias Ferree was born in Adams County, Pennsylvania and moved to Guthrie County, Iowa in 1863. Letters to friends in Pennsylvania reveal that Ferree still subscribed to the Lancaster Examiner and that several friends regularly sent him issues of the Lancaster New Era. ${ }^{16}$ Lizzie Shale Seipp, a farmer's wife in Hampton County, Iowa, subscribed to a newspaper from her hometown of Baraboo, Wisconsin. ${ }^{17}$ While these newspapers were not "local" to Ferree and Seipp, their ties to these out-of-state communities made their papers an important part of their lives.

In the sources consulted for this project, rural Midwesterners were most likely to leave evidence that they received and read a local newspaper. Journalism historians have long described the importance of local newspapers to rural communities. ${ }^{18}$ Similarly, Christine Pawley and Gunther Barth have described the importance of local newspapers for the identity-formation of town and city people. ${ }^{19}$ Townspeople, city people, and country people all received and read their local newspaper.

On the other hand, rural Midwesterners also received farm newspapers in large numbers. These were periodicals aimed at a decidedly nonurban audience. They were referred to by forty-four of the ninety-seven 
individuals that listed specific reading materials. Farmers received national, regional, local, and specialized farm newspapers. ${ }^{20}$ Table 4 gives the names of the specific farm newspapers mentioned and the number of individuals that referred to them. Because many farmers received multiple papers, the numbers add up to more than forty-five. A number of farmers received multiple farm newspapers. John Campbell Bailey received two regional farm newspapers, the Iowa Homestead and the Western Agriculturalist, and three national farm newspapers, Farm and Fireside, Farm Journal, and Farm Press. ${ }^{21}$ Similarly, between 1905 and 1920 Dan Cummins received two regional farm newspapers, Wallaces' Farmer and the Iowa Homestead, two national farm papers, the Breeder's Gazette and the Farmer and Breeder, and one specialized farm paper, the Poland China Journal. ${ }^{22}$ Journalism student Ralph Nafziger commented on farmers' tendency to subscribe to multiple farm papers when reporting on a questionnaire he sent to one hundred Wisconsin farmers in the late 1910s. Multiple subscriptions were the norm for the fifty-one farmers who responded: none received fewer than two farm newspapers, and most received between four and eight. One even reported receiving thirty. ${ }^{23}$

Wallaces' Farmer and the Iowa Homestead were received by eleven individuals each. Wallaces' Farmer was also received by one group, the Daughters of Ceres. Chapter one noted that in the late nineteenth century

Table 4. Farm Papers Received and/or Read by Rural Midwesterners

\begin{tabular}{|c|c|c|c|}
\hline Title & $\begin{array}{l}\text { Number of } \\
\text { Individuals who } \\
\text { Subscribed/Read }\end{array}$ & Title & $\begin{array}{l}\text { Number of } \\
\text { Individuals who } \\
\text { Subscribed/Read }\end{array}$ \\
\hline
\end{tabular}

National Farm Newspapers

$8 \quad$ Capper's Farmer

Breeder's Gazette
Farm Journal
Country Gentleman
Drovers Journal
Farmer's Review
Successful Farming
Farmer's Wife
Farm and Fireside
Farmer and Breeder

Twentieth Century Farmer
Farm and Home 1

Farm Gazette 1

Farm journals $\quad 1$

Farm Press 1

Farm Progress 1

Farmer and Stockman 1

Hearth \& Home 1

Illustrated Journal of Agriculture 1

Journal of Agriculture 1

Progress Today 1 
Table 4. Farm Papers Received and/or Read by Rural Midwesterners

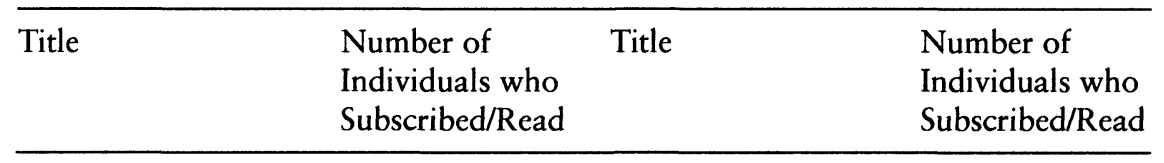

\section{Regional Farm Newspapers}

Wallaces' Farmer

Iowa Homestead

Prairie Farmer

Hoard's Dairyman

Missouri Ruralist

Orange Judd Farmer

Missouri Farmer

Northwestern Agriculturalist 2

Colman's Rural World

\section{Local Farm Newspapers}

DeKalb County Farmer 1

Elgin Dairy Report 1

Ozark Countryman

2

\begin{tabular}{lllr} 
Green's Fruit Grower & 3 & Livestock Indicator & 1 \\
American Bee Journal & 1 & National Live Stock Reporter & 1 \\
American Horse Breeder & 1 & NP News & 1 \\
American Poultry Advocate & 1 & Poland China Journal & 1 \\
Back to the Land & 1 & Poultry Culture & 1 \\
Banker-Farmer & 1 & Poultry Tribune & 1 \\
Daily Commercial & 1 & Progressive Poultry Journal & 1 \\
Drainage Journal & 1 & Stockman Journal & 1 \\
Horse \& Harness & 1 & Swineherd & 1 \\
Horse Show Monthly & 1 & Tilton Journal of Horticulture 1 \\
Horseman & 1 & Useful Poultry Culture & 1 \\
Horticultural Proceeding & 1 & Western Pomologist & 1 \\
Jersey Bulletin & 1 & Western Poultry Journal & 1 \\
Journal of Shorthorns & & & \\
\multicolumn{1}{c}{ \& Berkshires } & 1 & &
\end{tabular}

Rock River Farmer

Stockyards Nugget

(Kansas City Stockyards) 1

\section{Specialized Farm Newspapers}

Source: Database of lower Midwestern rural readers. 
and first decade of the twentieth, Midwestern farm newspapers aimed at a regional audience, not just one in their state of publication. The record groups examined give several examples of such subscribers. For instance, John Campbell Bailey of Illinois, Louis Monsees of Missouri, and John Sanborn of Missouri all received the Iowa Homestead. Monsees also subscribed to Wallaces' Farmer. ${ }^{24}$

Books ranked second in popularity among rural Midwesterners. Among the ninety seven individuals that noted specific publications, forty-five gave titles of books. Rural Midwesterners bought and/or read books on farming, religious books, novels, histories, biographies, schoolbooks, and a variety of other books. Table 5 lists the titles of the books recorded and the number of individuals that mentioned each.

The Bible was by far the most popular single title; fourteen different individuals mentioned it. This is not surprising, as the Bible is the one book Americans have consistently been most likely to own. Paul Gutjahr has

Table 5. Books Bought and/or Read by Rural Midwesterners

\begin{tabular}{lll}
\hline Title & $\begin{array}{l}\text { Number of } \\
\text { Individuals } \\
\text { who }\end{array}$ & Title \\
mentioned & & $\begin{array}{l}\text { Number of } \\
\text { Individuals } \\
\text { who }\end{array}$ \\
& & $\begin{array}{l}\text { mentioned } \\
\text { the title }\end{array}$ \\
\hline
\end{tabular}

\section{Novels}

$\begin{array}{lll}\text { Uncle Tom's Cabin } & 6 & \text { Dombey and Son } \\ \text { David Copperfield } & 3 & \text { Enoch Arden } \\ \text { Black Beauty } & 2 & \text { Esther } \\ \text { Dime novels } & 2 & \text { First Violin } \\ \text { Laddie } & 2 & \text { Five Little Peppers and How } \\ \text { Little Women } & 2 & \text { They Grew } \\ \text { Red Rock } & 2 & \text { Fools Errand } \\ \text { Redmond the Outlaw } & 2 & \text { From the Earth to the Moon } \\ \text { Tale of Two Cities } & 2 & \text { Girl of the Limberlost } \\ \text { Arabian Nights } & 1 & \text { Great Expectations } \\ \text { Ben Hur } & 1 & \text { He Fell in Love with His Wife } \\ \text { Boy Life on the Prairie } & 1 & \text { Hon. Peter Stirling } \\ \text { Captain Dieppe } & 1 & \text { Horatio Alger Stories } \\ \text { Castle Inn } & 1 & \text { House Beautiful } \\ \text { Crockett and Bowie } & 1 & \text { In the Depths } \\ \text { Daniel Deronda } & 1 & \text { Jan Vedder's Wife } \\ \text { Darius Green \& the } & & \text { Janice Meredith } \\ \quad \text { Flying Machine } & 1 & \text { Kidnapped }\end{array}$

1
1
1
1
1
1
1
1
1
1
1
1
1
1
1
1
1


Table 5. Books Bought and/or Read by Rural Midwesterners (continued)

\begin{tabular}{|c|c|c|c|}
\hline Title & $\begin{array}{l}\text { Number of } \\
\text { Individuals } \\
\text { who } \\
\text { mentioned } \\
\text { the title }\end{array}$ & Title & $\begin{array}{l}\text { Number of } \\
\text { Individuals } \\
\text { who } \\
\text { mentioned } \\
\text { the title }\end{array}$ \\
\hline
\end{tabular}

\section{Novels (continued)}

Lady of the Lake

Last of the Mohicans

Leatherstocking Tales

Seven Oaks

1

Light that Failed

Shams

Spirit Lake Massacre

Little Dorrit

St. Elmo

Lucille

Star in a Prison

1

Study in Scarlet

Luck in a Life

Taking the Bastille

Miles Standish

Temporal Power

1

Nicholas Nickleby

Thelma

Oliver Optic

Timothy's Quest

1

Oliver Twist

Out of the Depths

To Have and to Hold

Treasure Island

Trip Around the World

Twice Told Tales

Walter Scott's Works

Wedding Garments

When a Man's a Man

When Knighthood was in Flower

Woman of Kronstad

Wormwood

Yolanda

Progress and Poverty 1

Put Yourself in His Place 1

Ramona 1

Rollo in Europe 1

Romance of 2 Worlds

\section{Books about Farming}

USDA Publications List

How to Test Seed Corn

Animal Industry

Prairie Farmer's Poultry

Aurora Daily News

Book

Farm Atlas

Henry's Feeds and Feeding

USDA Soil Survey of Bates

County Missouri

\section{Christian Books}

Bible

Pilgrim's Progress

Paradise Lost

445 Difficult Bible Questions

Answered

Biblical Antiquities 
Table 5. Books Bought and/or Read by Rural Midwesterners (continued)

\begin{tabular}{lll}
\hline Title & $\begin{array}{l}\text { Number of } \\
\text { Individuals }\end{array}$ & Title \\
who & & Individuals \\
mentioned & & who \\
the title & mentioned \\
& & the title \\
\hline
\end{tabular}

\section{Christian Books (continued)}

Building with India 1

Choir Invisible 1

Christian Herald Almanac 1

Church books 1

Foxe's Book of Martyrs 1

Fundamentals 1

Girl and her Religion $\quad 1$

Gordon Keith 1

History of Spiritualism, Ancient and Modern 1

In the Coils

Life of Christ

$\begin{array}{ll}1 & \text { Light in the Clearing } \\ 1 & \text { Olive Plants } \\ 1 & \text { Right of Way } \\ 1 & \text { Roads to the City of God } \\ 1 & \text { Scofield Bible } \\ 1 & \text { Speaking to the Heart } \\ 1 & \text { Three-Fold Secret of the } \\ 1 & \text { Holy Spirit } \\ 1 & \text { Truth vs. Theology: A } \\ 1 & \text { Discussion with } \\ 1 & \text { Dr. Bushnell }\end{array}$

\section{History and Biography}

Around the World with Philip Phillips

Biographical Dictionary

Inside Story of the White of Leading Men in

St. Louis House

Jones School History of the

Biography and History of

Life and Journals of Louisa America May Alcott

Bryan's Speeches

Camp Fires of the Confederacy

Confederate Soldier in the Civil War, 1861-1865

Life of Garfield

Memoirs of Gen. Joseph T. Johnston

One Man's Life

Our New West

Greatest Wonders of the World

\section{Standard History of} the World

1

\section{Other Books}

School books (generic reference)

Dictionary 
Table 5. Books Bought and/or Read by Rural Midwesterners (continued)

\begin{tabular}{|c|c|c|c|}
\hline Title & $\begin{array}{l}\text { Number of } \\
\text { Individuals } \\
\text { who } \\
\text { mentioned } \\
\text { the title }\end{array}$ & Title & $\begin{array}{l}\text { Number of } \\
\text { Individuals } \\
\text { who } \\
\text { mentioned } \\
\text { the title }\end{array}$ \\
\hline
\end{tabular}

Other Books (continued)

Armour's Monthly

Cook Book

By-Laws of York Lodge

Constitution of the

National Farmers'

and LaborersUnion

of America

Daughters of Ames

Cookbook

Encyclopedia Britannica

Fourth Grade Reader

Grange Manual

Graves' Manual of

Parliamentary Rules

Hoosier School Boy

Hoosier School Master

Inferno

Lamb's Tales from

Shakespeare

Laws of Iowa Passed at the 35th General Assembly

Manual of Parliamentary Practice
1

1

1

1

1

1

1

1

1

1

1

1

1

1
Missouri Anti-Horse

Thief Association

Constitution

Missouri Anti-Horse

Thief Association

Proceedings

Missouri Anti-Horse

Thief Association

Ritual Book

Missouri Masonic

Monitor

Modern Woodmen of

America By-Laws

Oliver Wendell Holmes'

Poems

Origin of Species

People's Home Library

Medical Book

Physical Geography

Polar and Tropical

Worlds

Ropp's Commercial

Calculator

Shakespeare's Plays
1

1

1

1

Source: Database of lower Midwestern rural readers

described nineteenth century efforts to put a copy of the good book in every American's home. ${ }^{25}$ Other Christian books such as Pilgrim's Progress, Foxe's Book of Martyrs, and a number of Christian novels are also mentioned in the records. S. A. Paul, a farmer in Marshall County, Iowa, purchased 445 Difficult Bible Questions Answered and the ten-volume set The Fundamentals, the publication from which Fundamentalism received its name. ${ }^{26}$

Six different readers mentioned Uncle Tom's Cabin, the largest number for a single work of fiction. The popularity of Uncle Tom's Cabin among 
Iowa townspeople was also noted by Christine Pawley. ${ }^{27}$ More than one reader also mentioned David Copperfield, A Tale of Two Cities, Little Women, and Black Beauty. The works of Charles Dickens are especially well represented in the records, and other well-known and obscure works complete the list. Sarah Jane Kimball of Jones County, Iowa, noted reading the popular novels Uncle Tom's Cabin, Ramona by Helen Hunt Jackson, and St. Elmo by Augusta Jane Evans. ${ }^{28}$ In addition, several writers referred to dime novels as a group, and a number of titles appear to have been representatives of this type of cheap fiction, including Redmond the Outlaw, Darius Green and the Flying Machine, and Crockett and Bowie. Country people's ownership of the Bible, popular fiction, and dime novels was very similar to the ownership patterns of readers in small towns and cities. ${ }^{29}$

Several farmers mentioned owning or reading publications about farming. The United States Department of Agriculture Publications list was a pamphlet that listed publications farmers could order free of charge from the USDA. A copy of this list was saved with the papers of both James $\mathrm{H}$. Beed and Isaac N. Carr. ${ }^{30}$ Rural Midwesterners also referred to histories of the United States, school textbooks, ritual manuals for secret societies, and reference works such as dictionaries.

A significant number of rural Midwesterners received and/or read magazines. Magazine titles were referred to by thirty-five of the ninety-seven individuals who mentioned specific reading materials. A number of readers received several different magazines. On December 21, 1899, John A. Sanborn of Holt County, Missouri, recorded in his diary payments for subscriptions to Ladies Home Journal, Youth's Companion, and Munsey's Magazine. Four years later, he listed payments for The Delineator, Youth's Companion, The Saturday Evening Post, and Woman's Home Companion. ${ }^{31}$ In a circular letter to her family in 1910, Lucy White listed a number of magazines:

We are having lots to read-Good Housekeeping, The Outlook, and lots of others. I am reading Mrs. Prentiss's American Motherbood. It is the best Mother's Magazine I know of. The last [Ladies] Home Journal seemed uncommon full of good things. ... Do you read the articles by the Country Contributor in the [Ladies] Home Journal? I think she is very fine and sociable. ${ }^{32}$

The "Country Contributor" wrote a monthly column titled "The Ideas of a Plain Country Woman." ${ }^{33}$ Living on a farm did not preclude receiving and enjoying the most popular magazines of the period.

Table 6 lists all of the magazine titles mentioned and the number of individuals who referred to them. It includes nearly all of the major magazines 
in the late nineteenth and early twentieth centuries. In the late nineteenth century, three standard literary magazines were popular: the Atlantic, mentioned by three individuals; Harper's Monthly, mentioned by five individuals; and Harper's Weekly, mentioned by three individuals. The early twentieth century saw multiple references to Ladies' Home Journal, the first magazine to reach one million subscribers, the Outlook, a New York City reform journal with which Theodore Roosevelt was associated after 1908, and the Saturday Evening Post. Three individuals mentioned the Journal, two the Outlook, and four the Post. Christopher Wilson has noted

Table 6. Magazines Received and/or Read by Rural Midwesterners

\begin{tabular}{|c|c|c|c|}
\hline Title & $\begin{array}{l}\text { Number of } \\
\text { Individuals } \\
\text { who } \\
\text { Subscribed/ } \\
\text { Read }\end{array}$ & Title & $\begin{array}{l}\text { Number of } \\
\text { Individuals } \\
\text { who } \\
\text { Subscribed/ } \\
\text { Read }\end{array}$ \\
\hline Youth's Companion & 8 & Home Maker & 1 \\
\hline Harper's Monthly & 5 & Housekeeper & 1 \\
\hline Delineator & 4 & Ladies' Repository & 1 \\
\hline Harper's Weekly & 4 & Lady's Home Companion & 1 \\
\hline Ladies' Home Journal & 4 & Leslie's Illustrated Weekly & \\
\hline Saturday Evening Post & 4 & Newspaper & 1 \\
\hline Atlantic & 3 & Metropolitan Magazine & 1 \\
\hline McClure's & 3 & Mother's Magazine & 1 \\
\hline Everybody's & 2 & Munsey's & 1 \\
\hline Ladies World & 2 & National Geographic & 1 \\
\hline National Magazine & 2 & National Tribune & 1 \\
\hline Outlook & 2 & Pilgrim & 1 \\
\hline Woman's Home Companion & 2 & Public & 1 \\
\hline World's Work & 2 & Public Opinion & 1 \\
\hline American Monthly Magazin & ne & Red Cross Magazine & 1 \\
\hline American Motherhood & 1 & Review of Reviews & 1 \\
\hline American Road Maker & 1 & Saturday Journal & 1 \\
\hline Arcadian Magazine & 1 & St. Nick & 1 \\
\hline Association Monthly & 1 & Vicks Magazine & 1 \\
\hline Better Homes and Gardens & 1 & Waverly Magazine & 1 \\
\hline Cosmopolitan & 1 & West at Work & 1 \\
\hline Good Housekeeping & 1 & Woman's Magazine & 1 \\
\hline Hearst's & 1 & Woman's World & 1 \\
\hline
\end{tabular}

Source: Database of lower Midwestern rural readers. 
a shift in circulation from older publishing house publications such as Atlantic and Harper's to new, less literary, mass-market magazines during the period. ${ }^{34}$ While Wilson's article deals with urban readers in the Midwest, my research suggests that this shift occurred in rural areas as well: references to the former magazines decreased in the early 1900s, while references to the latter increased.

During the years between 1880 and 1920, however, the most popular magazine among these readers was the Youth's Companion. Eight different individuals mentioned it. This magazine, published by the Perry Mason publishing company, had been started in 1827 as a magazine for Christian youth. By the late nineteenth century, it printed both fiction and non-fiction that appealed to the entire family. Non-fiction contributors included Grover Cleveland, Robert E. Peary, Theodore Roosevelt, and Booker T. Washington, while Louisa May Alcott, Frances Hodgsdon Burnett, and Jack London contributed fiction. The Youth's Companion was popular among rural and urban readers alike. ${ }^{35}$ Country people received the same magazines as townspeople and city people in the Midwest at the turn of the twentieth century.

Thus far this chapter has noted that, besides publications aimed directly at farmers, country people received and read the same types of publications as city people. In addition to these similarities, a significant number of rural Midwesterners received newspapers from cities themselves. Titles of urban newspapers were mentioned by a third of individuals that referred to specific publications (thirty-three out of ninety-seven). Some country people probably treated these city newspapers as their local newspapers. Harry A. Joslyn and Laura Whitney Cooper lived in northern Illinois and received Chicago daily newspapers. While John A. Sanborn lived in Northwestern Missouri, he received both the Kansas City Journal and the Kansas City Star. ${ }^{36}$ Rural Midwesterners who lived close to an urban area often subscribed to a newspaper from that city.

However, other farmers who received a local, small-town newspaper also received a newspaper from the regional metropolis. For instance, I. N. Carr of Washington County, Iowa received the Washington County Press, the Cedar Rapids Gazette, and the Chicago Weekly News. Ralph Allen of Tazewell County, Illinois, received both the local Delavan Times-Press and the New York American. Finally, John M. Inman, a farmer in Worth County, Iowa, subscribed to the San Francisco Chronicle because he owned land in California. ${ }^{37}$ Other rural Midwesterners received newspapers from Des Moines, Kansas City, St. Louis, or Sioux City. Table 7 gives the titles of all 
city newspapers mentioned, along with the number of individuals that referred to them. Country people helped to swell the subscription lists of weekly editions of urban newspapers.

A small number of rural Midwesterners received several other types of periodicals. Eleven individuals referred to Christian periodicals. John Campbell Bailey subscribed to the Christian Instructor regularly between 1880 and 1915; he also received the United Presbyterian and the Evangelical Repository. ${ }^{38}$ Lucy Van Voorhis White reported in her letters that she read the Christian Herald, Christian Union, and Sunday School Times. ${ }^{39}$

Finally, ten individuals mentioned what might be called specialized periodicals. For instance, Charles Falor, who owned interests in mining companies

Table 7. Newspapers from Large Cities Received and/or Read by Rural Midwesterners

\begin{tabular}{lll}
\hline Title & Number of Title & Number of \\
Individuals & & Individuals \\
who & & who \\
& Subscribed/ & Subscribed/ \\
& Read & Read \\
\hline
\end{tabular}

$\begin{array}{ll}\text { Cedar Rapids Gazette } & 1 \\ \text { Cedar Rapids Journal } & 1 \\ \text { Chicago Daily News } & 1 \\ \text { Chicago Evening Journal } & 2 \\ \text { Chicago Inter Ocean } & 5 \\ \text { Chicago Journal } & 3 \\ \text { Chicago Post } & 1 \\ \text { Chicago Times } & 2 \\ \text { Chicago Tribune } & 4 \\ \text { Chicago Tri-Weekly } & 2 \\ \text { Chicago Weekly News } & 1 \\ \text { Daily Graphic } & 2 \\ \text { Denver Post } & 1 \\ \text { Des Moines Capital } & 1 \\ \text { Des Moines Leader } & 1 \\ \text { Des Moines Register } & 3 \\ \text { Des Moines Register \& Citizen } & 1 \\ \text { Des Moines Register and Leader } & 1 \\ \text { Kansas City Journal } & 1 \\ \text { Kansas City Star } & 2\end{array}$

$\begin{array}{ll}\text { Kansas City Times } & 1 \\ \text { New York American } & 1 \\ \text { New York Herald } & 1 \\ \text { New York Ledger } & 1 \\ \text { New York Sun } & 2 \\ \text { New York Tribune } & 1 \\ \text { Town Topics (New York City) } & 1 \\ \text { Omaha Bee } & 2 \\ \text { San Francisco Chronicle } & 1 \\ \text { Sioux City Journal } & 2 \\ \text { Sioux City Post } & 2 \\ \text { Sioux City Tribune } & 1 \\ \text { St. Louis Daily News } & 1 \\ \text { St. Louis Globe-Democrat } & 4 \\ \text { St. Louis Journal } & 1 \\ \text { St. Louis Post-Dispatch } & 1 \\ \text { St. Louis Republic } & 1 \\ \text { St. Louis Star-Democrat } & 1 \\ \text { St. Louis Times } & 1 \\ \text { Toledo Blade } & 2\end{array}$

Source: Database of lower Midwestern rural readers. 
in Bates and Vernon counties, Missouri, received the Weekly Mining Review from 1897 to 1902. In addition, Winifred Davis Cornett, a farmer's daughter and teacher in Linn County, Missouri, paid for Teacher's Magazine in 1908. ${ }^{40}$ Nehemias Tjernagel, a farmer in Hamilton County, Iowa and son of immigrants from Norway, received several foreign language periodicals: Skandinaven, Samband, and Sanger-Hilsen. ${ }^{41}$

None of the record groups examined mentioned temperance or prohibition literature. The many works of Frances Willard are not found among these Midwesterner's records. While Uncle Tom's Cabin was immensely popular, Harriet Beecher Stowe's Temperance Tales is not cited. The Women's Christian Temperance Union's magazine The Union Signal is not mentioned. The absence of temperance literature is striking given the widespread support for temperance reform in rural areas of the country during the Progressive era. This could mean that temperance was less of a concern to Midwestern farmers than has previously been believed. Alternatively, it may be just a result of the individual record groups examined. ${ }^{42}$

Rural Midwesterners who left behind records of their reading referred primarily to local newsspapers, farm newspapers, city newspapers, and a variety of books and magazines. The types of publications they bought and read were very similar to what their counterparts in urban areas were reading at the time.

\section{GENDER AND READING}

The record groups examined also provide information on the reading patterns of a significant number of women. A quarter of the individuals in the database were women-forty-five of one hundred seventy-five. In addition, almost a third of the individuals that referred to specific publications were women (thirty out of ninety-seven). Finally, a higher proportion of women referred to reading specific publications. While two thirds of the women mentioned reading, only just over one half of the men did-thirty out of forty-five women, sixty-seven of one hundred thirty men. Women have furnished many of the examples given above for the various types of reading material bought and read. Patterns of farm women's reading show both similarities and differences from men's.

Table 8 gives the number of references to types of reading matter by gender. Since I looked at more documents written by men than by women, it is reasonable that for most types of reading materials, instances in men's records outnumber those in women's. It is striking, therefore, that women made seventy-two of the ninety-two references to novels in the database (seventy-eight percent). Looking at it by readers rather than by references to reading, seventeen of the thirty female readers (fifty-seven percent) referred to the title of at 
Table 8. References by Rural Midwesterners to Types of Publications by Gender

\begin{tabular}{lll}
\hline Type of Publication & $\begin{array}{l}\text { Times Mentioned in a } \\
\text { Record Written by a Man }\end{array}$ & $\begin{array}{l}\text { Times Mentioned in a } \\
\text { Record Written by a Woman }\end{array}$ \\
\hline
\end{tabular}

$\begin{array}{lll}\text { Local Newspaper } & 91 & 18 \\ \text { Farm Newspaper } & 108 & 30 \\ \text { Magazine } & 49 & 34 \\ \text { City Newspaper } & 50 & 12 \\ \text { Book } & 89 & 109 \\ \quad \text { Christian } & 22 & 19 \\ \quad \text { Farming } & 9 & 0 \\ \quad \text { History/Biography } & 11 & 5 \\ \text { Novel } & 20 & 72 \\ \text { Other (poetry, school, etc.) } & 27 & 13\end{array}$

Source: Database of lower Midwestern rural readers.

least one novel. All six of the individuals who mentioned Uncle Tom's Cabin were women. In contrast, only nine of the sixty-seven male readers (thirteen percent) referred to a novel. It appears that rural women read more fiction than men did. This observation agrees with those of Cathy Davidson and Christine Pawley that women read novels much more than men. ${ }^{43}$

In addition to the greater number of novels read by women, it also appears that women wrote more about what they read than men did. The records that provide information about men's reading are mainly diaries, account books, and invoices and receipts. Furthermore, information in diaries is often notations of subscriptions and payments. By contrast, evidence about women's reading comes primarily from diaries and letters, both of which provide much narrative information. Women described what they read, often in great detail. Lucy White wrote the following to her fiancé in 1896:

I did not try to work any after supper and have just finished my book "Jan Vedder's Wife." I found in it some things about us-in the last of the story, where Jan and his wife came together and were happy again after a long estrangement and separation. I do not mean that could possibly apply to us, but some of the things said of them. I found this: "Nothing is so conducive to a strong affection as a long, sweet course of love-letters." 44

Therefore the large number of novels read by women in the database could be because women were more likely to record what they read than men. Still, since the preponderance of women's novel reading is very large, it appears that rural women read more novels than did rural men. 
Finally, in assessing the other figures in Table 8, one should remember that women probably read many of the publications listed in men's diaries and account books. John A. Sanborn listed subscriptions to magazines aimed at women in his diary: Ladies' Home Journal, the Delineator (a fashion magazine), Home Maker, and Woman's Home Companion. As he was married and had at two daughters, the women in his household were certainly the primary readers of these magazines. It is likely that husbands and wives also shared other reading material. Sanborn also paid for subscriptions to Munsey's and the Saturday Evening Post, both magazines that appealed to both genders. ${ }^{45}$ Laura Gibson Smith tells of how both she and her husband read the Post from cover to cover. ${ }^{46}$ Farm newspapers also usually had departments for women. For all these reasons, it cannot be assumed that only men used the local newspapers, magazines, farm newspapers, and city newspapers listed in men's records.

In sum, it appears from my research that rural women read some of the same things as men, that women read more novels than men, and that they wrote in greater detail about their reading than men. It is possible that much of the money spent by rural households on reading materials-and the time spent by rural families on reading-was determined by the attitudes of the women in the household.

\section{WHY RURAL MIDWESTERNERS READ}

These sources do not only provide evidence of what rural Midwesterners read. They also suggest reasons why country people read these publications. It appears that country people read for at least three reasons: to build and maintain their communities, to entertain themselves and their families, and to gain useful information for their lives.

Historians of print culture have long maintained that communities use print publications to build and maintain their membership. ${ }^{47}$ The records show evidence that country people participated in a number of communities supported by printed materials. The most basic was the geographic locality or local community. The large proportion of readers who received or read a local paper suggests that they were interested in local news. In fact, several rural Midwesterners saved news clippings and put them into their diaries or account books. Others saved them in scrapbooks. These clippings were usually articles about family or friends cut from the local newspaper. Laura Whitney Cooper and Jay Linn Torrey both kept such scrapbooks. ${ }^{48}$

In addition, some country people described happenings they had learned from their local newspapers in their diaries and letters. For instance, S. A. Paul noted major events in the lives of acquaintances in his diary: "I read in the 
Gilman dispatch [sic] yesterday that Hiram Showalter was dead and was buried in the Rushville cemetery" and "I read in the Gilman Dispatch of May 3 that William Paul['s] Son Joseph and Miss Maude Pickering of Marshall towwn [sic] were married in the latter city at three o'clock Wednesday April 25th." ${ }^{49}$ Lucy White told her family about local events in her letters. In one she said she enclosed a clipping from the local Dallas Center Times about a notorious neighbor who had been arrested for killing his wife:

I will enclose a clipping from last week's Times, about our neighbor, Cal Brewer. We are all feeling so badly about it for it looks like the penitentiary for him. His wife had pneumonia last summer but got well against his own wish it seemed. There are four little ones, the oldest five last summer. He seems to be a black sheep. ${ }^{50}$

Many country people subscribed to local newspapers to follow the activities of their local community.

As Lucy White kept her family informed of events in her community through print, so other rural Midwesterners used print publications to keep in touch with previous communities where they had lived-even when they had moved far away. Ozias Ferree juggled newspapers to keep up with both his community of birth in Pennsylvania and his adopted community in Iowa. He repeatedly thanked friends in Pennsylvania for sending him the Lancaster New Era. But he pondered the amount of reading material he received in a letter in 1887 :

I get to read the "Lancaster Examiner" weekly, but there are few names in it that are familiar to us. We get many papers-and more than time will permit us to read; in the last year we got on an average five papers dailyIn Des Moines, there are 52 papers and periodicals published-and many are dailies-and about every village in this county supports a paper. $^{51}$

It appears that his desire to follow the news of a variety of communities sometimes exceeded the time he had to spend on reading. The ties to his home community apparently went even further than just reading Pennsylvania newspapers, however. In 1889, he and his wife traveled to Pennsylvania to visit Lancaster County and Philadelphia. Apparently while in Philadelphia, they visited with the editor of a local paper: "Monday we returned to the City, got our tickets, and transacted other business, then went to the navyyard [sic] where we met our Editor of the 'Gettysburg Sentinel.' We spent an hour very pleasantly." 52 Was this just a personal visit? Or did the editor interview them for his newspaper so that it could report on a local family who had moved west? It is unclear. What is clear is that ties 
between communities in Iowa and Pennsylvania were maintained with the help of local newspapers.

It appears that some rural Midwesterners attempted to follow community events in several local communities. Dan Cummins subscribed to four different weekly newspapers published in four different small towns: the Ute Independent, the Charter Oak Times, the Mapleton Press, and the Moorhead Times. In addition, he also paid for a subscription to the Sioux City Journal. Sioux City was the closest city of any size. The Mapleton and Sioux City papers were Republican, the Moorhead paper was Democratic, and the Ute and Charter Oak papers were independent. While these were most likely not large papers, one can imagine them piling up over the course of several months. Cummins does not tell us if he read all of these papers or why he received them. One can imagine, however, that the party affiliation of the paper was less important to Cummins than the news of the local communities around him.

Some rural Midwesterners formed communities for the express purpose of reading. James R. Howard remembered briefly the forming of a reading club with other neighborhood farmers during the winter:

One winter a small group of us organized a reading club. It so happened
that on the night we organized the aurora borealus [sic] was in full play.
We named the organization the Liberty Northern Light Reading Club.
That winter we read and discussed Pilgrim's Progress, Scott's Lady of
the Lake, and David Copperfield. 53

Such reading clubs for self-improvement and culture were an integral part of life in rural areas as well as towns and cities. ${ }^{54}$ The college-educated Howard later became the president of the Marshall County Farm Bureau, the Iowa Farm Bureau Federation, and the American Farm Bureau Federation. ${ }^{55}$

Finally, one local community was based not only on geography but also on gender and shared interests. One of the groups studied, the Walnut Chapter of the Daughters of Ceres, subscribed to Wallaces' Farmer in 1902. ${ }^{56}$ This group was a women's club formed in 1898 in Polk County, Iowa. Nancy Cantwell Wallace, wife of the first Henry Wallace and editor of the "Hearts and Homes" department of Wallaces' Farmer, was a friend of a number of the members of the chapter and often attended its meetings. She was also the president of the state organization of the Daughters of Ceres. In addition, the secretary of the Walnut Chapter described Wallaces' Farmer as the "official organ" of the club, because Nancy Wallace publicized the activities of the various chapters in her department. ${ }^{57}$ This farm newspaper supported the community of women represented by the Daughters of Ceres 
by encouraging the formation of more clubs statewide and promoting their activities. The club used the periodical to further its existence and goals. Chapter seven will consider women's communities of print in more detail.

City people used local newspapers for community building purposes much as country people did. Gunther Barth and Thomas Leonard have described city people's use of newspapers for local news, for orienting oneself within one's community, and for shaping one's identity. Women's clubs and reading clubs were also central sites for reading in the town of Osage, Iowa at the turn of the twentieth century. Townspeople, city people, and rural people all used print publications for community building in similar ways in the late nineteenth and early twentieth centuries. ${ }^{58}$

Rural Midwesterners also commonly read for enjoyment during their leisure time. During the winter, darkness came early, there was less farm work to do, and cold and snowy weather often kept families inside evenings. Between December and February, therefore, many farm families gathered in the living room while one member read. Sarah Jane Kimball was a single farm woman living with her brother on a Jones County Farm in the late nineteenth century. In January of 1900 she noted in her diary: "Days getting so short there is little time to do much only the housework. I have long evenings to sew while Merrill reads. Just now he is reading 'Shams' by Uncle Ben Morgan." 59 Kimball's diaries are full of such references to reading for pleasure. In the 1870s, her brother read aloud Uncle Tom's Cabin and The Polar and Tropical Worlds. They also enjoyed the accounts of the Beecher-Tilton trial in the New York Ledger. In the 1880s, the family read Uncle Tom's Cabin again, as well as items from several newspapers. In the 1890 s, the family read a number of domestic novels, including Ramona, Thelma, Romance of Two Worlds, and St. Elmo. Kimball also records reading to herself. She read Longfellow's Miles Standish and The Life and Journals of Louisa May Alcott between chores. During these years before the Sears catalog and rural free delivery, Kimball ordered books from Wanamaker's department store and had them delivered by express to the nearest town. ${ }^{60}$

Mary H. O'Neill of DeKalb County, Missouri, was still living with her parents in 1899, even though she was twenty-four years old. She recorded in her diary a variety of different family activities centered on reading for enjoyment:

Read almost all of "A Star in a Prison" to Grandma. . . . Papa read article [sic] on Wyandotta cave tonight. . . . Mama read aloud an account of Countess Schimmelman's Sailors' Relief Work on the Baltic Sea and in Chicago. ... Read aloud Miss Parloa on "Country Life in France" in 
the evening. ... Enjoyed the new Ladies Home Journal in the evening. ... Read aloud from McClure's magazine in the evening. ... Papa read aloud "A Luck in a Life."61

She also noted when she did not enjoy her reading: "I read 'The Castle Inn' by Stanley Wyman today and don't like it a little bit."62 O'Neill described different members of the family reading aloud to diverse audiences. The family enjoyed both fiction and non-fiction, both books and magazines. Reading helped the O'Neill family to pass winter evenings in places far away from Northern Illinois. Rural Midwesterners, like their counterparts in towns or cities, read for pleasure. ${ }^{63}$

Finally, rural Midwesterners read both local and farm newspapers for their useful information. Sometime in late 1897 or early 1898, Isaac N. Carr, a farmer in Washington County, Iowa, wrote the following on the inside of the back cover of his diary: "Cure for Ivy poison in an hour bathe in a solution of sodium hyposulphite taken from Washington Co. Press of September 22 1897." 64 Carr often wrote useful information into his diary. On Sunday, November 24, 1895, he copied a "Rect [sic] to clear Seed Potatoes from Scab taken from the Iowa Homestead of November 22 1895" into the front of his diary. Carr copied a number of agricultural recipes into his diaries, including a "Cure for big jaw in cattle," a "Recipe to kill lice on stock," and "A disinfectant $\&$ vermin destroyer for hogs." 65

Women as well as men sought work-related information. While farm newspapers provided separate departments for women on housekeeping and other topics, women often read farm newspapers for information about farming topics. Lucy White, like many Midwestern farm women, ran a thriving poultry business. She wrote to her family that she read articles, probably in farm newspapers, in order to make better use of her new incubator: "We are very much gratified at my success and read all the incubator articles we find." Several years later, she decided against raising squabs after reading up on the subject. ${ }^{66}$ She most likely agreed with the pronouncement of Wallaces' Farmer about women's poultry-keeping and farm newspapers:

Every woman who undertakes the business of poultry raising can dress herself well, keep her purse supplied with pin-money, and see the pinmoney grow into a bank-book. Poultry literature is playing a prominent part in the advancement of poultry culture for profit. It is a business that has become popular as well as profitable, and people love to read about it and are interested. ${ }^{67}$

Rural men and women read farm newspapers to obtain information they could apply to their work in the fields, in their farm yards, and in the home. 


\section{“I DIDN'T LIKE IT SO WELL AS TREASURE ISLAND": INDIVIDUAL READERS}

So far this chapter has dealt with aggregate numbers and glimpses of reading afforded by country peoples' records. But a number of individual rural Midwesterners left behind useful collections for the study of reading. This section will examine two of these rural readers: Lucy Van Voorhis White and John A. Sanborn. While their records illustrate some of the reasons outlined above, they also reveal motivations that were unique to their own situations. The two represent two stories among many of how country people interacted with printed materials.

Lucy D. Van Voorhis was born on May 8, 1869 in Grundy County in Central Iowa. She grew up on her family's farm with her five sisters and one brother. After graduating from high school she taught in several rural schools. In 1896 she Married George T. White and moved to his farm in Dallas County, Iowa. Most of her brothers and sisters had also moved away from the family home, so to keep in touch, they initiated a circular letter. A packet of letters from each child and their mother was sent from one member of the circle to the next. When the packet arrived, each writer removed his or her own letter, wrote a new one, and sent on the packet. In this way, Lucy White saved the letters she wrote along with her other correspondence. The Iowa Women's Archives is the home for over twenty-five years of that correspondence, from 1907 to 1933.

The Whites raised corn, hay, oats, and wheat on their farm. They also fed cows, hogs, and chickens. They farmed one hundred sixty acres, and according to the 1915 Iowa Census they made fifteen hundred dollars profit in 1914 (about $\$ 26,000$ in 2003). ${ }^{68}$ The three children and the eighty-five chickens were Lucy's responsibility, as they were on most Midwestern farms. ${ }^{69}$ In 1908 George purchased an incubator so that Lucy could expand her poultry operation, and she noted in a letter that she was looking for articles about incubators to help her handle the new machinery. The next year she bought a brooder and started advertising eggs and cockerels for sale. In 1910 she reported selling forty-five dollars worth of eggs. Later, she wrote of wanting to raising squabs for a business but then deciding that it could not be done on a small scale. She had done some research on the topic: "We sent for a government bulletin." Lucy referred to the chickens less in her letters after 1912, perhaps because she had downsized the operation, perhaps because it was just no longer new and exciting news for her family. ${ }^{70}$ It remains clear that White read farm newspapers and other materials for useful information she could put to work in her poultry operation.

Lucy White also told her family about the novels she had read. In 1907 , she reported that she had read Kidnapped by Robert Louis Stevenson. 
In 1914, she wrote that she had read A Tale of Two Cities and was looking for history books to supplement her knowledge of the French Revolution. The next year it was Pollyanna. Two years after that she read Yolanda and When a Man's a Man. It appears that she read all of these books for pleasure, for she gave her family suggestions on whether to read them or not. For instance, she tells them that she enjoyed Kidnapped, but "I didn't like it so well as Treasure Island." Of the two books she read in 1917, she noted "Neither of them long and both worth reading." It appears that the other members of her family provided similar comments about their reading. They conducted an intermittent family reading club in the circular letters. ${ }^{71}$

In addition to novels, White read a variety of Christian works. She belonged to the local Methodist church and taught Sunday school there. In 1910 she mentioned reading the Sunday School Times and Christian Union, weekly papers published in Philadelphia and Des Moines, respectively. In 1916, she informed her family that she had subscribed for the Christian Herald, a New York weekly. She was no longer teaching Sunday school and therefore thought that the Herald was more appropriate than the Sunday School Times. In between, she noted that she read The Story of Jerry McAuley, a biography of the founder of the New York City Rescue Mission. ${ }^{72}$ She said that "it reads tame after Billy Sunday." She also told her family of her reading in the Bible: "I read Judges and Ruth each three times and will soon finish the Samuals [sic]." In 1920, she happily informed them that she was having a book sent to each member of the family:

I have been reading "The Three-fold Secret of the Holy Spirit," a little book that is published for free distribution and given away to anyone who asks for it. I sent some money (it is published by voluntary contributions) and asked that a copy be sent to each family in the circle for I liked it so much. It is excellent to read in the family devotions, for it is easy to understand. I have two other books by the same writer.

The writer was Rev. James H. McConkey of Pittsburgh. ${ }^{73}$

Lucy Van Voorhis White was busy farm woman, an avid reader, and a consistent letter-writer. She read local newspapers for their useful information, farm newspapers for their news of community events, and novels for pleasure. She also subscribed to periodicals and read books to support her Evangelical Protestant faith.

John A. Sanborn's diaries from 1899 to 1907 have been stored and maintained by the Western Historical Manuscript Collection in Columbia, Missouri. The diaries themselves are small-about four inches by six inches-but they provided a page per day for Sanborn to record the weather, 
his activities for the day, any financial transactions undertaken, and brief comments. These nine years of diaries offer a window on Sanborn's use of print publications. Reading was a central part of his life.

When the census taker came to the Sanborn's farmhouse in Holt County, Northwestern Missouri in 1900, there were five people living there. The family had moved to this farm near Mound City the previous year. John Sanborn was fifty years old, and his wife Emma was forty-three. Both had been born in Illinois, and they were married in 1882. They had three children: Ethel, who was eighteen years old, Edith, who was thirteen years old and attending school, and Willie, who was five years old. The family owned one hundred and fifty acres on which they grew corn, oats, and potatoes. John also cared for several cows and hogs. A number of the family's acres were brush that provided them with firewood. Finally, several apple trees provided apples they made into apple cider and apple butter. ${ }^{74}$ John summarized the year 1899 as follows:

The year closes on our 1 st year in mo. [sic]

Finds us in good health and spirits

We have not made much money, but I believe I can sell out and show a gain of $\$ 1500.00$ in the year, my land is worth more than I gave for it. I owe a good deal but can show value for it. ${ }^{75}$

During 1899, a number of periodicals entered the Sanborn home. On January 14 he ordered the Orange Judd Farmer, Chicago Inter Ocean, the Kansas City Star, St. Louis Star-Democrat and the Youth's Companion. He paid for these all at once, probably taking advantage of a subscription club offer from one of the papers. Thus, Sanborn subscribed for a Midwestern farm newspaper, three city newspapers from regional metropolises, and a popular magazine. The next year he subscribed for a similar selection of publications: the Mound City News, the Orange Judd Farmer, the Chicago Inter Ocean, the Kansas City Journal, the Omaha Bee, Ladies' Home Journal, Munsey's Magazine, and the Youth's Companion. This purchase represented an investment in the local newspaper, a regional farm newspaper, several city newspapers, and several national magazines. Again, he used a club offer to subscribe to the last four publications. ${ }^{76}$

But 1900 proved to be a hard year for the family. In June, he had a bad accident in the field: "in unhitching my team the tug caught in the plow tongue, frightened my team causing them to run away dragging me some distance running over me twice with the plow, breaking my leg and bruising me considerably." It was a painful, compound fracture, and he was not able to leave home for over two months. Eleven months later, he was still walking with canes. While Sanborn was recovering, on September 13, his son 
Willie became sick. Diarrhea, fever, and "a weak heart" led to the boy's death five days later. ${ }^{77}$

In the midst of these trials, Sanborn turned to reading. Several weeks after his accident, his mother and sister arrived to help nurse him. They brought with them the Mound City District School Library, "a new one just bought -it will be a windfall for me" he wrote in his diary. It is unclear how many books there were, but Sanborn was happy to have something additional to read. Several weeks later he listed in his diary nine books that he read while he was "laid up." 78 All of them were novels; six were historical fiction. Several are about American history, including Janice Meredith: A Story of the American Revolution and Red Rock: A Chronicle of Reconstruction. Richard Carvel was written by a young Winston Churchill and tells the story of a Maryland family during the American Revolution. The Prince of India is by Lew Wallace (of Ben-Hur fame) and is subtitled Or, Why Constantinople Fell. When Knighthood was in Flower is about Tudor England, and To Have and To Hold is a romance set in Colonial Virginia. The other three books were contemporary fiction. Like Lucy White, John Sanborn enjoyed both historical fiction and popular novels. ${ }^{79}$

Sanborn also used reading materials to deal with the death of his son. At the end of the 1900 diary, Sanborn wrote: "He lived unknown and few could know / When Willie ceased to be, / But he is in his grave, and, oh, / The difference to me." How did Sanborn learn these lines from William Wordsworth's poem "She Dwelt Among The Untrodden Ways?" 80 Did he learn it in common school during the mid-nineteenth century? Was it printed in one of the magazines Sanborn read? Whatever the case, Sanborn applied lines from a one hundred-year-old love poem to his own situation, thoughtfully using literature to help deal with his loss.

Sanborn also placed a sheet of paper in the back of the 1900 diary. It contains three handwritten extracts from a short story printed in the Atlantic Monthly in January of 1900. Titled "Mother," the short story tells the story of a young woman who falls in love, marries, gives birth to a baby boy, and then loses the child to Meningitis. She returns home to discover that there is healing in sharing her wounds with her mother, who also lost a son. The third extract is from the last paragraph of the piece: "Somewhere in a light as pure as that my little laddie is happy. God may have him to take care of for a time, but he will always be my child." 81 Sanborn does not record a subscription to the Atlantic Monthly in his diary. Perhaps his own mother sent him the short story; she was visiting when his son died. Again, Sanborn transformed the content of the selection-the story is about a woman grieving for her son-into a way of coping with his own loss. 
The next seven years of the family's life were marked by a number of moves. In 1902 he sold the farm in Missouri and moved eighty miles southwest to a farm in Nemaha County, Kansas, near the town of Corning. The next year he sold the Kansas farm and moved back to Macon County in north-central Missouri. Two years later he sold his 120-acre farm to buy a 240-acre farm ten miles north. It appears that Sanborn was constantly looking for ways to increase his land holdings and his net worth. He inventoried his property at the back of several diaries, and the total value did increase from year to year. In 1907, he sold his farm and moved to California. The last diary ends with John, Emma, and Ethel (Edith was attending the University of Missouri) in California, living with John's brother in Yuba City and looking for a farm to purchase. Did they finally settle down, or did he move them yet again? Unfortunately, these questions remain unanswered.

During the rest of his years in the Midwest, however, Sanborn continued to subscribe to local newspapers, farm papers, city newspapers, and magazines. No matter where the family lived, the house was sure to be full of reading matter. In 1902 it was the Mound City News, the Kansas City Journal, Woman's Home Companion, Harper's Weekly, Public Opinion, and Everybody's Magazine. When the family moved to Kansas, Sanborn quickly subscribed for the Corning Gazette, and when they returned to Missouri, he purchased a subscription to the Macon Republican. In 1906 he subscribed to the Iowa Homestead, using its clubbing offers to get the Chicago Inter Ocean, the Farm Gazette, the Homemaker, and the Kansas City Star. He also subscribed for the Polo Visitor, the local newspaper from Polo, Illinois, where his mother lived and where he probably was born. In different years he subscribed to other popular magazines such as the World's Work, the Review of Reviews, and Cosmopolitan Magazine. Sanborn did not subscribe to many popular magazines for more than one year at a time. It appears that he used dual-subscription clubs to shop for the best prices. ${ }^{82}$

It appears that Sanborn used print materials in the three ways discussed. His consistent subscription to local newspapers suggests that he was interested in the news of the communities where he lived, even if he was not very attached to those communities themselves. He subscribed to a variety of national magazines, most of which were probably read for pleasure by him or by the women in his family. Perhaps one member of the family read them aloud. Sanborn's subscription to farm newspapers suggests that he was interested in the useful information they could provide.

Sanborn was a late-nineteenth century Midwestern farmer who frequently moved in order to better his lot financially. His diaries detail these 
moves, the value of his property, the crops he grew, and his daily activities. In the midst of crises in his life, however, his diaries reveal specific ways that Sanborn used books and periodicals to deal with his situation. He read novels for pleasure and to get his mind off of the pain involved with his healing leg. He also used literature-both poetry and popular magazine fiction-to help him deal with the pain of losing his only son.

This chapter has presented a description of the reading habits of country people in the lower Midwest, drawn from their own writings. The rural Midwesterners used as examples illustrate patterns that emerge from a quantitative and qualitative study of their records. Country people have always been an incredibly diverse lot. It is not surprising that their reading habits were unique and varied. However, it is clear that Asa Markel was right: country people read many of the same publications as city people in the late nineteenth and early twentieth centuries: local newspapers, novels, magazines, and city newspapers. Rural readers also read these materials for many of the same reasons as city readers: community building, entertainment, and useful information. These observations provide the backdrop for the examination of the characteristics of those that read farm newspapers presented in the next chapter. 
Page Intentionally Left Blank 


\section{Chapter Four \\ "Who Read the Agricultural \\ Journals?":"

\author{
Farm Newspaper Subscribers in the \\ Lower Midwest
}

I have fulfilled my contract, as far as I was permitted to do it. I said I could make your paper of interest to all classes, and I have. I said I could run your circulation up to twenty thousand copies, and if I had had two more weeks I'd have done it. And I'd have given you the best class of readers that ever an agricultural paper had-not a farmer in it, nor a solitary individual who could tell a watermelon from a peach-vine to save his life. You are the loser by this rupture, not me....

- Mark Twain, "How I Edited an Agricultural Paper Once"2

Mark Twain's treatment of farm newspapers did not only lampoon their editors. In the final paragraph of the essay, Twain also poked fun at their readers. He had been severely rebuked by the farm newspaper's regular editor for knowing nothing about farming and thereby making the paper ridiculous in the eyes of its rural audience. Twain responded that his issue had greatly increased the paper's circulation, and it had increased it among non-country people. Since townspeople and city people knew nothing about farming, they eagerly bought a paper that made sensational claims and gave confident advice, whether the advice was good or not. It is not clear what Twain meant by "a better class of readers." Was he calling country people inferior to townspeople? Or was he jesting that gullible readers in towns and cities were more desirable because they would buy the product he had produced? In either case, Twain recognized that the readers of one's farm newspaper were as important a consideration as the editor and the content. 
Historians of the farm press have presented a variety of opinions on who subscribed to and read farm newspapers. ${ }^{3}$ But when describing the readership of farm newspapers, many scholars have relied heavily on evidence internal to the papers themselves. Evidence gathered from sources outside of the papers would greatly assist in assessing these competing claims. Two scholarly works have supplied some empirical data on readership.

In 1920, Ralph Nafziger, then an undergraduate student in the school of agriculture at the University of Wisconsin, surveyed farmers as part of his undergraduate thesis project. He sent a questionnaire to one hundred "representative, progressive" farmers in that state. The names were taken from the membership of the Wisconsin Livestock Breeders' Association and the Wisconsin Agricultural Experiment Association. Fifty-one farmers responded. The previous chapter noted that most of Nafziger's respondents subscribed to multiple farm newspapers. These farmers mainly subscribed to regional newspapers such as the Wisconsin Agriculturist and Hoard's Dairyman. Some received Wallaces' Farmer and the Iowa Homestead. Nafziger also recorded descriptive comments from respondents about what they desired in a farm newspaper. Unfortunately, while this survey tells us about the things readers expected from their farm paper, it reveals little about the characteristics of those readers themselves. ${ }^{4}$

More useful for our purposes is a 1989 article by Sally McMurry, who examined the subscription list of Henry Balcom, an agent for the Albany Cultivator, from 1839 to 1860 . She searched for the list's 132 names in local newspapers, county histories, county atlases, and the federal manuscript census. She came to several conclusions about readers of farm newspapers in the mid-nineteenth century. More than two thirds of the subscribers on the list were farmers; the other third were professionals and others from towns that relied on farmers for their livelihood. In addition, although most of the farmers on the list had incomes above the county average, they were not rich. She describes most of these farmers were conservative innovators, not wild-eyed experimenters. ${ }^{5}$

This chapter will add empirical data to the consideration of the characteristics of regional farm newspapers' readers in several ways. First, it will consider several contemporary statistical sources that address the reading of farm newspapers. During the 1910s and 1920s, researchers at the United States Department of Agriculture and the Iowa State Agricultural Experiment Station, as well as independent rural sociologists, conducted indepth surveys of rural Midwesterners. The published reports of these surveys contain some information on the reading habits of country people and draw a preliminary sketch of the recipients and readers of farm newspapers. ${ }^{6}$ 
I will then examine a subscription list for a lower Midwestern regional farm newspaper. William H. Mills was a club-raiser for Wallaces' Farmer in Story County, Iowa, during the 1920s. His club lists include 194 different individuals whom he signed up to receive the paper. Like McMurry, I have located as many of these individuals as possible in the federal and state manuscript censuses, county directories, county atlases, and plat maps. Their characteristics provide another look at the characteristics of readers of farm newspapers in the early twentieth century. ${ }^{7}$

Finally, the chapter will present case studies from the record groups examined. Forty-five of the individuals and groups in my database of rural readers read farm newspapers. This is almost half of those for which there is evidence of specific reading. Furthermore, twenty-five individuals and one group left evidence of subscribing to or reading at least one of the four regional farm newspapers examined: the Iowa Homestead, the Missouri Ruralist, the Prairie Farmer, and Wallaces' Farmer. I have researched these country people in the same types of sources as the individuals in the subscription list. Their stories provide detailed snapshots of individual readers of farm newspapers during the period. There are shortcomings to this type of research. Federal census data are far from complete, and county histories often include only the most wealthy and prominent farmers. For these reasons, my analysis cannot be seen as a statistical survey; it should be regarded more as a group biography. Still, these snapshots are of actual farmers and their families that we know received a farm newspaper. They help to put a human face on those who read farm newspapers in the lower Midwest at the turn of the twentieth century. ${ }^{8}$

The editors and publishers of Midwestern farm newspapers targeted as wide an audience as possible and claimed that farmers of all types read their publications. It appears from my research that their claims were correct. Landowners, renters, and farm laborers of widely varying situations and incomes subscribed to Midwestern farm papers.

\section{SURVEYS OF RURAL READERS}

In the early 1910s, the United States Department of Agriculture's Bureau of Plant Industry commissioned a study of farmers' use of information sources. Four extension agents walked four routes through rural parts of the country, stopping at every farmhouse to inquire about the family's use of various ways to get information about farming. Two of the routes included states in the Lower Midwest: the North Central route started in northwestern Ohio and proceeded through northern Indiana, northern Illinois, and southeastern Iowa. The West Central route proceeded across northern Missouri and 
Table 9. 1913 U. S. D. A. Survey-Farmers Taking Agricultural Papers

\begin{tabular}{llll}
\hline Section & Farmers & \multicolumn{2}{c}{ Taking Farm Papers } \\
(States Visited) & Visited & Number & $\%$ \\
\hline North Atlantic States (NY, PA, MD) & 1,285 & 893 & 69.5 \\
Southern States (GA, AL, MS) & 1,001 & 454 & 45.4 \\
North-Central States (OH, IN, IL, IA) & 707 & 534 & 75.5 \\
West-Central States (MO, KS) & 705 & 542 & 76.9 \\
Total or average & 3,698 & 2,423 & 65.5 \\
\hline
\end{tabular}

Source: U. S. Department of Agriculture, Bureau of Plant Industry, "The Relation of Agricultural Extension Agencies to Farm Practices," by C. Beaman Smith and H. K. Atwood, in Miscellaneous Papers, Bureau of Plant Industry Circular No. 117 (Washington, D. C.: Government Printing Office, 1913), 18.

northern Kansas. ${ }^{9}$ The agents asked each farm family if they received government agricultural bulletins, attended farmers' institutes, subscribed to agricultural papers, talked to demonstration agents, owned agricultural books, or belonged to an agricultural society. C. Beaman Smith and H. K. Atwood published the results in 1913. Table 9 gives the numbers of farmers they surveyed who received farm newspapers. Overall, sixty five percent of the farmers visited received at least one farm newspaper. Among farmers along the North and West Central routes, the proportion was over seventy five percent. None of the other educational agencies was utilized by more than half of the respondents. About forty percent of those surveyed received agricultural bulletins, thirty percent attended farmer's institutes, fifteen percent belonged to agricultural societies, and 3 percent had talked to an agricultural demonstration agent. ${ }^{10}$

Furthermore, those interviewed named farm newspapers as the most influential information source. Country people were asked which source of information was most helpful for their farming operation. Forty percent said farm newspapers, more than twice as many as said all of the other sources put together. Table 10 reproduces the results for this question. Interestingly, a slightly larger proportion (almost forty-four percent) told the agents that none of the sources of information was helpful. Unfortunately, the agents failed to ask if and to what extent the farmers had put into practice suggestions from farm newspapers, questions they did ask about several of the other sources of agricultural information. Also, the survey tells us nothing about the characteristics of the farmers who actually received or read the farm newspapers. Still, it does provide direct evidence that a large number of farmers received farm newspapers and found them useful. 


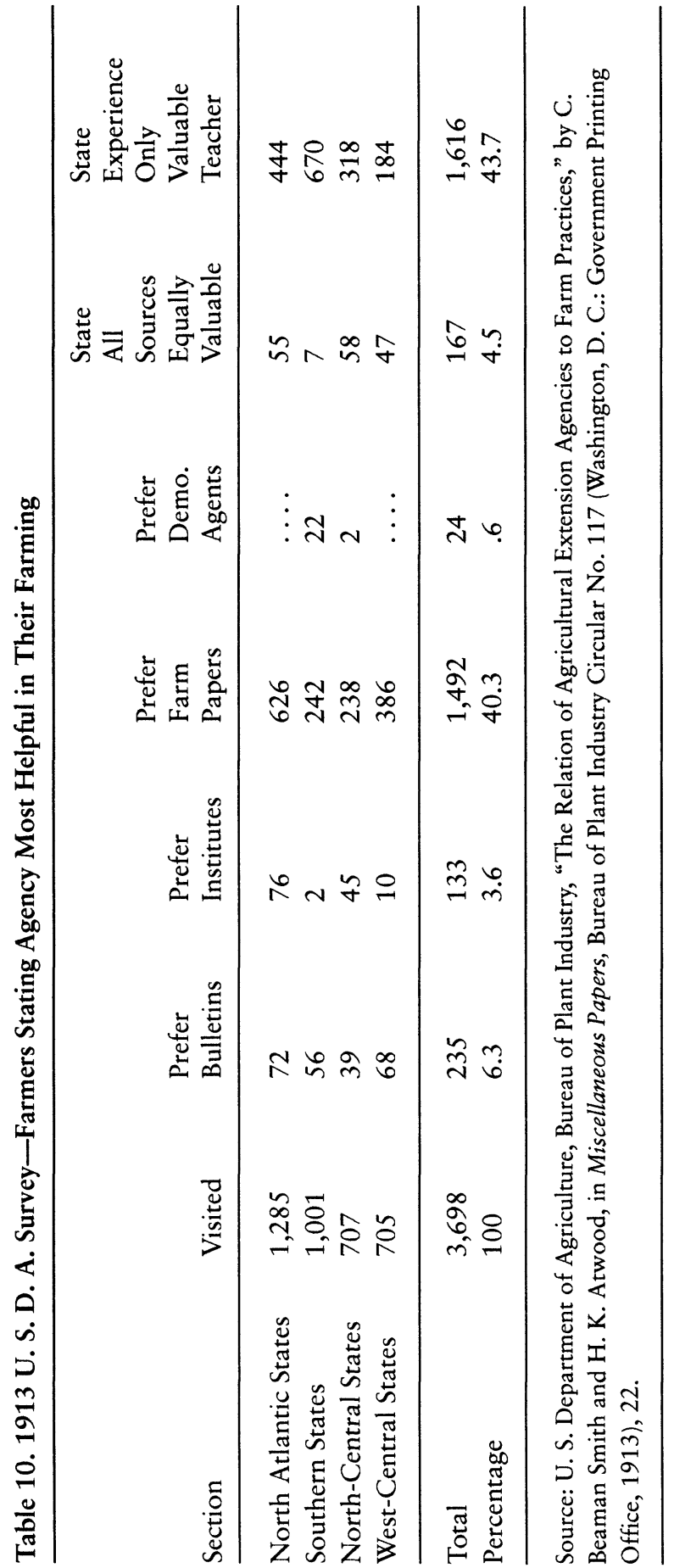


Several years later Paul S. Peirce, a researcher at the State University of Iowa, published results of sociological surveys in three rural townships in southern and eastern Iowa. Three graduate students interviewed members of the communities in which they had grown up, and Peirce compiled the answers. Unfortunately, the townships were not identified, "in order that the publication of uncomplimentary facts might not be construed as a singling out of a given community for invidious or discriminatory publicity." 11 The 1910 s and 1920 s saw the beginning of rural sociology, as researchers published surveys of other rural districts across the country. Like these other studies, this survey described the geographical, demographic, economic, educational, religious, and social characteristics of these communities. ${ }^{12}$

As part of the report's assessment of the educational makeup of the community, questions were asked about residents' receipt of newspapers and magazines. The results for farm newspapers are reproduced in Table 11. High percentages of both owners (between sixty-two and ninety seven percent) and tenants (between sixty-four and eighty-seven percent) received farm newspapers. In two townships more owners received farm papers than tenants, but in the third slightly more tenants received them than owners. Also in two of the three townships, about forty percent of the farm laborers and hired hands surveyed received farm newspapers. This goes beyond that of Smith and Atwood to give figures for different sub-groups of country people. It suggests that the claims made by farm newspapers were generally accurate: all types of country people, including farm owners, tenants, and hired hands received their products.

Over the next ten years, the rural Sociology Section of the Iowa State Agricultural Experiment Station published many similar surveys. These surveys covered Clay and Sac Counties in northwestern Iowa, Boone

Table 11. 1917 University of Iowa Survey-Residents Receiving Farm Newspapers

\begin{tabular}{lllllllll}
\hline & \multicolumn{2}{c}{ Owners } & \multicolumn{2}{c}{ Tenants } & \multicolumn{2}{c}{ Laborers } & \multicolumn{2}{c}{ Total } \\
& No. & $\%$ & No. & $\%$ & No. & $\%$ & No. & $\%$ \\
\hline Township C & 123 & 97 & 41 & 87 & 0 & 0 & 164 & 89 \\
Township L & 41 & 62 & 38 & 64 & 4 & 37 & 93 & 61 \\
Township M & 99 & 82 & 21 & 75 & 8 & 43 & 129 & 77 \\
\hline
\end{tabular}

Source: Paul S. Peirce, "Social Surveys of Three Rural Townships in Iowa," University of Iowa Monographs-Studies in the Social Sciences 5(2)(1917): 66-67. 
counties in Eastern Iowa. The Bulletin of the Experiment Station published their results. These surveys presented similar findings about the reading of and Story Counties in central Iowa, and Black Hawk, Buchanan, and Cedar farm newspapers among country people. In all of them, farm newspapers were the most common agricultural publication received. In each, at least half of those surveyed received farm newspapers. Both landowners and renters received the publications, the former receiving them in somewhat larger numbers than the latter. There are few changes in the figures for reading from the late 1910 s to the middle of the 1920s. Changes in the rural economy seem not to have greatly affected rural Midwesterners' reception of farm newspapers. ${ }^{13}$

Similar statistics are given for the state of Missouri in the late 1910s and early 1920s. Carl C. Taylor, a prominent early Rural Sociologist, did surveys of 306 "Central Missouri Farmers" and 429 farm families in "a Southeast Missouri Community" and reported the results in his 1926 textbook Rural Sociology: A Study of Rural Problems. His results mirror those of the Iowa surveys. Missouri farmers received farm newspapers more than other agricultural publications, and over half of those surveyed received a farm paper. Taylor's survey in southeast Missouri also found that almost a third of sharecroppers and hired men read farm newspapers. These results for farm newspapers are reported in Table $12 .{ }^{14}$

All of these surveys provide evidence that by the second decade of the twentieth century, farm newspapers were received in all types of Midwestern farm households. As one synthesis of reading research summarized in 1930, "the data presented show that tenants do not read as much as farm owners. [However] the difference between these two types of farmers is far more marked in such states as Tennessee and North Carolina than in the prairie states." 15 In the Midwest, both owners and tenants received farm newspapers.

Table 12. Carl C. Taylor Survey of a Southeast Missouri CommunityRespondents Receiving Farm Newspapers

\begin{tabular}{|c|c|c|c|c|c|c|c|c|c|}
\hline \multicolumn{2}{|c|}{41 Owners } & \multicolumn{2}{|c|}{180 Tenants } & \multicolumn{2}{|c|}{29 Croppers } & \multicolumn{2}{|c|}{179 Hired Men } & \multicolumn{2}{|c|}{429 Total } \\
\hline No. & $\%$ & No. & $\%$ & No. & $\%$ & No. & $\%$ & No & $\%$ \\
\hline 36 & 80 & 125 & 70 & 10 & 35 & 52 & 29 & 223 & 52.0 \\
\hline
\end{tabular}

Source: Carl C. Taylor, Rural Sociology: A Study of Rural Problems (New York: Harper and Brothers, 1926), 268-271. 


\section{ONE FARM NEWSPAPER'S SUBSCRIPTION LIST}

The statistical data presented above suggest that all types of farmers received farm newspapers. Another way to obtain information about the characteristics of readers of farm papers is to examine a subscription or club list. Newspaper or magazine clubs were a common way for publishers to increase their circulation. As described in chapter one, a club-raiser collected payments from relatives or neighbors who wanted to receive a publication. Many publishers offered free subscriptions, discounts, premiums, or cash to the club-raiser for his or her work advertising the paper and collecting payments. Lucy Van Voorhis White, described in chapter three, mentioned in 1908 that she was collecting names for the Mother's Magazine. ${ }^{16}$

William Henry Mills collected names and subscription payments for Wallaces' Farmer between 1925 and 1930. Mills was born in Ohio in 1864 to parents who were Irish immigrants. His education was complete after ten years of common school. He moved to Story County, Iowa in 1885 and married six years later. Ada Mills gave birth to three children: Harry in 1892, Sadie in 1895 , and Mary in 1898. By the early twentieth century, Mills owned 100 acres of land in the corner of Grant Township, about two miles east of the town of Ames, and he may have also rented land elsewhere. In 1915 his farm was worth eighteen thousand dollars, and his livestock was worth eleven hundred dollars: five horses, six milk cows, six calves, and three hundred "fowls of all kinds." His income for 1914 was fifteen hundred dollars. His 1917 gross income (probably inflated by wartime demand) was over thirty-six hundred dollars. ${ }^{17}$

Mills became a club-raiser for Wallaces' Farmer in 1925. He got his neighbors and acquaintances to subscribe to the paper, collected their money, and sent it in. In return, the paper gave him a free subscription and a number of premiums, including some cash. He was also entered into annual club-raising contests that paid cash prizes. For instance, in 1928 he received a letter from the newspaper notifying him that his "splendid club of 82 names" was the eighth largest in their contest. As a result, he had won a prize of fifteen dollars in addition to his monthly salary bonus of twelve dollars. ${ }^{18}$ Mills sent new names to the publisher on special forms, along with payment. At the end of each year, the publisher sent Mills a list of those whose subscriptions would expire shortly. Mills saved these lists. When the lists are all put together, they provide the names of 194 different subscribers. I compared this list to the 1915 and 1925 Iowa Manuscript Censuses, the 1920 Federal Manuscript Census, a Story County atlas, and one Story County directory. Since Story County was the home of the Iowa State College of Agriculture and Mechanic Arts (now Iowa State University), I also consulted one directory and several yearbooks from the college. ${ }^{19} \mathrm{My}$ 
research uncovered information about ninety-eight of the 194 subscribers. Mills was not actively soliciting subscriptions during the period covered by this project, but the social surveys examined above suggest that subscription behavior did not change dramatically during the 1920s. Therefore, I believe they provide a reliable picture of the readership of Wallaces' Farmer at the end of the period under study: for instance in 1920.

Of the 194 subscribers on Mills' lists, two of them were companies: O'Neil Dairy, located in Ames, and Robb Brothers, a company that did not appear in the sources consulted. In addition, ten of the names were identifiable as women (five percent). Since only initials are given for more than half of the subscribers (116 of the 192 names), it was difficult to determine their gender. But seven names had Mrs. before them, and three had obviously female first names. Unfortunately, I could find none of them in the sources consulted. Even so, the ten identified women represent a significantly larger proportion than Sally McMurry found in her survey of a mid-nineteenth century subscription list. She only found one woman out of 132 names. Furthermore, since women in farm families often read materials subscribedfor by their husbands or fathers, as noted in the previous chapter, one should not assume that only five percent of women read Wallaces' Farmer. ${ }^{20}$

Table 13. The Subscription List of William H. Mills-Occupations

\begin{tabular}{lc}
\hline Occupation & Number of Subscribers \\
\hline Farmer & 61 \\
Professor at Iowa State Agricultural College & 16 \\
Student at Iowa State Agricultural College & 4 \\
Carpenter & 3 \\
Farm Hand & 2 \\
Bricklayer & 1 \\
Concrete Finisher & 1 \\
Drayman & 1 \\
Government Employee & 1 \\
Harness Dealer & 1 \\
Insurance Agent & 1 \\
Laborer & 1 \\
Physician & 1 \\
Steam Fitter & 1 \\
Teamster & 1 \\
Traveling Salesman & 1 \\
Truck Driver & 1 \\
\hline
\end{tabular}

Source: 1915 Iowa Manuscript Census, 1920 Federal Manuscript Census, 1925 Iowa Manuscript Census. 
Table 14. The Subscription List of William H. Mills-Economic Status of FarmOwners

\begin{tabular}{|c|c|c|c|c|}
\hline Farmer & Mortgage & $\begin{array}{l}\text { Value } \\
\text { of Farm }\end{array}$ & $\begin{array}{l}\text { Value of } \\
\text { farm minus } \\
\text { mortgage }\end{array}$ & $\begin{array}{l}\text { Value } \\
\text { of livesock }\end{array}$ \\
\hline Gossett, W. L. & $\mathrm{n} / \mathrm{a}$ & $\$ 51,000$ & $\$ 51,000$ & $\$ 3,867$ \\
\hline Davis, C. F. & $\$ 6,000$ & $\$ 56,000$ & $\$ 50,000$ & $\$ 3,161$ \\
\hline Kingsbury, S. N. & $\$ 800$ & $\$ 36,000$ & $\$ 35,200$ & $\$ 5,140$ \\
\hline Maxwell, Harry D. & $\mathrm{n} / \mathrm{a}$ & $\$ 30,000$ & $\$ 30,000$ & $\$ 3,755$ \\
\hline Taylor, William* & $\mathrm{n} / \mathrm{a}$ & $\$ 30,000$ & $\$ 30,000$ & $\$ 1,530$ \\
\hline Eddy, F. S. & $\$ 5,000$ & $\$ 33,200$ & $\$ 28,200$ & $\$ 1,895$ \\
\hline Kyle, John Thomas & $\$ 5,000$ & $\$ 30,000$ & $\$ 25,000$ & $\$ 2,790$ \\
\hline Johnson, Charles & $\mathrm{n} / \mathrm{a}$ & $\$ 22,000$ & $\$ 22,000$ & $\$ 1,368$ \\
\hline Jensen, C. F. & $\$ 3,500$ & $\$ 24,000$ & $\$ 20,500$ & $\$ 3,332$ \\
\hline Templeton, W. F. & $\mathrm{n} / \mathrm{a}$ & $\$ 20,000$ & $\$ 20,000$ & $\$ 1,930$ \\
\hline Wakefield, Sam & $\mathrm{n} / \mathrm{a}$ & $\$ 20,000$ & $\$ 20,000$ & $\$ 1,820$ \\
\hline Warren, John F. & $\$ 27,000$ & $\$ 46,800$ & $\$ 19,800$ & $\$ 7,090$ \\
\hline Howland, Balus & $\$ 1,000$ & $\$ 19,680$ & $\$ 18,680$ & $\$ 1,321$ \\
\hline Mills, William H. & $\mathrm{n} / \mathrm{a}$ & $\$ 18,000$ & $\$ 18,000$ & $\$ 1,135$ \\
\hline Hostetter, George & $\$ 3,200$ & $\$ 20,710$ & $\$ 17,510$ & $\$ 1,389$ \\
\hline Halstead, C. W. & $\$ 18,000$ & $\$ 35,000$ & $\$ 17,000$ & $\$ 4,500$ \\
\hline Hilgendorf, W. H. & $\mathrm{n} / \mathrm{a}$ & $\$ 16,000$ & $\$ 16,000$ & $\$ 1,915$ \\
\hline Kelley, Albert & $\mathrm{n} / \mathrm{a}$ & $\$ 16,000$ & $\$ 16,000$ & $\$ 1,510$ \\
\hline Allen, Jay H. & $\$ 1,500$ & $\$ 16,000$ & $\$ 14,500$ & $\$ 6,525$ \\
\hline Kingsbury, Ernest & $\$ 3,000$ & $\$ 16,000$ & $\$ 13,000$ & $\$ 2,770$ \\
\hline Kulow, G. A. & $\$ 5,500$ & $\$ 18,000$ & $\$ 12,500$ & $\$ 4,985$ \\
\hline Hunter, Ernest J. & $\mathrm{n} / \mathrm{a}$ & $\$ 11,800$ & $\$ 11,800$ & $\$ 1,479$ \\
\hline Skiles, Fred & $\mathrm{n} / \mathrm{a}$ & $\$ 11,800$ & $\$ 11,800$ & $\$ 1,092$ \\
\hline Osborn, T. C. & $\mathrm{n} / \mathrm{a}$ & $\$ 11,000$ & $\$ 11,000$ & $\$ 945$ \\
\hline Graves, Ned T. & $\mathrm{n} / \mathrm{a}$ & $\$ 8,000$ & $\$ 8,000$ & $\$ 486$ \\
\hline Hankins, Sylvester & $\$ 8,000$ & $\$ 15,200$ & $\$ 7,200$ & $\mathrm{n} / \mathrm{a}$ \\
\hline Kooser, John B. & $\$ 1,400$ & $\$ 7,000$ & $\$ 5,600$ & $\mathrm{n} / \mathrm{a}$ \\
\hline Arrasmith, Aden & $\$ 7,000$ & $\$ 12,000$ & $\$ 5,000$ & $\$ 188$ \\
\hline Weston, C. E. & $\$ 2,400$ & $\$ 6,000$ & $\$ 3,600$ & $\mathrm{n} / \mathrm{a}$ \\
\hline Smith, Charles S. & $\mathrm{n} / \mathrm{a}$ & $\$ 1,600$ & $\$ 1,600$ & $\mathrm{n} / \mathrm{a}$ \\
\hline Huntley, J. E. & $\$ 2,100$ & $\$ 2,800$ & $\$ 700$ & $\mathrm{n} / \mathrm{a}$ \\
\hline Armstrong, Leo & $\mathrm{n} / \mathrm{a}$ & $\mathrm{n} / \mathrm{a}$ & $\mathrm{n} / \mathrm{a}$ & $\mathrm{n} / \mathrm{a}$ \\
\hline
\end{tabular}

n/a Not available

*This William Taylor lived in Grant township and should not be confused with a William Taylor from Milford township who was a renter. 
Of the ninety-eight subscribers found, sixty-one were farmers, or sixtytwo percent. This proportion matches closely the figure that Sally McMurry found for farmers in the mid-nineteenth century. She found that 87 of 132 subscribers were farmers, or sixty-six percent. The occupations of the other subscribers identified are given in Table 13. Twenty of them wereassociated with the Iowa State College: sixteen were professors and four were students. Other subscribers were professionals or other workers in the town of Ames itself. This list suggests a conclusion that parallels McMurry's: those who received Wallaces' Farmer as part of Mills's club were "overwhelmingly farmers and only secondarily local tradesmen and professionals." 21 The sixty-one identified farmers were divided almost evenly between owners and renters; there were thirty-two of the former and twenty-nine of the latter. According to the estimates made for the census, owners' farms had widely varying values, as shown in Table 14 . The United States census gives $\$ 41,414.61$ as the average farm value for Story County in 1920 , but this value is probably inflated by wartime land prices. Likewise, the 1930 Census figure- $\$ 26,826.27$ - may be low due to the Great Depression. ${ }^{22}$ Still, the farmers on the list may be separated into several economic groups. Among those who owned land, there are two whose farms were worth well above the rest: W. L. Gossett and C. F. Davis both owned property valued over fifty thousand dollars. This would be about half a million dollars in 2003. Then, there were a handful of farmers whose farm value was over thirty thousand dollars. These might be called wealthy owners. A larger group of individual farms were each worth between ten thousand and thirty thousand dollars (between $\$ 100,000$ and $\$ 300,000$ in 2003), which might be called average. Those with farm values below ten thousand dollars were marginal landowners: some of their farms were significantly mortgaged.

Table 15. The Subscription List of William H. Mills-Economic Status of Renters

\begin{tabular}{lc}
\hline Farmer & Value of livestock \\
\hline Lee, Jacob & $\$ 3,045$ \\
Banks, Glenn T. & $\$ 2,835$ \\
Warren, William & $\$ 2,734$ \\
Jensen, Chris & $\$ 2,645$ \\
Taylor, William & \\
Lawson, Richard & $\$ 2,480$ \\
VanPatter, Charles & $\$ 2,105$ \\
McGrath, E. W. & $\$ 1,790$ \\
Templeton, Milton E. & $\$ 1,788$ \\
Canady, Charles E. & $\$ 1,775$ \\
& $\$ 1,755$
\end{tabular}


Table 15. The Subscription List of William H. Mills-Economic Status of Renters (continued)

\begin{tabular}{lc}
\hline Farmer & Value of livestock \\
\hline Sanders, Eden & $\$ 1,752$ \\
Andrew, F. E. & $\$ 1,505$ \\
Brokaw, Frank & $\$ 1,360$ \\
Hallowell, Charles & $\$ 1,198$ \\
Moses, Scott W. & $\$ 1,120$ \\
Scott, John M. & $\$ 951$ \\
Markley, R. W. & $\$ 738$ \\
Vanpatter, Ben & $\$ 600$ \\
Auld, Charles & $\mathrm{n} / \mathrm{a}$ \\
Banks, Alvin & $\mathrm{n} / \mathrm{a}$ \\
Banks, George W. & $\mathrm{n} / \mathrm{a}$ \\
Davis, Fred E. & $\mathrm{n} / \mathrm{a}$ \\
Campbell, Robert & $\mathrm{n} / \mathrm{a}$ \\
Childs, Frank L. & $\mathrm{n} / \mathrm{a}$ \\
Latham, G. W. & $\mathrm{n} / \mathrm{a}$ \\
Lowe, James & $\mathrm{n} / \mathrm{a}$ \\
Osborn, G. L. & $\mathrm{n} / \mathrm{a}$ \\
Shearer, Frank L. & $\mathrm{n} / \mathrm{a}$ \\
Swanson, Adolph & $\mathrm{n} / \mathrm{a}$ \\
\hline
\end{tabular}

n/a Not available

*This William Taylor lived in Milford township and should not be confused with a William Taylor from Grant township who was a landowner.

Source: 1915 Iowa Manuscript Census, 1925 Iowa Manuscript Census

Renters cannot be classified by farm value, but their income and the value of the livestock they owned are suggestive. These figures are given in Table 15. If one compares these figures with those in Table 14, one finds that some renters actually owned more livestock than many landowners. Apparently they had some money to invest, but either there was not land available for them to buy or it was priced beyond what they could afford. These well-off renters would have lived a significantly different life than the renters at the bottom of the list whose livestock holdings can be described as marginal at best. $^{23}$

The wide diversity in economic status is somewhat different than McMurry's findings for the mid-nineteenth century. She found that twothirds of those who received the farm paper "owned farms that were larger and of greater value than the county average." While there were only a 
handful of very wealthy farmers in her sample, a significant majority of those who received the paper were well-off. ${ }^{24}$ Mills's list shows a much larger number of farmers at the bottom of the scale. Indeed, from this list, it appears that more farmers in the lower half of the economic scale received the paper than those above.

The ethnic background of the farmers was mixed. One rough way to assess the ethnicity of farmers is to use the "Place of Birth" information provided by many censuses. Table 16 gives the place of birth of each individual and of their parents. More than half of the farmers were born in Iowa. Most of the rest were born in the Midwest, broadly construed. However two were born in Pennsylvania, and five were born outside the country. The diversity in ethnic background is more evident from the birthplaces of the farmers' parents.

Table 16. The Subscription List of William H. Mills-Place of Origin

\begin{tabular}{|c|c|c|c|}
\hline Farmer & Individual Born & Father Born & Mother Born \\
\hline Allen, Jay H. & Pennsylvania & Pennsylvania & Pennsylvania \\
\hline Andrew, F. E & Illinois & New York & Illinois \\
\hline Armstrong, Leo & Iowa & New York & Iowa \\
\hline Arrasmith, Aden & Iowa & Kentucky & Ohio \\
\hline Auld, Charles & Iowa & Illinois & Indiana \\
\hline Banks, Alvin & Iowa & Canada & Iowa \\
\hline Banks, George W. & Iowa & Canada & Illinois \\
\hline Banks, Glenn T. & Iowa & New York & New York \\
\hline Brokaw, Frank & Illinois & New York & New York \\
\hline Campbell, Robert & Iowa & Iowa & Iowa \\
\hline Canady, Charles E. & Iowa & Kentucky & Illinois \\
\hline Childs, Frank L. & Iowa & New Hampshire & New York \\
\hline Davis, C. F. & Michigan & New York & New York \\
\hline Davis, Fred E. & Iowa & Michigan & New York \\
\hline Eddy, F. S. & Illinois & Ohio & Illinois \\
\hline Gossett, W. L. & Illinois & Ohio & Virginia \\
\hline Graves, Ned T. & Iowa & Iowa & Iowa \\
\hline Hallowell, Charles & Illinois & Canada & Ireland \\
\hline Halstead, C. W. & Illinois & Sweden & Sweden \\
\hline Hankins, Sylvester & Iowa & Illinois & Iowa \\
\hline Hilgendorf, W. H. & Wisconsin & Germany & Germany \\
\hline Hostetter, George & Illinois & Ohio & Illinois \\
\hline Howland, Balus & $\mathrm{n} / \mathrm{a}$ & $\mathrm{n} / \mathrm{a}$ & $\mathrm{n} / \mathrm{a}$ \\
\hline Hunter, Ernest J. & Iowa & Pennsylvania & Ohio \\
\hline Huntley, J. E. & Iowa & Illinois & Illinois \\
\hline Jensen, C. F. & Denmark & Denmark & Denmark \\
\hline Jensen, Chris & Denmark & Denmark & Denmark \\
\hline
\end{tabular}


Table 16. The Subscription List of William H. Mills-Place of Origin (continued)

\begin{tabular}{|c|c|c|c|}
\hline Farmer & Individual Born & Father Born & Mother Born \\
\hline Johnson, Chas. & Sweden & Sweden & Sweden \\
\hline Kelley, Albert & Iowa & Indiana & Michigan \\
\hline Kingsbury, Ernest & Iowa & Canada & Canada \\
\hline Kingsbury, S. N. & Illinois & Canada & Vermont \\
\hline Kooser, John B. & Iowa & Pennsylvania & Pennsylvania \\
\hline Kulow, G. A. & Iowa & Germany & Ohio \\
\hline Kyle, John Thomas & Iowa & Ireland & Scotland \\
\hline Latham, G. W. & Iowa & Indiana & Missouri \\
\hline Lawson, Richard & Kansas & Norway & Iowa \\
\hline Lee, Jacob & Norway & Norway & Norway \\
\hline Lowe, James & Iowa & Pennsylvania & Iowa \\
\hline Markley, R. W. & Indiana & Indiana & Indiana \\
\hline Maxwell, Harry D. & Iowa & New York & New York \\
\hline McGrath, E. W. & Iowa & Illinois & Iowa \\
\hline Mills, William Henry & Ohio & Ireland & Ireland \\
\hline Moses, Scott W. & Iowa & Pennsylvania & Indiana \\
\hline Osborn, G. L. & Iowa & Iowa & Iowa \\
\hline Osborn, T. C. & Iowa & New Jersey & Ohio \\
\hline Sanders, Eden & Indiana & Ohio & Indiana \\
\hline Scott, John M. & Iowa & Ohio & Ohio \\
\hline Shearer, Frank L. & Illinois & Unknown & Unknown \\
\hline Skiles, Fred & Iowa & Indiana & Indiana \\
\hline Smith, Charles A. & Pennsylvania & Pennsylvania & Pennsylvania \\
\hline Swanson, Adolph & Sweden & Sweden & Sweden \\
\hline Taylor, William (Milford) & Ohio & Ohio & Ohio \\
\hline Taylor, William (Grant) & Iowa & Ohio & Ohio \\
\hline Templeton, Milton E. & Iowa & Ohio & New York \\
\hline Templeton, W. F. & Iowa & Pennsylvania & Ohio \\
\hline VanPatter, Ben & Illinois & Illinois & Illinois \\
\hline VanPatter, Chas. & Iowa & Illinois & Illinois \\
\hline Wakefield, Sam & Iowa & Vermont & Ohio \\
\hline Warren, John F. & Illinois & England & Pennsylvania \\
\hline Warren, William & Illinois & Illinois & Kentucky \\
\hline Weston, C. E. & Indiana & Unknown & Unknown \\
\hline
\end{tabular}

Source: 1915 Iowa Manuscript Census, 1925 Iowa Manuscript Census

Seventeen (twenty-eight percent) of the farmers' fathers and eleven of their mothers (eighteen percent) had been born outside of the United States. The foreign places of birth given-Germany, the British Isles, and Scandinaviaare not surprising for the Midwest. ${ }^{25}$ 
The education of the farmers who subscribed for Wallaces' Farmer with Mills was more uniform. Of the fifty-nine individuals for which there is information about amount of education completed, fifty-six had received between six and nine years of common school. While sixteen had attended high school for some amount of time, only two recorded completing four years of high school. Two others mentioned attending college for one year each. There were no college graduates among the farmers who received the farm newspaper.

The subscribers to farm newspapers in the 1910s and 1920s were a varied lot. It appears that farm newspaper editors' claims that they reached all types and levels of farmer were correct. As William Mills walked or drove from house to house each winter, collecting subscription money and soliciting new subscribers, he visited a wide variety of farms. In Story County, landowners and renters, wealthy, average, and marginal farmers all received Wallaces' Farmer.

\section{CASE STUDIES}

Rural Midwesterners' records also show that readers of farm newspapers were diverse in terms of economic status, age, and place of origin. The following case studies give a taste of the background and characteristics of the

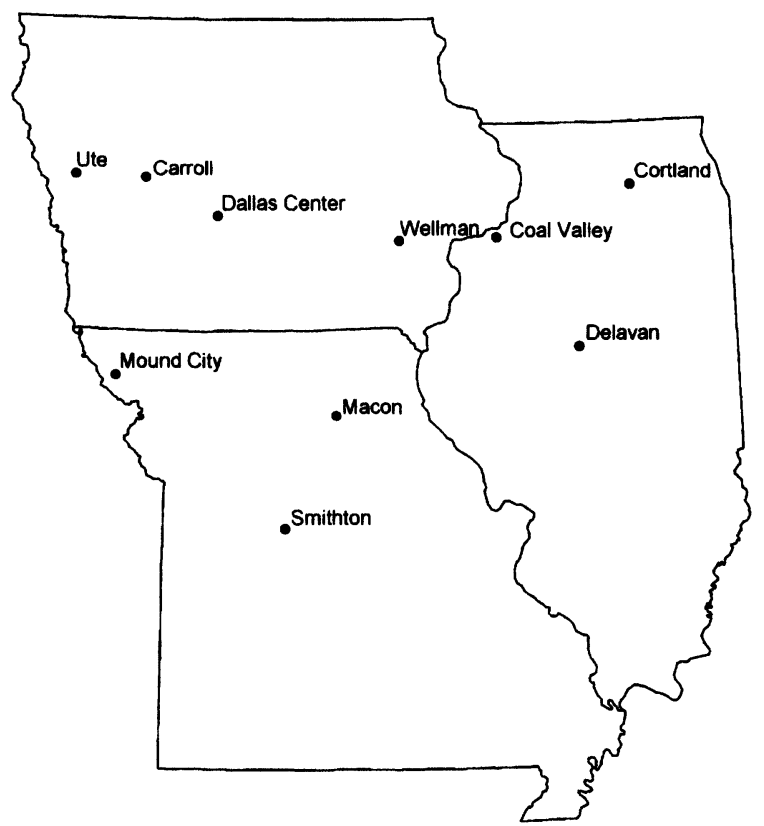

Map 2. Tour of the Lower Midwest 
variety of farmers who received farm newspapers. Together, they take us on a tour of the lower Midwest at the turn of the twentieth century. ${ }^{26}$ Map 2 shows the locations of towns near their farms. The tour begins with John Campbell Bailey, the farmer from the introduction to chapter three.

John Campbell Bailey was born on October 23, 1833 in White Church, County Down, Ireland. His parents brought his two brothers, one sister, and him to the United States in 1849 . His family was part of the great migration to America in response to the Irish potato famine. The family spent thirtyfive days on a boat from Belfast to New York, took the Erie Canal to the Great Lakes, and then sailed to Chicago. They rode a wagon west across Illinois from Chicago to the Mississippi River at Rock Island. During their first two years in America, his father worked as a stonemason and Bailey himself worked as a hotel porter in Rock Island. In 1951, his father bought land in Rural Township and the family settled there. ${ }^{27}$

Bailey married Mary Harsha in 1859. She gave birth to two sons and two daughters before she died in 1871. Two years later Bailey married Martha Wilson, who bore him two more sons and one daughter. Bailey and his children raised oats, wheat, and corn on the family land. They fed some of their crops to hogs and cattle and sold some of it in the Quad Cities. By 1880 , he owned 176 acres and his farm was worth $\$ 7,200$ (or about $\$ 135,000$ in 2003 dollars). ${ }^{28}$ All the members of the family were members of the local rural United Presbyterian Church where he served as an elder. Bailey kept a diary from 1867 to his death in 1923 and recorded all his correspondence there, including periodical subscription renewals and other remarks about reading material. Those diaries are now owned by the Rock Island Historical Society, and a copy is kept at the Illinois State Historical Library.

Bailey recorded paying for a subscription to the Iowa Homestead in 1896,1898 , and 1899. Unfortunately, there is little evidence of what he did with it. When he stopped getting the Homestead is clear, for his entry for January 11, 1900 reads: "I tinkered around \& wrote a letter for the Homested [sic] at Des Moines \& will get it changed to W. R. McElwain \& I sent 1.00 to pay for it for $1900 .{ }^{29}$ Bailey also subscribed to several national farm papers for longer periods. He faithfully renewed subscriptions to Farm and Fireside from 1886 to 1910, Farm Journal from 1904 to 1908, and Farm Press from 1907 to $1920 .^{30}$

Bailey and his family were active readers. He subscribed regularly for the local Rock Island Union, but he also tried several different local papers at different times: the Moline Review-Dispatch, the Davenport Times, and the Orion Times. He subscribed to several Chicago papers: the Chicago Journal and the Chicago Tri-Weekly Journal. He also paid to receive the 
Youth's Companion and the women's fashion magazine The Delineator. Unlike John Sanborn, covered at the end of the last chapter, Bailey does not seem to have been interested in subscription clubbing offers. He usually ordered papers and magazines individually by sending post office money orders directly to each periodical's publisher.

An elder in the United Presbyterian Church for over twenty years, Bailey also subscribed heavily to Christian periodicals. He renewed his subscription to the Christian Instructor every year between 1880 and 1915. He also received the United Presbyterian, the Evangelical Repository, Bible Teacher Quarterlies, and the Youth's Evangelist. He also bought Christian books such as Foxe's Book of Martyrs, Word and Works, and Rev. Hick's Almanac. Such publications provided ballast for his identity as an Evangelical Christian and ideas for his work in the church. ${ }^{31}$

According to the categories outlined in the discussion of William Mills' subscription list, Bailey was a landowner of average means. While he was born in Ireland, by the end of the nineteenth century had worked his way into the ranks of comfortable farmers in Illinois. A significant part of his family's life in America was reading, as he paid to receive local newspapers, farm newspapers, magazines, and Christian publications.

About seventy miles due west of Coal Valley is Lime Creek Township in the northwestern corner of Washington County, Iowa. At the turn of the twentieth century, one might ride the Rock Island and Pacific Railroad from Rock Island to Muscatine, then take the Burlington, Cedar Rapids, and Northern Railroad to Wellman, near the home of Isaac N. Carr. ${ }^{32}$ These railroads did not exist when Carr moved from upstate New York to Iowa with his parents in 1843 . He was seven years old that year. By the age of sixteen, he was an orphan. His mother had died in 1849, and in 1851 his father headed west and was never heard from again. As a result, his formal education ended after nine years of common school. He began working for a nearby farmer and saving up money to purchase land. In 1857 he borrowed money and bought land in Lime Creek Township. The next year he married Elizabeth Taylor, but she died in 1861 while giving birth to their only child, Harvey. Carr left Iowa to fight under Grant and Sherman, then returned to Washington County and married Elizabeth's sister Margaret in 1865. Margaret gave birth to eleven children, all but one of whom survived. Carr was a lifelong member of the Methodist Episcopal Church. He kept a fairly detailed diary from 1874 to shortly before his death in $1923 .{ }^{33}$

Carr was a successful farmer. His five sons helped him raise corn, wheat, oats, hay, and potatoes. By 1880, he owned 240 acres of land valued 
at over nine thousand dollars. He owned eighteen horses, sixteen cows for milk, thirty-four other cattle, over one hundred swine, and one hundred forty chickens. In 1894, his holdings had increased to 380 acres; in 1899, the county assessed his land at fifteen thousand dollars (over $\$ 300,000$ in 2003). Carr's farm was quite prosperous. ${ }^{34}$

Two pieces of evidence show that Carr received the Iowa Homestead. First, an annual subscription renewal letter was mailed to him sometime before his subscription ran out on April 28, 1897. ${ }^{35}$ Second, on November 24, 1895 , he wrote the following on the inside of the front cover of his diary:

\begin{abstract}
Rect to clear Seed Potatoes from Scab taken from the Iowa Homestead of November 221895 -Soak the potato one hour \& a half in a solution of corrosive sublimate made by dissolving $2 \mathrm{oz}$ of the poison in one gal of hot water $\&$ then add 14 gals of water before using. This will only kill the disease on the potato but will not prevent it if planted in soil already infected with scab.

I. N. Carr a nice cool calm sunny day $\&$ Sunday ${ }^{36}$
\end{abstract}

Carr also subscribed to the local Washington County Press and the Washington Democrat, as well as two newspapers from cities: the weekly edition of the New York Sun and the Chicago Weekly News. His membership card for the Wellman library and a copy of the U. S. D. A. publications list were both with his papers. ${ }^{37}$

By the end of his life in 1923, Carr owned over four hundred acres and had over fifty thousand dollars in assets (over half a million dollars in 2003). ${ }^{38} \mathrm{He}$ was certainly wealthy far above the average landowner in the early twentieth century. But like John Campbell Bailey, his less wealthy neighbor just across the Mississippi, he subscribed to the Iowa Homestead. His copying of passages into his diary suggests that he subscribed to receive the useful farming information the farm newspaper provided.

In the early twentieth century, one could take a number of combinations of trains northwest from Washington County to Des Moines. Then, traveling west of Des Moines on the Cedar Rapids and Pacific Railroad, after about twenty miles one could stop in Dallas Center, near where George and Lucy White lived. The Whites, who were discussed in the previous chapter, were readers of Wallaces' Farmer and other farm newspapers. They were established, landowning farmers, but they were not incredibly wealthy. Lucy White read farm newspapers for their information on chickens. Like I. N. Carr, she subscribed to them for their useful agricultural information.

Thirty miles northwest of Dallas Center the Cedar Rapids and Pacific line met the Chicago and Northwestern Railroad. Thirty miles due west on 
the latter road was Carroll, the county seat of Carroll County. May Bennett Harshbarger and her husband Harry lived not far from Carroll. May Bennett was born in 1880 in Carroll County and grew up on the family farm. After attending a one-room school and completing eighth grade, she attended the Normal Institute in Carroll for one year. Like Lucy White, she taught in rural schools before she was married. Between 1898 and 1910, she taught in several schools in western Greene County and eastern Carroll County. She also wrote several articles for the Des Moines Register and the Normal Instructor about the importance of rural education and methods for teaching farm children. In 1910 she married Harry Harshbarger and moved to the 80 -acre farm he rented in Glidden Township, east of Carroll. They had two children, Helen Louise, born in 1914 and Laurence H., born in $1921 .{ }^{39}$

Harry and May were renters for over ten years. Both the 1915 Iowa Census and the 1920 Federal Census list Harry as a renter. Only in 1923 did the township plat list him as a landowner: he owned eighty acres and rented eighty more. The Harshbargers were not extremely prosperous in the 1910s. In 1914, Harry's total earnings were listed as eight hundred dollars (worth about fourteen thousand dollars in 2003). His livestock was limited: thirteen cows, six horses, and eight hogs with a total worth of $\$ 1275$. Still, he was "upwardly mobile," as he had entered the ranks of landowners by the early 1920s. ${ }^{40}$

May Harshbarger kept detailed account books noting her purchases of food, medicine, clothing, and other household goods. Between 1911 and 1914, she also recorded payments for subscriptions to Wallaces' Farmer, Successful Farming, and the daily Drover's Journal. It is interesting that she ordered, or at least kept track, of these subscriptions, for she did not note other farm expenses. Did Harry keep separate account books to track the farm expenses? It may mean in the Harshbarger family, periodical subscriptions were seen as household expenses, even if they were farm newspapers. It could also mean that only May read them and that Harry was not interested. She also noted paying for subscriptions to the Chicago Inter Ocean, the Denver Post and the Kansas City Star. ${ }^{41}$

There are other indications that May Harshbarger was an avid reader. She was a charter member of the Goldenrod Magazine Club, formed on December 7, 1901. Dues were originally set at sixty cents a year, and this money purchased subscriptions to magazines. Members circulated each issue so that everyone could read it. The club also paid for the postage on books from the State Traveling Library in Des Moines. (Do not confuse this type of reading club with group subscription clubs. Reading clubs pooled 
money in order to purchase a subscription to a publication that was then circulated among its members. Group clubs were a way to get more people to subscribe to a periodical, not fewer.) Harshbarger remained a member until 1947 , when the group disbanded, supplanted by the local public library and members subscribing for their own issues of magazines. ${ }^{42}$

May and Harry Harshbarger are an example of renters who received a farm newspaper. Their income was significantly lower than that of John Campbell Bailey and Isaac N. Carr, and it was lower even than the Whites.' Still, they found farm newspapers, city newspapers, magazines, and other reading material a necessary part of their lives. It may be that they read Wallaces' Farmer and other farm papers because they were upwardly mobile. As they put into practice farm newspapers' practical suggestions, they accumulated enough capital to leave the ranks of renters by buying land. After Harry's death in 1926, May decided to stay on the farm and manage its operation while raising her two children. She kept detailed account books religiously from 1924 to 1951 .

Monona county is about forty miles due west of Carroll County. The western boundary of Monona county is the Missouri River; St. Clair Township sits on its eastern edge. St. Clair township was the home of the Cummins family farm. Dan Cummins was born in 1877 in Ute, Monona County, Iowa. His parents were born in Indiana, but they had moved to Iowa in $1868 .{ }^{43}$ On June 29, 1904, he married Myrtle Chase. He described the event in his diary as follows: "This day of all days Drove down to Charlie Chases got oldest girl drove to Ch. Oak \& Married her." 44 Dan and Myrtle Cummins raised three sons and two daughters.

The Cummins family grew corn, hay, and oats and raised cows, hogs, and chickens. In 1905, Dan paid property taxes on 54 acres assessed at $\$ 490$. The 1915 Iowa State Census recorded that his profit for 1914 was $\$ 1,380$ (about $\$ 24,000$ in 2003). While his farm was worth $\$ 11,000$ (about $\$ 193,000$ in 2003), it was mortgaged for about a third of its value. By 1919 , Cummins had enlarged his holdings slightly and made them contiguous; he owned 109.5 acres. Cummins was a respectable farmer. He was by no means wealthy. ${ }^{45}$

Dan began keeping a detailed diary in 1904 and continued until 1959. In general, he recorded daily activities, big events, and payments in his diary. It reveals the kin and neighborhood networks in which the Cummins family lived. Dan worked for other farmers and hired men to help with his farm. He also noted when other family members, came to visit. He only occasionally mentioned what his wife was doing: when she was sick, was having a child, or doing washing. For long periods, especially in 1907, Myrtle kept 
the diary. She consistently wrote both what her husband was doing and what she was doing. ${ }^{46}$

Cummins recorded his purchases of reading material on the account sheets in the back of his diary. He paid for both the Iowa Homestead and the national farm newspaper The Breeders Gazette throughout the 1910s. He began recording payments to Wallaces' Farmer in 1919, but these payments were much larger than a subscription cost. They were probably for advertising. It appears that he advertised in all three of these farm papers in 1919.47 Between 1910 and 1920, Cummins also subscribed to local papers from five surrounding towns: Ute, Charter Oak, Mapleton, Moorhead, and Sioux City.

Dan Cummins was a moderately successful land-owning farmer in Western Iowa. While less wealthy than Isaac Carr and John Campbell Bailey, his existence was comfortable for the early twentieth century. Like them he found local and farm newspapers useful for his farm operation and for his life.

After visiting the Cummins family, one could travel the final fifty miles from Ute to Sioux City on the Sioux City and Pacific railroad. If one boarded a barge there one could float down the Missouri River towards the state of Missouri. After about two hundred miles on the Big Muddy, a barge would reach Holt County, Missouri, just northwest of St. Joseph. A farm outside of Mound City, Missouri, was the home of John A. Sanborn from 1899 to 1902. The previous chapter described Sanborn's reading habits, including his use of Iowa Homestead clubbing offers. Like Lucy White, Sanborn was not a marginal landowner, but neither was he very wealthy. Sanborn and his family moved eighty miles west to Kansas in 1902, then two hundred miles back east to Macon County the next year.

The town of Macon is about seventy miles north of the Missouri River as the river runs East through the middle of the state of Missouri. The town of Smithton in Pettis County, Missouri is just about the same distance south of the river. At the turn of the twentieth century, one could take the Missouri, Kansas, and Texas Railroad southwest from Macon to Sedalia (home of the Missouri Ruralist from 1902 to 1910) and then walk several miles east to Smithton. Louis M. Monsees was born on a farm outside Smithton in 1858. His parents were German immigrants who had eleven children and whose farm was primarily a horticultural operation. Louis was the youngest, and he moved off the home farm when he came of age in 1879 to start a livestock breeding business. After a short stint raising hogs, he began breeding purebred jacks and jennets, or male and female donkeys. He married in 1890, and his wife Rickey gave birth to four children. Three sons survived: Nicholas, Deyo, and Kalo. ${ }^{48}$ 
Monsees was a keen judge of jacks and a shrewd businessman. His operation prospered. One of his jacks was named grand champion at the Chicago World's Fair in 1893, at the St. Louis World's Fair in 1905, and at the Panama-Pacific Exposition in San Francisco in 1915. He advertised his semiannual jack and jennet sales in both national and regional farm newspapers. His 1912 sale, advertised in the Breeder's Gazette, the Missouri Ruralist, the Iowa Homestead, and Wallaces' Farmer, featured over sixty jacks and jennets. He subscribed to these farm newspapers and more. Buyers wrote him from as far away as Cuba, Canada, Australia, Mexico, Brazil, and South Africa. ${ }^{49}$

Monsees was an exceedingly wealthy farmer and breeder, and he was celebrated as such by feature articles in the Missouri Ruralist. The Ruralist regularly reported on Monsees's sales, and the annual figures are staggering. In 1906, a single sale brought in $\$ 31,985$ (about $\$ 625,000$ in 2003). Four years later, one sale made twice that amount. In 1906, Monsees owned 156 acres in two townships in Pettis county. Twenty years later, he owned over 440 acres, and his wife owned 73 acres. (It is unclear why the land was entered in Rickey Monsees' name. It is possible that they were divorced or that he titled the land in her name for a tax advantage. $)^{50}$

The next reader was every bit as wealthy as Monsees. After backtracking fifty miles on the Missouri, Kansas, and Texas Railroad, one could switch to the Chicago and Alton Railroad. After the Chicago and Alton crossed the Mississippi at Louisiana, Missouri, one could stay on the train another 120 miles until it reached Tazewell County in central Illinois. A farm outside Delavan, the county seat of Tazewell County, was the home of Ralph Allen in the late nineteenth and early twentieth centuries. Ralph Allen was born in Massachusetts in 1854 of parents who had both been born in Rhode Island. The entire family moved to Illinois in 1869 . The family was remarkably wealthy: in 1880 Ralph's father, J. B. Allen, owned 490 acres of Tazewell County land, his farm was worth nineteen thousand dollars (almost $\$ 350,000$ in 2003), and his income for 1879 was two thousand dollars. ${ }^{51}$ Ralph attended private schools and then attended the Illinois Industrial University (later the University of Illinois at Urbana-Champaign). After graduating in 1877, he returned to farm 250 of his father's acres. In 1879, married Ada Eaton, who was from Delavan. Ada gave birth to ten children between 1880 and $1902 .{ }^{52} \mathrm{~J}$. B. and Ralph Allen went into business together, raising and selling pure-bred Jersey cows that they advertised in the national farm newspaper The Breeder's Gazette. Ralph Allen also raised sheep, hogs, and chickens. In 1918 , he bought a nearby 560 acre farm, mortgaging it for sixty-one thousand dollars (worth over $\$ 800,000$ in 2003). Since he was willing to take on that much debt, his income and accumulated capital must have been enormous. ${ }^{53}$ 
Ralph was also active in agricultural affairs outside the family farm. By 1888, he was one of the directors of the Tazewell County Farmers' Institute. He attended dozens of county and state fairs and county and State Farmers' Institute programs. In 1898, 1900, and 1909 the Governor of Illinois named Allen an Associate Delegate to the Farmer's National Congress. He was an expert on soil experiments, corresponding with Cyril G. Hopkins, a professor in the College of Agriculture at the University of Illinois about soil experiments, bacteria, and other topics. In 1902 and 1903 he wrote several short pieces for the Prairie Farmer on soil, conservation, and seed corn. Multiple clippings in the collection of his papers suggest that he was a reader of the Prairie Farmer, as well as a writer for the paper. ${ }^{54}$

It appears that Allen also read several local newspapers, as there are issues of the Peoria Evening Journal and the Delavan Times Press among his papers. He also wrote a letter to the editor of the Bloomington, Illinois Pantagraph in 1921. It appears that he read several farm newspapers as well. In 1884 he sent The Breeder's Gazette an engraving of one of his cattle as a possible illustration for the paper. ${ }^{55}$ In the 1920 s, he submitted an article to two national farm newspapers: the Drover's Journal rejected it, but The Country Gentleman accepted it. In 1911 he wrote a letter to the editor of the New York American. Finally, as Director of the Fourteenth District of the Illinois Farmers Institute, he passed out pamphlets with the names of Institute's officers and directors. The back of this pamphlet advertised the "Illinois Farmers' Institute Free Library," a traveling library of about fifty books on "agriculture, domestic science, history, biography, nature study and general literature suited to every member of the family." Groups could bring one of these collections to their community for six months, as long as their application was "endorsed by the president and secretary of the Farmers' Institute of the county in which the community is located." 56

Ralph Allen was an extremely prosperous farmer in a prosperous region of Illinois. However, unlike the other wealthy farmers described-I. N. Carr and Louis Monsees- he served both as a farmer and a producer of agricultural information for farm newspapers, farmers' institutes, and other agricultural institutions.

To reach the location of the final subscriber, we take the Chicago and Alton Railroad northwest from Delavan towards Chicago. Once in the metropolis, we change to the Chicago and Northwestern Railroad to travel west to Cortland, DeKalb County in northern Illinois. Several miles east of town is a 160-acre tract of land in Section 23, Cortland Township. Unfortunately, I have not been able to locate the name of the farmer who rented this tract of land between 1909 and 1914. William Settle's widow 
owned the land, but her first name has also been elusive. The anonymous renter's account book has been preserved, however, and it reveals that the individual received both the local daily newspapers and the Prairie Farmer. ${ }^{57}$ The Settle Farm Day Book provides further support for the proposition that renters received farm newspapers.

Our tour of readers' farms in the lower Midwest has taken us to seven farms in Iowa, Missouri, and Illinois. Counting the two discussed in the previous chapter, nine readers of farm newspapers have been examined. These farm families had different backgrounds, they operated under different circumstances, and they succeeded in different degrees. But they all subscribed to regional farm newspapers. Although they owned different amounts of land, made different amounts of money, came from different ethnic backgrounds, and had attained different amounts of education, these farmers all saw farm newspapers as important to their lives and to those of their families.

A large proportion of rural Midwesterners received and read farm newspapers. These publications were aimed specifically at country people and hoped to instruct them in how to farm better and how to live better. My research suggests that farm newspaper editors' claims that their papers reached all levels of rural society were probably correct. Rural Midwesterners of all economic, ethnic, and educational backgrounds received farm newspapers.

Thus far this book has made several observations. Midwestern farm newspapers expanded in size and circulation during the "Golden Age of Agriculture" from 1895 to 1920 . By the latter date, a majority of rural Midwesterners received at least one farm newspaper. The editors and publishers of these publications, however, were not normally farmers. Publishers were typically town people who had risen to ownership through the ranks of regular newspaper journalism. Editors usually had more farming experience, but they also often lived in cities or towns. Midwestern country people subscribed to a large variety of newspapers, books, and magazines. They read many publications aimed at city people and used what they read to maintain their communities, to improve their farming, and to fill their lives with entertainment. Farmers of all types subscribed to and read farm newspapers.

It appears that the editors and publishers of farm newspapers, living in cities and enjoying a more prosperous life than country people, had more in common with urban social reformers than their audience of country people. As a result, Midwestern farm newspapers conveyed messages that rural Midwesterners did not always share. The next chapters consider farm newspapers' recommendations about three social institutions vital to rural lifethe rural church, the country school, and the farm family-and rural Midwesterners' response to that advice. 


\section{Chapter Five}

\section{"Innumerable Little White Churches": The Rural Church and the Midwestern Farm Press}

The country church has sought man through the forests and across deserts. It has built innumerable little white churches on the country cross-roads for him to worship in. It has baptized his children, taught them, married them and buried them. It has striven to save their soulsstriven earnestly and valiantly, sometimes heroically. It has done everything in its power to pave the farmer's road to glory land; but it has paid so woefully little attention to his road to the nearest village.

- H. W. Graham, Editor, Missouri Ruralist ${ }^{1}$

The rural church has always been a vital institution for American country people. Worship was an integral part of life for the most groups of Native Americans. Likewise, religion was foremost in the minds of many of the first Europeans in Spanish America, New France, and New England. As Europeans moved to the interior of the continent, French and Spanish priests (and later, Methodist circuit riders) went with them. Even in the late nineteenth and early twentieth centuries, most farmers did not work on Sunday, except during the most critical times of planting and harvesting. The day was usually taken up with attendance at religious services and visiting with friends and family. Robert Swierenga has described the many community roles performed by the rural church:

The church was more than a religious meeting place; it was a cultural nest, integrating families, social classes, and nationality groups. It gave members a cultural identity and status and socialized them into the community. .. [ [Rural churches] provided charity and aid in times of sickness and disaster, educated children, offered recreation and leisure activities, facilitated marriages, consoled the grieving, buried the dead in the adjacent cemetery, and sought to legislate morality through political 
action.... Among immigrant groups, churches actually built communities by attracting newcomers. Rural life truly was church centered. ${ }^{2}$

These activities persisted well into the twentieth century. Members of the Country Life Commission stated that "the church is fundamentally a necessary institution in country life." ${ }^{3}$ In 1926, there were still over 150,000 churches in rural areas of the United States. ${ }^{4}$

The term "rural church" describes churches in the open country, as opposed to churches in towns or cities. The rural church in the Midwest at the turn of the twentieth century was a neighborhood institution serving the farmers surrounding it. Among rural churches, however, there was great diversity of experience. Rural churches were of widely varying sizes, denominations, and traditions. Roman Catholic, Presbyterian, and Lutheran churches required priests or pastors to attend a denominational seminary. A large number of other denominations, however, did not require a formal education of ministers, including Methodists, Baptists, Disciples of Christ, and many Evangelical or Fundamentalist Protestant sects. Some rural congregations were part of a denominational hierarchy; others were loosely associated with a general conference of churches; still others were independent. Diverse ethnic identities existed within denominations, including German and Norwegian Lutheran churches and German and Irish Roman Catholics. Styles of worship and even languages of worship varied greatly. The Buck Creek Methodist Episcopal Church and the Immaculate Conception Roman Catholic Church in Delaware County, Iowa were both rural churches, but they differed in almost every other particular. There was not only one type of rural church or one rural church experience. ${ }^{5}$

The lower Midwest at the turn of the twentieth century stood at the intersection of several American denominations' areas of strength, and a wide variety of churches were spread throughout the three states. A large percentage of members of churches in northern Illinois and northeastern Iowa were Roman Catholics. North central and northeastern Iowa was the southern end of a large area of Lutheran dominance that included Minnesota and the Dakotas. Southern Illinois, southern Iowa, and northern Missouri were part of a belt of Methodist strength that reached to the east through Indiana, Ohio, Kentucky, and West Virginia. Finally, southern Missouri was the beginning of the Baptist "Bible Belt" of the South. In Iowa and Illinois there was a significant Lutheran minority; in all three states there were significant numbers of Presbyterians and Roman Catholics. ${ }^{6}$

How many of these churches were in rural areas? How many members did they serve? According to the 1926 U. S. Religious Census, over fifteen thousand churches served nearly two million members in Iowa, Illinois, and Missouri. (See Table 17.) This was the first year that the Census Bureau 
Table 17. Churches and Church Membership in Urban and Rural Areas in 1926

\begin{tabular}{lll}
\hline \multicolumn{2}{l}{ Number of Churches } \\
\hline & Urban $^{*}$ & Rural \\
\hline Illinois & 4,078 & 5,478 \\
Iowa & 1,396 & 3,779 \\
Missouri & $\underline{1,800}$ & $\underline{6,151}$ \\
Total & 7,274 & 15,408 \\
\hline Entire U. S. & 64,290 & 167,864 \\
\hline
\end{tabular}

Church Membership

\begin{tabular}{lllll}
\hline & Urban* & Rural & $\begin{array}{l}\text { Total } \\
\text { Population } \\
1920\end{array}$ & $\begin{array}{l}\text { Number } \\
\text { of Farms } \\
1920\end{array}$ \\
\hline Illinois & $2,633,916$ & 729,469 & $6,485,280$ & 237,181 \\
Iowa & 486,122 & 594,036 & $2,404,021$ & 213,439 \\
Missouri & $\underline{1,581,278}$ & $\underline{613,955}$ & $\underline{3,404,055}$ & $\underline{263,004}$ \\
Total & $4,701,316$ & $1,937,460$ & $12,293,356$ & 713,624 \\
\hline Entire U. S. & $35,126,927$ & $19,386,734$ & $105,273,049$ & $6,448,139$ \\
\hline
\end{tabular}

* "Urban territory includes all cities and other incorporated places which had 2,500 inhabitants or more in $1920 \ldots$. rural territory comprises the remainder of the country."

Sources: Number of Churches and Membership Statistics: United States Bureau of the Census, Religious Bodies: 1926 (Washington: GPO, 1930), v. 1, 132-133. Census figures: 1920 United States Census, Historical United States Census Data Browser, http://fisher.lib.virginia.edu/census; internet; accessed 30 September 2004.

divided its totals into rural and urban. The Census Bureau distinguished urban from rural by its rule of thumb: churches were classified as "urban" if they were in incorporated areas of more than 2,500 in 1920. Therefore the report did not distinguish churches in the open-country from those in small towns. Still, its division provides a rough estimate of the number of open-country churches and the number of people they served at the turn of the twentieth century.

Rural churches usually employed only one staff member: the pastor. Members' subscriptions raised funds for the pastor's salary and other church expenses, and farmers frequently paid in kind. Ministers often had little cash and many potatoes, chickens, logs for their fire, and other goods. Some ministers lived in the open country, some lived in a nearby town and rode out to the church building for Sunday services and a midweek prayer meeting. A number of churches only opened the building for Sunday School and the 
Sunday morning worship service. In addition, some pastors served more than one rural church, so there was only a "preaching service" every other week or once a month.

The character of American Christianity was changing at the turn of the twentieth century. In the late nineteenth century, Evangelical Protestantism was shaken from its position of dominance in United States society. Urban growth, the arrival of new immigrant groups, and new scholarly intellectual currents such as the theory of evolution and higher criticism of the Bible all challenged Protestant Churches. As a result, Evangelical hegemony declined, and a new era of pluralism in religion began. ${ }^{7}$

Rural churches were also disturbed by the demographic, religious, and economic shifts of the late nineteenth and early twentieth centuries. The beginnings of outmigration from rural areas strained many country churches; when country people moved to towns and cities, rural churches lost their participation and financial support. Mainline Protestant churches' dominance was challenged by Roman Catholic churches and new evangelistic Protestant sects, such as smaller Baptist groups and Pentecostal churches. Country churches in some economically distressed areas actually withdrew to towns, and the rural people they left behind felt betrayed. ${ }^{8}$

Census figures suggest that these two processes affected rural areas of the Lower Midwest as well as the rest of the country. There are churches from significantly more denominations listed in the 1926 Religious Census for Iowa, Illinois, and Missouri than there were in 1906. The latter census also shows large gains for the Roman Catholic Church in those states, although for Illinois and Missouri, it is unclear whether the growth was urban or rural. In addition, the 1915 Iowa State Census lists a number of churches in denominations not reported in the 1905 census. $^{9}$

Between 1895 and 1920, Midwestern farm newspapers increasingly reported these changes and suggested ways of dealing with them. Editorials suggested ways to respond to these changes. Feature stories praised the triumphs of rural congregations that had taken the papers' advice. Letters to the editor commented on these recommendations for the rural church. In all these ways, the farm press became a public forum for the discussion of the "rural church crisis." 10

Midwestern farm newspapers' treatment of the rural church provides a good introduction to the non-agricultural content of these papers. This chapter will examine the coverage of the rural church in the Midwestern farm press between 1895 and 1920. It will then consider why farm papers gave these recommendations. Finally, it will explore the attitudes of readers to the papers' description of the rural church. 


\section{COVERAGE OF THE RURAL CHURCH CRISIS}

The coverage of the rural church crisis in the four farm papers studied falls into three periods: the discovery of the crisis, dealing with the crisis, and the fading of the crisis. From 1895 to 1908, farm newspapers printed their first comments about religion and the problems of the rural church. Then, between 1909 and 1916, these papers printed a large number of articles, editorials, and letters describing the rural church crisis and presenting solutions to it. After 1916, the farm papers' coverage of the crisis decreased sharply. Articles and editorials about the rural church continued to appear, but farm newspapers' treatment became less focused and less dogmatic than previous years.

\section{Discovering the Rural Church Crisis, 1895-1908}

The first distinctive period of coverage of the rural church in farm newspapers began in 1895 and continued to the end of 1908, when President Theodore Roosevelt appointed the Country Life Commission to investigate conditions in rural areas. During these years, farm newspapers considered the situation of religion in rural areas and exhibited mild concern about the future of the rural church.

Wallaces' Farmer, edited by former Presbyterian minister Henry Wallace, led the way in providing coverage of religion. Henry Wallace was concerned for all aspects of the farmer's life: economic, intellectual, moral, and spiritual. Wallace's concern for the spiritual and moral elements of rural life manifested itself in Wallaces' Farmer's weekly "Sabbath School Lesson." This column began as a one-time article in July of 1898 . Wallace mused on his church's Sunday School lesson about the Old Testament prophet Elijah, arguing that Elijah had been a potent political reformer, not just a moral teacher. Readers apparently liked the piece. By the end of the month, Wallace had begun writing a weekly commentary on the International Sunday School Lesson, a nondenominational curriculum used by many rural churches. By 1901, the "Sabbath School Lesson" was a weekly department with its own multi-column title. It presented in plain terms what Wallace saw as the meaning of the text, be it Jesus' teachings, Old Testament History, or another topic. ${ }^{11}$

The Iowa Homestead also saw religion as an appropriate subject for farm newspapers to address. In the last issue of 1903, the Homestead announced that it was going to provide its own commentary on the International Sunday School Lesson. The first installment appeared the next week. Titled "Pleasant Fields of Holy Writ" and written by a Dr. Davis W. Clark, it presented the same type of exegetical and devotional comments offered by Henry Wallace. In the introduction of the new department, the 
editor of the paper argued that rural Midwesterners were more religious than those who lived in cities. Therefore, it was fitting for a farm newspaper to provide Biblical commentary:

It is appropriate, we think, that these notes should appear in the columns of an agricultural paper of so high standing as that of The Homestead. We have a feeling that somehow the people who live out in "God's open" get nearer to him than the dwellers amid the city pavements, and we never think that in basing our faith in any proposition on the religion which we believe to be characteristic of the average tiller of the soil, that we have made any mistake. For this reason we think our new department will find favor in the eyes of a number of Homestead readers. At any rate, they will realize we are leaving no stone unturned to give them, in these columns, the very best of that which will appeal to them from every side, whether it be agriculturally, intellectually, morally or spiritually. ${ }^{12}$

One might also wonder whether Pierce and the editor were anxious about the popularity of Henry Wallace's "Sabbath School Lessons" and were seeking to provide the same service in their publication.

The Iowa Homestead, the Prairie Farmer, and the Ruralist, however, were relatively silent on the question of the rural church crisis until 1909. Outside of "Pleasant Fields of Holy Writ," the Homestead's mentions of religion were confined mainly to "Our Home Department." Correspondents exchanged suggestions for how to best teach Sunday School and debated the merits of religious fiction. ${ }^{13}$ Several Homestead editorials celebrated the fundraising success of the United Methodist Church and suggested that Sunday be a day of rest for the entire family. Otherwise the rural church was not a concern for either owner James M. Pierce or his several different editors. ${ }^{14}$

There was only one editorial mention of the rural church in the Ruralist between its inception in 1902 and 1908. The editor of the "Home Department" noted that making money for the rural church was an "ever present problem," and described a successful Christmas Bazaar put on by her church. As part of its never-ending pursuit of more readers, however, the Ruralist did offer a free six-month trial subscription to The Christian Work and Evangelist, a nondenominational religious paper published in New York City. The only Prairie Farmer articles that mention religion exhorted readers not to make Sunday oppressive for their children but rather to use the Sabbath rest as a true time of family and spiritual renewal. ${ }^{15}$

The rural church was much more on Henry Wallace's mind. An 1895 editorial in Wallaces' Farmer compared it to other open-country institutions. $\mathrm{He}$ argued that rural society needed farm clubs to bring farmers together. A 
forum was necessary where they could talk about mutual interests and provide for a more lively social life. The local church congregation and the local political party organization brought farmers together, but they were too narrow to organize the rejuvenation of rural social life:

The country church furnishes social enjoyment but the farmer's life is broader than his church; political meetings add to the diversion but no matter how strong a politician he may be he is a much broader man than his party. The Farmer's Club if rightly conducted takes in his wife and sons and daughters as well. ${ }^{16}$

He went on to assert that "there should be in every township, and preferably at the center, a building large enough for social as well as political meetings." These sentiments, made at the height of the Farmers' Alliance movement, described Farmer's Clubs as more important social institutions than rural churches or political parties. ${ }^{17}$

By the early twentieth century-after the collapse of both the Populist Party and the Farmers' Alliances-Wallace began to think that the rural church building might become this social center for the rural community. In a 1903 editorial he lamented farmers' movement from rural areas to towns in search of better school and church privileges. Outmigration weakened rural schools and churches, creating a vicious cycle. He argued that a better social life in the country "would go far to stop the exodus to the towns and maintain churches and schools." He then explained that the rural church could be central to this new life:

The country church should be a center of social life. There is no reason why it should not have its kitchen and apartments for holding meetings of the members or of the neighborhood. A church, whether in town or country, should be for use more than one day and one or two evenings in the week. ${ }^{18}$

The recommendation that the rural church should become a community center in order to keep rural people on the farm later became one of the central tenets of farm newspapers' coverage of the rural church.

A final editorial in Wallaces' Farmer picked up these themes but blamed farmers for the problems in rural churches. In 1906, Wallace argued that farmers should not move to towns to take advantage of better school and church privileges. Instead, they should stay in the country and improve the schools and churches there. "The way to make good country churches and encourage country preachers is to attend church, pay the preacher, take an interest in every good work that is going on, if not in your own denomination 
than in some one most nearly akin to it." ${ }^{19}$ Wallace both identified the problem and offered solutions to it. This type of writing about the rural church became common during the next period.

\section{Dealing With the Rural Church Crisis, 1909-1916}

The appearance of the Report of the Country Life Commission in 1909 focused public attention on the problems and promise of country life. It also promoted interest in the rural church crisis as one aspect of the country life problem. While some farm newspapers welcomed the report warmly, others printed negative responses and even ridiculed it. It is clear, however, that during the next eight years the Midwestern farm press turned intense scrutiny on churches in the rural Midwest. Farm newspapers delivered a number of proposals for dealing with the rural church crisis. Over one hundred fifty articles, editorials and letters in the four papers addressed the rural church, giving similar descriptions of the rural church problem and presenting similar solutions. Three themes organized these papers' recommendations for the rural church. Farm newspapers called for the church to be the social center of the community. They also emphasized interdenominational collaboration and downplayed doctrinal differences between churches. Finally, they called on the rural pastor to take on a new and wider role in the community.

Wallaces' Farmer again had many more editorials, articles, and letters about the rural church than the other three farm papers during this period. The paper's leadership is not surprising, as Henry Wallace had been a Presbyterian minister, had taught Sunday School regularly, and had already been writing the "Sabbath School Lessons" in the paper. He also was a member of the Country Life Commission, and it appears that his tenure on the Commission animated him to address the subject. Between early 1909 and his death in early 1916, the paper ran over eighty items that in some way addressed the rural church.

The first theme was a call for the rural church to become a social center. As Henry Wallace put it in Wallaces' Farmer, "the country church should be the center of the social life" of the community. ${ }^{20}$ Wallace wrote in a 1916 editorial that Christians should "organize churches with the main end in view of community betterment. . .." 21 He encouraged pastors and other church leaders to reject a "narrow" concentration on saving souls and increasing church membership in favor of serving the community. Suggestions for social activities included outside speakers, corn clubs, singing schools, lending libraries, and picnics. ${ }^{22}$

In addition to these editorial calls for the church to become a community social center, Wallaces' Farmer also reported on exemplary churches that had followed its recommendations. A January 1911 editorial pointed 
readers to the previous month's issue of The World's Work. The popular magazine had printed a story by M. B. McNutt on his efforts at a rural church in DuPage County, Illinois. McNutt had increased the membership of his church, the size of its building, and its influence in the community through a program of social events. These included a singing school, a baseball team, a youth group, a farmers' organization, and a women's club. Wallace praised the church as a shining example of what could be done, and the paper printed a speech by McNutt later that year. ${ }^{23}$ In addition, a 1914 feature article described the social activities of a rural church in Tama County, Iowa. ${ }^{24}$ Finally, the paper published letters from the pastors of three revitalized churches in Missouri, Illinois, and Iowa. ${ }^{25}$ These reports all give glowing accounts of the effectiveness of Wallace's prescriptions.

The Homestead's editorials in 1912 encouraged pastors to make church buildings "centers of community life and interest," by adding auditoriums for entertainments, kitchens for church suppers, and gymnasiums for young people's activities. M. B. McNutt also appeared in the pages of the Homestead, both in a report on a Rural Life Conference at the Iowa State College and a feature on his successful church. Finally, James M. Pierce, in his "Publisher's Views on Topics of the Times" praised a country preacher that had used the church building for talks on hog cholera, human health, and the care of the teeth. He concluded: "Let the country church take its part in keeping prosperity up to a high mark and in maintaining and restoring physical health; then its perpetuity and its usefulness are established beyond all question." 26 Like Wallaces' Farmer, the Homestead saw the social mission of the rural church as of utmost importance. ${ }^{27}$

The Prairie Farmer did not address the rural church until Clifford V. Gregory became editor in mid-1911. Gregory's interest in the rural church problem was revealed in a letter he wrote in 1910 to Successful Farming, a national monthly farm magazine. Among other things, it gave the same prescription provided in other farm publications: that the country church should be the center of its community. ${ }^{28}$ After he had become the editor of the Prairie Farmer, he ran several feature articles by Rex Beresford about the rural church. Beresford asserted that the country church had a responsibility to its entire community, not only to its members. He also argued that it should provide social activities for rural neighborhood. ${ }^{29}$

The Missouri Ruralist likewise saw social activities as a way of dealing with the rural church crisis. A 1912 editorial recommended that the country church provide recreational, literary, and social opportunities to its community to help keep farm children on the farm. Editor H. W. Graham stated his case in the eloquent words given at the start of this chapter. He suggested 
that a country church should open its doors three hours a day, not three hours a month. The purpose of the rural church, he argued, was to save country children not only for heaven but also for the American farm. ${ }^{30}$

These calls for the rural church to become a community center are somewhat mysterious. Social historians have long described the rural church as a social center for its community. ${ }^{31}$ If country churches already were community centers, why were Midwestern farm papers calling for them to take up the role as if it were something new? It appears that country churches had often served as social centers primarily-or exclusively-for their own members. The farm press meant for the country church to serve the entire rural neighborhood in which it was located, whether or not the families there were members of the church.

In order to provide these services to the community, denominational barriers had to be broken down and theological divisions de-emphasized. Interdenominational collaboration is the second theme in farm newspapers' recommendations for the rural church. In Wallaces' Farmer, Henry Wallace repeatedly urged rural churches to work together in order to carry out their social mission to the community. First, he called on pastors and churches of different denominations-even Roman Catholic and Protestant churches-to cooperate rather than to compete. One of the earliest statements is typical:

\footnotetext{
Where country pastors cover to some extent the same field there should be entire harmony and cooperation, no matter whether they be Catholic or Protestant, Calvinist or Armenian [sic]: for the differences between the sects are trifling compared with the great points of unity, the great essential doctrines in which they are all agreed. . . 32
}

In 1912, he recommended a non-sectarian, cooperative Easter service to which everyone in the community would be invited. An additional call for cooperation was made in "Prosperous Country Churches," an article about church buildings. The article described two communities in Iowa where only one church served its respective neighborhood. Both were able to build large and socially useful church buildings. On the other hand, a community that he does not name had three churches of different denominations. As a result "none of the churches can make much of a showing." Wallace suggested that the three churches cooperate in order to succeed like the first two communities. ${ }^{33}$

Church federation was one step further than cooperation. Henry Wallace used a striking anecdote to introduce the idea in 1914:

A kind providence, for example, through the medium of a benevolent cyclone, wiped out every church save one in a little town. The different 
denominations were obliged for the time being to combine in that one church until new churches could be built. Before they began to seriously undertake this new work, however, they found that they were so much happier and better off in the one church that they gave up the idea of building. ${ }^{34}$

Wallace suggested that lacking such providential weather patterns, several churches of different denominations could choose to share a pastor, building, and worship services. The members of each church would retain their denominational affiliation, organizational structure, Sunday School, missionaries, and mode of baptism. Two years later, Wallace again stressed federation, offering it as the cure for sick country churches. ${ }^{35}$

The Homestead also endorsed church federation. One article in 1910 noted that the Iowa Baptist Church Convention had considered federation as one way of dealing with the rural church problem. The author suggested that "the success of consolidation in school work would argue that the same practice applied to churches would have good results." 36 The 1912 conference on the rural church held at Iowa State College produced many calls for cooperation. M. B. McNutt recommended that in a community with three churches of different denominations, the three congregations should meet in one church's building for services and turn one of the other buildings into a community center for social activities. (The article did not report if $\mathrm{McNutt}$ said what should be done with the third building.) Another speaker called for the "obliteration of denominational lines." 37

In the Prairie Farmer, Rex Beresford suggested that weak country churches should federate. He decried the divisions of churches based on method of baptism or "the time of passing the collection plate," asserting that most rural communities could only support one church. He called on rural churches to unite to provide better religious and social services to their community. A farmer should not "jeopardize the immortal soul of his neighbor or the social life of the community" for the sake of doctrinal purity. Overall, it seems clear that Beresford was much more concerned for community social life than the salvation of souls. ${ }^{38}$ John F. Case of the Missouri Ruralist promoted a federated church in Barnett, Missouri, that was looking for a pastor. Case asked his readers if they knew anyone "big enough and broad enough" to be the minister of this new church. ${ }^{39}$

Farm newspapers accompanied these calls for cooperation with an overall de-emphasis of theology. Henry Wallace described differences in doctrine as unimportant and argued that they were carried too far. For instance, in July 1911 , he asserted that the pastor who "permits himself to engage in bitter controversy over points of doctrine which are not vital to the development of 
human character and salvation, will necessarily fail." The divisions between denominations were "mainly concerning non-essentials" and doctrinal differences were often "magnified out of all true proportion." 40 In a similar way, an editorial in the Missouri Ruralist condemned debates between pastors of different denominations, asserting that practicing what one preached was much more important than arguing over theology:

Instead of discussing one another's theology the religious world has hit upon the happier plan of practicing what it preaches. And thus it happens that, no matter what sort of baptism may be administered or whether salvation came before or after baptism, or whether close [sic] or open communion is the practice, the fruit-charity, patience, virtue, good works-is the same if the religion is a reality and not a sham.

The piece concludes, "Preachers who engage in these debates and laymen who encourage them with their presence should be restrained from running at large." 41 Rex Beresford of the Prairie Farmer also recommended that rural churches de-emphasize doctrine in order to unite to serve their communities' social needs. Noting that Jesus himself used examples from gardens and fields, Beresford suggested that rural pastors speak "more of grapes and plums and apple orchards and less of original sin; more of the beauty of clover fields and tasseling corn and less of total depravity." 42 Like leaders of American Universities at the turn of the twentieth century, farm newspaper writers viewed Christianity as a way of life, not a doctrine. ${ }^{43}$

One would not expect agricultural editors or writers hoping to reach country people of many different denominations to advance one denomination's agenda or belief system. However, the vehemence with which Henry Wallace and the other editors assailed denominational competition and doctrinal controversy is striking, especially in light of rural areas' traditional theological conservatism and strong attachment to denominational identity. ${ }^{44}$ It appears that these authors were blind to the fact that some readers might see their de-emphasis of doctrine as support for liberal doctrine.

It also appears that when Midwestern farm editors and authors described rural churches, they were thinking about mainline Protestant rural churches. Federation was only possible among churches that had embraced liberal theology and downplayed their doctrinal distinctives: usually the mainline Baptist, Methodist, and Presbyterian churches. It is impossible to think of a Presbyterian Church federating with an Assembly of God congregation at this time, though both had congregations in the rural Midwest. It is equally impossible to think of that Presbyterian church federating with a nearby Roman Catholic church. Farm newspapers' coverage of the rural 
church crisis flattened the diversity of rural religion by describing mainline Protestant churches as if they were the only type of rural church that existed, or at least the only type that mattered.

The third theme in Midwestern farm newspapers' coverage of the rural church involved new functions for its pastor. The Iowa Homestead praised country preachers for being community leaders in rural neighborhoods. It called on rural pastors to get to know agriculture to better serve their congregations. A 1911 editorial cajoled rural congregations to pay pastors well for their many services:

They marry our lovers, baptize our children, visit the sick, bury the dead, keep the churches alive, eat our chickens, are the victims of donation parties, are specially bored by book agents for their "inflooance" [sic] and they stand in the breach generally. They ought to be paid promptly, and not in dried apples and other refuse bric-a-brac, but coin of the realm. ${ }^{45}$

Other articles also put the pastor at the center of the Homestead's program for revitalizing the rural church. ${ }^{46}$

Wallaces' Farmer provided more extensive recommendations. In a March 1910 issue, a correspondent asked about "the relation of scientific agriculture to the country church." Henry Wallace replied that "we prefer to state the question a little differently, namely the relation of the country pastor to scientific agriculture." Wallace explained that the country pastor should be a leader in the neighborhood, should meet and befriend all members of the community, and should know something about agricultural methods. Neighborhood leadership, community service, and agricultural knowledge made up the new role that Wallace envisioned for the country pastor. ${ }^{47}$

First, editorials admonished rural pastors to become leaders in the neighborhood that they served. Wallace called the country pastor the "leading man in his community," the "first man in the community," and the "biggest man in the community." The articles rarely gave reasons why a pastor was qualified for such leadership roles. One piece asserted that the pastor's education and ability to communicate with large groups and with different kinds of people fitted him for leadership. Otherwise, the paper merely asserted that the pastor should be a community leader. As one editorial stated, he simply was the "natural leader of the community." 48

Wallace also recommended that the country pastor visit and befriend all the families in his community, not just the members of his church. Furthermore, the pastor should make contact with them without the intention of converting them to Christianity or getting them to join his church. 
His object should be to assist them in whatever manner they needed. ${ }^{49}$ Just as the church was to be a social center for the entire community, the pastor was to be a leader for the entire community.

Finally, Wallaces' Farmer instructed rural pastors to learn about agriculture in order to better serve their rural parishioners. The rural pastor must understand the everyday lives of farmers in order to apply the teachings of the scriptures to their situation. Henry Wallace explained that once a farmer "understands that the preacher knows something about farming, is a reader of farm literature, and a student of farm problems, and that he is in dead earnest about this, he will give him credit for all the theology that the preacher wishes to claim, and probably for a good deal more than he really has." For these reasons, Wallace promoted a Summer School in agriculture at Amherst College constructed specifically for rural pastors. ${ }^{50}$

Clifford Gregory agreed with this new role for the rural pastor. In his letter to Successful Farming, Gregory argued that the pastor of the country church should know agriculture and be a community leader. As editor of the Prairie Farmer, Gregory promoted a short course on agriculture for pastors put on by the Iowa State Agricultural College and Drake University. He also suggested that pastors should read a good farm newspaper regularly. Rex Beresford asserted that the rural pastor should learn agriculture and should take back his traditional role as community leader. ${ }^{51}$

Finally, John F. Case supported a community leadership role for the rural pastor in the Missouri Ruralist. He argued that "strong leadership is an essential in developing social life and co-operative work in a community. It's an easy matter to do things when people get together but first there must be someone to lead the way." The Ruralist reported on several rural pastors who had provided leadership to their neighborhoods in community betterment. ${ }^{52}$

By delivering these recommendations, authors failed-or refused-to recognize the diversity among rural churches in the Midwest. Pastors in mainline Protestant denominations performed different duties than priests in Lutheran or Roman Catholic churches or ministers in new, evangelistic churches such as the Assemblies of God. In some cases these church leaders already saw their rural neighborhood as their area of work. For instance, Roman Catholic Priests often worked to know and serve their entire parish. In contrast, evangelistic congregations saw the mission of the pastor as saving souls and ministering to church members. Farm paper editors and authors, many of whom were located in cities, either did not see these differences or did not believe they were important.

Thus, the program for the rural church presented in the pages of the Midwestern farm newspaper between 1908 and 1916 was threefold: the 
church should be the social center of its community, churches of different denominations should cooperate, and pastors should learn agriculture and take on leadership positions in their community. These themes were summed up by an Iowa Homestead editorial in 1913:

First, the church should take more direct interest in everyday affairs; second, there are, as a rule, too many churches, dividing the interest and the attendance until they reach almost the vanishing point; third, the pastor should be familiar with farm work by actual, personal experience. ${ }^{53}$

Editors saw these recommendations as connected; where there were multiple churches in a community, they must cooperate in order to become a social center. Social activities and collaboration would be made possible by the active leadership of a dynamic pastor.

\section{Fading of the Rural Church Crisis, 1916-1920}

In 1916, several things developments changed the four farm newspapers' coverage of the rural church. First, Henry Wallace died on February 22, 1916. Wallaces' Farmer changed slowly but perceptibly after his death as his son Henry C. Wallace assumed all editorial duties for the paper. One result was that the flagship for coverage of rural church issues, Wallaces' Farmer, ran fewer editorials and articles about the church. In addition, American citizens became more interested in the war that was devastating Europe and that would involve this country in early 1917 . For these reasons, the rural church crisis was mentioned less in all four of the papers studied, though it did not disappear completely. Farm newspapers' coverage of the country church lost the focus and sense of purpose it had enjoyed during the previous eight years.

Even after Henry Wallaces' death in February of 1916, Wallaces' Farmer continued to lead the other farm newspapers in the number of pieces concerned with the rural church. Henry C. Wallace's editorials still discussed the church as a social center, the importance of interdenominational cooperation, and the pastor's role as community leader, but they did so in less dogmatic terms than Henry Wallace's had. The new editor also considered different issues such as the differences between "native American" and immigrant churches, the use of Biblical versus agricultural illustrations in sermons, and where the parsonage should be built. ${ }^{54}$

The most popular type of treatment of the rural church in Wallaces' Farmer after 1916 was the "How We Did it Right" article. These were feature articles describing successful churches, often including several pictures of the church building, pastor, congregation, or social activities undertaken by the 
church. While these types of features were printed between 1908 and $1916^{55}$, these features became the bulk of farm newspapers coverage of the rural church between 1916 and 1920. During those years, Wallaces' Farmer published fourteen pieces on successful churches in Iowa, Illinois, and Missouri. These articles told how active pastors had made their churches appealing to farmers of all religious persuasions by providing a variety of social activities. ${ }^{56}$ Wallaces' Farmer continued to cover the rural church after 1916, but new issues complicated editorials, and feature articles were increasingly of the "How We Did it Right" variety.

The coverage of the rural church dropped off more precipitously in the other three farm newspapers studied. For instance, after 1916, the Iowa Homestead published only seven pieces about the rural church, most of them appearing in James Pierce's "Publisher's Views on Topics of the Times." In 1917, Pierce denied there was ultimately a rural church problem: "I often tire of statistics and theories about the country church and say to myself that country churches will not die when there are good souls, devoted to their religion, who do not intend to let the churches die." 57 When the United States entered the war, he dedicated one "Publisher's Views" installment to the problem of driving to church when Sundays were supposed to be "gasless." After the war, he ran two columns that predicted that the experience of war would rejuvenate the rural church. Finally, the paper did print one article on the Interchurch World Movement for church federation and an editorial promoting a conference at Iowa State College on the country church. ${ }^{58}$ Thus, the Homestead printed much less about the rural church after 1916, and what it did print addressed seemingly random religious issues. The elaborate program to address the rural church crisis of the previous eight years was gone.

The Prairie Farmer also returned to intermittent coverage of the rural church after 1916. A brief editorial announced that Dr. Charles I. Stewart of the University of Illinois had offered a $\$ 100$ prize to the church in Champaign County that did the "best work for the welfare of its community during the next year." Occasional feature articles praised the members of churches across Illinois for their community work. Editorials addressed "gasless Sundays" and the pay of pastors. In 1919, Gregory invited readers to address rural church problems; a number of readers sent him letters. The paper still supported community service and church federation, but it did so with less urgency. Increasingly, advice was delivered through the medium of the "How We Did it Right" story. ${ }^{59}$

The Missouri Ruralist likewise devoted less space to the rural church after 1916. Editor John F. Case's editorials commended Ladies Aid committees 
for supporting the rural church, described his hometown Sunday school, and recommended social activities. The paper also printed three "How We Did it Right" features, two of which covered C. R. Green's congregation in Harmony. Green's church had inspired a number of articles between 1909 and 1916. As it had in the other three papers, the rural church crisis faded from the pages of the Missouri Ruralist in the late 1910s. ${ }^{60}$

\section{WHY THESE RECOMMENDATIONS FOR THE RURAL CHURCH?}

The Midwestern farm newspapers studied had varying amounts of coverage of the rural church. Wallaces' Farmer had the most, the other three papers had about the same quantity. However, between 1909 and 1916, all four papers provided recommendations for the rural church that were strikingly similar. These concerned the rural church's role as a community center, the necessity of interdenominational cooperation in rural areas, and the role of the pastor as community leader. Why were farm newspapers so concerned about rural churches? Why did they give these specific recommendations? Two early twentieth century social movements influenced their coverage: the Country Life Movement and the Social Gospel.

The Report of the Country Life Commission was concerned with two aspects of the country life problem. The authors first addressed ways that farming could be made more profitable: farmers should organize and government should be attentive to their interests. The Report also addressed ways to improve rural life in order to keep country people from moving to cities. The country church was an important part of the Report's recommendations concerning rural social life. The sixty-five page document mentioned the rural church and rural pastors a number of times, including a three-page section specifically devoted to country churches. ${ }^{61}$

The Country Life Commission asserted that rural churches could not be left out of its rural reform program for two reasons: country life problems involved morality, and the rural church was a necessary institution for rural neighborhoods. The Report asserted that there were too many churches in most rural communities, leading to weak churches, insufficient financial support, and low salaries for pastors. In many cases, resident pastors could not be obtained, meaning only sporadic worship services and Sunday schools. In addition, denominational or sectarian distinctions divided country people, making the church a force for fragmentation and even conflict in the community instead of cohesion. Finally, many rural churches refused to see their responsibility to provide social services to the entire community. Many of the members of these churches remained conservative and resistant to change. ${ }^{62}$ 
The report's recommendations were threefold. First, churches must cooperate rather than compete. Churches should plan how to serve all the members of a community, superfluous churches should be abandoned, and churches should emphasize social work for all the members of the community over evangelistic work. Here the Report suggested that the rural church become a social center for its community. Next, country people should carry the work of the Y. M. C. A. to rural boys and young men. Finally, the role of the country pastor must be reconceived. He must become a community leader in the rural neighborhood, know agriculture and country life intimately, and be a permanent member of the community. ${ }^{63}$

The influence of the Country Life Movement on the farm press was obvious and direct. Henry Wallace was a member of the Country Life Commission and was therefore part of the process of writing its recommendations for the rural church. His own farm newspaper-and the others examined-delivered the same recommendations as the Commission's Report. Finally, the increased number of articles and editorials about the rural church after the appearance of the Report suggests there was a causal connection between the report and their concern.

The farm press's recommendations for the rural church aimed not only at the health of the rural church but also at the health of the countryside in general. Henry Wallace's calls for churches to become social centers and cooperate across denominational lines were tied to a process he called the "socialization of country life" and the "regeneration of life in the open country." This process of making a better life for farmers and their children would keep them living in the country. ${ }^{64}$ These recommendations were echoed in the other three farm newspapers examined. For these reasons, it is clear that the Country Life Movement directly influenced Midwestern farm newspapers' advice for the rural church. The Midwestern farm press communicated these themes from the Country Life Movement to rural Midwesterners. ${ }^{65}$

The Social Gospel had a more indirect influence on farm newspapers' recommendations for the rural church. The Social Gospel was an informal and loosely organized movement of urban Protestant pastors and lay leaders who shared a similar outlook on religion and ministry. ${ }^{66}$ Their primary emphasis was on extending salvation to embrace the larger society, rather than just working for the salvation of individuals. They called upon the church to be concerned for social issues, such as the plight of the industrial worker and the urban slum dweller. They argued that the church should be oriented towards the community, not individuals, and that it should serve its entire community. Some urban churches in the Northeast and Midwest became "institutional churches" that provided their communities with athletic 
events, vocational classes, circulating libraries, evening entertainments, and other programs. Finally, social gospel leaders called for interdenominational cooperation on social issues, downplaying doctrines that divided churches and stressing common beliefs. ${ }^{67}$

Several scholars have noted the similarities between the Social Gospel's prescriptions for urban churches and the Country Life Movement's recommendations for rural churches. Merwin Swanson asserted that Country Life leaders' concern for community centered churches demonstrated that they were "rural representatives of the social gospel." James Madison pointed to the Country Lifers' emphases on social action, ecumenicity, and liberal doctrine as evidence that their ideas were molded by the Social Gospel. Unfortunately, neither Swanson nor Madison provides specific evidence of a causal connection between the Social Gospel and the Country Life Movement. ${ }^{68}$

I have identified only one direct connection between the Social Gospel and the recommendations for the rural church in Midwestern farm newspapers: Henry Wallace's anecdote about the tornado that destroyed two of three church buildings in a community. The storm occurred on June 16, 1912, in Dublin, Ohio, a suburb of Columbus. There Washington Gladden, a Social Gospel leader and the pastor of a large institutional church in Columbus, was instrumental in persuading the Presbyterian, Methodist, and Christian Churches (the Christian Church building was the one left standing) to federate. Later, they actually merged to become the Dublin Community Church. ${ }^{69}$ In this article, a major figure in the Social Gospel, Washington Gladden, appeared in the Midwestern farm newspaper in spirit, if not in name.

Notwithstanding the lack of direct connections, similarities between the farm newspapers' advice for the rural church and the Social Gospel's program for the urban church are suggestive. These similarities are mainly to the Social Gospel as it was institutionalized within denominations, not more radical variants of Social Christianity (or Christian Socialism) such as those of William Dwight Porter Bliss or George D. Herron. ${ }^{70}$ The Midwestern farm newspaper's description of religion in rural areas focused on churches that assumed social roles in their neighborhoods and cooperation between churches of different denominations. While they seldom mentioned urban institutional churches or Social Gospel leaders, their vision for the church closely approximated that of the Social Gospel.

\section{RURAL MIDWESTERNERS' RESPONSE}

Lucy Van Voorhis White shared some of the concerns of farm newspaper editors and reporters. She wrote to her brother Frank, a pastor of a Disciples of Christ church, in February 1910: 
I quite agree with you that sectarianism is the sin of the age. . . I read an address the other day by the Methodist Bishop of Brooklyn before an audience met to discuss federation. He boldly advocated Union not Federation there was a lot of obscene talk about predistination [sic] and free grace, but after all it was good stuff.

White agreed farm newspaper writers that doctrine was less important than Christian unity. In fact, in this and in several other letters, White went beyond farm newspapers' advocacy of federation to support the union of Protestant churches. She was enthusiastic about the prospects of such a union. ${ }^{71}$

Overall, did the readership of farm newspapers share this vision of the country church? Did rural Midwesterners think that the church should primarily be a social center and that denominational differences were unimportant? I will use letters to the editor and social histories of rural America to give the contours of reader response. I will discuss positive responses first.

Eighteen letters in Wallaces' Farmer between 1910 and 1916 addressed the activities of the rural church. Fifteen endorsed the paper's program; three opposed it. Of the writers in sympathy with the paper's views on the rural church, all but one specifically supported the idea of the rural church as social center. Several gave descriptions of successful programs in their own churches. Others called for the church to sponsor community events and resources, such as youth activities, farmer's groups, holiday celebrations, corn contests, community Sunday Schools, and picnics. Thus, this recommendation received resounding support from the readers whose letters were published in the newspaper. ${ }^{72}$

Only a few of these letters mentioned the second of the farm newspaper's recommendations: that churches of different denominations should cooperate or federate. In contrast to the support given to the church as a social center, however, none of the writers gave cooperation a wholehearted endorsement. One letter complained about those who believe that they should only work or support the church of their own denomination, calling the idea "extremely narrow minded."73 Another simply noted that while their "Country Church Community Congress" was held at the Presbyterian Church, it was supported financially by a "patriotic Irish Roman Catholic."74 A third had an ambivalent tone. The author told the story of his local church, which had offered to accept people from other denominations as members. At the same time, it had also kept some denominational characteristics. Therefore while attendance had increased, membership had not, and non-members had no say in how the church was run. Although this writer sympathized with the idea of denominational cooperation, he also identified real problems with its implementation in a rural community. ${ }^{75}$ 
Only two of the letters to Wallaces' Farmer mentioned the third theme of the paper's recommendations, those concerning a new role for the rural pastor. Since the authors of both of those letters were pastors, it appears that the general readership of the paper-Midwestern farmers-was not much concerned about the pastor's role as a community leader. ${ }^{76}$

Letters to the Prairie Farmer were generally similar to those in Wallaces' Farmer. Of the letters I found between 1909 and 1916, most were supportive of the paper's recommendations. The favorable letters supported the idea of the church as a social center. None of them mentioned the recommendations concerning federation or the role of the rural pastor. ${ }^{77}$ In 1919 , a call from the editor for letters dealing with "the rural church problem" brought nine responses. Nearly all supported the idea of the church as a social center. Several complained about denominationalism among rural churches, but only one gave a whole-hearted endorsement of church federation. Like the letters printed in Wallaces' Farmer, the correspondence that appeared in the Prairie Farmer supported social activities much more than church cooperation. The letters printed by the Missouri Ruralist followed the same pattern. Of four letters addressing the rural church problem, three supported social activities and only one endorsed interdenominational cooperation. ${ }^{78}$

Letters published in the Iowa Homestead were slightly different than those that appeared in the other three papers. All of the letters to the Homestead that addressed the rural church were supportive of the paper's recommendations. Three women wrote letters to the editor of the Home Department advocating the use of the rural church as a social center. ${ }^{79}$ None of them urged denominational cooperation, and one even struck a cautious tone in her support:

I advocate the church or the district school as a center of the social movements of the neighborhood. [Usually this would be the school, but] in communities where the population holds the same religious view, the church might be the center of social activity, a center from which should radiate diversion and culture. ${ }^{80}$

She felt that the church would be a suitable social center only in areas that already had some kind of religious unity.

Several letters supported the Homestead's view of the pastor's role. In 1915 , George S. Banta praised the leadership of a pastor mentioned in an earlier feature:

That man, C. R. Green, of Ravenwood, Mo., whose work was described in The Homestead of December 31st, is the kind of a man we need in the country today. I don't know what Mr. Green draws as a salary, but I 
want to say that I will warrant that the community that has him would scarcely be willing to concede that his worth can be measured in dollars and cents. ${ }^{81}$

An unnamed writer in 1911 also supported the idea of a pastor as a community leader: "The country preacher capable of general leadership is of incalculable value. ... His influence affects society and politics." 82 Since the rural pastor's community role was stressed more by the Homestead than by Wallaces' Farmer, it is not surprising that letters in support of this proposition were found in the former but not in the latter.

However the same writer also made comments that were decidedly hostile towards the farm paper's recommendation of church federation. For instance, he asserted that the pastor must provide leadership in both religious matters as well as community activities:

If he is a Methodist he should stand for the Episcopacy for all it is worth in order to remain consistent. If his denomination is of the more democratic form ... then he must talk about it some and train his people in every election so that their example will be good in politics. Preachers should not take solemn vows to stand on a given platform and then treat it as a matter of no consequence, allowing things to run in a slipshod way. ${ }^{83}$

In contrast to farm newspaper editors who described denominational differences as matters of no consequence, this correspondent saw them as very important. He argued that country pastors should stick by their denominational distinctions both to be consistent and as a matter of keeping their vows. $\mathrm{He}$ supported a pastor's leadership in the community while also stating the importance of denominational differences.

These letters suggest that the readers of Midwestern farm newspapers were much more receptive to the first theme in the papers' recommendations, the rural church as a social center, than the second theme, interdenominational cooperation. There was less interest generally in papers' advice concerning rural pastors' roles. Perhaps the support for social activities was due to the rural church's customary role as a social center for its congregation. There was little support and no enthusiasm for the farm press's program of church consolidation.

The letters that were hostile to the farm newspapers' program are also instructive. Several letters opposing the editor's views were printed in Wallaces' Farmer. One letter from an anonymous reader opposed the paper's calls for the church building to be used as a social center. In a practice common in Midwestern farm newspapers, the paper identified the reader only as 
"a correspondent" and excerpted the letter so that Wallace could respond to its argument. Citing Christ's cleansing of the temple, this correspondent argued that God meant the church to be a place for preaching and prayer, not secular speeches and entertainments. Another writer opposed the paper's calls for church cooperation, noting that federated churches "lost their individuality as units of vigor and usefulness in the scheme of salvation." 84

A third letter, from a pastor in Missouri, took exception to both social activities and interdenominational cooperation. He asserted that the purpose of the church was not recreation. Instead, its mission was the "serious" mission of its founder: "to seek and to save." He also argued that the paper's condemnation of "denominational walls" created a church without convictions or ideas. "The farmer and his family ... need the church for which Christ died, and for which millions of his disciples have died-the church of some good and honest and scriptural convictions." 85 This country pastor disagreed vehemently with two of the three tenets of Wallaces' Farmer's program for the rural church.

The Prairie Farmer also printed letters that opposed much of the farm newspapers' program for the rural church. C. I. Hay, a pastor in Knox County Missouri, agreed with the paper's assessment of the problem: pastors were not paid enough, there were too many churches in the country, and many farmers were not interested in religion. Then he asserted that much of what writers gave as the solution for the problem was unprofitable. He argued that M. B. McNutt's church was useless as a model, since McNutt was young and inexperienced when he went there and succeeded mainly through good fortune and perseverance. He further argued that social activities were less important than the religious message of the church:

I do not believe corn in the pulpit, oats in the choir loft or any such tomfollery [sic] will ever reach, convert or draw a poor lost soul to God.... I believe that the farmer is like any other human being God ever created, and that he wants a message of love, sin, righteousness and the judgment preached to him, and I further believe he is interested in something besides clover fields, haystacks, etc.

In addition, he identified the liberal tendencies of much of the program for church federation and cooperation:

They are trying to materialize the message and leave out the spiritual entirely. ... They would make us believe that we are not living in a day when there is a personal devil, sin, etc. They scan the teaching of Jesus and pick out the bouquets and before long they will take "Higher Criticism" and "New Thought" in the field, and leave out all Jesus ever said on any occasion. 
In these ways, he argued that the farm newspapers' program for the rural church interfered with what he saw as vital to its mission: the preaching of the gospel. The gospel was a conservative message of sin and salvation, not a liberal mission of community programs. ${ }^{86}$

These letters demonstrate that at least some of the readership did not share the Midwestern farm newspaper's vision for the rural church. Social history research also suggests that farmers did not embrace farm newspapers' recommendations. Several historians assert that farmers actively resisted much of the Country Life program. ${ }^{87}$ Others have emphasized selective adaptation, asserting that country people implemented reforms and innovations that fit in with traditional ways of life and rejected those that did not. ${ }^{88}$ These letters to the editor reveal some resistance but more selective adaptation. Some writers opposed the program in its entirety. Many writers were receptive to the paper's vision of the church as a social center, but they had varying levels of acceptance of denominational cooperation and the downplaying of doctrinal differences. They did not see these processes as connected as Henry Wallace and the other editors did.

Other historians have specifically investigated the impact of Social Gospel and Country Life ideas on the rural church. It is difficult to say what percentage of rural churches became social centers for their communities, but scholars suggest that many had not become community centers by 1920 , or even by 1950 . Since Reformers continued to publish the same advice for fifty years, it appears that relatively few churches had responded. ${ }^{89}$ The lack of interchurch cooperation is more easily tracked. According to the 1926 Religious Census, there were only 301 federated churches out of over 150,000 churches in rural areas. ${ }^{90}$ Most rural churchgoers simply did not have the same assumptions as farm newspaper editors, Country Life leaders, or the promoters of the Social Gospel. Many were concerned about doctrine and creed and viewed the rural congregation itself as a community. Farm newspapers' advice was accepted partially or simply disregarded.

In the late nineteenth and early twentieth centuries, the rural church in the Midwest was in transition. Conflicting visions of the nature and mission of the country church appeared in the Midwestern farm press. Farm newspapers' recommendations were threefold: rural churches should become community centers, rival denominational churches should cooperate, and rural pastors should become leaders in their community. This advice was part of the Country Life Movement's drive to revitalize life in the countryside. It also appears that the Social Gospel influenced farm papers' recommendations for the rural church. Because the editors and publishers of Midwestern farm newspapers had left farms for cities, they came into contact with such urban 
reform ideas. Editors did not merely communicate what country people were already doing; they called for radical changes to one of the countryside's most important institutions.

Evidence from farm newspapers themselves and from social histories suggests that rural Midwesterners selectively adapted these recommendations. Country people embraced a social role for the church, which in many areas had been part its mission for many years. They rejected interdenominational cooperation. They were relatively unconcerned about a new role for pastors. Major changes did eventually come to the rural church, but they came as a response to even greater population pressures, especially after the Second World War. Change did not come as a result of the recommendations that Country Life leaders, Social Gospelers, or farm newspaper writers made during the first decades of the twentieth century. 
Page Intentionally Left Blank 


\section{Chapter Six}

\section{"The School House at the Crossroads":}

\section{The Rural School and the Midwestern Farm Press}

The time has come when the progressive farmer must turn his attention to the school house at the crossroads with the thought of securing better schools in the country for country children.

- Jessie Field, Superintendent, Page County, Iowa Schools ${ }^{1}$

One-room rural schools, as much as rural churches, were vital to Midwestern rural society in the late nineteenth and early twentieth centuries. There were more one-room schoolhouses than church buildings in the country. At the turn of the twentieth century, lowa had over twelve thousand rural schoolhouses, and Illinois and Missouri each had close to ten thousand. All told, the Middle West had over ninety thousand schoolhouses in 1918, "almost as many as in the rest of the nation combined." Nearly every rural neighborhood had its own one-room school. ${ }^{2}$

In the early twentieth century Midwest, teaching methods were much the same as they had been fifty years earlier. Children learned reading, writing, arithmetic, spelling, and orthography. They normally memorized their lessons and recited them for the teacher. In most one-room schools, one teacher taught these subjects to all eight grades. Pupils might be as young as six years old or as old as twenty. Generations of farmers, town leaders, and even national figures had attended such one-room schoolhouses for their common school education. ${ }^{3}$

Midwestern schools were controlled locally. In Iowa, each local district elected its own board of school directors that maintained the building, 
employed the teacher, selected text books, and levied taxes. Only men could vote in these yearly elections, but women could serve on the board. County school superintendents were elected to two-year terms in partisan elections. They examined and certified teachers and visited rural schools. County superintendents typically had much less to do with the urban schools in their county, which were often headed by their own superintendents who had more education and made higher salaries. The state Superintendent of Public Instruction was a figurehead, for the position had no real authority over county superintendents or over any schools. The situation was similar in Illinois and Missouri. ${ }^{4}$

By the late nineteenth century, the rural schoolteacher was usually a young woman, and she was paid less than the men who had occupied the position earlier in the century. In the nineteenth century, she was often an eighth grade graduate who was not much older than the students. By the early twentieth century, many Midwestern towns had established high schools, so more teachers in rural schools had a high school diploma. Only a small percentage of rural schoolteachers had a college degree. For example, in Illinois in 1913, about twelve percent of all teachers were college or normal school graduates and about twenty-one percent had attended normal school for some time. Almost twenty-five percent did not have any high school education. ${ }^{5}$ The most common source of post-high school instruction for teachers was a yearly "Teachers' Institute" held during the summer in county seats across the Midwest. Sponsored by State Departments of Public Instruction and staffed by State Teachers' Colleges, this week-long event provided some instruction in teaching methods and classroom management. A rural schoolteacher received a small salary and many times worked at a rural school only until she obtained a job at a town school or she married. For all of these reasons, the quality of instruction was extremely variable. ${ }^{6}$

While some school buildings in the open country were pleasant places in which to study, others offered a disagreeable learning environment. Most one-room schoolhouses were small. Many were poorly heated and inadequately ventilated. Often, the main light source was the windows, meaning that for those far from a window-or for all students on a rainy day-reading could be difficult. Most lacked indoor plumbing or a room in which to hang up coats. Some rural schoolhouses were in bad repair. ${ }^{7}$

In addition to these physical obstacles to education, rural schools faced demographic stresses in the early years of the twentieth century. The beginnings of outmigration from rural areas led to falling enrollments in many rural districts. In Iowa in 1910, just over three thousand one-room country schoolsalmost one fourth of the total number-had fewer than ten pupils enrolled. Ten 
schools had only one pupil. ${ }^{8}$ It was expensive for a rural community to hire a teacher for fewer than ten students. Reformers increasingly saw the rural school, like the rural church, as experiencing a crisis. ${ }^{9}$

Farm newspapers provided a forum for the discussion of issues surrounding rural education. They published criticism of and advice for the rural school. They also printed letters to the editor that responded to those critiques and recommendations. Between 1895 and 1920, the Midwestern farm press depicted the one-room schoolhouse, which often literally stood at the crossroads of a community, as figuratively standing at a crossroads. For farm editors and country people, its future was unclear. Reformers painted a disastrous future if their recommendations were not put into practice. Like recommendations for the rural church, rural Midwesterners did not accept these reforms wholesale; they resisted some and selectively adapted others.

This chapter will examine the coverage the Midwestern farm press gave to issues surrounding rural education. First, it will describe educational reformers' plans for the rural school and the political and legislative results of their efforts. It will then assess farm newspapers' recommendations for the rural school, considering how these recommendations were related to those made by reformers. Next, it will address how rural Midwesterners responded to farm newspapers' advice. Finally, it will evaluate previous explanations for rural resistance to rural school consolidation in light of this evidence. Historians who have examined the subject agree that most country people opposed school consolidation, but they disagree about the reasons for their opposition. Farm newspapers' coverage of the rural school can tell us both about the role of the papers in turn-of-the-century educational reforms and the decisions of country people faced with those reforms.

\section{REFORMERS AND THE RURAL SCHOOL}

Beginning in the 1890s and continuing through the 1920s, a group of determined educational reformers worked to recreate American public education. Led by John Dewey and other educational theorists, they were inspired by the educational innovations of Germany, especially its large technical schools that trained children for success in the new industrial world. Efficiency became highly valued among educational leaders in state governments, universities, and teacher's colleges. Reformers turned to urban schools first, creating high schools with hierarchical management in the late nineteenth century. They then turned to the countryside. Here Denmark was used as a model, for public schools there taught agriculture in the classroom. 
Most Danish rural schools had also been consolidated into graded schools with high schools. In the Midwest, state Superintendents of Public Instruction, educators at normal schools, and some county school superintendents assailed the one-room rural school for being inefficient and out of step with the times. They recommended agricultural education and rural school consolidation. ${ }^{10}$

"Agricultural Education" consisted of several elements. At its most general, it was defined as the teaching of agriculture in the classroom. "Nature study" and elementary biology were recommended for lower grades. In later grades-and especially in high school-the concepts and methods of scientific agriculture were to be taught. Reformers thought that only boys would be interested in agriculture and that this instruction would only be useful for them. Therefore, they usually coupled agricultural instruction with domestic science instruction for girls. Reformers also promoted "manual training," later known as "wood shop." Agriculture was central to all descriptions of improved curriculum, however, while domestic science and manual training often appeared as add-ons to the teaching of agriculture. ${ }^{11}$

Rural school consolidation, however, was more important to many educational reformers. Consolidation involved the creation of a large school district out of four or five rural school districts served by one-room schools. The new district school board would then erect a multi-room school building in a central location, and wagons would bring in children from as far out as seven or eight miles. Consolidated schools employed several teachers, divided students into grades, and often provided a high school education. Reformers saw consolidation as a way to achieve efficiency in supervision of schools, to establish their control over country schools, and to equalize educational opportunity in rural and urban areas. ${ }^{12}$

In order to stimulate these changes, leaders of the Country Life movement added a note of urgency to the debate over rural school reform. The rural school was an important element of the Country Life Commission's program for the improvement of rural social life. In President Roosevelt's "Special Message" to Congress that accompanied the Report of the Country Life Commission, he called rural school reform as one of the country's three "great general and immediate needs." Roosevelt called for "a new kind of schools [sic] in the country, which shall teach the children as much outdoors as indoors and perhaps more, so that they will prepare for country life, and not as at present, mainly for life in town." 13 The report itself echoed these sentiments about a rural education "adapted to the real needs of the farming people" that would "educate pupils in terms of daily life." It asserted 
that "the schools are held to be largely responsible for ineffective farming, lack of ideals, and the drift to town." The Commission recommended that rural schools teach agriculture and domestic science, that the federal government appropriate funds to support these subjects, and that the Bureau of Education be enlarged in order to oversee the effort. ${ }^{14}$

Individual Country Life leaders also charged that one-room schools contributed to the migration from rural areas to cities. Some claimed that the deficiencies of country schools drove farmers to rent their land and move to a town or city to obtain a better education for their children. Others said that schools educated farmers' children away from the farm by stressing skills necessary for success in town jobs. Reformers argued that education in agriculture and domestic science would prepare farm children for life in the country, not for work in towns or cities. Consolidation provided educational advantages that would keep farm families in the country. ${ }^{15}$

Because schools were controlled locally, state legislative efforts were necessarily piecemeal and gradual. By 1920, however, Midwestern state legislatures had expanded the power of the state educational bureaucracy and were pushing local school boards to implement portions of educational reformers' program. By 1911, all the Midwestern states had removed teacher's examinations for certification from county superintendents and placed them in the state superintendent's office. Iowa had put all teacher certification in the hands of the state superintendent. By the end of the decade, Iowa and Missouri had also created and employed a state rural school visitor who inspected rural schools just as the county superintendents did. State laws also made consolidation progressively more important and easier to accomplish. By 1920, all three states had passed legislation stipulating a procedure for consolidating rural schools. Moreover, the Iowa legislature passed a law in 1913 that required the teaching of domestic science and agriculture in all public schools and required teachers to pass examinations in the two subjects before certification. When the law went into effect in 1915, it encouraged consolidation because consolidated schools could more easily teach the subjects. State political battles over school consolidation are impossible to summarize in a short space. In general, rural people opposed most consolidation laws. State legislatures passed them in response to lobbying by State Departments of Public Instruction, Teachers' College professors, Country Life leaders, and other progressive reformers. ${ }^{16}$

In the late nineteenth and early twentieth centuries, farm newspaper editors in the Midwest discovered the rural school crisis. Editorials, articles, and features generally supported agricultural education and school 
consolidation. The coverage provided by Midwestern farm newspapers reveals the influence of urban educational reformers and Country Life leaders.

\section{FARM PAPERS ADDRESS THE RURAL SCHOOL PROBLEM}

The four newspapers studied devoted many more articles and editorials to the rural school than they did to the rural church. Midwestern farm newspapers addressed agricultural education and consolidation at length. They also dealt with several other issues, including how to improve the oneroom school, issues of teacher quality and remuneration, and alternatives to consolidation.

\section{Agricultural Education}

The Midwestern farm press enthusiastically supported the teaching of agriculture in rural schools. Farm newspapers recommended "nature study" in lower grades and the full-scale study of agriculture in the high school. Their support began early in the period and continued unabated until about 1916. Articles and editorials identified obstacles to agricultural education and provided suggestions on how to teach agriculture. "How We Did it Right" features trumpeted individual counties and schools who taught agriculture successfully. The farm press supported agricultural education mainly because authors believed that it would keep farm children in the country.

All four newspapers printed articles and editorials in support of agricultural education early in the period. In 1896, an editorial in the Iowa Homestead asserted that "A great deal could be done in behalf of intelligent agriculture, if the elements of the art were taught in rural schools. The most important thing, too, for the present is to make a beginning." 17 Henry Wallace wrote in Wallaces' Farmer that "there should be a line of teaching in the public schools that will inculcate a love of farm life, as well as a knowledge of the thousands of valuable facts which he [the farm boy] should comprehend." 18 An 1899 editorial in the Prairie Farmer urged the passage of an Illinois bill that required the teaching of agriculture in ungraded country schools. Finally, the Ruralist in its first year of publication also endorsed the teaching of agriculture in rural schools. ${ }^{19}$

Writers admitted that there were obstacles to agricultural education. Few textbooks for public school agriculture existed, and few teachers were qualified to teach the subject. Still, farm paper editors and authors asserted that a start must be made. They called for normal schools to train teachers 
to teach agriculture and publicized those schools, such as the Iowa State Agricultural College, the University of Missouri, and the Illinois Agricultural College that had developed such courses of study. ${ }^{20}$ Authors and editors looked forward to the day when agriculture would be a fixture in rural schools. ${ }^{21}$

In addition to calls for rural schools to teach agriculture, farm papers also provided instructions for teaching such classes. One way was to add a course in agriculture to the curriculum of the one-room country school or to the high school. Farm papers suggested that these classes be taught in a hands-on manner. Teachers might ask students to bring in some of their father's seed corn to be judged by the class. Land near the school could be set aside for garden plots or a nursery. Perhaps the school could even buy some animals for students to raise. ${ }^{22}$ In the 1910s, articles laid out complete courses of study in agriculture. One feature in the Iowa Homestead described a four-year course in which students studied soils, physiography, general science, botany, plant propagation, horticulture, forestry, field and forage crops, dairying, animal husbandry, agricultural chemistry, farm mechanics, and farm management. ${ }^{23}$

Another recommendation was that teachers integrate agriculture and country life into the other subjects they taught. Teachers should give agricultural examples as problems in arithmetic class and country life topics as the subjects for essays. In 1911, the Prairie Farmer went so far as to create an "Educational Department." The department discussed issues in education in general, the rural school, and agricultural education. An almost weekly feature of the department consisted of arithmetic problems and composition topics on agricultural subjects. The answers to the math problems were given the following week. ${ }^{24}$

Finally, farm papers also provided descriptions of successful efforts to teach agriculture. The Iowa Homestead trumpeted the success of several county superintendents in Iowa: Clara Wright of Adams County, Jessie Field of Page County, and O. H. Benson of Wright County. Wright and Field encouraged the principals and teachers in their counties to set up agriculture and domestic science clubs to interest children in better farm and housework methods. They also sponsored countywide contests and fairs to get children involved in corn selection and the care of animals. Benson required the teaching of agriculture in all of the 140 schools in his county. He supported it by sponsoring picnics, fairs, and other social events to showcase the abilities of the children. ${ }^{25}$ Wallaces' Farmer featured Jessie Field's contests and clubs, presented the course of agricultural study at the Page County's Coin School, and profiled Mary Fennington's rural school in Wright County, 
where agriculture was integrated into all subjects. ${ }^{26}$ The Prairie Farmer also mentioned Benson's efforts, but it focused more on those of O. J. Kern, County Superintendent of Winnebago County, Illinois. Kern established agricultural education in every school in the county. ${ }^{27}$ The Ruralist followed the development of agricultural and domestic science classes of Marie Turner Harvey at the Porter school near Kirksville, Missouri. Harvey gained national attention when Evelyn Dewey, the daughter of John Dewey, wrote a book about her school. ${ }^{28}$

Articles celebrating the successes of these progressive educators demonstrate the influence of early twentieth century educational reformers on farm newspapers' coverage of the rural school. While relatively few county superintendents were promoting agricultural education, farm papers consistently advertised the victories of these educators.

Midwestern farm newspaper editors and writers also promoted agricultural education for the same reasons as Country Life leaders. The reason most often given was that they believed it would help to keep farm children on the farm. The author of a 1903 Homestead feature asserted that "if our children had a more comprehensive knowledge of farm affairs they would be much more apt to choose agriculture as an occupation." 29 Henry Wallace asserted that farm children should be taught "a love of agriculture, that can be done only by teaching in the spirit of the farm and in harmony with farm life." 30 The similarity between country life arguments and farm newspaper coverage-and Henry Wallace's membership on the Country Life Commission-indicates that the Country Life movement directly influenced farm newspapers' coverage of the rural school. ${ }^{31}$

After 1916, agitation for agricultural education decreased markedly across all four farm newspapers. Coverage of agricultural education almost disappeared from the pages of the Homestead. The only mention of the practice was in 1920 in a "Publisher's Views" piece by James Pierce. Wallaces' Farmer printed only two additional editorials on the topic after 1916. The Missouri Ruralist did not mention it again until 1919. That year and the next, the paper ran a number of "How We Did it Right" stories about Missouri schools. ${ }^{32}$ The issue was not addressed at all in the Prairie Farmer after 1916. Agricultural education had become mandatory in Iowa, so there was much less reason for the Iowa papers to champion the reform. In addition, the issue of rural school consolidation received more coverage during these years. It is likely that articles and editorials on rural school consolidation pushed considerations of agricultural education off the pages of Midwestern farm newspapers. 


\section{Rural School Consolidation}

While the teaching of agriculture in rural schools was covered in Midwestern farm newspapers as early as 1895 , the consolidation of rural schools appeared several years later. Consolidation, however, provoked more discussion and to remained in the news longer than agricultural education. Consolidation was first discussed in Wallaces' Farmer in 1898. It first appeared in the Homestead in a special eight-page Supplement published with the December 26, 1901 issue. The issue did not appear in the Ruralist or Prairie Farmer until 1904 and 1905 respectively. But after these dates, all four newspapers provided steady coverage. ${ }^{33}$

There was also less unanimity among the editors of the four newspapers studied on the topic of rural school consolidation. The editors of the Iowa Homestead, Prairie Farmer, and Missouri Ruralist gave consistent support to consolidation as a way to improve rural education. Henry Wallace only slowly came to promote consolidation.

Editorials and articles in the Homestead invariably supported rural school consolidation. They touted consolidated schools ability to give farmers' children the advantages of a town education, arguing that better educational opportunities would stop farmers from moving to town. Authors asserted that division into grades allowed teachers to have fewer recitations and therefore to teach more subjects than at a school where one teacher taught all grades. School consolidation also made it possible to hire better teachers and provide more educational choices. Consolidated schools were cheaper and more efficient, and such schools made education in agriculture, domestic science, and manual training possible. The paper was lavish in its praise. ${ }^{34}$

Proponents of consolidation writing for the Homestead also attacked the one-room school as a way of making their case. An author of a 1913 feature argued "The one-room, one-teacher school is the menace of rural education." The article castigated one-room schoolhouses for inefficiency, irregular attendance, wasteful and unscientific management, and poor equipment and furnishings. It argued that consolidation would pull the country school "out of the valley of desolate despair in which it has been allowed to remain all too long." 35 Another article asserted "the present system of operating country schools is wasteful, both financially and educationally." Its author argued that consolidated schools provided children with more incentive to work by cultivating competition and enthusiasm. They provided better teachers, better grading, and better supervision, all for less money. ${ }^{36}$ 
Articles in the Missouri Ruralist and the Prairie Farmer were similarly excited about consolidation. One feature-writer for the Ruralist effused:

Our American citizens are progressive and the schools of today will pass away just as the old stage coach gave away [sic] to the locomotive and as the locomotive must give away [sic] to electricity. So our old rural school building will pass away and up-to-date buildings with modern equipments [sic] will take their place. ${ }^{37}$

The Ruralist's editor, John F. Case, consistently supported consolidation, even though he recognized that many consolidation elections became bitter fights. In fact, the northwestern Missouri district where he lived during the summer had soundly defeated a consolidation attempt in the early 1910s. Nevertheless, he confidently asserted "we need consolidated schools in Missouri for consolidation means solution of the rural school problem."38 The Prairie Farmer printed a large number of "How We Did it Right" features on successful consolidated schools. ${ }^{39}$

In contrast to these enthusiastic treatments, Wallaces' Farmer reported on school consolidation from 1898 to 1908 before endorsing the idea. The paper's coverage of rural school consolidation and Henry Wallace's editorials both show that Wallace was a reluctant convert to the benefits of consolidation. In the 1890 s, Wallace was distinctly non-committal on the issue of school consolidation. He saw it as a result of the crisis that rural society faced, but he was unwilling to take a stand for or against school consolidation. ${ }^{40}$ In 1900 the paper ran a glowing description of the Buffalo Center consolidated school in Winnebago County, Iowa, written by its principal. Wallace accompanied the report with a disclaimer, however, asserting that "we are not convinced that this is the best plan for all the districts, or the majority of the districts of the state. In our opinion, it is a plan that is worthy of the farmers' study. Something will have to be done with our rural schools." 41 In a 1901 editorial, Wallace hoped that population loss in the country might be reversed and make the issue moot:

It is to be hoped that rural delivery, farm telephones, good roads, circulating libraries, together with improved methods of farming will check the movement of the farmer to town and increase the attendance and the efficiency of the rural public schools. If the trend does not set in this direction pretty soon, the conditions will be a great deal worse than they are now. ${ }^{42}$

Thus, while Wallace gave dire warnings of the future of the rural school, he did not endorse consolidation as the solution to its problems. 
As the new century progressed, Wallace began to give a less guarded endorsement to consolidation. One editorial argued that many districts might have to consolidate to deal with a teacher shortage. Another praised an Illinois law that allowed schools to use tax money to pay for transportation to consolidated schools. In 1907 Wallace gave consolidation guarded support: "We believe that the merging of weak schools will help in many cases. In many other cases the consolidation of the township will help." 43 The paper ran articles on consolidated schools in Illinois and Indiana. Still, even in these editorials, Wallace withheld complete endorsement, saying that consolidation was still too new to say that it would definitely stop country people from moving to town. ${ }^{44}$

Late in 1908 and early in 1909, however, Wallaces' Farmer printed several editorials that were much more supportive of consolidation. Their publication coincided with the time that Henry Wallace served on the Country Life Commission. It appears that his son Henry C. Wallace wrote editorials on the social issues his father normally covered while the elder Wallace traveled with the Commission. Henry C., the journalist, had a distinct style from different from his father, the preacher. He used less Biblical imagery, and his prose was less polished. Henry C. seems to have been much more optimistic about school consolidation. In December 1908 he argued that consolidation was the future of education in lowa, and he defended his position when challenged by "a northern Iowa correspondent" in early 1909.45

Henry Wallace, when back in the editor's chair, finally came to substantially support consolidation in 1909. Perhaps the change reflects the influence of his son; perhaps it resulted from discussion with interested parties. While the Country Life Commission's Report did not mention consolidation, some of its members were supporters of the reform. Whatever the reason, in an editorial printed August 20, Wallace published the most forthright statement in favor of consolidation he had yet made:

The whole evil [of outmigration from rural areas] could be remedied with very great economy and a vast amount of additional comfort, to say nothing of the benefit to the whole community, if farmers could see that the proper thing for them to do is to establish a graded school not in the town but in the township ... where the children receive a better education for farmers' children than it is possible for the high school in town to give them. This, of course, mcans the centralized school. ${ }^{46}$

Here, Wallace set up a choice not between the current country school system and consolidation but rather between farmers moving to town and consolidation. To this choice, Wallace could only agree that consolidation was a better option. 
Later editorials still treated consolidation carefully, possibly because Henry Wallace realized that most of his readers did not support consolidation. He reported in one editorial that he thought that perhaps ninety percent of farmers were against consolidation. In another, he noted a "widespread prejudice in Iowa against any system of centralizing the schools." But he also gently tweaked those who opposed consolidation: "We are convinced that much of this prejudice is due to a lack of understanding of just what the centralizing of schools does." ${ }^{47}$ By 1914 , Wallace was arguing that the question was no longer whether schools should be consolidated but where the consolidated school should be located. After Henry Wallace's death in 1916, the paper became even more openly supportive of consolidation, both in editorials and in a number of "How We Did it Right" articles on successful consolidated schools. Thus, all of the farm newspapers studied eventually provided solid support for rural school consolidation. ${ }^{48}$

The Midwestern farm press provided many arguments for consolidation. Most were summarized in a 1904 Ruralist article by the State Superintendent of Public Schools in Missouri. He argued that school consolidation secured better teachers, paid higher salaries, classified students into grades more reliably; provided for better supervision by teachers; made possible additional classes such as music and agriculture; and enabled better buildings, equipment, and libraries. In addition, larger classes stimulated students to greater effort due to competition: "There is a force in numbers that can not be found in a small class or school. A class of ten is better than a class of two." The consolidated school building could also be used as a social center for the community it served. Finally, transportation by wagon discouraged "playing hooky" and made for more regular attendance. Consolidated schools had lower per capita cost than poorly-attended rural schools. ${ }^{49}$ While few pieces cataloged all the possible benefits like this one did, most included one or more of these arguments for consolidated schools. The arguments for rural school consolidation did not change significantly between the late 1890s and 1920 .

Few articles and editorials addressed the problems associated with consolidated schools. The most extensive consideration of objections is a 1906 Homestead article. The author admitted several objections, but he then responded to them all quickly. While the transportation of pupils in wagons from the far corners of districts might pose problems, the author argued that bad roads could be made better and that competent and safe drivers could be found. While some asserted the consolidated school cost more money, the author replied that this was true only while the school building was being paid off. After that, a consolidated school was less expensive. To those who complained that it eliminated the one-room schoolhouse as a social center, the 
author responded that the telephone and better roads had made the neighborhood almost as big as a township already. A consolidated schoolhouse would better serve this larger community. Other articles in Wallaces' Farmer and the Prairie Farmer also mentioned these common objections to consolidation, but each provided answers to the objections and concluded in favor of the consolidated school. ${ }^{50}$

Educational reformers influenced farm newspapers' coverage of this issue, for farm papers ran articles promoting consolidation written by educational leaders. The Iowa Homestead featured articles and features by Frank Nelson, Kansas Superintendent of Public Instruction; C. P. Cary, Wisconsin Superintendent of Public Instruction; and John F. Riggs, Iowa Superintendent of Public Instruction. ${ }^{51}$ The paper also excerpted or printed speeches by Fred H. Rankin of the Illinois Agricultural College, C. R. Barnes of the University of Minnesota Extension Department, and C. F. Curtiss of the Iowa Experiment station. ${ }^{52}$ Finally, in the late 1910s, Macy Campbell, the Head of the Department of Rural Education at the Iowa State Teachers' College, wrote feature articles for both Wallaces' Farmer and the Iowa Homestead. ${ }^{53}$ All of these writers championed the consolidated school as progressive, up-to-date, and suited to agricultural conditions.

Country Life leaders' ideas about consolidation were also communicated in farm newspapers. They argued that consolidated schools would improve rural education and thereby stop the drift from rural areas to cities. As these schools provided a better education, fewer country people would move to towns or cities for educational reasons. Keeping their children in their neighborhood for school would mean that fewer of their children would be "educated away from the farm." 54 As we have seen, Midwestern farm newspapers made all of these arguments.

Rural school consolidation remained a well-covered topic even into the 1920s. After a short interruption in coverage during the First World War, editorials in the Iowa Homestead again listed the problems of the rural school and the advantages of consolidation. In Wallaces' Farmer, even the war did not decrease the number of pieces devoted to the topic. ${ }^{55}$ In their front-cover features, on their editorial pages, and in many articles printed throughout the paper, Midwestern farm newspapers enthusiastically supported rural school consolidation.

\section{Additional Issues}

Midwestern farm newspapers also offered other advice to rural schools. Editorials and articles recommended ways to improve the one-room rural school; discussed the quality and pay of teachers; counseled country people 
to use their rural school building as a social center; and advocated the county agricultural high school.

Farm newspapers saw no contradiction in giving wholehearted support to consolidation while also offering advice for how to enhance the oneroom, one-teacher rural school. The most frequent recommendations had to do with improving the schoolhouse itself. The building should have new paint on the outside, wallpaper and window shades on the inside, and trees and bushes on the grounds. ${ }^{56}$ In addition, papers enjoined farmers to visit their rural schools, to get to know their teachers, and to find out what they could do to help them teach their children. Perhaps farmers could organize a parent-teacher association. ${ }^{57}$ John F. Case and Henry Wallace were concerned that all rural Midwesterners elect good school directors and county superintendents. James Pierce asserted in a 1915 editorial that "the one room country school house will not disappear, in your day or mine." Therefore he recommended that farmers "make it as attractive and its courses of study as practical as human ingenuity can devise." 58

Another set of recommendations concerned rural schoolteachers. Many articles and editorials argued that the success of a rural school, consolidated or otherwise, depended on its teacher(s). Therefore communities should maintain high standards for their instructors. Editorials castigated farmers for offering such meager salaries that only less-qualified teachers applied. ${ }^{59}$ In addition, low salaries meant that many teachers stayed in the country only until they had enough experience to get a job teaching in a town or city school. Authors and editors presented higher salaries as the solution to teacher shortages among rural schools. Higher salaries would keep good teachers in the country-and in one district-longer. ${ }^{60}$

Some editorials and articles recommended that the rural schoolhouse be made the social center of their community. Farm newspapers more often recommended that the rural church be the social center of its neighborhood, but authors also thought that rural school buildings could serve as social centers. Farmers clubs, women's clubs, holiday social events, and other entertainments could all be held at the rural schoolhouse. Most of these referred to the neighborhood, one-room schoolhouse, but some argued that the consolidated schoolhouse would fill this role even better. ${ }^{61}$

Finally, farm newspapers also proposed an alternative to consolidation: the creation of county agricultural schools. Rural districts could keep their one-room schools, but the county would construct a building near the center of the county in which to run a high school that specialized in agriculture and domestic science. Several counties in Wisconsin had created such schools. These recommendations appeared mostly before 1916. It appears 
that after this date, rural school consolidation became the editors' reform of choice. ${ }^{62}$

These recommendations occupied much less space on the editorial and feature pages of Midwestern farm newspapers than the teaching of agriculture and rural school consolidation. It is important to note them, however, because some historians identify agricultural education and consolidation as the only improvements promoted by reformers. For example, Hal Barron describes rural school reform as consolidation of one-room country schools into graded schools, often at the township level. He does not address agricultural instruction, teacher qualifications, or any of the other solutions to the rural school problem advanced in the pages of farm newspapers. ${ }^{63}$ While vigorously promoting agricultural education and consolidation, farm newspapers also considered other methods for improving education in the country.

In general, however, on the issue of rural school reform, the Midwestern farm newspaper can be seen as a mouthpiece for Country Life leaders and educational reformers. The recommendations farm papers advanced for the rural school were in line with these groups' program. The papers even provided a forum for School Superintendents and other educational leaders to take their case straight to rural Midwesterners.

\section{RURAL MIDWESTERNERS RESPOND}

The firmness and confidence with which the Midwestern farm press made its recommendations prompts questions about the opinions of its readership. Did farmers share the assessment that one-room schools were backward and out of step with the times? Did rural Midwesterners endorse the teaching of agriculture and domestic science? Did country people agree that consolidation provided the best way to improve their children's education? Did they think that agricultural education and consolidation would keep their children from leaving the farm? Letters to the editor and the observations of social historians shed light on rural Midwesterners' responses to the farm newspapers' recommendations about agricultural education and consolidation.

\section{Agricultural Education}

Letters to the editor of Midwestern farm newspapers provide insight into rural Midwesterners' beliefs about the teaching of agriculture and domestic science in the rural school. Wallaces' Farmer published the most letters; seventeen different letters between 1903 and 1918 addressed agricultural education. Eleven letters supported the teaching of agriculture and domestic science in rural schools, and six opposed it. Those who 
supported agricultural education presented most of the same arguments given in farm newspapers. They asserted that teaching agriculture and domestic science would keep farm children in the country. Supporters also provided stories of how these subjects were included in the course of study at their local country school. ${ }^{64}$ School superintendents or teachers wrote at least three of the letters, describing successes in their schools. ${ }^{65}$

Those who opposed the teaching of these subjects in schools presented two objections. First, they argued that the purpose of school was to teach the basics, not unnecessary additional subjects such as agriculture and domestic science. One stated that "country children should go to school to study, to train the mind, to acquire information they cannot find at home."66 In addition, these correspondents believed that these subjects could be better taught at home. Ada B. F. Parsons stated that "there is a time and a place for everything, and the country school-below the ninth gradeis not the place for it [agricultural education]."67

The other farm newspapers printed similar letters, some that supported and some that opposed agricultural education. Letters to the Iowa Homestead and Ruralist applauded successful rural schools that were teaching agriculture and domestic science. ${ }^{68}$ However, these papers also published letters that opposed such education. Such correspondents agreed with Wallaces' Farmer opponents that such subjects were better taught at home. "I think that kind of teaching is money thrown at the birds," said one writer in the Homestead. ${ }^{69}$

Thus, like letters to Midwestern farm newspapers about the rural church, letters about agricultural education revealed that some rural Midwesterners were unhappy with the papers' program for agricultural education. A majority of the letters sent to Wallaces' Farmer, however, supported the teaching of agriculture and domestic science in the rural school. Letters to other papers were divided almost equally on the issue.

The work of social historians suggests that agricultural education was taught in some districts but not others. Wayne Fuller suggests that it was successful in those areas where committed teachers and superintendents convinced farmers that it would keep their children on the farm. Yet some farm families continued to believe that schools should teach basic subjects and leave agriculture, carpentry, cooking, and sewing to be taught in the home. Others desired the best academic education possible for their children because they wanted them to go on to the agricultural college or to the state university. In either case, the vast majority of country teachers continued to be unqualified to teach agriculture into the late 1910s. It appears that enforcement of Iowa's law was lax. Some enthusiastic superintendents and 
teachers succeeded in integrating agriculture and country life topics into the curriculum of their schools. Many did not. ${ }^{70}$

The teaching of agriculture and domestic science in rural schools generated fewer letters to the editor than did rural school consolidation. Articles on the consolidated school eventually drove agricultural education from the pages of Midwestern farm newspapers. It appears that letters to the editor about the teaching of agriculture in rural schools suffered the same fate. Consolidation sparked much more discussion-and conflict-in Midwestern farm newspapers.

\section{School Consolidation}

Both proponents and opponents realized that the consolidation of country schools would dramatically change a central institution of rural life. The proposal, therefore, stirred deep emotions from all sides. Farm newspapers provided a forum for rural Midwesterners to express both their support and opposition to consolidation.

The Iowa Homestead provided an opportunity for readers to voice their opinion about consolidation in 1916. In December 1915, James Pierce wrote a "Publisher's Views" piece that reviewed a speech by the Iowa State Superintendent of Public Instruction A. M. Deyoe. Apparently Deyoe had castigated farmers for their inattention to their schools. He blamed rural schools' problems on country people's unwillingness to pay more for the education of their children and their aversion to consolidation. Pierce argued that while there might be some inattentive districts, the majority of Iowa farmers were progressive and their schools were good. He asked for readers to send in their opinions on the issues raised by the Superintendent's comments. ${ }^{71}$

In response, the January 6, 1916 issue of the Homestead contained a feature titled "The Country School Problem" and subtitled "A Sheaf of Letters from Homestead Subscribers Discussing Consolidation and Country High Schools, Pro and Con, in Response to Mr. Pierce's Suggestions." It published a number of letters from readers about the problems of rural schools; most had to do with consolidation. ${ }^{72}$ In the following issues, the discussion was continued on the Homestead's "Experience Meeting" page of letters from readers. Many authors responded to earlier letters, giving names and either answering other writers' objections or agreeing with their observations. Between January and June 1916, the Homestead published twenty-four letters that specifically addressed consolidation. Six of the letters were in favor of consolidation; eighteen of the respondents opposed it.

Those who opposed consolidation wrote first and wrote most often. They mainly used four arguments in their opposition: the long rides in wagons 
required by a central school, the higher taxes necessary to support a consolidated school, the motives of town people in supporting consolidation, and the belief that their own local school was good enough. The reason most often cited for opposition was the problem of transporting children to consolidated schools. Opponents complained that the rides were too long: many children might leave home before six o'clock in the morning and not get home until six or seven o'clock at night. The wagons might also not provide sufficient protection from cold and wet weather and could be breeding grounds for germs. Wagon drivers might corrupt the character of their charges. ${ }^{73}$ As one author complained:

In going to a consolidated school the pupils are packed, like sardines in a box, in some kind of a conveyance, and taken to the central building. This conveyance, if not fumigated every morning, will harbor germs that will play havoc with the farmer's healthy children.... Besides this, the pupils learn all kinds of cuss words and smart saying [sic] which are unbecoming to a child, and soon they begin to think they know as much as or a little more than father and mother. ${ }^{74}$

Farmers vehemently opposed consolidation plans because of the transportation problem. ${ }^{75}$

Letter writers also argued that consolidation meant higher taxes. Proponents had often asserted that consolidated schools were cheaper to operate than several one-room schools. It was clear by 1910 that this was not the case. While fewer teachers might be needed in a consolidated school, a janitor, drivers for the wagons, and often a principal had to be hired. In addition, consolidated school teachers often earned higher wages. Finally, the cost of building a new, larger school building usually required a bond issue. As a result of all these increased expenses, district officials often had to raise property taxes. While the consolidated school might have been more efficient, it was not less expensive. Correspondents to the Homestead asserted that proponents of consolidation were often those who owned little property to be taxed. They claimed that consolidation raised their taxes too high. ${ }^{76}$

Opponents of consolidation also believed that town people sought consolidation to improve their schools at the expense of country people. The Iowa Code allowed for consolidation of rural districts with a town school, but the law required that separate elections be held inside the town limits and outside of them and with a majority in both elections necessary for consolidation to pass. Still, many rural Midwesterners chose to consolidate with a town, often to preempt consolidations with rival towns they saw as not to 
their advantage. One writer to the Homestead charged that town supporters paid for gasoline for country people willing to drive through their district to get people to vote for consolidation. While farm newspapers sometimes noted that the location of a rural school was important, they seldom addressed the town versus country implications of school consolidation. Rural Midwesterners saw this as the central issue. ${ }^{77}$

The final argument produced in opposition to consolidation was that rural schools were good enough for their children and did not need to be changed. Correspondents asserted that, contrary to the proclamations of farm newspapers, one-room rural schools had improved. They wrote that their teachers were well-paid and highly-qualified and that their schoolhouses were in good repair. Others noted that rural schools had educated some of the most prominent and most prosperous citizens in history. ${ }^{78}$ Still others combined opposition to consolidation with opposition to education in agriculture and domestic science. One author asserted that farm children could best learn these subjects at home and could best learn the basics in a small school close to home. ${ }^{79}$

It appears that the supporters of consolidated schools wrote to the Homestead in response to the many letters in opposition. As one put it, "Many writers on school subjects [are] not familiar with conditions and make many statements that are absurd." ${ }^{80}$ Most claimed to speak from experience: of the six letters printed in support of consolidation, three were from superintendents of consolidated school districts and one was from a farmer whose children attended a consolidated school. These letter writers rejected the idea that children would be gone from home as long as opponents charged. They supported consolidation with many of the same arguments that farm newspapers themselves presented: improved teachers, buildings, equipment, attendance, instruction, discipline, and supervision between home and school. Finally, the superintendents argued that few of the parents of children in their schools wanted ever to go back to a one-room school. ${ }^{81}$ This common argument-that few consolidated school patrons wanted to return to one-room schools-overlooked the reality that once one's district paid for a large new schoolhouse, usually with a bond issue, there was no economically feasible way to return to the old system.

In this way, the Homestead became a forum for the discussion of consolidation, not just a promoter of the reform. Many wrote in opposition to consolidation, giving mainly local reasons: objections to long wagon trips, dislike of higher taxes, suspicion of town people's intentions, and belief that one's local school was adequate. Those who wrote in support of consolidation also did so for local reasons; most supporters were involved with consolidated 
schools and defended their participation. These letters suggest that there was significant opposition to consolidation among rural Midwesterners.

A series of letters written to the Prairie Farmer during 1920 also support these conclusions. Letter writers who opposed consolidation had one main argument: too many consolidations resulted in towns enriching their school districts at the countryside's expense. J. H. Matthew from Shelby County spoke for most of the opponents when he described consolidation as "a scheme whereby a city can build and maintain an expensive school at the expense of the farmer." 82 One correspondent described an election in his district where the vote was 3 votes for the consolidation, 215 against it. Those who wrote in support of consolidation also did so for one reason: they argued that a consolidated school meant a better education. It appears from the Homestead and Prairie Farmer that as many country people were against consolidation as were for it. ${ }^{83}$

Unlike these papers, which provided special opportunities for the discussion of issues in features such as "The Experience Meeting" and "What the Neighbors Say," Wallaces' Farmer gave space to letters about rural school issues on a regular basis throughout the period. Therefore in contrast to the snapshots of rural opinion on consolidation given in the Homestead and Prairie Farmer, Wallaces' provides a look at opinion over a number of years. I have found thirty-two letters published between 1897 and 1920 that refer to consolidation. Sixteen of these were in favor of consolidation, and sixteen opposed it.

The letters Wallaces' Farmer printed in opposition to consolidation gave the same reasons as letters to the Homestead. The two most important reasons were increased costs (leading to higher taxes) and transportation problems. Correspondents stressed higher taxes in letters early in the period, possibly because consolidation's proponents still argued that consolidation meant lower costs. By the 1910s, supporters had abandoned this assertion. The problems of transportation provided a consistent objection. As one correspondent put it in 1902, proponents wanted country people to load their kids onto a wagon like livestock and have them hauled several miles to school each day:

Just think of sending our dear little children of five or six years away from home at a few minutes past seven o'clock in the morning, both summer and winter, and not seeing them again until nearly six in the evening, and the boys and girls who are good to be packed into the same wagon with any child, good or bad, that happens to live on our road to school. "Evil communications corrupt good manners," and all country children are not good. ${ }^{84}$ 
Other writers asserted that the real answer was to improve one-room schools. ${ }^{85}$

The sixteen individuals in favor of consolidation supported the consolidated school because they believed that it improved education, it cost less than one-room schools, it kept farm children in the country, and it enabled the teaching of agriculture and domestic science. ${ }^{86}$ Over time, letter writers dropped the assertion that consolidation was less expensive. They added the argument that few whose children attended consolidated schools wanted to go back to the old way. A similar proportion of letters were written by those involved with a consolidated school than those in the Homestead-seven of the sixteen letters came from people who either had children in consolidated schools or worked for one. ${ }^{87}$ Overall, these correspondents supported consolidation for the same reasons given in the editorials and articles printed in the paper.

Several letters from consolidated school superintendents even defended consolidation with town schools. The superintendents contended that consolidation with town schools provided a better education than oneroom schools. They viewed improved education as a sufficient reason for farmers to send their children to town for school. One writer even asserted that contrary to popular belief, children's morality in town was better than that in the country, for the free time at school in town was devoted to "directed play or competitive games." Because low enrollment made organized sports impossible in the country, children's minds were often "given to vicious thoughts." 88 Another simply described the rural and town patrons of his consolidated district as cooperating, not competing. ${ }^{89}$

Many letters to the Missouri Ruralist addressed the rural school, but few mentioned consolidation. Ruralist correspondents were much more likely to debate agricultural education, teacher's salaries, and improvements to the one-room schoolhouse.

Previous histories reveal that widespread school consolidation did not become a reality in the rural Midwest during the early twentieth century. In 1920, by the United States Office of Education's count, there were 11,340 one-room schools in Iowa and only 288 consolidated schools. In Illinois, there were 10,145 one-room schools and 78 consolidated schools. In Missouri, 8,066 one-room schools existed beside 168 consolidated schools. ${ }^{90}$ Consolidation did not come to the Midwest until after the Second World War. By then the process was called "reorganization," it was required by law, rural population loss was more acute, and rural Midwesterners had an additional forty years experience with large, bureaucratic institutions. ${ }^{91}$ 
These interactions suggest that there was significant opposition to the program of farm newspapers, educational reformers, and Country Life leaders among readers of farm newspapers. Rural Midwesterners chose carefully between the reforms promoted by educational reformers. While many farmers rejected both agricultural education and school consolidation, it appears that country people supported agricultural education more than consolidation. Historians have disagreed on the reasons rural Midwesterners opposed consolidation. Farm newspapers' treatment of consolidation provides insight on this contentious question.

\section{HISTORIANS AND RURAL OPPOSITION TO CONSOLIDATION}

Why did rural Midwesterners resist consolidation? A number of scholars have written on the subject, including Hal Barron, William Bowers, David Danbom, Wayne Fuller, James Madison, David Reynolds, and Paul Theobald. Each author gives explanations for opposition that may be divided into "surface level" and "deeper level" explanations. The deeper level reasons are described as the "real" reasons that country people opposed consolidation.

The surface level explanations are those revealed in my research. Rural Midwesterners expressed opposition to transportation because of long rides, the threat of cold and disease from drafty wagons, and the threats to morals from drivers. Opponents did not want higher taxes. They wanted their children educated in the country. Many were dubious about the motives of townspeople who sought consolidation with country districts. Finally, they asserted that their own local schools were good enough. All of the authors listed above identify these surface reasons for opposition to consolidation.

For all of the authors, however, these were not the "real" reasons. For Barron, Danbom, Fuller, and Madison, the deeper reason was that rural Midwesterners were opposed to outside interference and prized local control. Both of these attitudes were legacies of a traditional rural belief in Jeffersonian democracy. For the most part, these scholars pit country people against outside experts, such as educational reformers and Country Life leaders. Madison, Fuller, and Danbom mainly use the records of these reformers, so they read between the lines to find out what animated consolidation's opponents. Barron actually finds quotes from country people in the Obio Farmer and local newspapers to support his contention that farmers were uneasy with impersonal, bureaucratic, expert leadership. ${ }^{92}$

Still, this explanation does not address why some rural Midwesterners embraced consolidation. If Jeffersonian democracy and local control were 
so much a part of country people's worldview, why did some rural districts consolidate? Why did some rural readers write to farm papers in support of the consolidated school? Barron addresses this briefly, allowing that some schools consolidated to save money or to gain state aid. But he argues that unlike rural road improvement, where technology and state money turned opposition into interest group politics by the $1920 \mathrm{~s}$, farmers remained opposed to school consolidation much longer. ${ }^{93}$ Thus, this explanation fails to explain the motives of supporters of consolidation.

Paul Theobald's work directly attacks these authors' explanations for rural Midwesterners' resistance, calling it the "Conventional Account." $\mathrm{He}$ offers a different "real reason" for why country people opposed educational reform. He charges that anti-intellectualism, anti-foreign sentiment, and the desire of district leaders to protect their power over land led rural Midwesterners to oppose consolidation. He too mainly uses the records of educational reformers and literary evidence and reads it back to the attitudes of country people. Also like the others, his view does not address why some farmers embraced consolidation. ${ }^{94}$

Geographer David Reynolds offers a still different "real reason" for rural Midwesterners' opposition to consolidation. He calls resistance a "place-based class movement." 95 A historian might call this a matter of mentalité. Those who saw farming primarily as a way of life and wanted to preserve their rural neighborhoods and kinship networks as working communities opposed school consolidation. Those who saw farming as primarily a way to make money and were not attached to their neighborhood communities-or who saw a larger community with which to identifyworked for school consolidation. Unlike the other explanations, Reynolds's can explain why some country people worked for consolidation.

Reynolds supports his interpretation by describing the formation of the Buck Creek Consolidated school in rural Delaware County, Iowa. There, supporters of consolidation desired to build a new, progressive, Protestant place. But this place was largely planned by outside leaders: two pastors of the local Methodist Church, both from outside the community and both greatly influenced by the Country Life movement. We do not hear the actual voices of individual members of the church who supported consolidation or those who opposed it. Like the other authors, Reynolds must infer the motives of rural Midwesterners from contemporary newspaper accounts and legal records, which he supplements with interviews conducted sixty years after the events described. Instead of describing country people as opposing consolidation because they opposed outside leaders, he describes consolidation supporters as following charismatic leaders from the outside, not supporting it for good reasons. ${ }^{96}$ 
My research has not uncovered quotes that reveal the importance of Jeffersonian democracy to country people or their opposition to outsiders. It likewise has not revealed intimations that anti-intellectualism, neighborhood power struggles, or place and class were the "real" reason that consolidation was opposed. My sources suggest that such decisions were intensely local and that opposition was for intensely local reasons. When rural Midwesterners sat down to put on paper their reasons for opposing consolidation, they wrote about local issues. They were dismayed at the prospects of transporting their children to school, they objected to paying higher taxes when they believed the education their children received was sufficient, and they suspected town people did not consider rural interests when they worked for consolidation. Perhaps the "real" reason lies in the practical considerations made by individual farm families: transportation, money, and suspicion of towns.

The treatment accorded the rural school in the Midwestern farm press reveals the significant influence of progressive social reformers. Since editors and owners lived in large towns and cities, they were in the position to solicit the opinions of educational experts and Country Life Leaders on these issues. Farm newspapers communicated the program of these reformers to country people.

Midwestern farm newspapers also provided a forum where farmers could discuss these reforms. Farm papers presented progressive reformers' plans for rural society and then allowed country people to respond to that plan. When rural Midwesterners ideas were published in farm newspapers as letters to the editor, it revealed that they both accepted and rejected the papers' recommendations. Agricultural education seems to have been more popular among farmers than was rural school consolidation. Country people appear to have supported or opposed consolidation based on their own local circumstances more than overarching philosophical or socio-economic reasons. For whatever reason, in many rural communities the schoolhouse remained at the crossroads-both literally and figurativelywell past 1920. 


\section{Chapter Seven}

Why Leave the Farm?":'

\section{The Rural Family and the Midwestern Farm Press}

Husband and wife should be full partners in all of the work on a farm and should share equally in the proceeds therefrom. The husband should do the work on the farm and the wife should look after the house, and with the soapmaking, caring for the chickens, etc., she will have plenty to do to keep her busy.

Husband and wife should be partners in the fullest sense of the word, both in planning the business necessary to successfully conduct the farm and in the bringing up of the children who will in the future be filling the stations in life the parents now fill.

- E. E. Buck, Prairie Farmer ${ }^{2}$

The hope of agriculture in the future lies in the boys and girls who are now going to school. If we can but get them to open their eyes and see what nature is doing around them all summer long in the formation of leaf, flower, and fruit, the prosperity of agriculture in the future is assured beyond question, no matter what political party governs the country.

- Henry Wallace, Editor, Wallaces' Farmer ${ }^{3}$

An understanding of work roles within the farm family and community is fundamental to an understanding of rural history. Historians have long argued that the family organized the lives of country people. Calls for historians to consider the role of religion in rural life have only recently been made and have often gone unheeded. By contrast, James Henretta and John Mack Faragher's calls for rural historians to study the rural family have prompted a series of excellent works examining the nature and role of the family in agriculture and country life. ${ }^{4}$ 
In the nineteenth century, farming was a family project. Gender roles were primarily defined by the make-up of the family. Farm men worked in the fields and stockyards. Farm women worked in three areas: 1) in the household: raising children, preparing food, sewing, and cleaning; 2 ) in the farmyard: producing poultry, dairy, and garden products for home consumption and for the market; and 3) in the fields: helping their husbands with livestock, planting, cultivation, and harvest. Earlier scholars made confident statements about what women did and did not do on Midwestern farms. More recent research, however, has pointed out the flexibility of the gender division of labor. It appears that the gender distribution of work varied greatly depending on the wealth of the farm family, the type of agriculture pursued, and other factors such as ethnicity and individual inclinations. ${ }^{5}$ It is clear, however, that women worked in both productive and reproductive roles. They produced agricultural commodities for the market and reproduced the farm family by keeping house and training their children. With the coming of mechanized and specialized farming, women's participation in the production of farm commodities decreased. Reformers worried that women were unhappy in their roles on the farm and might encourage their husbands to move to town. Farm newspapers addressed these changing roles and anxieties.

Children also provided labor for the farm and household. Sons helped their fathers in the fields and daughters helped their mothers with housework. Children of both genders helped out in other areas in keeping with established family patterns. Farm families often educated sons to take over management of the operation from their father, and they raised their daughters to be happy and successful farmers' wives. In the early twentieth century, however, more and more children were leaving the farm for towns or cities. This exodus made for anxiety among farm families and especially among country life observers and reformers. Farm papers also addressed this anxiety.

This chapter will assess farm newspapers' descriptions of the farm family, including women's work on the farm and the roles of farm children. Midwestern farm newspapers were a conduit for social reformers' advice on issues confronting the rural family, much as they had for the rural church and the rural school. Farm papers also provided a forum for rural Midwesterners to respond to these recommendations.

\section{FARM WOMEN AND FARM NEWSPAPERS}

Midwestern farm newspapers addressed a wide variety of issues confronting farm women. All four of the papers studied included Home departments, usually edited by women. Home editors wrote articles about the 
farm woman's life and duties and selected letters from subscribers to print. Such letters described how readers went about their work. They explained how readers dealt with particular issues. In addition, all four papers printed feature articles about issues facing farm women and confronted those issues on their editorial pages.

The treatment of the rural family by farm newspapers was not as focused as their coverage of the rural church and the rural school. Instead, a number of different issues were addressed without consistent, overarching recommendations for the farm family. In addition, there seems to be little change over time in farm newspapers treatment of the issues. Five themes may be identified that organize the treatment of women in farm newspapers. First, farm newspapers called upon women to make use of labor-saving devices for the farm home by persuading their husbands to purchase such conveniences. Second, just as farm newspapers called on farmers to adopt scientific farming practices, they enjoined farm women to put into practice new housekeeping methods, in keeping with the science of domestic economy. Third, farm papers described poultry-raising as an activity especially suited for women and described successful women poultry raisers. Building on farm women's participation in poultry raising and decision making, papers went on to depict farm wives as the full partners of their husbands in the farm enterprise. Finally, farm newspapers described women who owned and managed farms themselves.

The authors of farm newspaper stories and editorials were anxious about women's attitudes toward their lives. Many authors feared that unhappy women contributed to outmigration from rural areas by encouraging their husbands or children to leave the farm. They gave recommendations for keeping farm women happy that show the influence of the Country Life Movement and the Domestic Economy movement of the early twentieth century. Midwestern rural women were selective in how they responded to this advice.

The primary theme in farm newspapers coverage of farm women was their recommendation that they get their husbands to buy labor-saving conveniences for the farm home. Henry Wallace suggested in 1910 that prosperous corn-belt farmers could afford a farm home with "furnace heat, hot air or hot water, sewage, hot and cold water bathroom, and some system of lighting other than the old-fashioned kerosene lamp."6 The Iowa Homestead, in addition to these conveniences, recommended that the farm woman be given a gas engine for washing clothes and electricity for a vacuum cleaner and refrigerator. ${ }^{7}$ The Prairie Farmer argued eloquently for labor-saving devices: 
Farm women must always work, and they do it willingly. But the useless work-the work that machinery can do so easily-ought to be taken from their shoulders. They will have more time to spend in doing the thousand and one things that make life more worth living for everyone-things that we men couldn't do if we tried. ${ }^{8}$

In addition to the conveniences given above, the Prairie Farmer suggested improvements to the kitchen such as windows, a long work table, a gas range, and a fireless cooker. The paper eventually suggested that the farm woman could put a car to good use. The Missouri Ruralist made similar recommendations. ${ }^{9}$

The purchase of labor-saving conveniences for the rural home was one facet of a larger campaign for the systematic study of housekeeping that was alternately called domestic science, domestic economy, and home economics. ${ }^{10}$ Home departments in farm newspapers also supported domestic science education for farm girls. ${ }^{11}$ Farm papers encouraged farm women to study their own housekeeping in order to make it truly scientific. The Home Department of the Missouri Ruralist printed a series of articles by a Missouri State Institute Lecturer on domestic science issues. Her articles described how to cook nutritious food, save steps in the doing of housework, and clean and sanitize the home. ${ }^{12}$ Cooking was seen as especially important. Again, the editor of the Prairie Farmer poetically described the plight of the husband of a poor cook:

It is hard for a man to keep affection alive in his soul when he has a heavy biscuit in his stomach. Burned steak and soggy bread have been the rocks on which many a happy matrimonial craft has been wrecked. Love and a poor digestion cannot abide in the same household, and family dissention and scorched beans are boon companions. ${ }^{13}$

This lament was offered in all seriousness. Authors considered cooking vital to the happiness of the farm family. Finally, farm papers recommended that farm wives use their money wisely and run their household like a business, organizing their work carefully and keeping written accounts. ${ }^{14}$

Another theme consistently addressed by farm newspapers is the ability of farm women to make money with poultry. In 1905 Wallaces' Farmer asserted that "As a rule women are more successful in raising chickens than are men. They are more careful, pay more attention to detail, and give more time to the work than a man would think worth while." 15 A later editorial argued that "One of the most difficult of the tasks of the farmer's wife is to overcome the men's inherited prejudices against poultry keeping, and to arouse their interest in it.... How to persuade a farmer that the chickens should be planned for as the rest of the flock is planned for is the problem." 16 Many articles in the 
other papers also described successful poultry raisers and how they had succeeded. A feature in the Iowa Homestead praised an Illinois farm couple, the husband of which was "wholly carried away with what the wife is doing with her hens, and says she shall be offered every means that will make for her success, but she shall remain as the manager of them." 17 One U. S. D. A. extension agent's report found that eighty-one percent of ten thousand farms surveyed in thirty-three northern and western states kept poultry. The key role of poultry-keeping in the lives of Midwestern farm women (and the incomes of Midwestern farms) has been described by Deborah Fink. ${ }^{18}$

Such cooperation between farm husbands and wives was another theme in farm newspaper's coverage of women's roles in the farm operation. Farm papers exhorted farmers to treat their wives as partners in the farming enterprise, and they urged farm wives to participate in the farm decision making. As early as 1900 , a Prairie Farmer column suggested that husband and wife should be full partners in the work of the farm and share proceeds equally. The author argued that both should cooperate in planning the farm operation, and each should have an equal right to money when needed. In addition, men should consult their wives when undertaking something important, because sometimes the wife had a better perspective on the situation. ${ }^{19}$ Partnership between farm men and women was also a theme in the Missouri Ruralist, where editor John F. Case argued in 1914 that the farm woman "should be an equal partner." A 1915 feature argued that "Whether a man succeeds or fails depends to a large extent upon the help his wife gives." The other two papers printed similar articles. ${ }^{20}$

Farm newspapers' coverage of farm women, however, went beyond description of and recommendations for farm wives concerning their work in the house, in the poultry-yard, and in farm decision making. Farm newspapers also described the successes of women who owned and managed farms themselves, especially in feature stories. Laura Ingalls Wilder wrote for the Missouri Ruralist of Mrs. C. A. Durnell of Mansfield, Missouri, who "Reclaimed a Farm, Built a House in the Wilderness, and Learned the Secret of Contentment." ${ }^{21}$ Several Prairie Farmer articles described unnamed women farm operators who made thousands of dollars on their investment in Illinois land. ${ }^{22}$ A Wallaces' Farmer feature profiled Mrs. M. D. Longshore and her single daughters Caroline and Marie, who together operated a four hundred acre farm in Dallas County, Iowa:

This is a short story concerning three Iowa women who are really farming-not playing at it. They do not dress up in men's clothes and pose for their pictures for magazines and sensational dailies. They do not drive out to the farm late in the morning, putter around for an hour or 
two, and then drive back for tea at the country club. They farm. They farm just as men do and just as successfully. ${ }^{23}$

The piece described how the women cared for their hogs during a cold snap the previous winter, shrewdly bought cows to feed and sell, and chose a good crop rotation for their fields. The Iowa Homestead printed several editorials arguing that women could farm as well as men and should be encouraged to do so. ${ }^{24}$

In presenting this description of farm newspapers coverage of rural women, one should not assume that all of their depictions were positive. Farm newspapers' calls for farmers to purchase labor-saving devices for their wives and to make their wives full partners in the farm enterprise suggest that many farmers did not do these things. Still, writers were optimistic that the best farmers would take their advice and make life better for their wives, just as they were optimistic about the success of all of their recommendations.

Relatively few articles touched on the darker side of rural marriages by addressing rural divorce or domestic violence. Articles in Wallaces' Farmer, the Iowa Homestead, and the Missouri Ruralist all condemn divorce, but they also suggest that it was relatively uncommon in rural areas. A 1911 editorial in Wallaces' Farmer goes so far as to give five reasons why there were so few divorces in the country: 1) the importance of the farmer's wife to the farm's operation, 2) courtship conducted under church and neighborhood scrutiny, 3) church weddings where a pastor explains the solemnity of the contract, 4) farmers' lack of need to fit in with high society by changing wives, and 5) the peace and quiet afforded by the country. Most likely this was an overly optimistic view of rural marriages. ${ }^{25}$ The darkest side of rural marriages-domestic violence in farm homes-was never mentioned by farm newspapers. ${ }^{26}$

The ideas of Country Life reformers influenced farm newspapers' advice to rural husbands and wives about their families, much like those ideas influenced farm papers' recommendations for the rural church and the rural school. Country Life leaders were very concerned for the farm woman's happiness on the farm. They worried that dissatisfied women might encourage their husbands or children to leave the farm for life in town. The Report of the Country Life Commission offered a number of suggestions to improve the farm woman's lot. The commission recommended that farmers purchase labor-saving devices for their wives as soon as it was economically possible for the family. It also called for the teaching of domestic science in the school so that women would be equipped to run their households efficiently. ${ }^{27}$ 
Midwestern farm newspapers communicated these ideas to rural Midwesterners.

The burgeoning domestic economy movement also influenced these recommendations. During the Progressive Era, teachers at agricultural colleges, farmers' institute lecturers, and bureaucrats in state departments of agriculture and the U. S. D. A. came to advocate the scientific study of housekeeping. Their recommendations were issued in bulletins, printed in books, and eventually taken to farm families directly by home extension agents. It is clear that farm newspapers also acted as conduits for these ideas. ${ }^{28}$

Farm newspapers went well beyond the recommendations of the Country Life Movement and the closely-related Domestic Economy movement. The Country Life Commission's Report does not mention the women's work in agricultural production, be it poultry, dairying, garden, or management of farms. That farm newspapers provided a broader picture of women's work in the farm operation suggests that they had a more complete view of the entire life of the farm family.

This broad view of what women contributed to the farm enterprise is an important feature of Midwestern farm newspapers' coverage of women's roles. They did not recommend that women restrict themselves to housekeeping pursuits or that they should concentrate solely on domestic achievements. Even in the early twentieth century, the withdrawal of women's labor from farm production was impossible for most Midwestern farm families. While publications such as the new magazines of the 1890s and 1900s promoted views of women as primarily as domestic consumers, ${ }^{29}$ farm newspapers recognized that in rural areas, they continued to be producers. Mary Neth and Katherine Jellison have both traced a drive among agricultural institutions such as agricultural colleges, farm newspapers, and the U. S. D. A. to define men as the decision-makers in farm operations and women as domestic consumers. The Country Life and domestic economy movements certainly suggest a move towards domesticity. The farm newspapers examined for this project, however, do not reflect these sentiments. Furthermore, Neth and Jellison's descriptions are mainly of developments in the 1920s prompted by the stress of agricultural depression. During the more prosperous first two decades of the century, farm newspapers described farm women as an integral part of the agricultural operation and recommended that they be treated as such. ${ }^{30}$

The response to these recommendations, as in the other areas of social advice given by farm newspapers, was mixed. Letters to the editor printed in farm papers provide an even more complete view of women's position in 
the farm family in the early twentieth century. Many letters supported the adoption of labor-saving devices. "A Farmer's Wife" wrote to Wallaces' Farmer that while she had been raised in town, she enjoyed being a farmer's wife because she had a variety of work and her husband had provided running water, a bathroom, a furnace, and an ice house for her convenience. ${ }^{31}$ Numerous letters appeared in Home departments that gave housekeeping tips and ways to do household chores more efficiently or easily. Correspondents to several papers also encouraged the raising of poultry by women, telling their own success stories in the process. ${ }^{32}$

In addition, there are several letters from women who managed their own farms. Mrs. Theodore Saxon told Wallaces' Farmer that she knew how to do all the work of the farm so that she could intelligently supervise her male hired help or step in and do the work herself if necessary. ${ }^{33} \mathrm{~A}$ "Farmer Bachelor Girl" wrote to the Ruralist that her life as a woman farmer was happy. While she worked hard, she was independent. She concluded, "Of course I am an old maid and run things as I please, which makes any woman happy. . . . I think it is the married women that are unhappy on the farms, and no wonder." 34

This letter suggests that in the area of husband-wife relations, the realities of rural Midwestern life were not always as farm newspapers described them. While a number of letter writers agreed with farm papers that farm couples should be partners in the farm enterprise, they sometimes described situations that fell far short of this ideal. One noted, "there is certainly something very pitiful and discouraging in being a worthless farmer's wife." Her husband took the money she made from the poultry and garden and did not allow her a say in how the farm was run. Another spoke of a grumbling husband. A third complained, "I have known wives who have tried for years by every gentle means known to the sex to win a little affection or even appreciation from a husband and utterly fail" and wondered if divorce was never to be an option. Many women were more concerned with how they were treated by their husbands than whether they got household conveniences. ${ }^{35}$ Other writers, however, repeated the farm papers' assertions that they were full partners in the farm operation. One Prairie Farmer correspondent asserted that "on a farm the wife is quite as important as the husband." An entire page of letters in the Missouri Ruralist argued for the importance of the farm woman to the farm operation. ${ }^{36}$

Social histories of the period address women's reception of the country life movement and the domestic economy movement, but several offer contrasting interpretations. David Danbom depicted rural women as resisting the recommendations of domestic science experts because the experts 
were outsiders. In addition, Mary Neth and Katherine Jellison have described rural women as opposing the adoption of labor-saving conveniences, although they were pressured to do so. ${ }^{37}$ Marilyn Irvin Holt and Dorothy Schwieder, on the other hand, argue that farm women embraced the innovations that they thought would make their lives easier. ${ }^{38}$

The evidence from farm newspapers supports the conclusions of Holt and Schwieder. Farm women welcomed systematic ways of doing housework and mechanical conveniences when they felt that they would lessen their work. They embraced farm newspapers' promotion of poultry work and agreed that women could manage farms. Farm women supported the idea of the farm marriage as a partnership in the running of the farm, but they also provided descriptions where the ideal was not met. Farm women selectively adapted the program of domestic economy delivered through farm newspapers; they did not resist it completely. ${ }^{39}$

\section{COMMUNITY-BUILDING IN THE HOME DEPARTMENT}

While farm newspaper editors and writers worried publicly about keeping farm women happy in the country, farm newspapers themselves were creating an important space for the formation of communities of rural women. Cultural historians have described "communities of print" where geographically scattered groups of people are brought together by print publications. ${ }^{40}$ In a similar way, readers of farm newspapers were able to use farm papers to create communities.

The primary location for such communities was the Home department. Home departments devoted a significant amount of space to letters from readers about issues of concern to country people. At times, other readers responded to ideas and positions voiced in letters. Their letters might in turn bring a response from the original letter-writer. Some departments featured letters from a number of correspondents on a regular basis. Every week the same group of several dozen women (and some men) wrote not only to discuss issues of importance to farm women but also to comment on happenings in their lives, in their families, and in their neighborhoods. In time, these interactions became actual communities. Home editors encouraged readers to express themselves and correspondents wrote about a variety of issues, including the happenings of their daily lives.

The Home Department of the Iowa Homestead between 1895 and 1915 created just such a community. The pattern for the department was set by Velma Caldwell Melville of Sun Prairie, Wisconsin, department editor from 1895 to 1898 . Each week most of the material in the department was printed under the title "Among Ourselves." Between three and ten letters 
from readers appeared in this space. Melville introduced and commented on most of them. Regular correspondents included Margery Barnes, Margaret Flindt, Mrs. A. H. Seaman, and about fifteen others. The column was filled out with occasional or one-time letter-writers. In 1898, Melville left and the new, unnamed editor added an introduction to the department titled "With the Editor." Several subsequent editors continued "Among Ourselves" and "With the Editor." These columns in the Home Department were discontinued in 1916. After the middle of that year, the department offered more advice to farm women and less space for discussion and community building. ${ }^{41}$

In the 1890s, correspondents to the "Hearts and Homes" department of Wallaces' Farmer turned its community of readers into an actual organization: the Daughters of Ceres. Nancy Wallace, the wife of the first Henry Wallace, edited the "Hearts and Homes" department from 1895 to shortly before her death in 1909. From the beginning of the department, Nancy Wallace had encouraged the formation of local rural women's clubs. In late 1896 , one correspondent suggested that a statewide organization of rural women's clubs be formed. Nancy Wallace suggested the name "Daughters of Ceres" in January of 1897, and in several months two chapters had been formed. The state organization was officially constituted at a meeting in the Wallaces' Farmer tent at the Iowa State Fair in September of that year. By 1910 , seven chapters existed, and the state organization held yearly meetings in the Wallaces' Farmer tent at the state fair. Women from the various chapters met, presented papers, and visited. ${ }^{42}$

By the 1910s, such communities in Home departments of Midwestern farm newspapers were much rarer. In the Prairie Farmer, the Girls and Children's departments had created small-scale communities briefly between 1895 and 1900. Much of Prairie Farmer's Home department, however, had always been instructions delivered by the editor of the department or other writers. This focus on the giving of advice continued after the turn of the century. Furthermore, "Hearts and Homes" in Wallaces' Farmer became a much more didactic department after the death of Nancy Wallace in 1909, and the Homestead discontinued "Among Ourselves" in 1916. The Home department of the Missouri Ruralist never approached the level of community achieved in the Homestead or Wallaces.'

These communities seem to have developed and flourished outside of farm newspapers' program to keep women on the farm by improving rural life. In fact, it appears that as agitation for social reforms increased in the 1910 s, Home departments were increasingly used to communicate recommendations for making the life of the rural family better. But while they do 
not appear to be part of farm newspapers' program for the improvement of rural life, it is probable that they did in fact improve the lives of some rural Midwesterners substantially. Rural women who did not have access to a local women's club or other neighborhood institution could find a sympathetic ear by writing to the home department of their farm newspaper. Thousands of letters attest to rural women's interest in building community with other women. Ironically, at the same time that farm newspaper editors worried about keeping rural women satisfied in the country, they discontinued a departmental pattern that must have provided satisfaction to many rural women.

\section{FARM CHILDREN AND FARM NEWSPAPERS}

Children were also vital to the Midwestern farm operation. Throughout the nineteenth century, their labor in the household, in the barnyard, and in the fields was economically necessary for survival on the frontier and for a generation afterward. As survival became more certain during the early years of the twentieth century, their labor became less indispensable on some farms, but nearly all farm children continued to work in some capacity.

Children were trained from an early age to do a variety of chores. As they grew older, the gender division of labor was applied to boys and girls in differing configurations, depending on the same variables described above: wealth, type of farm, ethnicity, and familial expectations. For the most part, however, boys helped their fathers in the fields and feed lots, girls helped their mothers in the house, farmyard, and garden. At the turn of the twentieth century, city people were beginning to view their children as economically useless but emotionally priceless; as a result, many supported such measures as prohibitions of child labor and compulsory school attendance laws. While country people were certainly emotionally attached to their children, they continued to view children as economically valuable and to make use of their labor in production. ${ }^{43}$

At the turn of the twentieth early, however, the beginnings of outmigration from Midwestern rural areas turned Country Life leaders' attention to the lives of children. At least some of the sons and daughters of farmers were forsaking the countryside to seek their fortune in towns and cities. Social reformers proposed a number of solutions to this problem. ${ }^{44}$ Farm newspapers communicated their recommendations to rural Midwesterners. Authors advised farm boys and farm girls to stay on the farm. Farm newspapers instructed their parents in why they left the farm and what could be done to stop the exodus. Farm newspapers treated young men and women in different articles with different emphases and arguments. 


\section{Farm Boys}

The pattern of farm newspapers' coverage of young men leaving the farm is similar to their coverage of the rural church. ${ }^{45}$ Before 1905 , editorials in several of the four farm newspapers noted that more farm boys were choosing town over rural occupations, but they maintained that it was up to the individual boy to decide. After that year, however, farm newspapers increasingly described the movement as a crisis. Editorials and articles presented arguments for staying on the farm, reasons children left the farm, and ways to keep them on the farm.

In 1901, the editor of the Iowa Homestead argued that it was good that not all farm boys stayed on the farm, for the departure of talent from rural areas strengthened urban areas. "Nature never intended that they should [stay]," he argued. "It is the fresh, vigorous blood from the country that keeps up the brains in the city. Were it not for this constant infusion of fresh blood, cities would degenerate." 46 The author argued that all farm boys should get as much education as possible, so that they will be equipped either to get into college, to obtain a good job off the farm, or to be an intelligent farmer. It was left up to the boy to make the choice. Similar sentiments are found in several other Homestead editorials before $1904 .{ }^{47}$ Henry Wallace echoed these comments in Wallaces' Farmer, even arguing that it would be a misfortune if all farm boys stayed in the country. "The rural districts would soon be over-populated while the urban or city districts would decline in energy and power for lack of being constantly supplemented by the fresh blood from the farm." 48 Wallace was confident that farm boys who moved to the city would succeed because their training on the farm taught them industry, economy, truthfulness, and uprightness. ${ }^{49}$

A counter-current of advice to farm boys to stay on the farm also appeared in Midwestern farm papers, however. G. W. Clark argued in the Prairie Farmer that farm boys should stay in the country and farm. "It is very rare that a farmer's boy who goes to the city ever rises very high in the scale of fortune," he wrote. ${ }^{50}$ An article in the Missouri Ruralist compared the farm work with factory work. The author admitted that farm work sometimes was drudgery, that some mornings there might not be enough light, and that some farm fathers might be hard to work for. But the article contended that factory work was always drudgery, that many factories never had sufficient light to work by, and that many employers were as bad or worse than parents. Even the Iowa Homestead printed an article in 1902 that supported life on the farm at the expense of life in the city, noting the latter's overcrowded labor market and rundown tenement buildings. The author argued that those who had a good farm upbringing should stay on the farm. ${ }^{51}$ 
After 1905, farm newspapers united in their campaign to keep the sons of farmers on the farm. Articles described the possibility of continued rural population loss as a crisis. Continued outmigration was seen as harmful both for those country people who left and for the areas they left behind. Editors and other authors gave a number of ways to encourage farm boys to remain on the farm. Farm papers promoted the teaching of agriculture in rural schools. They argued that farmers should give their sons aspects of the operation to run by themselves in order to make their own money. Finally, they asserted that improvement of the farm surroundings helped to keep boys in the country.

Farm newspapers' promotion of agricultural education as a way of keeping one's children on the farm is described in detail in chapter six. Farm newspapers gave detailed instructions for how to include agriculture in the rural school curriculum. The Iowa Homestead argued that agricultural education encouraged farm boys' natural desire to do even better than their parents had done. Such education opened boys' minds to ways they could surpass their father's achievements on the farm and spurred them to ever greater accomplishments. If their natural impulses towards farm work were discouraged, they would become discontented and might be lost to the country. ${ }^{52}$ The Prairie Farmer's Rex Beresford offered an eloquent argument for agricultural education:

The boy who becomes imbued with the spirit of the country, whose eyes are opened to the possibilities of the farm; and whose brain is trained to take advantage of those opportunities-that boy will never leave the farm for an uncertain existence in the city. His training in agriculture and in the appreciation of things natural will increase many fold, his value to himself, his neighbor and to society. ${ }^{53}$

While many Midwesterners kept their children away from school to work on the farm, farm newspapers suggested that the teaching of agriculture helped to keep boys from leaving for town. Farm newspapers also instructed farmers to give their sons a portion of the operation to call their own. Authors argued that farm boys should be given some way to make money for themselves, for earning their own money developed their sense of responsibility and made them more excited about becoming a farmer. Articles suggested that boys be given a calf, pig, or lamb to raise and sell. Such a project not only taught them about the care of stock, but it also instructed them in the value of money. As for older children, farmers might rent them a small plot of land on which to plant, cultivate, fertilize, and harvest the crop of their choice. The Prairie Farmer argued that "training of this kind is worth 
more to him than a course in a business college. It is the kind of training that develops character and makes good farmers." 54 Other editorials rebuked farmers for giving their children stock to raise and then not allowing them to keep the proceeds. In 1915, the Homestead printed a letter from such an aggrieved son, and James M. Pierce vented his fury against the boy's father. ${ }^{55}$

Finally, farm newspapers argued that country people needed to make the farm more attractive to their boys. Making country life appealing encompassed many different types of recommendations. Some suggested that farmers lessen the work they required of their sons so that they would not become disgusted with farm work. ${ }^{56}$ Others supported social activities such as farm youth clubs. ${ }^{57}$ Still others recommended that the farm home itself be made more attractive, with more comfortable rooms, more reading matter, and additional time for leisure. ${ }^{58}$ Writers hoped that such improvements in rural life would encourage boys to view the country positively. Then they would not leave for the unknown benefits of the city.

Thus, Midwestern farm newspapers spent a few years arguing both for the necessity of young men staying on the farm and for letting the decision up to their best judgment. By 1905, however, writers for farm papers had come to see migration from rural areas as a crisis, and directed their efforts towards keeping farm boys from leaving the country.

\section{Farm Girls}

While farm newspapers were conflicted about the necessity of farm boys staying on the farm for a time, they exhibited no such ambivalence about girls leaving the country. All four farm newspapers saw female outmigration as an unmitigated disaster, not only for the rural community but also for the girls themselves. No articles or editorials suggested that it was up to individual young women whether they stayed on the farm or moved to a city. Their consistent message was that young women raised on a farm should stay in the country.

Farm newspapers attempted to persuade young women to stay on the farm in several ways. Farm papers rehearsed the advantages of living in the country. A Prairie Farmer article by "Aunt Belle" described farm girls as enjoying a quieter life, better air, tastier food, more sleep, more opportunities for study, and a more wholesome occupation than girls growing up in the city. She concluded, "the average country girl has a far better chance of becoming a healthy, happy, useful woman than the average city girl. ..." Editorials in the Missouri Ruralist endorsed these sentiments. ${ }^{59}$ Farm papers also described the dangers facing girls who moved to the city. Several authors mentioned the threat of falling into the hands 
of a prostitution ring. Other writers asserted that too many rural girls only considered the bright side of urban living. Henry Wallace cautioned girls not to think only of the cash wages of factory workers, department store clerks, and office workers. He wanted them to consider the long hours of hard work, the aching backs and sore feet, and the daily grind these laborers endured. ${ }^{60}$

Farm newspapers suggested three major ways parents could work to keep their daughters on the farm. The first two are almost identical to recommendations for farm boys: they advised teaching domestic science in rural schools and giving the farm girl a way to make her own money. Third, farm papers called on rural families and communities to provide rural social events for their daughters. Country entertainment, authors argued, kept them from desiring the activities of the town.

Farm newspapers supported domestic science education for girls, just as they promoted agricultural education for farm boys. Authors argued that classes in sewing, cooking, cleaning, and systematic household management prepared them for their future careers as farm wives. Domestic science education also fostered enthusiasm for housekeeping. Authors hoped that the thought involved in being a farm woman might make staying on the farm a more attractive proposition. In addition, a woman could make real material improvements to her own and her husband's life. ${ }^{61}$

As they had recommended for young men, farm papers advised that farm families could keep their young women on the farm by giving them a way to make their own money. One article suggested that girls should be paid for chores around the house. Another encouraged mothers to give their daughters charge of a garden plot or some hens to look after. Furthermore, mothers should allow their girls to keep the proceeds from the vegetables or eggs. A third advocated the sale of canned goods, homemade bread, and poultry products. These recommendations matched farm papers arguments that boys should be given a way to make their own money. Authors argued that girls who had such opportunities became excited about the possibilities available to them in the country. ${ }^{62}$

Finally, farm newspapers asserted that country people must provide social events for their daughters to keep them on the farm. The Prairie Farmer argued that without social opportunities, girls would be drawn to towns and cities. ${ }^{63}$ Articles in Wallaces' Farmer suggested that rural neighborhoods could sponsor picnics, box lunches, and other events to provide variety in the farm family's life. In addition, the rural school should sponsor domestic science clubs. The paper reported on one such successful club in Mahaska county. ${ }^{64}$ The editor of the Missouri Ruralist worried that girls left 
the farm "because of what is termed 'the deadly monotony of rural life." 65 But the paper looked forward to a better future:

With the dawning of the era of universal good roads the social pleasures and comforts of farm life will be greatly enhanced for both old and young; but in the meantime our girls, as well as our boys, should be made to realize that their pleasure and welfare are receiving consideration. ${ }^{66}$

By the 1910s, Midwestern farm newspapers were united in their support for efforts to keep young people - both men and women-on the farm.

While the Report of the Country Life Commission did not mention the place of farm children specifically, the issue is addressed indirectly in the Report's recommendations concerning rural schools. The overall tone of the report also suggests the belief of its writers that the movement of country people to urban areas must be stopped for the good of the country. The question of young people moving away from farms was also referenced in the conclusion to the report.

We need young people of quality, energy, capacity, aspiration, and conviction, who will live in the open country as permanent residents on farms. ... It will be well for us as a people if we recognize the opportunity for usefulness in the open country and consider that there is a call for service. ${ }^{67}$

The campaign to keep farm children on the farm was thus part of the country life program for revitalizing rural areas. Midwestern farm newspapers communicated this campaign to rural Midwesterners.

\section{READERS' RESPONSES}

Letters to the editor can be used to gauge the response of readers to these recommendations about keeping farm boys and girls in the country. Most of the letters that addressed the crisis of youth outmigration agreed with farm papers that children should be encouraged to stay on the farm. Correspondents repeatedly asserted that the city was no place for countrybred youth. One letter to the Iowa Homestead put it graphically:

There are a thousand and one things to degrade and dwarf the mind and body of a city lad that the country boy never dreams of until he has been caught in the cobweb of the city's allurements, upon which every country boy should turn his back with disgust. 68

Other letters agreed that parents should strive to keep their children in the country. ${ }^{69}$ 
Readers also endorsed most of farm papers' methods for keeping children on the farm. One recommendation that correspondents supported heartily was that farm children be given responsibility for one aspect of the operation and be allowed to keep the profits from their effort. After reviewing the reasons that boys left for the city, "A Young Farmer" gave this prescription for retaining them for the farm:

Then give the boy a chance to have something of his own. It will increase his interest in the work and keep his thoughts at home more perhaps than anything else. Nor will it greatly decrease the receipts of the farm. ... And when they are sold encourage the boy to spend the money judiciously and profitably, part of it for his own clothes, and he will feel more independent and manly. ${ }^{70}$

Similar letters appeared in three of the four Midwestern farm newspapers studied. ${ }^{71}$ Wallaces' Farmer also carried letters that supported less work for farm boys and additional social events for all farm children. ${ }^{72}$

The only method that readers opposed with any regularity was agricultural education in rural schools. Correspondents objected to school instruction in agriculture because they thought that rural schools should teach the basics (reading, writing, and mathematics) and that agricultural instruction could be better provided at home. By contrast to this opposition, the teaching of domestic science in rural schools was praised in letters that addressed keeping young women in the country. Mrs. C. E. Fuller wrote to Wallaces' Farmer that young women would stay in the country if they were taught how to make a home and given an enjoyable social life. Arthur Cromwell supported giving practical education to girls at all levels of the rural schools. ${ }^{73}$

From social histories, however, it is clear that despite the best efforts of Country Life reformers and farm newspapers, the exodus from farms continued. Some of this migration was the result of agricultural realities. With the coming of machinery and other farm labor-saving devices, fewer farmers were required to raise crops or livestock on the same amount of land. In addition, between 1900 and 1920, high prices for agricultural commodities drove up land prices. As a result, it became increasingly difficult for sons who were not given land by their fathers to climb the "agricultural ladder" from hired hand to renter to landowner. "Excess" sons and daughters had little choice but to leave the farm for jobs in towns or the city. ${ }^{74}$

In addition, some families hoped for better things for their children than to stay on the farm. They worked to get their children the best education possible, making sure that their children finished high school and sent them to college. ${ }^{75}$ One such farming family was that of Arnold J. Burge, a 
native of Johnson County, Iowa. Burge received his medical degree from the State University of Iowa. After studying in Berlin and Vienna, he returned to teach surgery at the University of Iowa. Henry C. Taylor, after receiving his Masters degree in agriculture from the Iowa State Agricultural College, told his father that he would be happy to come home and run the farm. His father replied, "You are well prepared for far more important work, and there are plenty of people to run farms." Taylor became a professor at the University of Wisconsin and later the Chief of the Bureau of Agricultural Economics at the U. S. D. A. Farm newspaper authors roundly criticized those who encouraged their children to leave the farm. ${ }^{76}$ These families demonstrate that not all those who left the country did so because they were dissatisfied with farming or rural life. Parents directed some to leave, directly or indirectly.

At the turn of the twentieth century, Midwestern farm newspapers printed many recommendations aimed at keeping family members satisfied so that they would stay on the farm. This treatment reflected the position of the Middle West during the late nineteenth and early twentieth centuries: both the region and the United States in general were in the midst of a demographic transition.

The stories of the men and women who left the farm in order to move to towns and cities during these years are intensely aimed at keeping family members satisfied so that they would stay on the farm. At times an entire family made the decision: sometimes because economic or agricultural conditions required the move, sometimes because they took advantage of economic, social, or educational opportunities. At other times, it was an individual decision made by a son or daughter who saw greater life opportunities off the farm. But those who left rural areas were not represented in farm newspapers. Ironically, authors who had moved to cities to pursue careers in journalism wrote numerous editorials and articles to encourage farmers to remain in the country. Readers who corresponded with farm newspapers appear to have agreed with the paper's editors and writers. Authors of letters to the editor asserted that farm life was better than life in the city, and that they hoped to keep their children on the farm by providing them with agricultural opportunities and better living conditions. In this case it seems that readers largely embraced the message of farm newspapers. The exodus from rural areas continued, however, meaning that farm newspapers failed to reach those likely to leave the farm and failed to give them a voice on their pages. 


\section{Conclusion}

\section{"Good Farming-Clear Thinking- Right Living" \\ The Uses of Midwestern Farm Newspapers}

The regional, general farm newspaper was a significant part of rural Midwesterners' lives in the late nineteenth and early twentieth centuries. The years between 1895 and 1920 were years of expansion for Midwestern farm newspapers, just as they were years of prosperity for rural Midwesterners. On average the newspapers studied in this project tripled the number of pages they printed. Advertisements became larger and more elaborate and took up more space in the paper. Farm newspapers reached out to as many country people as they could, and the papers' subscription lists grew accordingly. Together the circulation of the farm newspapers studied increased nearly seven-fold in twenty-five years.

Large percentages of the rural population in Illinois, Iowa, and Missouri subscribed to one of these four Midwestern farm papers. The papers kept their readers and reached out to new subscribers with low prices, club arrangements, premiums, and other inducements. Farm newspapers aimed for an audience of all different types of farmers: tenants and landowners, marginal and wealthy, diversified and cash crop. Editors claimed that they reached all of these groups. My research indicates that they were correct: farmers were the main recipients of general farm newspapers, and farmers of all types subscribed.

Farm newspapers covered both agricultural issues and social issues. Numerous editorials and articles offered recommendations concerning the character and role of the rural church, the rural school, and the farm family. These recommendations were heavily influenced by reform movements at the turn of the twentieth century: the Country Life movement, the Social Gospel, educational reform, and domestic economy. Progressive reformers 
provided both ideas and inspiration to the editors and other writers for farm newspapers. Farm papers brought reformers' instructions for a better country life into the homes of rural Midwesterners.

The editors and publishers of farm newspapers had often been born in the country but had left farming for careers in journalism. They usually moved to the cities where their papers were published. As a result, they identified more with the reformers who addressed rural audiences than with the recipients of their advice. Publishers were wealthy and were far removed from the farm, often having left it early in life. Editors attempted to keep in closer touch with farmers. But while some editors managed a farm or lived part-time in a rural neighborhood to better understand farm families, my research suggests that these efforts made little difference in their outlook. Both editors and publishers embraced Progressive ideas for the revitalization of country life. Farm newspapers thus became a key element in the communication of reform recommendations to rural Midwesterners.

Farm newspapers did not only act as conduits for reformers' ideas, however. They were different than other "agricultural institutions" such as agricultural colleges, experiment stations, rural sociologists, state departments of agriculture, and the United States Department of Agriculture. These institutions existed solely to instruct farmers in what to do. ${ }^{1}$ The farm press did more than merely present reformers' ideas to farmers. By printing letters from their readership, farm papers provided a forum for country people to respond to reformers' recommendations. While such responses must be treated carefully, they do provide glimpses of how rural Midwesterners viewed farm newspapers' advice. The interactions between farm newspapers and their readers suggest that farm newspaper editors and publishers presented a program for rural change that was only partially shared by their readers. Rural Midwesterners selectively adapted those recommendations that were in harmony with their vision of rural life.

Farm newspapers' recommended both old and new roles for the country church. They instructed rural congregants that they should make their churches the social centers of their communities and that they should cooperate with churches of other denominations. It appears that many rural Midwesterners embraced the rural church's traditional role as a center of social activity but rejected the new idea that churches of different denominations should federate. Farmers also resisted farm papers' agitation for consolidation of rural schools. Country people rejected rural school consolidation for local and traditional reasons: because they believed their oneroom schools were good enough and because they opposed transportation of their children far from home. Finally, farm women were practical in their 
response to farm newspapers' recommendations for their comfort. They adopted what they believed would lessen their work. Thus, not only were farmers' decisions about their relationship to modernity guided by tradition, they were also shaped by their vision of the future. Rural Midwesterners' vision of the future, however, did not always match the vision of farm newspapers' publishers, editors, or other staff.

These conclusions provide answers to some of the questions posed in the introduction. They help us consider why rural Midwesterners subscribed to farm newspapers and how they used the publications. More specifically, since country people rejected much of what turn-of-the-century farm newspapers promoted, why did they continue to subscribe at ever-increasing rates throughout the period?

Two possible explanations are offered by journalism studies and media theory. One is that while farm newspapers did not influence what rural Midwesterners thought, farm papers did help to determine the issues that country people thought about. This concept is called "agenda-setting." 2 Agenda-setting research has focused on the ability of news sources to direct public attention to particular political issues. ${ }^{3}$ Stuart Shulman has applied agenda-setting theory to farm newspapers, arguing that United States farm papers were a major cause of the passage of the Federal Farm Loan Act of $1916 .{ }^{4}$ In the 1990s, some scholars began to question the appropriateness of the concept, while others have broadened the meaning of the concept to include other areas in which news media may influence the thinking of their readers or viewers. ${ }^{5}$ It is plausible to think that farm newspapers directed what rural Midwesterners thought about, even though they were unable to direct actual attitudes or behavior. For this reason, even the negative responses to farm newspapers' recommendations-about rural school consolidation, for instance-reflect farm papers' power to get country people to consider an issue, regardless of the papers' ultimate ability to persuade their readership.

A second possible answer emerges from a view of mass communication as ritual rather than as transmission of information. In this understanding, publications exist not to impart information, but to represent a community's shared beliefs. As articulated by James Carey, newspapers give a reader "not pure information but a portrayal of the contending forces in the world. . . . Newspapers do not operate as a source of effects or functions but as dramatically satisfying, which is not to say pleasing, presentations of what the world at root is.... It is a presentation of reality that gives life an overall form, order and tone." Farm newspapers repeatedly provided rural Midwesterners with a description of the hardships that faced them, 
but reassured them that these hardships could be overcome. Farmers may have subscribed to and read farm newspapers less for their specific content and more for the community created by knowing others were dealing with the same situations. ${ }^{6}$

Closely tied to this understanding of communication are the actual communities built by farm newspapers. Farm newspapers may have enjoyed high circulation while presenting unpopular ideas because they provided space for community-building. Communities created in the Home Department were very satisfying to their participants. They provided rural women with an opportunity to discuss whatever they liked, including agricultural issues, domestic challenges, and neighborhood happenings. Similar communities appeared from time to time in other departments of farm newspapers when a core of correspondents wrote regularly, answered each other's questions, and discussed the same topics. The power of print to create such communities is a third way to explain farm newspapers' appeal to country people during the period.

Another answer is that rural Midwesterners may have received farm newspapers primarily for their agricultural information and not for their advice about social life at all. In their records, rural readers noted using farm newspapers' agricultural information much more than papers' recommendations for cultural transformation. In the terms of Wallaces' Farmer's motto, they were more interested in the papers' information about "Good Farming" than they were in their prescriptions for "Right Living." Some farmers may have been interested in farm papers' agricultural advice as a matter of survival, of finding ways to make enough money with the resources they had to remain in farming. For others, farm newspapers may have provided information to help them maximize the returns on their investment in land and capital. Thomas Leonard has asserted that all readers of print journalism are editors, choosing what they will read and what they will not. ${ }^{7}$ It is likely that in addition to selectively adapting the ideas communicated by farm newspapers, rural Midwesterners selectively read their papers, ignoring articles that were not of interest or with which they disagreed.

A final explanation for the popularity of farm newspapers among all levels of rural Midwesterners was farm papers' efforts to reach out to all country people. Relatively low subscription prices meant that all farmers could afford at least one farm newspaper. Some rural Midwesterners subscribed or continued to subscribe to get the premiums offered, to participate in the contests held, or to get the discounted price on other publications. Finally, some country people, like William H. Mills, worked 
to secure subscribers as a way of making extra money. All of these efforts increased the readership of general Midwestern farm newspapers, even though all of their contents might not always have been popular.

This variety of explanations for the continued popularity of Midwestern farm newspapers in the face of opposition to their social program suggests that Rural Midwesterners at the beginning of the twentieth century were complex people. As one rural historian has noted, country people may be "the last remaining human agents to be recognized as [complex] by the new social history." 8 Their reading habits were surprisingly eclectic, for their records suggest that they read books and periodicals that were aimed at vastly different audiences. Rural Midwesterners lived in the midst of demographic, economic, and social transformations during the late nineteenth and early twentieth centuries. Motivated by both tradition and the desire to change, they chose the reforms that fit in with their traditional ways of life and that offered the most hope of easing their life in the present. Country people applied these criteria to both the "Good Farming" and "Right Living" editorials and articles in Midwestern farm newspapers. Their decisions about these issues reflected their "Clear Thinking."

Because of the interaction among publishers, editors, and readers of farm newspapers, the papers themselves are an incredibly rich source of information for historians. Albert Lowther Demaree concluded his pioneering study of nineteenth century farm press by calling on historians to use them more often for information on agricultural, economic, and social developments in American history. ${ }^{9}$ Writers of the "new rural history" have increasingly turned to them for information about a variety of topics. This use is appropriate, but historians must be careful as they approach farm newspapers as evidence. They must exhibit as much "Clear Thinking" as the country people that they study.

When using farm newspapers, a historian must first consider the identity of the author of each individual article or editorial. One must not treat everything printed in a farm newspaper alike. Because the editor or publisher of the paper wrote editorials, editorials came from individuals who occupied a far different position from that of Midwestern farmers. Farmers did not write most articles either. Staff members or special authors wrote most articles and features. Special authors often were from an agricultural institution such as an agricultural college, experiment station, state department of agriculture, or the U. S. D. A. Sometime these special authors were farmers, however, so they did write with the benefit of actual farming experience. The identity of the author of a piece greatly determines how it can be used as evidence. 
It is also important to determine the identity of authors of letters. Sometimes the individual's position is given. The paper may reveal that the writer is a county school superintendent or a country pastor. The letter itself may identify the writer as the wife of a tenant farmer, or as a farmer who owns three hundred acres. Sometimes the address is helpful: if it is a large town or city, the author may have an urban background. If the address given is a rural route or a rural neighborhood or crossroads that no longer exists, the writer is often a country person. Pseudonyms were used often, and some like "Aunt Belle" make it more difficult to determine the identity of a correspondent. Others such as "A Young Farmer" or "Farmer's Wife" make it easier to identify the position the author occupies. Once again, determining if a writer actually lived on a farm is a great help in deciding how the contents of the letter can be used.

Historians may use farm newspapers for several different purposes. First, they may use farm papers to trace actual changes in agricultural practices and trends in country life. They may also study agricultural papers to see what country people thought about the changes that were occurring around them. Finally, farm newspapers can be studied as a way of tracing the influence of social movements on rural life. If a researcher is looking to farm newspapers for information about how farmers actually farmed and lived, he should consult "How We Did it Right" articles and letters. "How We Did it Right" articles often provide information in a celebratory way, so one must watch for exaggerations. Also, because editors, staff writers, and other non-farming authors often wrote these stories, their descriptions were filtered through a non-rural source. Letters often provide more useful information, for they describe exactly how an individual family farmed or dealt with a problem. Both type of source pose the problem of representativeness. "How We Did it Right" articles covered the showpieces of the agricultural world and not the mass of Midwestern farmers. It is also difficult to tell if letters represented the ideas of more than just their authors. These objections can be leveled against many social history sources, however, and historians must work with what we have.

If one wants to study the attitudes of country people, one must use letters. Articles usually promote the overall program of the farm paper itself, and editorials certainly present the vision of the editor. Therefore neither of these will give an idea of how the paper's program was received by country people. Letters are the only true source for support of assertions concerning the thoughts and attitudes of rural Midwesterners. While editors did control which letters were printed and which were not, it is clear that they provided at least some space for opinions that were different from their own. Used 
carefully, letters to the editor provide glimpses at what country people were thinking.

Finally, to study the influences of social movements on print culture or the transmission of elite reform ideas to a mass audience, a historian should look at editorials and feature articles. It is in editorials that the reform ideas of the period were turned into specific recommendations for country people. Editorials attempted to persuade their audience of the wisdom of adopting the reformers' advice. Feature articles celebrated the successes of country people that had followed their recommendations.

Historians studying farm newspapers should identify the authors of editorials, articles, and letters carefully. They should then judiciously choose the appropriate type of piece-feature article, editorial, or letter-for the research questions they are pursuing. Finally, they should communicate the identity of the author and the type of article to the reader either in the text or a footnote. Some historians have not done one or more of these steps, and have come to conclusions that are not clearly supported by their evidence.

The years between 1895 and 1920 were prosperous ones for both American farmers and the American farm press. But this "golden age" also produced great anxiety about the future of farming, especially in the Midwest. Even as life was getting demonstrably easier and better for rural Midwesterners, more and more country people were leaving for the city. Progressive reformers addressed this anxiety by recommending that country people significantly change their way of life. Midwestern farm newspapers communicated these recommendations to rural Midwesterners and allowed their readers to respond. For their part, country people accepted reformers' advice selectively, implementing those recommendations that fit in with their traditions and that they thought would improve their lot. The Midwestern agricultural press fostered the interaction between rural Midwesterners and reformers and recorded it in print. Historians today can better understand the attitudes and choices of rural people because of the tangible results of this interaction: Midwestern farm newspapers. 
Page Intentionally Left Blank 


\section{Midwestern Farm Newspapers Since the 1920 s}

The story of farm newspaper publishing since 1920 has been one of consolidation. The agricultural price slump that began that year became an agricultural depression that continued throughout the decade. As a result, many farm newspapers were sold, closed, or merged. Nationwide, the number of farm papers dropped from 405 to $384 .^{1}$ The four farm newspapers studied participated in this consolidation. In 1921, Arthur Capper bought the Journal of Agriculture, a St. Louis based paper with the longest publishing history in the state of Missouri. He merged it with the Missouri Ruralist, adopting the volume numbers of the older paper. The Ruralist became the farm newspaper with the largest circulation in Missouri. ${ }^{2}$ Also during the 1920s, three Illinois farm papers with significant circulation merged. By 1927, only the resulting Illinois Farmer remained to compete with the Prairie Farmer. ${ }^{3}$ Finally, in 1929, Dante M. Pierce sold the Iowa Homestead to the Wallace Publishing Company. Henry A. and John P. Wallace merged the Homestead with Wallaces' Farmer to become Wallaces' Farmer and Iowa Homestead. It appears that Pierce was tired of competing with the Wallaces and wanted to concentrate on a Wisconsin farm newspaper. The first issue of the combined paper appeared October 26, 1929, three days before "Black Tuesday" and the precipitous decline in stock market prices that signaled the start of the Great Depression. ${ }^{4}$

The Great Depression caused additional consolidation in the farm press. In 1931, the Prairie Farmer absorbed its last competitor, the Illinois Farmer. At the same time, declining advertising and circulation hurt the fledgling Wallaces' Farmer and Iowa Homestead. By 1932 it was clear that it could not continue publication. Because Dante M. Pierce was its major creditor, he was called in as receiver early that year. Pierce's company bought 
the paper at sheriff's sale in 1935. The number of commercial farm periodicals nationwide continued to drop from 384 in 1930 to 295 in $1945 .^{5}$

Prosperity returned to agriculture after the Second World War, and both the number of farm periodicals and their circulation climbed during the late 1940s and early 1950s. However, during the late 1950 s and 1960 s, farm newspapers suffered a crisis. Consumer advertisers pulled out of farm newspapers in favor of television, radio, and consumer magazines. Publishing costs increased, making a large circulation a liability. Publishers shifted from attempting to reach a mass audience to a targeted audience in order to better serve their advertisers. With the departure of consumer goods advertising, farm newspapers dropped their home and other non-agricultural departments in order to focus on farming information. Subscribers paid for so little of publication costs that they had little say in such decisions. ${ }^{6}$ The rural population had also begun a sharp decline. While total farm employment in 1950 was around ten million, by 1970 , it had decreased to four and a half million. General farm periodicals today are mainly monthly publications whose circulation is controlled in the interest of advertisers. For instance, if one is a general farmer in the state of Iowa, one can receive Wallaces Farmer free. If one is not a farmer, the subscription price is $\$ 21.95$ for a year. $^{7}$

Finally, the consolidation of farm newspapers into the globalized media industry accelerated in the latter half of the twentieth century. Burridge D. Butler, owner of the Prairie Farmer bought radio station WLS from the Sears Corporation in $1928 . .^{8}$ Several decades later, in July 1957, the Prairie Farmer Publishing Company purchased Wallaces' Farmer. By mid-century, however, WLS was the most lucrative part of the corporation. When American Broadcasting-Paramount Theatres, Inc. bought the radio station in 1960, the deal included the two farm newspapers. ${ }^{9}$ The papers were subsequently passed along in a chain of media buyouts during the last decades of the century:

In 1986, Capital Cities Communications acquired the American Broadcasting Company ( $\mathrm{ABC}$ ), which then became known as CAP Cities/ABC. In February 1996 the Walt Disney Company purchased Capital Cities/ABC. Most recently, (June 1997) the Disney Company sold the Agricultural Publishing Group of ABC, Inc., which includes Wallaces Farmer, to Rural Press Limited, New South Wales, Australia. ${ }^{10}$

When I first did research for this project in 2001, Rural Press Limited published thirty-five state-based farm newspapers in the United States. In 2004, the number of publications had been reduced to eighteen. Some still are targeted at states, including Wallaces Farmer, Prairie Farmer, and the Missouri Ruralist. Others are now regional. Rural Press Limited's U. S. subsidiary, the 
Farm Progress Companies, handles subscriptions for all the papers from their office in Carol Stream, Illinois. Each publication also maintains a local editorial office. Table 18 gives the circulation of the three papers compared to census figures for 2003. ${ }^{11}$

Today, general monthly farm magazines compete with a number of different sources of information for farmers. One reference work lists two two hundred and sixty different magazines and newspapers aimed specifically at a farm or agricultural market. This number includes publications put out by publishers and farm organizations such as the American Farm Bureau Association and its state affiliates. The number is less than there have been at any time since $1885 .{ }^{12}$ Corporations that serve the farm market, such as John Deere and Pioneer Seeds also publish elaborate magazines and newspapers. A number of these print publications have websites on the Internet, and the World Wide Web is the home of a number of information sources for farmers that do not have print counterparts. As they did in the early twentieth century, rural Midwesterners have a number of places to turn to for agricultural information. Unlike that period, however, farm papers have lost their place of dominance in the market for farm information.

Table 18. Circulation Figures for Midwestern Farm Newspapers Compared to Census Figures for Number of Farms and Total Population

\begin{tabular}{|c|c|c|c|}
\hline Year & $\begin{array}{l}\text { Total } \\
\text { Population } \\
\text { of Iowa }\end{array}$ & $\begin{array}{l}\text { Number of } \\
\text { Farms } \\
\text { in Iowa }\end{array}$ & $\begin{array}{l}\text { Circulation of } \\
\text { Wallaces Farmer }\end{array}$ \\
\hline 2003 & $2,944,062$ & 90,000 & 85,000 \\
\hline Year & $\begin{array}{l}\text { Total } \\
\text { Population } \\
\text { of Illinois }\end{array}$ & $\begin{array}{l}\text { Number of } \\
\text { Farms } \\
\text { in Illinois }\end{array}$ & $\begin{array}{l}\text { Circulation of } \\
\text { Prairie Farmer }\end{array}$ \\
\hline 2003 & $12,653,544$ & 73,000 & 59,000 \\
\hline Year & $\begin{array}{l}\text { Total } \\
\text { Population } \\
\text { of Missouri }\end{array}$ & $\begin{array}{l}\text { Number of } \\
\text { Farms } \\
\text { in Missouri }\end{array}$ & $\begin{array}{l}\text { Circulation of } \\
\text { Missouri Ruralist }\end{array}$ \\
\hline 2003 & $5,704,484$ & 106,000 & 35,000 \\
\hline
\end{tabular}

Sources: Circulation Figures: Bowker's News Media Directory, 54th ed. (New Providence, NJ: Bowker, 2004), vol. 2, 5-12 to 5-14. Census figures: Economic Research Service, United States Department of Agriculture, "Illinois Fact Sheet," available at http://www.ers.usda.gov/ statefacts/IL.htm, internet, accessed 10 October 2004; "Iowa Fact Sheet," http://www.ers. usda.gov/statefacts/IA.htm, internet, accessed 10 October 2004; "Missouri Fact Sheet," http://www.ers.usda.gov/statefacts/MO.htm, internet, accessed 10 October 2004. 
Page Intentionally Left Blank 


\section{Notes}

\section{NOTES TO INTRODUCTION}

1. Walter Nugent, Structures of American Social History (Bloomington: Indiana University Press, 1981), 87-120; Richard Hofstadter, The Age of Reform: From Bryan to FDR (New York: Vintage, 1955), 23.

2. Hal S. Barron, Mixed Harvest: The Second Great Transformation in the Rural North, 1870-1930 (Chapel Hill: University of North Carolina Press, 1997), 10-12; Alfred D. Chandler, Jr., The Visible Hand: The Managerial Revolution in American Business (Cambridge: Harvard University Press, 1977); Louis Galambos, "The Emerging Organizational Synthesis in Modern American History," Business History Review 44(1970): 279-290 and "Technology, Political Economy, and Professionalization: Central Themes of the Organizational Synthesis," Business History Review 57(1983): 471-493; Robert Wiebe, The Search for Order, 1877-1920 (New York: Hill and Wang, 1967); Richard Ohmann, Selling Culture: Magazines, Markets and Class at the Turn of the Century (New York: Verso, 1996); T. J. Jackson-Lears, Fables of Abundance: A Cultural History of Advertising in America (New York: Basic Books, 1994).

3. Hal S. Barron, Mixed Harvest; Mary Neth, Preserving the Family Farm: Women, Community and the Foundations of Agribusiness in the Midwest, 1900-1940 (Baltimore: The Johns Hopkins University Press, 1995); Ronald R. Kline, Consumers in the Country: Technology and Social Change in Rural America (Baltimore: Johns Hopkins University Press, 2000).

4. R. Douglas Hurt, American Agriculture: a Brief History (Ames: Iowa State University Press, 1994), 165-286; David B. Danbom, Born in the Country: a History of Rural America (Baltimore: Johns Hopkins University Press, 1995), 132-186; James F. Evans and Rodolfo N. Salcedo, Communications in Agriculture: the American Farm Press (Ames: Iowa State University Press, 1974), 6-29.

5. The most famous statement of this narrative is Wiebe, The Search for Order. For an early critique of modernization theory, see Thomas Bender, Community and Social Change in America (New Brunswick: Rutgers 
University Press, 1978). For a consideration of Wiebe's influence, attraction, and shortcomings, see Kenneth Cmiel, "Destiny and Amnesia: The Vision of Modernity in Robert Wiebe's The Search for Order," Reviews in American History 21(1993): 352-368.

6. David B. Danbom, The Resisted Revolution: Urban America and the Industrialization of Agriculture, 1900-1930 (Ames: Iowa State University Press, 1979); William L. Bowers, The Country Life Movement in America: 1900-1920 (Port Washington, N.Y.: Kennikat Pres, 1974).

7. On the new rural history, see Robert P. Swierenga, “The New Rural History: Defining the Parameters" Great Plains Quarterly 1(4) (Fall 1981): 212 and "Theoretical Perspectives on the New Rural History: From Environmentalism to Modernization" Agricultural History 56(3) (July 1982): 495-502. The most sweeping synthesis of the New Rural History is Barron, Mixed Harvest; the field's only comprehensive narrative is Danbom, Born in the Country.

8. C. Beaman Smith and H. K. Atwood, "The Relation of Agricultural Extension Agencies to Farm Practices." In Miscellaneous Papers, U. S. Department of Agriculture Bureau of Plant Industry Circular No. 117 (Washington, D. C.: Government Printing Office, 1913), 25. This report is considered in detail in Chapter Four.

9. Evans and Salcedo, 171; Arthur F. Raper, A Graphic Presentation of Rural Trends (Washington, D. C.: Extension Service and Bureau of Agricultural Economics, United States Department of Agriculture, 1952), 4.

10. This celebratory stance is taken by Gilbert M. Tucker, American Agricultural Periodicals: An Historical Sketch (Albany: Privately Printed, 1909), William Edward Ogilvie, Pioneer Agricultural Journalists: Brief Biographical Sketches of Some of the Early Editors in the Field of Agricultural Journalism (Chicago: Arthur J. Leonard, 1927), and some of the authors in Alan Fusonie and Leila Moran, eds, Agricultural Literature: Proud Heritage-Future Promise, A Bicentennial Symposium, September 24-26, 1975 (Washington, DC: Associates of the National Agricultural Library and the Graduate School Press, United States Department of Agriculture, 1977).

11. Mary Neth is one exception. She identifies farm newspapers as "agricultural institutions," along with rural sociologists and Country Life reformers. Neth, Preserving the Family Farm, 97-121.

12. David Vaught, conversation with author, 5 August 2000. See Adam Ward Rome, “American Farmers as Entrepreneurs, 1870-1900," Agricultural History 56(4)(October 1982): 37-49 for an example of an unsophisticated use of farm newspapers.

13. Danbom, Born in the Country, 132-186; Hurt, American Agriculture, 221-277.

14. Report of the Country Life Commission, Senate Document No. 705, 60th Congress, 2d Session (Washington, D. C.: Government Publishing Office, 1909), 60.

15. Report of the Country Life Commission, 13-19, 29-47; Clayton Ellsworth, “Theodore Roosevelt's Country Life Commission," Agricultural History 34 
(Fall 1960): 155-172; Scott J. Peters and Paul A. Morgan, "The Country Life Commission: Reconsidering a Milestone in American Agricultural History," Agricultural History 78(3)(Summer 2004): 289-316;

16. Bowers, The Country Life Movement in America, 86-102.

17. Neth, Preserving the Family Farm, 97-110; David B. Danbom, "Rural Education Reform and the Country Life Movement, 1900-1920," Agricultural History 53(2)(April 1979): 462-463; Bowers, The Country Life Movement in America, 30-45; Rcynolds, There Goes the Neighborhood: Rural School Consolidation at the Grass Roots in Early Twentieth Century Iowa (Iowa City: University of Iowa Press, 1999), 34-45; Paul Theobald, Call School: Rural Education in the Midwest to 1918 (Carbondale: Southern Illinois University Press, 1995); Grant McConnell, The Decline of Agrarian Democracy (Berkeley: University of California Press, 1953), 20-43; Peters and Morgan, 297-301.

18. Kenneth Wheeler, "The Apex of Midwestern Culture?: Recent Historiography and Reinterpretations of the Midwest," paper presented at the Organization of American Historians Midwestern Regional Conference, 4 August 2000, 6; David M. Kennedy, Over Here: The First World War and American Society (Oxford: Oxford University Press, 1980), 92; Arthur S. Link and Richard L. McCormick, Progressivism (Wheeling, Illinois: Harland Davidson, 1983), 96-104.

19. Tucker, American Agricultural Periodicals; Albert Lowther Demaree, The American Agricultural Press, 1819-1860 (New York: Columbia University Press, 1941); Evans and Salcedo, 170, 178.

20. Evans and Salcedo, $x$.

21. David R. Cassady, "The Content of the Rural Weekly Press in Illinois in 1882 " (Ph. D. diss., University of Iowa, 1980); Gladys Talcott Rife, "Iowa's Rural Women's Columnists, Especially of the Fifties: Their Cultural and Historical Import in a Comparative Context" (Ph. D. diss., University of Iowa, 1988).

22. Jean Folkerts, "Functions of the Reform Press," Journalism History 12(1) (Spring 1985): 22-25; Seymour Lutzky, “The Reform Editors and their Press," (Ph. D. diss., University of Iowa, 1951).

23. “Wallaces' Farmer Outside Iowa," WF 23 December 1904, 1601.

24. These classifications are adapted from Jack Van Derhoof, "Eastern and Mid-Western Agricultural Journalism, 1860-1900" (Ph.D. diss., Columbia University, 1951), 14-17.

25. Charles Reagan Wilson, ed., The New Regionalism (Jackson: University Press of Mississippi, 1998);

26. Andrew R. L. Cayton and Peter S. Onuf, The Midwest and the Nation: Rethinking the History of an American Region (Bloomington: Indiana University Press, 1990); James R. Shortridge, The Middle West: Its Meaning in American Culture (Lawrence: University Press of Kansas, 1989); James Madison, ed., Heartland: Comparative Histories of the Midwestern States (Bloomington: Indiana University Press, 1988); Ginette Aley, “'Knotted Together Like Roots in the Darkness': Rural Midwestern Women and Region-A Bibliographic Guide," Agricultural 
History 77(3)(Summer 2003): 453-458; Kenneth Wheeler, "The Apex of Midwestern Culture?"; Andrew R. L. Cayton and Susan E. Gray, "The Story of the Midwest: An Introduction," in Cayton and Gray, eds., The American Midwest: Essays on Regional History (Bloomington: Indiana University Press, 2001): 1-26.

27. My use of the term "Lower Midwest" is somewhat different than Cayton and Gray's.

28. Christopher P. Wilson uses a small selection of important magazines to study the turn-of-the-century magazine in his "The Rhetoric of Consumption: Mass-Market Magazines and the Demise of the Gentle Reader, 1880-1920" in Richard Wightman Fox and T. J. Jackson Lears, eds., The Culture of Consumption: Critical Essays in American History, 1880-1980 (New York: Pantheon Books, 1983): 39-64.

29. Richard T. Farrell, in a 1977 article, presented the results of content analyses of five different farm newspapers representing three different regions of the country. On the basis of statistical analyses, he concluded that a small sample of papers can be seen as representative of a region's farm newspaper output. "Advice to Farmers: The Content of Agricultural Newspapers, 1860-1910," Agricultural History 51(1)(January 1977): 209-217.

30. Gerald W. Creed and Barbara Ching give an argument for the consideration of place in "Recognizing Rusticity: Identity and the Power of Place," in Knowing Your Place: Rural Identity and Cultural Hierarchy, edited by Barbara Ching and Gerald W. Creed, (New York: Routledge, 1997), 1-38.

31. "To Check Rural Population Loss," MR 13 April 1912, 4.

32. Robert Swierenga, "The Little White Church: Religion in Rural America," Agricultural History 71(4)(Fall 1997): 415-441; D. G. Hart, "The Failure of American Religious History," The Journal of the Historical Society 1(1)(Spring 2000): 1-27; Paul Boyer, "In Search of the Fourth ' $R$ ': The Treatment of Religion in American History Textbooks and Survey Courses," The History Teacher 29(2)(February 1996): 210-211; Wilfred M. McClay, "Teaching Religion in American Schools and Colleges: Some Thoughts for the 21st Century," Historically Speaking 3(2)(November 2001): 13-17.

33. See David Vaught, "State of the Art-Rural History, or Why Is There No Rural History of California," Agricultural History 74(4)(Fall 2000): 762-764.

34. David B. Danbom, "The Professors and the Plowmen in American History Today," Wisconsin Magazine of History 69(2)(Winter 1985-86): 106-128. See also Jon Lauck, “'The Silent Artillery of Time': Understanding Social Change in the Rural Midwest," Great Plains Quarterly 19(4)(Fall 1999): 245-256.

\section{NOTES TO CHAPTER ONE}

1. These terms are from "More First-Class Papers," WF 22 November 1907, 1359.

2. "The Never-Stop Papers' Annual Shearing," WF 20 December 1907, 1487. 
3. "How to Stop a Paper," WF 17 December 1897, 4; "Stops When the Time is Out," WF 4 November 1898, 830; "In the Hands of Its Readers," WF 12 January 1900, 40; "How to Stop a Paper," WF 5 October 1900, 973; "The Farmer and His Reading Matter," WF 29 April 1904, 601; "Select Your Own Reading Matter," WF 10 November 1905, 1326; "The NeverStop Papers' Annual Shearing," WF 20 December 1907, 1487; "NeverStop Papers," 9 February 1912, 7.

4. Evans and Salcedo, Communications in Agriculture, 3-10.

5. Sociologists of journalism examine news publications using institutional, organizational, and individual levels of analysis. In this chapter, I explore the institutional level by surveying national trends in farm newspaper publication and distribution and the organizational level by examining the history and characteristics of the four individual farm newspapers. Chapter two will examine the individual level by describing the identities of the four papers' publishers and editors. Dan Berkowitz, ed. Social Meanings of News: A Text-Reader (Thousand Oaks, Ca.: Sage Publications, 1997), xii-xiv, 3-5.

6. Evans and Salcedo, 3-5, 170-171, 175, 179.

7. Evans and Salcedo, 6-10; Danbom, Born in the Country, 161-184.

8. One such notice, sent to Isaac N. Carr of Washington County, Iowa, was saved in his papers. Iowa Homestead Subscription Notice, Box 6, Folder 12, Isaac N. Carr Papers, SHSI-IC.

9. Van Derhoof, “Eastern and Mid-Western Agricultural Journalism," 71-83. Van Derhoof asserts that the most important of these methods was providing a good product.

10. Evans and Salcedo, 14-20, 26-27; Smith and Atwood, "The Relation of Agricultural Extension Agencies to Farm Practices."

11. Van Derhoof, 95-102. He admits that Henry Wallace of Wallaces' Farmer did not fit his description, as that paper remained intensely personal until Wallace's death in 1916.

12. Frank Luther Mott, American Journalism: A History, 1690-1960, 3rd Ed. (New York: Macmillan, 1962), 715; James F. Evans, Prairie Farmer and WLS: The Burridge D. Butler Years (Urbana: University of Illinois, 1969), 72-73; Charles O. Bennett, Integrity in a Changing World: Seventy-Five Years of Industry Self-Regulation Through the Audit Bureau of Circulations (Chicago: Audit Bureau of Circulations and Mobium Press, 1989), 1-17.

13. C. R. F. Smith, “The Iowa Homestead," The Palimpsest 11(6)(June 1930): 229-241; Van Derhoof, 378-397; Gerald LeRoy Seaman, "A History of Some Early Iowa Farm Journals (before 1900)" (M. S. thesis, Iowa State College, 1942), 19-42; Frank Luther Mott, "Farm, Stock, and Dairy Journals," The Palimpsest 44(8)(August 1963): 343-348; Donald R. Murphy, "The Centennial of a Farm Paper," The Palimpsest 37(9)(September 1956): 449-469.

14. Richard S. Kirkendall, Uncle Henry: a Documentary Profile of the First Henry Wallace (Ames: Iowa State University Press, 1993), 91-101; Murphy, "Centennial of a Farm Paper," 465-466; "A Word Personal," IH 1 February 189.5, 5; Henry Wallace, “A Word Personal," WF 15 February 1895, 6-7. 
15. N. W. Ayer \& Son's American Newspaper Annual (Philadelphia: N. W. Ayer \& Son, 1895, 1900).

16. Ayer, 1900, 1905; IH 14 September 1905, 1302; Murphy, “Centennial of a Farm Paper," 467.

17. Ayer, 1920; James M. Pierce, “A Personal Statement," IH 6 February 1913, 268; James M. Pierce, “A Year Ago and Now,” IH 5 February 1914, 284; James M. Pierce, "The Splendid War Work of James Atkinson," IH 22 August 1918, 1515; Dante M. Picrce, "James Melville Pierce," IH 4 November 1920, 3039; Dante M. Pierce, “The Iowa Homestead Will Go On Unchanged," IH 11 November 1920, 3087.

18. Demaree, American Agricultural Press, 376-380; Richard Bardolph, Agricultural Literature and the Early Illinois Farmer (Urbana: University of Illinois Press, 1948), 97-98; John T. Schlebecker and Andrew W. Hopkins, A History of Dairy Journalism in the United States, 1810-1950 (Madison: University of Wisconsin Press, 1957), 15-18; “A Brief History of Prairie Farmer," (Decatur, IL: n.d.), 2-3, a history sent on request by Farm Progress Companies, the current parent company of Prairie Farmer.

19. James F. Evans, Prairie Farmer and WLS, 43.

20. Van Derhoof, 272-285; Evans, Prairie Farmer and WLS, 43-51.

21. "Seventy Years of Prairie Farmer," PF 15 November 1911, 5; "Jonathan Perriam," PF 1 January 1912; 10. Ayer, 1895, 1900, 1905.

22. Van Derhoof, 282; Ayer, 1895, 1900, 1905.

23. "A Change of Policy," PF 1 January 1908, 2; "Change in Price of Subscription," PF 1 June 1908, 3.

24. “Every other Saturday," PF 15 December 1914, 776; Ayer, 1920; Evans, Prairie Farmer and WLS, 62-78, 125-130.

25. WF 6 September 1895. As well as lengthening the title, the change moved the apostrophe. "Notice of Removal," WF 27 December 1895, 2; "Change of Location," 3 January 1896, 2.

26. WF 9 December $1898,1$.

27. Ayer, 1895, 1905; Arthur T. Thompson, "Wallaces' Farmer," The Palimpsest 11(6)(June 1930): 242-248; Murphy, "Centennial of a Farm Paper," 470-472; Mott, “Farm, Stock, and Dairy Journals," 347-348; Kirkendall, 100-108; Schlebecker and Hopkins, 74-76.

28. Ayer, 1920; Kirkendall, 208-212, 218-222; Edward L. Schapsmeier and Frederick H. Schapsmeier, “The Wallaces and Their Farm Paper: a Story of Agrarian Leadership" Journalism Quarterly 44(2)(1967): 289-296.

29. Billy Clyde Brantley, "History of the Missouri Ruralist, 1902 through 1955" (M. A. thesis, University of Missouri-Columbia, 1958), 10-57.

30. Brantley, 34-50, 58-62; Homer E. Socolofsky, "The Development of the Capper Farm Press," Agricultural History 31(4)(October 1957): 37-41; "Change of Ownership," MR 30 June 1910, 6; W. E. Cundiff, "Buys Another Paper," MR 10 December 1910, 4; “A New Editor for the Ruralist," MR 8 June 1912, 4; “Mr. Nelson Leaves,” MR 27 September 1913, 5 .

31. John F. Case, "For a Better Ruralist," MR 29 November 1913, 4; Ayer, 1910, 1920. 
32. Evans and Salcedo, 10-12; Lisle Leslie Longsdorf, “The Agricultural Press of America, 1850-1900" (Masters Thesis, University of Wisconsin, 1926), 60-64; WF 3 January 1913, 15; James M. Pierce, “The Iowa Homestead and Its Readers," IH 20 December 1917, 1975; "Fifty Cents a Year," MR 16 March 1905, 8; “Change in Price of Subscription," PF 1 June 1908, 3.

33. MR 1 December 1904, 9; “Try It and Prove It," MR 4 January 1906, 6.

34. PF 15 July 1908,24 ; WF 3 January $1913,15$.

35. "Please Pay the Club Raiser," WF 17 February 1911, 274; "That Blessed Club Raiser," WF 3 November 1911, 1514; "Helping us Grow," WF 30 November 1917, 1617; "Special Announcement to Club-Raisers," PF 2 November 1895, 3; "Your Neighbor Will Thank You for the Opportunity for Joining Your Club," PF 14 Jan 1899, 3; "Blocks-Of-Two," MR 12 November 1903, 8; William H. Mills Papers, ISU.

36. Van Derhoof, 72.

37. PF 26 December 1896, 9; PF 2 January 1897, 11; Ayer, 1900; IH 10 January 1896, 4; IH 3 January 1918, 23.

38. PF 5 December 1896, 15; PF 12 December 1896, 15; MR 26 November $1903,9$.

39. PF 26 December 1896, 16; MR 5 November 1903, 3; MR 7 January 1904, 3; $M R \quad 9$ June 1910, 16; MR 27 September 1913, 12; “The (Farm Boy' Letters in Book Form," WF 8 October 1897, 4.

40. PF 26 December 1896, 16; WF 13 November 1896, 7.

41. WF 4 January $1907,5$.

42. MR 6 January 1912, 23.

43. “Our Guessing Contest," MR 25 June 1903, 8; MR 25 June 1903, 9; MR 3 December 1903, 9; “The Prize Winners," MR 28 January 1904, 8; “The Prize Winners," MR 7 July 1904, 8; MR 14 July 1904, 9; “Those Prize Winners," MR 23 February 1905, 10. Thomas C. Leonard, News for All: America's Coming of Age with the Press (New York: Oxford University Press, 1995), 185-187.

44. Brantley, 74.

45. Van Derhoof, 77.

46. "Beware of Fake Subscription Solicitors," WF 15 February 1918, 290; "How the Subscription Faker Works the Farmer," PF 23 September 1916, 743.

47. PF 19 August $1899,1,3$. This ad was repeated many times. A September editorial stated that fair agents could make between three and ten dollars a day, but this claim was not repeated. "Big Wages Made," PF 9 September 1899, 2-3.

48. PF 4 November $1899,3$.

49. "Subscribers at the Fairs," WF 10 July 1896, 3; "Agents at Fairs Wanted," IH 13 August 1897, 5.

50. Leonard, News for All, 33-64.

51. PF 2 February 1905,6 , emphasis in original.

52. "Postal Rulings and the Press," PF 15 January 1908, 3; E. E. Codding, "Postmaster's Official Notice," MR 26 March 1908, 8; "Stop Notice Unnecessary," MR 25 February 1909, 10. 
53. IH 2 January $1919,4$.

54. "Cheap Grain, Cheap Reading," WF 1 November 1895, 4.

55. "The Teachings of Agricultural Papers," WF 4 March 1910, 2; "To Our Readers," WF 5 October 1900, 968.

56. “Using a Farm Paper Makes it More Useful," MR 15 April 1911, 4; MR 5 March 1908, 8.

57. "Dignity of Farm Journalism," IH 15 September 1904, 1250; "What Can a Farm Papcr Do?” IH 1 February 1913, 12.

58. "A Paper for Western Farmers," PF 6 January 1900, 1.

59. “Trans-Missouri Readers," WF 23 February 1900, 190; "Farm Papers for the Kansas Farmer," WF 7 December 1900, 1199; "A Chat with Missouri Subscribers," WF 4 July 1902, 910; "Wallaces' Farmer Outside Iowa," 23 December 1904, 1601. In 1910 the subtitle was changed to "A Weekly Journal for Thinking Farmers." WF 7 January 1910, 1.

60. M. V. Carroll, "Introductory," MR 16 October 1902, 8; "Practical Papers," MR 8 January 1903, 8.

61. "The Publisher's Corner," IH 2 July 1908, 1062; “The Experience Meeting," IH 14 January 1915, 60-61.

62. "Uncle Sam's Best Counties," PF 15 April 1914, 324; "A Real Farm Paper," PF 15 December 1914, 8; "Agricultural Papers Outside their Own State," WF 10 March 1911, 438.

63. Wallaces' Farmer and the Iowa Homestead did clash over silver in 1896, but articles were about the issue, not the presidential candidates. "Silver and the Farmer," WF 4 Sept 1896, 11 Sept 1896, 18 Sept 1896, 25 Sept 1896, 2 Oct 1896, 9 Oct 1896, 16 Oct 1896, 23 Oct 1896, 30 Oct, 1896; Joel Kunze, "Shameful Venality: The Pierce-Wallace Controversy and the Election of 1896," The Palimpsest 71(1)(1990): 2-11.

64. "Personality in Newspapers," WF 29 March 1895, 4; "A Paper With an Editor," WF 10 July $1896,3$.

65. IH 4 September 1913, 5; "A Regular Feature," IH 22 March 1917, 4. Pierce's editorials will be discussed in more detail in Chapter Two.

66. “Good Farming, Clear Thinking, Right Living," WF, 7 January 1910.

67. The Iowa Homestead, "A Vital Interest Problem for the Farmer," 1911?. Pamphlet in William H. Mills Papers, ISU. The Mills Papers were not processed when I looked at them.

68. Danbom, Born in the Country, 149-154, 161-184.

69. PF 15 September 1910, 19.

70. “Our Serial Story,” WF 22 November 1912, 1651.

71. IH 10 December 1914, 29; IH 12 December 1918, 10; MR 5 November 1915,5 .

72. Van Derhoof, 81-82.

73. "Special Farmers' Institute Edition," supplement to IH 5 January 1899.

74. "Change in Institute Edition," IH 3 March 1904, 8.

75. “The Experience Meeting," IH 4 December 1913, 1951; “The Experience Meeting," IH 14 January 1915, 60-61. More on school reform in Chapter Six.

76. "Little Editorials By Our Readers," PF 15 March 1914, 8; "Ideas and Experiences from Prairie Farmer Readers," PF 18 November 1916, 4; “Our 
Readers' Editorial Page," PF 5 October 1918, 12; “Things the People Say," MR 5 December 1913, 5; “Around the Ruralist Family Table," MR 5 January $1914,5$.

77. Ellen Gruber Garvey, The Adman in the Parlor: Magazines and the Gendering of Consumer Culture, 1880s to 1910s (New York: Oxford University Press, 1996); Michael Denning, Mechanic Accents: Dime Novels and Working-Class Culture in America, Rev. ed. (London: Verso, 1998, first published 1987); Leonard, News For All; Joan Shelley Rubin, "What is the History of the History of Books?" Journal of American History 90(2)(September 2003): 555-575; Jonathan Rose, “Arriving at a History of Reading," Historically Speaking, January 2004, 36-39.

78. Joanne Passet uses letters to the editor extensively to track reader response in Sex Radicals and the Quest for Women's Equality (Urbana: University of Illinois Press, 2003).

79. Longsdorf, 60-64.

\section{NOTES TO CHAPTER TWO}

1. Mark Twain, "Memoranda: How I Edited an Agricultural Paper Once," The Galaxy, July 1870, 133-135, quote from p. 135.

2. Albert Bigelow Paine, Mark Twain: A Biography, the Personal and Literary Life of Samuel Langhorne Clemens (New York: Harper, 1920), vol. 1, 403.

3. Twain, "Memoranda," 135. Emphasis in original. The piece also was published in the Prairie Farmer in 1876, slightly edited, PF 8 April 1876, 118. The Missouri Ruralist, in a 1912 article about the Mark Twain home in Hannibal, related parts of the story as if they had actually happened. Harry W. Graham, “The Mark Twain Home," MR 25 May 1912, 6.

4. Warren Breed, "Social Control in the Newsroom: A Functional Analysis" in Dan Berkowitz, ed., Social Meanings of News, 107-122.

5. James M. Pierce, “The Country Editor," IH 27 November 1913, 1910; James M. Pierce, “The Farm Boy's Opportunities," IH 5 February 1914, 286; James M. Pierce, “The Country Newspaper," IH 8 April 1915, 763; James M. Pierce, “Our Debt to the Sunday School," IH 10 May 1917, 839; James M. Pierce, "For a Third of a Century," IH 10 January 1918, 51; Seaman, "A History of Some Early Iowa Farm Journals," 38.

6. James M. Pierce, "For a Third of a Century," IH 10 January 1918, 51.

7. Smith, "The Iowa Homestead," 232-234; Van Derhoof, "Eastern and Mid-Western Agricultural Journalism," 384-387; Murphy, “The Centennial of a Farm Paper," 464-466; Seaman, 37-38.

8. Smith, "The Iowa Homestead," 238; Murphy, "The Centennial of a Farm Paper," 467. In citing "Publisher's Views" pieces, I have given Pierce as the author.

9. Smith, "The Iowa Homestead," 238-341; Murphy, “The Centennial of a Farm Paper," 466-469; Dante M. Pierce, "The Iowa Homestead Will Go On Unchanged," IH 11 November 1920, 3087.

10. Evans, Prairie Farmer and WLS, 18-27. 
11. Evans, Prairie Farmer and WLS, 29-41; James F. Evans, "Clover Leaf: The Good Luck Chain, 1899-1933," Journalism Quarterly 46(Autumn 1969): 482-491.

12. Evans, Prairie Farmer and WLS, 62-78.

13. Brantley, "History of the Missouri Ruralist," 10-57.

14. Brantley, 58-60; Homer E. Socolofsky, Arthur Capper: Publisher, Politician, and Philanthropist (Lawrence: University Press of Kansas, 1962), 1-40.

15. Socolofsky, Arthur Capper, 53-62.

16. Brantley, 49-50, 58-62; Socolofsky, "The Development of the Capper Farm Press," 37-41; "Change of Ownership," MR 30 June 1910, 6; MR 9 July 1910, 1, 3; W. E. Cundiff, "Buys Another Paper," MR 10 December 1910, 4; "A New Editor for the Ruralist," $M R 8$ June 1912, 4; “Mr. Nelson Leaves," MR 27 September 1913, 5; John F. Case, "A Greeting," MR 4 October 1913, 5.

17. Wallace attended Geneva Hall in Northwood, Ohio, from 1856 to 1857 (now Geneva College, Beaver Falls, Pennsylvania) and Jefferson College in Washington, Pennsylvania from 1857 to 1859 (now Washington and Jefferson College), the United Presbyterian Theological Seminary in Allegheny, Pennsylvania from 1859 to 1860 (now Pittsburgh Theological Seminary), and Monmouth Seminary in Monmouth, Illinois from 1860 to 1863.

18. Biographical works on Henry Wallace include Kirkendall, Uncle Henry; Russell Lord, The Wallaces of Iowa (Boston: Houghton-Mifflin, 1947); Henry Wallace, Uncle Henry's Own Story of His Life: Personal Reminiscences, 3 vol., (Des Moines: Wallace Publishing, 1917-1919; and Harriet Wallace Ashby, "Uncle Henry Wallace," typescript biography, Papers of Henry Wallace, UI.

19. Michael E. Teller, The Tuberculosis Movement: a Public Health Crusade in the Progressive Era (Westport, CT: Greenwood Press, 1988). Henry Wallace, "Sixty Years of Farming," WF 5 January 1906, 4. Given the combative personality Wallace showed later in life, one wonders if the story of his leaving the pastorate for health reasons might be a cover for difficulties getting along with congregants.

20. James Wilson later served as United States Secretary of Agriculture from 1897 to 1913; Seaman Knapp became active in the U. S. D. A.'s extension program in the South in the early twentieth century. Hurt, American Agriculture, 189-194, 255-256.

21. Henry Wallace, "In Search of the Granger's Cow," WF 9 March 1906, 332; Henry Wallace, "How I Came to be an Agricultural Editor," WF 21 January 1919, 252; Thompson, “Wallaces' Farmer," 242-3; Murphy, 460; Mott, "Farm, Stock, and Dairy Journals," 345.

22. Thompson, 246; Murphy, 466.

23. Kirkendall, 208-212, 218-222.

24. Socolofsky, Arthur Capper, 87-105, 126-134, 145-186; Evans, Prairie Farmer and WLS, 205-248; 1915 Iowa State Census; S. Morgan Friedman, “The Inflation Calculator," http://www.westegg.com/inflation/; internet; accessed 4 November 2004. 
25. Evans, Prairie Farmer and WLS, 60.

26. Iowa Federal Census.

27. C. V. Gregory, "Prolonging Life with Ice-Cream," The World To-Day 20(May 1911): 611-612; Clifford V. Gregory, “The Truth About the Farmer," Collier's 47(July 8, 1911): 20.

28. Burridge D. Butler, "Our New Editor," PF 1 June 1911, 12; Evans, Prairie Farmer and WLS, 60-61, 125-130; Clifford V. Gregory, The Good Old Days (Amcrican Farm Bureau Federation, 1938).

29. Brantley, 79.

30. Brantley, 76-82; “Mr. Nelson Leaves," MR 27 September 1913, 5; John F. Case, "A Greeting," MR 4 October 1913, 5.

31. John F. Case, “The Editor Buys a Farm," MR 5 September 1915, 4.

32. Brantley, 84-85; John F. Case, "From the Farm to You," MR 20 May 1916, 4; John F. Case, "I'm On The Firing Line," MR 20 June 1917, 3; John F. Case, "We've Moved to St. Louis," MR 20 October 1917, 3; John F. Case, "Back to the Firing Line, "MR 20 May 1918, 4; John F. Case, "Back to the Office Again,” MR 5 October 1919, 4; John F. Case, “At Shady Lawn Farm Home," MR 5 June 1920, 12.

33. Iowa State College of Agriculture and the Mechanic Arts Catalog (Ames: Iowa State College, 1898-1901); 1900 Iowa Federal Census; 1915 Iowa State Census; Murphy, 467; James M. Pierce, "The Splendid War Work of James Atkinson," IH 22 August 1918, 1515.

34. Iowa State Census; S. Morgan Friedman, "The Inflation Calculator," http://www.westegg.com/inflation/; internet; accessed 4 November 2004. Gregory worked for Wallaces' Farmer and Iowa Homestead; the papers had merged in 1929. See the Epilogue for more about the depression.

35. Bowers, The Country Life Movement in America, 4.

\section{NOTES TO CHAPTER THREE}

1. This title is patterned after Donald R. Murphy's What Farmers Read and Like: A Record of Experiments with Readership on Wallaces Farmer and Wisconsin Agriculturist, 1938-1961 (Ames: Iowa State University Press, 1962). This chapter presents a picture of what farmers read a generation earlier.

2. Mame E. Weller, letter to the "Hearts and Homes" department, WF 29 June 1900, 666.

3. Asa Markel, letter to PF 13 Jan 1900, 1.

4. William J. Gilmore, Reading Becomes a Necessity of Life: Material and Cultural Life in Rural New England, 1780-1835 (Knoxville: University of Tennessee Press, 1989).

5. Joycc Appleby, Inheriting the Revolution: The First Generation of Americans (Cambridge: Harvard University Press, 2000), 140-141.

6. John Campbell Bailey, diary entry for 15 January 1896, Box 1, Folder 11, John Campbell Bailey Diaries, ISHL; Bailey's diaries are actually owned by the Rock Island Historical Society; a copy is kept at the Illinois State Historical library. N. W. Ayer \& Son's American Newspaper Annual (Philadelphia: N. W. Ayer \& Son, 1895), hereafter, Ayer 1895. 
7. Bailey, diary entries for 26 February, 27 February, 23 October, 11 December 1896, John Campbell Bailey Diaries, ISHL; Ayer 1895.

8. The Past and Present of Rock Island County (Chicago: H. F. Kett and Company, 1877); Historical Encyclopedia of Illinois and History of Rock Island County (Chicago: Munsell Publishing Company, 1914), volume 2, 1009.

9. For more details about my sources and research methodology, see John J. Fry, "Reading, Reform, and Rural Change: The American Farm Press, 1895-1920" (Ph. D. diss, University of Iowa, 2002), 302-310.

10. G. Kitson Clark, The Making of Victorian England (London: Methuen, 1962), 14, as quoted in Peter Novick, That Noble Dream: The "Objectivity Question" and the American Historical Profession (Cambridge: Cambridge University Press, 1988), 8, 384.

11. Receipts, 1877-1889, Box 1, Folder 3, Harry A. Joslyn Collection, NIU.

12. Post Publishing Co., Invoice for the Evening Post, 12 April 1905, pasted into Invoice Book, Box 11, Vol. 16, Falor, Crabb, and McGennis Families Collection, Western Historical Manuscript Collection-Kansas City, Missouri.

13. Isaac N. Carr, Front cover of diary, 15 January 1896-19 March 1898, Box 3, Isaac N. Carr Papers, SHSI-IC; Ayer 1895.

14. Dan Cummins, diary entries for 1 September 1904, 18 October 1910, 2 March 1912, 20 January 1913, 6 May 1914, 25 May 1915, 7 June 1919, 4 March 1920, 24 March 1920, Box 1, Folders 6-12, Cummins Family Papers, SHSI-IC.

15. John Campbell Bailey, 11 December 1896, 13 January 1898, 16 December 1898, 5 January 1899, 15 May 1899, 5 June 1899, 30 June 1899, 5 January 1900, 2 January 1901, 23 December 1901, 6 January 1902, 17 December 1902, 23 January 1903, 18 February 1903, 23 December 1903, 4 March 1904, 2 May 1905, 21 July 1905, 5 January 1906, 25 February 1907, 19 June 1907, 3 July 1908, 3 February 1909, 24 June 1909, 10 August 1909, 15 January 1910, 2 June 1910, 23 June 1910, 22 August 1911, 21 May 1913, 21 October 1913, 1 February 1914, 25 June 1915, 24 March 1916, 5 January 1917, 12 July 1917, 13 February 1918, 18 April 1919, Box 1, Folder 11 through Box 2, Folder 2, John Campbell Bailey Diaries, ISHL.

16. Ozias Ferree, Panora, Iowa, letters to Sue Leaman, Millersville, Pennsylvania, 22 December 1881, 12 September 1886, 9 October 1887, 1 November 1889, Folder 7, Ozias Ferree Papers, ISU.

17. Lizzie Shale Seipp, Hampton County, Iowa, letters to Christian and Margaret Shale, Ella Shale Stockman, [North Freedom, Wisconsin], 21 May 1880 and 1 August 1883, Shale and Wolf Families' Letters, IWA.

18. Milton W. Hamilton, The Country Printer: New York State, 1785-1830 (New York: Columbia University Press, 1936); Leonard, News For All, 1-32.

19. Gunther Barth, City People: The Rise of Modern City Culture in Nineteenth-Century America (New York: Oxford University Press, 1980), 58-109, Christine Pawley, Reading on the Middle Border: The Culture of 
Print in Late-Nineteenth-Century Osage, Iowa (Amherst: University of Massachusetts Press, 2001), 169-201.

20. This division is used in Van Derhoof, 15-17.

21. John Campbell Bailey, diary entries for 6 March 1885, 15 April 1885, 18 February 1996, 6 June 1887, 16 December 1887, 17 February 1888, 23 February 1891, 10 February 1892, 27 February 1893, 1 March 1895, 15 January 1896, 17 March 1897, 13 January 1898, 30 January 1899, 21 Fcbruary 1899, 11 January 1900, 7 February 1901, 21 January 1904, 10 November 1904, 8 January 1907, 2 March 1908, Box 1, Folders 7-15, John Campbell Bailey Diaries, ISHL.

22. Dan Cummins, diary entries for 18 October 1905, 7 January 1913, 4 October 1913, 26 April 1915, 6 October 1915, 20 September 1916, 1 October 1916, 28 November 1917, Box 1, Folders 6-11, Dan Cummins Diaries, SHSI-IC.

23. Ralph Otto Nafziger, "The History and Influence of the Farm Press in Wisconsin" (B. S. thesis, University of Wisconsin, 1920), 75. Nafziger later became a noted journalism researcher, professor, and head of the Department of Journalism at the University of Wisconsin-Madison. Steven H. Chaffee, "George Callup and Ralph Nafziger: Pioneers of Audience Research," Mass Communication and Society (3)(2/3)(Spring/Summer 2000): 317-327.

24. John Campbell Bailey, diary entries for 10 February 1892, 15 January 1896, 13 January 1898, 30 January 1899, Box 1, Folders 9-11, John Campbell Bailey Diaries, ISHL; Louis M. Monsees, clippings in folder 2, Louis M. Monsees Papers, Western Historical Manuscript Collection-Columbia, MO; John A. Sanborn, diary entries for 8 January 1906, 25 January 1907, vol. 8-9, John A. Sanborn, Diaries, 1899-1908, Western Historical Manuscript Collection-Columbia, Missouri.

25. Paul C. Gutjahr, An American Bible: A History of the Good Book in the United States, 1777-1880 (Stanford: Stanford University Press, 1999). Gilmore notes the central importance of the Bible as well, Reading Becomes a Necessity of Life, 254-263.

26. S. A. Paul, diary entries for 21 January 1914, 20 January 1917, folders 6-7, S. A. Paul Papers, SHSI-IC; George Marsden, Fundamentalism and American Culture: The Shaping of Twentieth Century Evangelicalism, 1870-1925 (Oxford: Oxford University Press, 1980), 118-123.

27. The popularity of Uncle Tom's Cabin among Iowa townspeople is noted by Christine Pawley, Reading on the Middle Border, 27. For anti-slavery sentiments in nineteenth century Iowa, see Robert Dykstra, Bright Radical Star: Black Freedom and White Supremacy on the Hawkeye Frontier (Cambridge: Harvard University Press, 1993), 195-272.

28. Sarah Jane Kimball, Diary entries for 26 February 1882, 9 February 1890, 20 February 1898, Box 1, folders 10-12, Sarah Jane Kimball Papers, SHSIIC.

29. Pawley, Reading on the Middle Border, 61-116; Denning, Mechanic Accents. 
30. USDA Publications List, Box 1, Folder 12, James H. Beed Papers, SHSI-IC; USDA Publications List, Box 6, Folder 11, Isaac N. Carr Papers, SHSI-IC.

31. John A. Sanborn, diary entries for 21 December 1899, 11 December 1903, vol. 1 and 5, John A. Sanborn, Diaries, 1899-1908, Western Historical Manuscript Collection-Columbia, Missouri.

32. Lucy Van Voorhis White, Dallas Center, Circular letter to family, 4 February 1910, Box 1, Lucy Van Voorhis White Papers, IWA.

33. Sce for example, Ladies' Home Journal, January 1910, 34.

34. Wilson, "The Rhetoric of Consumption."

35. Frank Luther Mott, A History of American Magazines, 1850-1865 (Cambridge: Harvard University Press, 1938), 262-274.

36. Receipt for the Chicago Journal, Box 1, Folder 3, Harry A. Joslyn Collection, NIU; Chicago Tribune, 7 July 1901, Clipping in Scrapbook, Box 3, Laura Cooper Collection, NIU; John A. Sanborn, diary entries for 14 January 1899, 17 September 1901, 20 September 1902, 8 January 1906, vol. 1, 3, 4, and 8, John A. Sanborn, Diaries, 1899-1908, Western Historical Manuscript Collection-Columbia, Missouri.

37. Isaac N. Carr, written on inside cover of diaries, 7 October 1883-24 September 1884, 16 July 1886-30 May 1890, 15 January 1896-19 March 1898, Boxes 2-3, Isaac N. Carr Papers, SHSI-IC; Delavan Times-Press, 8 July 1908; Ralph Allen, Delavan, IL, letter to the editor of the New York American, 30 June 1911, Boxes 4 \& 10, Allen Family Papers, UIUC; John M. Inman, diary entries for 2 January 1883, 7 January 1884, 10 January 1885 , Box 1, Folder 7, John M. Inman Diaries and Account Books, D 65, SHSI-IC.

38. John Campbell Bailey, diary entries for 13 December 1880, 2 November 1882, 12 February 1884, 15 December 1885, 14 December 1886, 4 December 1888, 7 December 1889, 2 October 1890, 28 December 1891, 28 December 1893, 8 December 1894, 27 February 1896, 27 November 1897, 17 December 1900, 2 December 1902, 16 November 1903, 14 November 1904, 15 November 1905, 19 November 1907, 2 November 1908, 2 July 1909, 10 June 1910, 28 October 1912, 12 October 1914, 19 October 1915, 12 December 1916, Box 1, Folders 5-16, Box 2, Folder 1, John Campbell Bailey Diaries, ISHL.

39. Lucy Van Voorhis White, Dallas Center, Iowa, Circular letter to family, 15 June 1910, 2 January 1916, Boxes 1 and 2, Lucy Van Voorhis White Papers, IWA.

40. Receipt for Weekly Mining Review, 1 March 1902, Box 11, vol. 16, Falor, Crabb, and McGennis Families Collection, Western Historical Manuscript Collection-Kansas City, MO; Winifred Davis Cornett, account book entry for 26 June 1908, Folder 59, Cornett Family Papers, Western Historical Manuscript Collection-Columbia, Missouri.

41. Skandinaven, Chicago, IL, 15 May 1915; Samband, Minneapolis, MN, April 1913; Sanger-Hilsen, Minneapolis, MN, 20 December 1913; Box 4, Folders 1, 2, Nehemias Tjernagel Papers, SHSI-IC. Tjernagel also subscribed to Wallaces' Farmer and the Youth's Companion.

42. Rachel Bohlmann, "Drunken Husbands, Drunken State: The Woman's Christian Temperance Union's Challenge to American Families and Public Communities in Chicago, 1874-1920" (Ph. D. diss, University of Iowa, 
2001); Carol Mattingly, Well-Tempered Women: Nineteenth-Century Temperance Rhetoric (Carbondale: Southern Illinois University Press, 1998); Eric Burns, The Spirits of America: A Social History of Alcobol (Philadelphia: Temple University Press, 2004), 97-146.

43. Cathy N. Davidson, Revolution and the Word: The Rise of the Novel in America (New York: Oxford University Press, 1986); Pawley, Reading on the Middle Border, 77-110.

44. Lucy Van Voorhis, Eldora, Iowa, letter to George Thomas White, Dallas Center, Iowa, 8 January 1896, Lucy Van Voorhis White Papers, IWA. Emphasis in original.

45. John A. Sanborn, diary entries for 21 December 1899, 11 December 1903, 8 January 1906, vol. 1, 5, and 8, John A. Sanborn, Diaries, 1899-1908, Western Historical Manuscript Collection-Columbia, Missouri.

46. Laura Smith, “Almost Pioneers," (unpublished manuscript, Ankeny: Life Story Enterprises, 1983), 58, Box 2, Laura Gibson Smith Papers, IWA.

47. Donald Sinnema, "Dutch American Newspapers and the Network of Early Dutch Immigrant Communities," in Dutch Enterprise: Alive and Well in North America, edited by Larry J. Wagenaar and Robert P. Swierenga (Pella, Iowa: Central College, 1999); Benedict Anderson, Imagined Communities: Reflections on the Origin and Spread of Nationalism, Rev. ed. (London: Verso, 1991); David Waldstreicher, In the Midst of Perpetual Fetes: The Making of American Nationalism, 1776-1820 (Chapel Hill: University of North Carolina, 1997); Pawley, Reading on the Middle Border.

48. Scrapbook, Box 3, Laura Cooper Collection, NIU; Jay Linn Torrey Scrapbook, Western Historical Manuscript Collection-Rolla, Missouri.

49. S. A. Paul, Diary entries for 12 January 1917,6 May 1917 , folder 7, S. A. Paul Diaries, SHSI-IC.

50. Lucy Van Voorhis White, Dallas Center, Iowa, Circular letter to family, 28 December 1908, Box 1, Lucy Van Voorhis White Papers, IWA. The clipping is gone.

51. Ozias Ferree, Panora, Iowa, letter to Sue Leaman, Millersville, Pennsylvania, 9 October 1887, folder 7, Ozias Ferree Papers, ISU. Emphasis in original.

52. Ozias Ferree, Panora, Iowa, letter to Sue Leaman, Millersville, Pennsylvania, 1 November 1889, folder 7, Ozias Ferree Papers, ISU.

53. James R. Howard, "Making an Iowa Farmer," (unpublished memoir: n.d.), 31, SHSI-IC.

54. Pawley, Reading on the Middle Border, 145-153; Anne Firor Scott, Natural Allies: Women's Associations in American History (Urbana: University of Illinois Press, 1991).

55. Robert P. Howard, James R. Howard and the Farm Bureau (Ames: Iowa State University Press, 1983).

56. “August 5th Subscribed for the Wallace [sic] Farmer \$1.00." Walnut Chapter Secretary's [Treasurer's?] Book, entry for 5 August 1902, Daughters of Ceres Records, IWA.

57. Emma Terhune, Secretary, Walnut Chapter, Daughters of Ceres, Minutes of Meetings, 3 November 1898, 12 October 1899, Daughters of Ceres Records, 
IWA; “Meeting of State Organization of Daughters of Ceres," WF, 3 June 1898; “A New Chapter,” WF, 2 September 1898.

58. Barth, City People, 58-109; Leonard, News for All; Christine Pawley, Reading on the Middle Border, 137-168, see also Christine Pawley, "Not Wholly Self Culture': The Shakespearean Women's Club, Osage, Iowa, 1892-1920," Annals of Iowa 56(1/2)(Winter/Spring 1997): 12-45.

59. Sarah Jane Kimball, diary Entry for 28 January 1900, Diary, 17 June 1900-29 December 1901, Box 2, Folder 2, Sarah Jane Kimball Papers, SHSI-IC.

60. Sarah Jane Kimball, diary entries for 3 February 1875, 20 February 1875, 27 March 1875, 1 January 1876, 26 February 1882, 10 September 1882, 18 February 1883, 14 October 1888, 3 February 1889, 24 February 1889, 9 February 1890, 2 January 1898, 23 January 1898, 20 February 1898, 27 March 1898, Box 1, folders 7, 8, 10, 11, 12, Sarah Jane Kimball Papers, SHSI-IC.

61. Mary H. O'Neill, diary entries for 1 January, 5 January, 12 February, 26 February, 28 March, 5 April, 20 November 1899, Mary H. O’Neill Diary, 1899, Western Historical Manuscript Collection-Columbia, Missouri. Italics added.

62. Mary H. O'Neill, diary entry for 10 December 1899, Mary H. O'Neill Diary, 1899, Western Historical Manuscript Collection-Columbia, Missouri.

63. Pawley, Reading on the Middle Border, 69-116.

64. Isaac N. Carr, Front cover of diary, 15 January 1896-19 March 1898, Box 3, Isaac N. Carr Papers, SHSI-IC.

65. Isaac N. Carr, front cover of diaries for 7 October 1883-24 September 1884, 25 September 1884-12 July 1886, 16 July 1886-30 May 1890, and 16 August 1892-14 January 1896, Boxes 2-3, Isaac N. Carr Papers, SHSIIC. The Iowa Homestead article was "Potato Scab," IH 22 November 1895, 1108.

66. Lucy Van Voorhis White, letter to family, 30 April 1908, 5 March 1912, Box 1 and Box 2, Lucy Van Voorhis White Papers, IWA.

67. "S. H.," "An Occupation for Women," WF 9 September 1898, 10.

68. Iowa Manuscript Census; Atlas of Dallas County Iowa (Mason City: Anderson Publishing Company, 1916), 16-17. S. Morgan Friedman, "The Inflation Calculator," http://www.westegg.com/inflation/; internet; accessed 4 November 2004.

69. Deborah Fink, Open Country, Iowa: Rural Women, Tradition and Change (Albany: State University of New York Press, 1986).

70. Lucy Van Voorhis White, Dallas Center, Iowa, Circular letter to family, 11 March 1908, 30 April 1908, 22 May 1908, 27 November 1908, 8 April 1909, 4 February 1910, 5 March 1912, Boxes 1-2, Lucy Van Voorhis White Papers, IWA.

71. Charles Major, Yolanda, Maid of Burgundy (New York: MacMillan, 1905); Harold Bell Wright, When a Man's a Man (New York: A. L. Burt, 1916); Lucy Van Voorhis White, Circular letter to family, 15 May 1907, Box 1; 23 February 1914, 16 March 1917, Box 2, Lucy Van Voorhis White Papers, IWA. 
72. It appears that this may be Jerry McAuley, Jerry McAuley: His Life and Work, 2nd ed. (New York: New York Observer, 1885) or another edition.

73. Lucy Van Voorhis White, Circular letter to family, 26 February 1910, Box 1; 23 February 1915, 24 January 1916, 27 January 1920, Box 2, Lucy Van Voorhis White Papers, IWA; Henry Ormal Severance, A Guide to the Current Periodicals and Serials of the United States and Canada 1907 (Ann Arbor: George Wahr, 1907), 62-63, 246.

74. Federal Manuscript Census; John A. Sanborn, diary entries for 2 January 1899, 23 March 1899, 6 May 1899, 7 June 1899, 28 July 1899, 6 September 1899, 25 September 1899, 26 September 1899, vol. 1, John A. Sanborn Diaries, 1899-1908, Western Historical Manuscript CollectionColumbia, Missouri.

75. John A. Sanborn, diary entry for 31 December 1899, vol. 1, John A. Sanborn Diaries, 1899-1908, Western Historical Manuscript CollectionColumbia, Missouri. . \$1,500 in 1899 was worth about \$32,000 in 2003. S. Morgan Friedman, “The Inflation Calculator," http://www.westegg.com/ inflation/; internet; accessed 4 November 2004.

76. John A. Sanborn, diary entries for 14 January 1899, 21 December 1899, vol. 1; 27 January 1900, 24 March 1900, vol. 2, John A. Sanborn Diaries, 1899-1908, Western Historical Manuscript Collection-Columbia, Missouri.

77. John A. Sanborn, diary entries for 30 June 1900,8 July 1900,14 July 1900 , 13 September 1900, 17 September 1900, 18 September 1900, 19 September 1900, 22 December 1900, vol. 2, John A. Sanborn Diaries, 1899-1908, Western Historical Manuscript Collection-Columbia, Missouri.

78. John A. Sanborn, diary entries for 14 July 1900, 23 September 1900, 24 September 1900, vol. 2, John A. Sanborn Diaries, 1899-1908, Western Historical Manuscript Collection-Columbia, Missouri.

79. Paul Leicester Ford, Janice Meredith: A Story of the American Revolution (New York: Grosset and Dunlap, 1899); Thomas Nelson Page, Red Rock: A Chronicle of Reconstruction (New York: Charles Scribner's Sons, 1899); Winston Churchill, Richard Carvel (New York: Macmillan, 1899); Lew Wallace, The Prince of India: Or, Why Constantinople Fell (New York: Harper, 1893); Charles Major, When Knighthood Was in Flower (Indianapolis: Bobbs Merrill, 1900); Mary Johnston, To Have and To Hold (Boston: Houghton Mifflin, 1900); Jessie Fothergill, First Violin (New York: Lupton, 189?, first published 1878); Paul Leicester Ford, The Honorable Peter Stirling and What People Thought of Him (New York: Holt, 1897); William C. Gannett, The House Beautiful (River Forest, Ill: Auvergne Press, 1897).

80. Last page of vol. 2, John A. Sanborn Diaries, 1899-1908, Western Historical Manuscript Collection-Columbia, Missouri. Wordsworth's brief poem (3 stanzas) concludes "She lived unknown, and few could know I When Lucy ceased to be; / But she is in her grave, and, oh, / The difference to me!" The poem was composed in 1799 and published in 1800 . William Wordsworth, The Poetical Works of William Wordsworth, ed. E. De Selincourt (Oxford: Clarendon Press, 1952), vol. 2, p. 30. 
81. Margaret L. Knapp, "Mother," The Atlantic Monthly 85(507)(January 1900): $110-119$.

82. John A. Sanborn, diary entry for 17 September 1901, 23 December 1901, vol. 3; 21 April 1902, 26 April 1902, vol. 4; 11 December 1903, vol. 5; 8 January 1906, 28 January 1906, vol. 8; 25 January 1907, 30 March 1907, vol. 9; 5 March 1908, 3 April 1908, vol. 10, John A. Sanborn Diaries, 1899-1908, Western Historical MaWnuscript Collection-Columbia, Missouri.

\section{NOTES TO CHAPTER FOUR}

1. This title is taken from Sally McMurry, "Who Read the Agricultural Journals? Evidence from Chenango Co., NY, 1839-1865," Agricultural History 63(4)(Fall 1989): 1-18.

2. Twain, "Memoranda," 135. Emphasis in original.

3. For the nineteenth century, see Demaree, The American Agricultural Press, 122-123; Bardolph, Agricultural Literature and the Early Illinois Farmer, 93; Paul Wallace Gates, The Farmer's Age: Agriculture, 1815-1860 (New York: Holt, Rinehart, and Winston, 1960); 344-346; Donald B. Marti "Agricultural Journalism and the Diffusion of Knowledge: The First HalfCentury in America," Agricultural History 54(1)(January 1980): 37.

4. Nafziger, "The History and Influence of the Farm Press in Wisconsin," 73-84.

5. McMurry, "Who Read the Agricultural Journals?" This article parallels David Paul Nord's examination of the subscription list of a New York newspaper in "A Republican Literature: Magazine Reading and Readers in Late-Eighteenth Century New York," in Reading in America: Literature and Social History, ed. Cathy N. Davidson (Baltimore: Johns Hopkins University Press, 1989), 114-139. For social science surveys of later periods, see Russell G. Mawby and Cecil B. Haver, "Types and Sources of Information Used by Farmers," in A Study of Managerial Processes of Midwestern Farmers, ed. Glenn L. Johnson et al. (Ames: Iowa State University Press, 1961), 24-40 and Stephen A. Ford and Emerson M. Babb, "Farmer Sources and Uses of Information," Agribusiness 5(5)(September 1989): 465-476.

6. I was pointed towards these sources by Helen Damon-Moore and Carl F. Kaestle, "Surveying American Readers," in Carl F. Kaestle et al., Literacy in the United States: Readers and Reading Since 1880 (New Haven: Yale University Press, 1991): 180-181 and William S. Gray and Ruth Monroe, The Reading Interests and Habits of Adults: A Preliminary Report (New York: MacMillan, 1930): 93-103.

7. William H. Mills Papers, ISU. When I looked through these papers, they were unprocessed.

8. McMurry makes the same disclaimer in "Who Read the Agricultural Journals?" On county histories, see James Malin, "The Vanity Histories," Kansas Historical Quarterly 21(Winter 1955): 498-643.

9. The North Atlantic route went South through eastern New York, eastern Pennsylvania, and Eastern Maryland; the Southern route went through 
central Georgia, Alabama, and east central Mississippi. Smith and Atwood, "The Relation of Agricultural Extension Agencies to Farm Practices," 14.

10. Demonstration agents had only just begun to work and were concentrated in the South; Smith and Atwood, 15-21.

11. Paul S. Peirce, "Social Surveys of Three Rural Townships in Iowa," University of Iowa Monographs-Studies in the Social Sciences 5(2)(1917): 13.

12. Mary Neth provides a good introduction to rural sociology in Preserving the Family Farm, 97-121.

13. George H. Von Tungeln and W. A. Brindley, "A Rural Social Survey of Lone Tree Township, Clay County, Iowa," Iowa State College Agricultural Experiment Station Bulletin 193(March 1920), 235. George H. Von Tungeln et al., "The Social Aspects of Rural Life and Farm Tenantry, Cedar County, Iowa, Iowa State College Agricultural Experiment Station Bulletin 217(August 1923), 467; George H. Von Tungeln and Harry L. Eells, "Rural Social Survey of Hudson, Orange, and Jesup Consolidated School Districts, Blackhawk and Buchanan Counties, Iowa," Iowa State College Agricultural Experiment Station Bulletin 224(November 1924); the surveys for these two reports were done during the summer of 1920; George H. Von Tungeln, J. E. Thaden, and E. L. Kirkpatrick, "Cost of Living on Iowa Farms," Iowa State College Agricultural Experiment Station Bulletin 237(June 1926), 37; J. F. Thaden, "Cost of Living on Iowa Farms," Iowa State College Agricultural Experiment Station Bulletin 238(August 1926), 119-120.

14. Carl C. Taylor, Rural Sociology: A Study of Rural Problems (New York: Harper and Brothers, 1926), 268-271.

15. Gray and Munroe, 99.

16. "If any of you are solicited to subscribe for the Mother's Magazine (Elgin, Ill.) save it for Louise. She has undertaken to get a few subscriptions and I think will have six to send in soon. It is well worth working for and is highclass so I feel gratified whenever we can get any of our neighbors to take it. I sold two subscriptions today to Arthur to send to his two sisters. Two beautiful pictures go with a 50 cent subscription." Lucy Van Voorhis White, Dallas Center, Iowa, Circular letter to family, 22 May 1908, Box 1, Lucy Van Voorhis White Papers, IWA.

17. Federal Manuscript Census; Atlas and Plat Book of Story County Iowa (Des Moines: Kenyon Co., 1926), 23; 1915 Iowa Manuscript Census; 1917 Iowa Income Tax Return, William H. Mills Papers, ISU.

18. H. H. Johnston, Circulation Manager, Wallaces' Farmer, Des Moines, Iowa, letter to William H. Mills, Ames, Iowa, 6 January 1928, William H. Mills Papers, ISU.

19. Atlas of Story County Iowa; Directory of Story County Iowa Cities, Towns, and Rural Routes (Ames: Ames Evening Times, 1914); Iowa State College of Agriculture and Mechanic Arts General Directory, 1926-1931 (Ames: Iowa State College, 1926); The Bomb (Ames: Published by the Students of Iowa State College, 1926, 1928, 1931).

20. McMurry, "Who Read the Agricultural Journals?": 5.

21. McMurry, "Who Read the Agricultural Journals?": 3. 
22. United States Historical Census Data Browser, available from http://fisher.lib.virginia.edu/ census/; Internet; accessed 22 September 2004.

23. S. Morgan Friedman, "The Inflation Calculator," http://www.westegg.com/ inflation/; internet; accessed 4 November 2004.

24. McMurry, "Who Read the Agricultural Journals?," 3, 9.

25. Jon Gjerde, The Minds of the West: Ethnocultural Evolution in the Rural Middle West, 1830-1917 (Chapel Hill: University of North Carolina Press, 1997); Franklin Lee Yoder, “A Rural Kaleidoscope: Property, Mobility, and Ethnic Diversity in the Middle West," (Ph. D. diss., University of Chicago, 1999).

26. The journey or tour as a way of organizing and presenting information is used to good effect in William Cronon's Nature's Metropolis: Chicago and the Great West (New York: Norton, 1991), 104-108.

27. The Past and Present of Rock Island County (Chicago: H. F. Kett and Company, 1877); Historical Encyclopedia of Illinois and History of Rock Island County (Chicago: Munsell Publishing Company, 1914), volume 2, 1009.

28. Federal Manuscript Census; 1880 Federal Manuscript Census of Agriculture. S. Morgan Friedman, "The Inflation Calculator," http://www.westegg.com/inflation/; internet; accessed 4 November 2004.

29. John Campbell Bailey, diary entry for 11 January 1900, John Campbell Bailey Diaries, ISHL.

30. John Campbell Bailey, diary entries for 18 February 1886, 17 February 1888, 23 February 1891, 27 February 1893, 1 March 1895, 17 March 1897, 21 February 1899, 7 February 1901, 21 January 1904, 15 April 1885, 6 June 1887, 16 December 1887, 10 November 1904, 2 March 1908, 8 January 1907, John Campbell Bailey Diaries, ISHL.

31. John Campbell Bailey, 11 December 1896, 13 January 1898, 16 December 1898,5 January 1899,15 May 1899,5 June 1899,30 June 1899,5 January 1900, 2 January 1901, 23 December 1901, 6 January 1902, 17 December 1902, 23 January 1903, 18 February 1903, 23 December 1903, 4 March 1904, 2 May 1905, 21 July 1905, 5 January 1906, 25 February 1907, 19 June 1907, 3 July 1908, 3 February 1909, 24 June 1909, 10 August 1909, 15 January 1910, 2 June 1910, 23 June 1910, 22 August 1911, 21 May 1913, 21 October 1913, 1 February 1914, 25 June 1915, 24 March 1916, 5 January 1917, 12 July 1917, 13 February 1918, 18 April 1919, Box 1, Folder 11 through Box 2, Folder 2, John Campbell Bailey Diaries, ISHL.

32. The information on turn of the century railroads is from: Commissioners Official Railway Map of Missouri (St. Louis: Higgins, 1898); Map of Iowa Prepared and Printed for the Rail Road Commissioners to Accompany their Report (Chicago: Rand McNally, 1902); Rand McNally \& Company's Indexed Atlas of the World (Chicago: Rand McNally, 1902), 154-155.

33. Portrait and Biographical Album of Washington County, Iowa (Chicago: Acme Publishing Company, 1887), 363-364; Howard A. Burrell, History of Washington County, Iowa from the First White Settlements to 1908 (Chicago: S. J. Clarke, 1909), vol. II, 92-93. 
34. Federal Manuscript Census of Agriculture; Plat Book of Washington County Iowa (Philadelphia: North West Publishing Company, 1894), 20-21; Property Tax Assessment Receipt, folder 9, box 6, Isaac N. Carr Papers, SHSI-IC.

35. Iowa Homestead Subscription Notice, Box 6, Folder 12, Isaac N. Carr Papers, SHSI-IC.

36. Isaac N. Carr, Written inside of front cover of Diary, 16 August 1892-14 Jan 1896, Box 3, Isaac N. Carr Papers, SHSI-IC.

37. "Membership Certificate-This is to certify that $I$. N. Carr has paid a membership of $\$ 1.00$ and is entitled to all the rights and privileges of the Local Library for a term of two years from date, said library to be located with $E$. H. Hookey of Wellman Ia who agrees to act as librarian during the term. It is understood and agreed that there thall [sic] be no other dues whatever during the life of this certificate; that the library shall be exchanged two times during the two years mentioned, that the last set of books completing this contract shall become the property of the members to be disposed of as directed by a majority of the membership. Dated this 18 th day of July 1906" Italics signify where portions of the preprinted form were filled in in longhand. Box 6, Folder 8, Isaac N. Carr Papers, SHSI-IC.

38. Isaac N. Carr, diary entry for 1 January 1923, Box 5, Isaac N. Carr Papers, SHSI-IC. The article was "Potato Scab," IH 22 November 1895, 1108.

39. Finding Aid, May Bennett Harshbarger Papers, IWA.

40. Iowa Manuscript Census; 1920 Federal Manuscript Census; Atlas of Carroll County Iowa (Des Moines: Anderson Publishing Company, 1923), XVIIIXIX. S. Morgan Friedman, "The Inflation Calculator," http://www.westegg.com/inflation/; internet; accessed 4 November 2004.

41. May Bennett Harshbarger, account book entries, 15 December 1911, 28 February 1912, 31 December 1912, 8 Mar 1913, 20 December 1913, 29 January 1914, May Bennett Harshbarger Papers, IWA.

42. "History of the Goldenrod Club," title of newspaper not given, 1 September 1949, May Bennett Harshbarger Papers, IWA.

43. History of Monona County, Iowa (Chicago: National Publishing Company, 1890), 264.

44. Dan Cummins, diary entry for 29 June 1904, Box 1, Folder 6, Cummins Family Papers, SHSI-IC.

45. Property Tax Receipts, 1905-1921, Box 3, Folder 8, Cummins Family Papers, SHSI-IC; 1915 Iowa Manuscript Census; Atlas of Monona County Iowa (Mason City: Anderson Publishing Company, 1919), 19. S. Morgan Friedman, "The Inflation Calculator," http://www.westegg.com/inflation/; internet; accessed 4 November 2004.

46. John Mack Faragher comments on a similar pattern in his comparisons of the diaries of women and men overland migrants, Women and Men on the Overland Trail (New Haven: Yale University Press, 1979), 129-133.

47. Dan Cummins, Account entries in back of diary for 11 October 1911, 7 January 1913, 4 October 1913, 4 October 1914, 26 April 1915, 6 October 1915, 1 October 1916, 3 January 1919, 7 January 1919, 25 September 
1919, 3 October 1919, 9 October 1919, Box 1, Folders 9-11, Cummins Family Papers, SHSI-IC.

48. Federal Manuscript Census; 1920 Federal Manuscript Census; "Evolution of Monsees," MR 12 October 1905, 5.

49. John Francis Case, "Jacks-and a Million Dollars," MR 20 March 1918, 3, 7; Breeder's Gazette, 7 February 1912, MR, 10 February 1912, IH, 15 February 1912, WF, 16 February 1912, Folder 2; Correspondence 1903-1928, Folder 4, Louis M. Monsees Papers, Western Historical Manuscript Collection-Columbia, Missouri.

50. “Monsees Breaks Record," MR 8 March 1906, 7; “L. M. Monsees \& Sons' Sale," MR 15 March 1906, 8; Plat Book of Pettis County, Missouri (Philadelphia: North West Publishing Company, 1896), 6, 39; Plat Book of Pettis County, Missouri (Philadelphia: A. R. Stinson, 1916), 8, 28.

51. Federal Manuscript Census of Agriculture. S. Morgan Friedman, "The Inflation Calculator," http://www.westegg.com/inflation/; internet; accessed 4 November 2004.

52. Ralph Allen, Champaign, Illinois, letter to Ada Eaton, Delavan, Illinois, 3 August 1877, Box 2, Allen Family Papers, UIUC; 1900 Federal Manuscript Census, 1920 Federal Manuscript Census.

53. J. H. Sanders Company, Chicago, Ill., letter to J. B. Allen \& Son Breeders, 8 October 1883, Box 2 Allen Family Papers, UIUC. S. Morgan Friedman, “The Inflation Calculator," http://www.westegg.com/inflation/; internet; accessed 4 November 2004.

54. “Seed Corn Selection," PF, 18 December 1902; "Saving our Best Lands," PF, 19 February 1903; “Testing Soil at Home,” PF, 26 February 1903, Box 3, Allen Family Papers, UIUC.

55. J. H. Sanders Company, Chicago, Ill., letter to J. B. Allen \& Son Breeders, 13 October 1884, Box 2, Allen Family Papers, UIUC.

56. Box 3, Allen Family Papers, UIUC.

57. Anonymous renter of Settle farm, diary entries for 23 March 1910, 4 April 1910, Settle Farm Day Book, NIU.

\section{NOTES TO CHAPTER FIVE}

1. "Boys and Girls on the Farm," MR 3 February 1912, 4.

2. Swierenga, "The Little White Church," 417.

3. Report of the Country Life Commission, 60.

4. Malcolm J. Rohrbough, The Trans-Appalachian Frontier: People, Societies, and Institutions, 1775-1850 (New York: Oxford University Press, 1978), 60-62, 145-151; Neth, Preserving the Family Farm, 53-54, 68-69; Swierenga, "The Little White Church," 415-441; Jane Marie Pederson, Between Memory and Reality: Family and Community in Rural Wisconsin, 1870-1970 (Madison: University of Wisconsin Press, 1992); U. S. Bureau of the Census, Religious Bodies: 1926 (Washington: GPO, 1930), v. 1, 136-141.

5. David R. Reynolds, “The Making of Buck Creek: Country Life Reform, Religion, and Rural School Consolidation," Annals of Iowa 58(4)(Fall 1999): 351-387. 
6. Mark A. Noll, "Linking Billy Sunday and the Mystique of the Middle West to the Religious History of Iowa," The Annals of Iowa 55(4)(Fall 1996): 362-368; U. S. Bureau of the Census, Religious Bodies: 1906 (Washington: GPO, 1910), v. 1, 45-53; Edwin Scott Gaustad, Historical Atlas of Religion in America, Rev. ed. (New York: Harper and Row, 1972).

7. Sydney Ahlstrom, A Religious History of the American People (New Haven: Yale University Press, 1972), 733-819; Mark A. Noll, A History of Christianity in the United States and Canada (Grand Rapids: Eerdmans, 1992), 363-386; Marsden, Fundamentalism and American Culture.

8. Roger Finke and Rodney Stark, The Churching of America, 1776-1990: Winners and Losers in Our Religious Economy (New Brunswick: Rutgers University Press, 1992), 202-216; Robert C. McMath, “Comment," Paper presented at Organization of American Historians Midwestern Regional Conference, Ames, Iowa, 5 August 2000.

9. Religious Bodies: 1906, vol. 1, 305-308, 311-314, 331-334; United States Bureau of the Census, Religious Bodies: 1926, 167-171, 176-181, 206-209; Census of Iowa for the Year 1915 (Des Moines: Robert Henderson, 1915): cxii-cxiii.

10. Another way of saying this is that the rural church was "contested terrain," and that the Midwestern farm newspaper became a "site of contestation," giving conflicting descriptions of the state of the rural church.

11. "Elijah, the Reformer," WF 15 July 1898, 7; "An Ancient Land Transaction," WF 29 July 1898, 4; “The Sabbath School Lesson," WF 21 October 1898, 782; “Our Weekly Sabbath School Lesson. By The Editor. The Coming of the King," WF 4 January 1901, 3; Kirkendall, Uncle Henry, 137-139; Henry Wallace, Uncle Henry's Own Story of His Life, vol. 3, 89-93.

12. “Our New Department," IH 31 December 1903, 6; "Preaching of John Baptist [sic]" in "Pleasant Fields of Holy Writ," IH 7 January 1904, 3.

13. Letters to "Our Home Department:" E. G. Willson, “A Book Talk," IH 19 April 1895, 10; “June," “A Book Talk" IH 31 May 1895, 11; M. V. Halsted, "The Sabbath School," IH 5 July 1895, 11; E. G. Willson, "Prove All Things," IH 9 August 1895, 10; Jasper Blines, "Human Character as Modified by Literature," IH 9 August 1895, 11; Ellen J. Cannady, "Dangers to Our Young People," IH 24 January 1896, 10; Ruben E. Sanders, "How Can the [Sunday School] Teacher Secure Home Study on the Part of the Scholars," IH 21 November 1901, 17.

14. "Millions for Humanity," IH 29 January 1903, 4; "Sunday on the Farm," IH 29 June 1905, 1006.

15. "Making Money for the Church," $M R 12$ October 1905, 7; "Free Gift for Ruralist Readers," MR 10 November 1904, 5; "Sunday," PF 2 January 1897, 11; Florence Holmes, "Old-Fashioned Sunday School," PF 12 February 1898, 11.

16. “Social Side of the Farmer's Life," WF 11 October 1895, 1.

17. Robert C. McMath, Jr., American Populism: A Social History, 1877-1898 (New York: Hill and Wang, 1993), 180-211.

18. "Social Life in the Country," WF 17 April 1903, 587. 
19. “Why Not Stay on the Farm?” WF 23 November 1906, 1393.

20. “A Revived Farmer's Church," WF 6 January 1911, 29.

21. "A Revived Farmer's Church," WF 6 January 1911, 29; "Federation of Churches," WF 14 January 1916, 44.

22. "A Wider Use for Churches," WF 16 February 1912, 310; "The Use of the Country Church," WF 7 June 1912, 949.

23. “A Revived Farmers' Church," WF 14 January 1911, 29; Matthew B. McNutt, "Ten Years in a Country Church," The World's Work, Deccmbcr 1910, 13761-13766; Matthew B. McNutt, “Reviving a Country Church," WF 8 September 1911, 1233. None of these articles gives the denominational affiliation of the McNutt's church, but an article in the Iowa Homestead reveals that it was Presbyterian: "Vitalizing the Country Church," IH, 4 July 1912, 3, 9.

24. Christian Haupt, “A Live Country Church," WF 27 February 1914, 352.

25. Letters to WF: C. R. Green, 16 June 1911, 947; A. G. Stewart, 16 June 1911, 956; J. F. Hinkhouse, 10 April 1914, 619; Bert McDonald, 10 April $1914,629$.

26. James M. Pierce, "Cleanliness Akin to Godliness," IH 29 January 1914.

27. H. M. Harwood, "The Country Minister and the Rural Church Problem," IH 11 January 1912, 36; "The Country Church and its Pastor," IH 11 April 1912, 5-6; "Vitalizing the Country Church," IH 4 July 1912, 3, 9; "Rules for the Rural Pastor," IH 23 January 1913, 4.

28. C. V. Gregory, “The Mission of the Country Church," Successful Farming, January 1910, 70.

29. Rex Beresford, “New Light on Country Life Problems," PF 15 July 1911, 3; Rex Beresford, "A Plea for New Leadership in the Country Church," PF 15 December 1911, 3, 20-21.

30. "Boys and Girls on the Farm," MR 3 February 1912, 3, 20-21.

31. Rohrbough, 60-62, 145-151, 187-191, 342-344; John Mack Faragher, Sugar Creek: Life on the Illinois Prairie (New Haven: Yale University Press, 1986), 156-170; Pederson, 116-138.

32. "The Relation of the Country Pastor to Scientific Agriculture," WF 25 March 1910, 537-538.

33. "Easter in the Country Church," WF 15 March 1912, 506; "Prosperous Country Churches,"WF 18 September 1914, 1251.

34. "Possibilities of the Country Church," WF 5 June 1914, 877.

35. "Federation of Churches," WF 14 January 1916, 44; "Sick Country Churches," WF 14 January 1916, 45.

36. “The Rural Church," IH 10 November 1910, 1939. For school consolidation, see chapter six.

37. "Vitalizing the Country Church," IH 4 July 1912, 3, 9.

38. Rex Beresford, "A Plea for New Leadership in the Country Church," PF 15 December 1911, 3.

39. John F. Case, "When Churches Get Together," MR 20 April 1915, 4; John F. Case, "In Defense of the Pastor," MR 5 July 1915, 4. 
40. "The Revival of the Country Church," WF 7 July 1911, 1007; "An Up-ToDate Church," WF 3 May 1912, 805; "Possibilities of the Country Church," WF 5 June 1914, 877.

41. "Boys and Girls on the Farm," MR 3 February 1912, 4; "Promotion of Bigotry," MR 23 July 1910, 4.

42. Rex Beresford, "A Plea for New Leadership in the Country Church," PF 15 December 1911, 21.

43. This was especially the case at the University of Chicago. See George Marsden, The Soul of the American University: From Protestant Establishment to Established Nonbelief (New York: Oxford University Press, 1994), 236-256.

44. Stow Persons, American Minds: A History of Ideas (New York: Holt, Rinehart \& Winston, 1958), 163-172.

45. "The Country Preacher," IH 22 June 1911, 1272.

46. "Defending the Country Preacher," IH 27 April 1911, 996; "The Country Preacher Needed," IH 11 May 1911, 1077; "The Country Preacher," IH 22 June 1911, 1272; “The Rural Pastor's Opportunity,” IH 6 July 1911, 1321; "The Country Minister and the Rural Church Problem," IH 11 January 1912, 36; "Exit the Rural Pastor," IH 23 January 1913, 176.

47. "The Relation of the Country Pastor to Scientific Agriculture," WF 25 March 1910, 537.

48. "The Relation of the Country Pastor to Scientific Agriculture," WF 25 March 1910, 537-538; "The Rural Church," WF 16 September 1910, 1230; "The Rural Church Problem," WF 9 December 1910, 1648.

49. "The Relation of the Country Pastor to Scientific Agriculture," WF 25 March 1910, 537-538; "The Country Church and Farm Prosperity," WF 12 May 1911, 803; “A Typical Country Church," WF 13 August 1915, 1077.

50. "The Relation of the Country Pastor to Scientific Agriculture," WF 25 March 1910, 537-538; "Summer School for Country Preachers," WF 8 July 1910, 962; "The Country Church and Farm Prosperity," WF 12 May 1911, 803. Amherst's president was Kenyon Butterfield, a member of the Country Life Commission.

51. "Training Country Pastors," PF 1 July 1911, 21; "Are Farmers Atheists," PF 1 November 1911, 14; "The Country Preacher," PF 1 February 1912; "Agriculture for Preachers," PF 15 November 1913, 10; "How About Your Preacher?" PF 29 January 1916, 90; Rex Beresford, "New Light on Country Life Problems," PF 15 July 1911, 3; Rex Beresford, "A Plea for New Leadership in the Country Church," PF 15 December 1911, 3, 20-21.

52. Quote from John F. Case, "Pastors That Do More Than Preach," $M R 5$ March 1915, 4; John F. Case, "Resident Pastors are Needed," MR 20 October 1914, 3; N. M. Tatum, "This Pastor Has 'Pep," MR 20 October 1915, 19; John F. Case, “A Community Evangelist," $M R 20$ November $1915,4$.

53. "Rules for the Rural Pastor," IH 23 January 1913, 156. 
54. "The Trouble with the Rural Church," WF 1 November 1918, 1597; "Preaching and Farming," WF 24 September 1920, 2239; "Locating the Parsonage," WF 5 January 1917, 5.

55. Three churches were the subjects of pieces in more than one of the farm newspapers studied between 1908 and 1916: M. B. McNutt's Presbyterian church near Plainsfield, Illinois; Rev. W. W. Diehl's Methodist church in Hinckley, Illinois; and C. R. Green's Methodist church in Harmony, Missouri.

For McNutt: “A Revived Farmers' Church,” WF 6 January 1911, 29; “Country Life Conference," IH 6 July 1911, 1320; Rex Beresford, "New Light on Country Life Problems," PF 15 July 1911, 3; “A Live Country Church," IH 27 July 1911, 1395, 1406; M. B. McNutt, "Reviving a Country Church," WF 8 September 1911, 1233; "Vitalizing the Country Church," IH 4 July 1912, 3, 9; "Rules for the Rural Pastor," IH 23 January 1913, 156; Ray L. Carr, "The Inside Story of A Modern Country Church," PF 1 February 1913, 11, 24, 36.

For Diehl: W. W. Diehl, “What One Church is Doing for Its Community," PF 31 July 1915, 527, 545; W. W. Diehl, "Helping the Country Church," IH 12 August 1915, 1410-1411.

For Green: C. R. Green, letter to WF 16 June 1911, 947; John F. Case, "Harmony-A Church Living Up to Its Name," MR 5 June 1914, 3, 10; "Building Up the Country Church," IH 31 December 1914, 2163-2164; George S. Banta, letter to IH 28 January 1915, 190; Frank D. Tomson, "Church Breeds Shorthorns," PF 6 May 1916, 442; A. A. Jeffrey, "Harmony-They Still do Things," MR 5 July 1919, 1, 7; A. A. Jeffrey, “A Farmers' Chautauqua," MR 5 January 1920, 10.

56. "Increasing Church Attendance," WF 25 August 1916, 1114; Mary Clelland, “A Model Rural Church," WF 24 November 1916, 1532; "The Work of Harmony Church," WF 29 March 1918, 567; "A Country Church Chautauqua," WF 4 October 1918, 1410; “A Church at Work," WF 28 February 1919, 542; "A Live Country Church," WF 7 March 1919, 592; Rev. Henry L. Rust, “A Live Community Church,” WF 7 March 1919, 592; "The Church of the Fat Land," WF 25 July 1919, 1429; "Community Church at Leroy, Iowa," WF 8 August 1919, 1527; “A Country Community Center," WF 14 November 1919, 2273; A. A. Jeffrey, "There's a Chance for the Country Church," WF 19 December 1919, 2513, 2532-2533; Cyrus E. Albertson, "When a Community Wakes Up," WF 13 February 1920, 546; "A Church of the Open Country," WF 20 February 1920, 617, 629; H. E. Trimble, "Point Pleasant Community Church," WF 14 June 1920, 1577.

57. James M. Pierce, "Country Church Problem in Grain Belt," IH 8 March 1917, 483.

58. James M. Pierce, "Use of the Farm Auto for Churchgoing," IH 26 September 1918, 1742; James M. Pierce, "The Hope of the Little White Church," IH 22 May 1919, 1390; James M. Pierce, “The Religion of the Soldier," IH 26 June 1919, 1632; William A. Atwell, “The Interchurch Movement," IH 25 March 1920, 1190-1191; James M. Pierce, "Iowa State College Considers the Country Church," IH 17 June 1920, 1955. On the Interchurch World 
Movement, see Eldon G. Ernst, Moment of Truth for Protestant America: Interchurch Campaigns Following World War One (Missoula, Montana: The American Academy of Religion and Scholars' Press, 1974).

59. “Country Churches and Service," PF 10 February 1917, 98; Herman Steen, "Coldbrook, a Forward-Looking Farm Community," PF 2 June 1917, 451; H. S. [probably Herman Steen], "Ellington Farmers Don't Move," PF 20 October 1917, 742; "Weak Churches Become Strong," PF 19 April 1919, 716; M. L. H. [Mabel L. Hughes], "Another Argument for Good Roads," PF 31 Jan 1920, 283, 300; "We Ought to have a Church for Funerals," PF 17 July 1920, 1751, 1757; “Gasolineless Sundays," PF 7 September 1918, 738; "The Preacher's Pay," PF 4 October 1919, 1592.

60. John F. Case, "When Women do the Work," MR 5 March 1916, 4; John F. Case, “How's Your Sunday School?" MR 5 September 1916, 9; John F. Case, untitled editorial, MR 5 April 1917, 3; John F. Case, "Where Folks Stay on the Farm, MR 20 September 1917, 1, 7; A. A. Jeffrey, "HarmonyThey Still do Things," MR 5 July 1919, 1, 7; A. A. Jeffrey, “A Farmers' Chautauqua," MR 5 January 1920, 10.

61. Report of the Country Life Commission, 8, 15, 16, 18, 19, 51, 54, 60-63.

62. Report of the Country Life Commission, 60.

63. Report of the Country Life Commission, 61-62.

64. "The Relation of the Country Pastor to Scientific Agriculture" WF 25 March 1910, 537-538; “The Farmer's Church," WF 12 May 1911, 802; “A Successful Rural Church," WF 11 August 1911, 1113.

65. Paul L. Vogt, ed., The Church and Country Life: Report of a Conference Held by the Commission on Church and Country Life under the Authority of the Federal Council of Churches of Christ in America. Columbus, Ohio. December 8-10, 1915 (New York: Missionary Education movement of the United States and Canada, 1916).

66. Robert T. Handy, ed. The Social Gospel in America, 1870-1920: Gladden, Ely, Rauschenbusch (New York: Oxford University Press, 1966), introduction; Ronald C. White and C. Howard Hopkins, The Social Gospel: Religion and Reform in Changing America (Philadelphia: Temple University Press, 1976); and Paul T. Phillips, A Kingdom on Earth: Anglo-American Social Christianity, 1880-1940 (University Park: Pennsylvania State University Press, 1996).

67. Winthrop S. Hudson, Religion in America: A Historical Account of the Development of American Religious Life, 3rd ed., (New York: Scribners, 1981), 302-304; Handy, 11-16; White and Hopkins, xviii.

68. Merwin Swanson, “The 'Country Life Movement' and the American Churches," Church History 46(3)(September 1977): 358-359; James H. Madison, "Reformers and the Rural Church, 1900-1950," Journal of American History 73(3)(December 1986): 646-647, 650.

69. Jacob Henry Dorn, Washington Gladden: Prophet of the Social Gospel (Columbus: Ohio State University Press, 1967), 373-374.

70. Phillips, xix; Robert T. Handy, Undermined Establishment: Church State Relations in America, 1880-1920 (Princeton: Princeton University Press, 1991) 104-107. 
71. Lucy Van Voorhis White, Dallas Center, Iowa, Circular letter to family, 4 February 1910, 26 February 1910, 15 Jun 1910, Lucy Van Voorhis White Papers, Correspondence, Outgoing, 1910-1911 and undated, Box 1, IWA. Emphasis in original.

72. Letters to WF: J. Y. Ashenhurst, 24 February 1911; Richmond A. Smith, 17 March 1911; A. G. Stewart, 16 June 1911, 956; C. R. Green, 16 June 1911, 947; D. Glenn Moore, 3 November 1911, 22; W. O. B., 24 November 1911, 1638; Eva K. Fickes, 22 March 1912, 5; D. C. Violet, 4 October 1912, 1397; D. W. Montgomery, 29 November 1912, 12; J. P. Campbell, 31 January 1913; P. H. Heisey, 19 September 1913, 8; J. F. Hinkhouse, 10 April 1914, 619; Bert McDonald, 10 April 1914, 629; E. E. Boyer, July 30, 1915, 1034.

73. “Mrs. N. S. G.," letter to WF 21 January 1910, 16.

74. D. W. Montgomery, letter to WF 29 November 1912, 12.

75. E. E. Boyer, letter to WF 30 July $1915,1034$.

76. Letters to WF: Rev. C. R. Green, 16 June 1911, 947; Rev. C. H. Culver, 25 August 1911, 15.

77. Letters to PF: Anna B. Taft, 1 March 1912, 16; Ray L. Carr, 15 March 1914, 284; N. H. Warren, 1 March 1912, 15. C. I. Hay's letter in opposition is treated below.

78. Letters to PF: “A Member," 8 March 1919, 430; “One Who Is in It, but Not of It," 8 March 1919, 430; Miss Alta M. Cook, 22 March 1919, 530; Mrs. M. V. S., 22 March 1919, 530, 532; M. Ruth Vial, 22 March 1919, 532, Mrs. W. G. Ransom, 22 March 1919, 532; Mrs. G. H., 22 March 1919, 532, N. H. Miller, 19 April 1919, 748; Edgar W. Smith, 19 April 1919, 748; Pearl A. Shields, 19 April 1919, 748-749; Bernard Hoelscher, 19 April 1919, 749; Ellen L. Burnap, 17 May 1919, 906-907. Letters to MR: Nadine S. Salmons, 5 June 1915, 5; Mrs. Arthur Wiley, 20 September 1919, 5; Nannie J. Knoch, 5 March 1916, 22-23; Mrs. D. E. Johnson, 5 February $1920,34$.

79. Letters to the Home Department, IH: "Mrs. Olive," 18 January 1912, 35; "Miss Michaelis," 18 January 1912, 35; "Mrs. Center Point," 15 February 1912, 40.

80. “Mrs. Center Point," letter to IH 15 February 1912, 40.

81. George S. Banta, letter to IH 28 January $1915,190$.

82. Unnamed correspondent quoted in editorial "The Country Preacher Needed," IH 11 May 1911, 1077.

83. "The Country Preacher Needed," IH 11 May 1911, 1077.

84. "The Use of the Country Church," WF 7 June 1912, 949; Mason Hatch, letter to WF 7 March 1913, 23-24.

85. M. L. Bibb, letter to WF 3 May 191, 805.

86. Rev. C. I. Hay, “The Preacher's Side of the Country Church Question," PF 1 February 1912, 11.

87. The theme of resistance is revealed by the name of Danbom's history, The Resisted Revolution; see also Bowers.

88. See Barron, Mixed Harvest, Kline, Consumers in the Country, and Neth, Preserving the Family Farm.

89. Swanson, 373; Madison, 665-668. 
90. Religious Bodies: 1926, v. 2 589-597; Finke and Stark, 202-216.

\section{NOTES TO CHAPTER SIX}

1. Jessie Field, “One Way to Help Your School," letter to WF 31 July 1908, 935.

2. Wayne Fuller, One-Room Schools of the Middle West: An Illustrated History (Lawrence: University Press of Kansas, 1994), 1; William H. Dreier, "A Brief History of Iowa's One-Room Schools," in Iowa's Country Schools: Landmarks of Learning, ed. William L. Sherman (Parkersburg, IA: Mid-Prairie Books, 1998), 3-10.

3. Wayne E. Fuller, The Old Country School: The Story of Rural Education in the Middle West (Chicago: University of Chicago Press, 1982); Danbom, "Rural Education Reform and the Country Life Movement," 462-464; Richard J. Jensen and Mark Friedberger, Education and Social Structure: An Historical Study of Iowa, 1870-1930 (Chicago: The Newberry Library, 1976), 7.1-7.5.

4. Reynolds, There Goes the Neighborhood, 59-61; James H. Madison, “John D. Rockefeller's General Education Board and the Rural School Problem in the Midwest, 1900-1930," History of Education Quarterly 24(Summer 1984): 191-194; Ellwood P. Cubberley, "State of Missouri" in A Cyclopedia of Education, Paul Monroe, ed., vol. 4 (New York: Macmillan, 1913), 271-276.

5. Ellwood P. Cubberley, "State of Illinois," in A Cyclopedia of Education, Paul Monroe, ed., vol. 3 (New York: Macmillan, 1912), 377-381.

6. Reynolds, There Goes the Neighborhood, 49-55; Fuller, The Old Country School, 185-217.

7. Danbom, The Resisted Revolution, 57-58.

8. Joseph Frazier Wall, Iowa: A Bicentennial History (New York: Norton, 1978), 186-187.

9. A. C. True, "Some Problems of the Rural Common School," in Yearbook of the United States Department of Agriculture 1901 (Washington, D. C.: Government Publishing Office, 1902), 133-154.

10. Danbom, "Rural Education Reform," 462-465.

11. Fuller, The Old Country School, 221-226.

12. Fuller, The Old Country School, 218-231; True, 143-148; Reynolds, There Goes the Neighborhood, 46-52; Theobald, Call School, 159-163; Danbom, The Resisted Revolution, 57-58. See also Keach Johnson, "Roots of Modernization: Educational Reform in Iowa at the Turn of the Century," The Annals of Iowa 50(8)(Spring 1991): 912-913 and Richard C. Barrett, Report of the Superintendent of Public Instruction, State of Iowa, 1901 (Des Moines: Department of Public Instruction, 1902), 30-45.

13. Report of the Country Life Commission, 6-7.

14. Report of the Country Life Commission, 17-18, 53-56.

15. Danbom, The Resisted Revolution, 14-15, 57; Bowers, The Country Life Movement in America, 79-80.

16. Reynolds, There Goes the Neighborhood, 49-84; Ellwood P. Cubberley, "Consolidation of Schools," in A Cyclopedia of Education, Paul Monroe, ed., vol. 2 (New York: Macmillan, 1911), 185-189. 
17. "Elementary Agricultural Teaching," IH 24 April 1896, 2.

18. "Agricultural Education in the Public Schools," WF 13 September 1895, 6.

19. "Teaching Agriculture in Country Schools," PF 14 January 1899, 11; “Teachers of Agriculture," MR 13 November 1902, 2. The Illinois bill failed to pass.

20. “Agriculture in Schools," IH 13 August 1897, 8; “Teaching Agriculture in Country Schools," PF 14 January 1899, 11; “The Teachings [sic] of Agriculture in the Public Schools," WF 14 September 1900, 889; "Agriculture in the Schools," IH 8 November 1900, 2; "Agriculture in Illinois Schools," WF 12 April 1901, 525; "Agricultural Instruction for Teachers," IH 28 January 1909, 145; "Course in Agricultural Education," IH 6 July 1911, 1325.

21. "Horticultural Education," IH 4 March 1898, 6; "Agriculture in Schools," IH 8 March 1900, 22; “Agricultural Instruction," IH 24 April 1902, 1; "Agricultural Education Idea Growing," IH 18 June 1903, 1; "Rural School Agriculture," IH 7 January 1904, 3; “Agriculture in the Schools," PF 15 February 1908, 99.

22. C. C. James, "Agriculture in Schools," IH 8 March 1900, 22; "Rural School Agriculture," IH 7 January 1904, 3; W. J. Spillman, “Teaching Agriculture in Public Schools," WF 25 December 1908, 1601; “Agriculture in High Schools," WF 28 October 1910, 1436; "Starting a Country School Nursery," PF 15 March 1911, 6; Otis Crane, "Farm Children take Hens to School," PF 15 June 1911, 7; “Agriculture in the Rural Schools," WF 4 May $1917,748$.

23. H. A. Crafts, "Study of Agriculture in Public Schools," IH 26 October 1911, 1917.

24. "Practical Rural Schools," WF 3 May 1918, 744. "Simple Soil Experiments," "Some Farm Arithmetic Problems," PF 1 October 1911, 31; "Farm Arithmetic Problems," PF 15 January 1913, 34.

25. "Agriculture in the Rural Schools," WF 26 March 1909, 472; "Raising a Crop of Young Farmers," IH 22 July 1909, 1209-1210; "Real Country Schools," IH 23 June 1910, 1223; "Making Real Country Schools," IH 11 August 1910, 1401, 1406; “Making Rural Schools Practical," IH 3 November 1910, 1889; "Improving the Country Schools," IH 22 January 1914, 174.

26. Jessie Field, "Agriculture in Country Schools," WF 20 December 1907, 1500; Henry A. Wallace, "A Day at the Coin School," WF 23 December 1910, 1718-1720; “A Good Rural School,” WF 18 November 1910, 1560. Field was the subject of a popular national magazine feature: W. K. Tate, "Country Schools for Country Children," The World's Work 24(1)(May 1912): 102-107. Her efforts in Page county were the beginning of 4-H clubs, which subsequently spread throughout the rural United States. See Janice Nahra Friedel, "Jessie Field Shambaugh: The Mother of 4-H," Palimpsest 62(4)(July/August 1981): 98-115.

27. “Model Country Schools of Winnebago County, Ill.," PF 1 May 1911, 5; Lulu G. Parker, "Giving the Country Children an Up-To-Date Education," PF 15 July 1912, 1-2; W. O. Brant, "Bettering the Country Schools," PF 1 December 
1912, 8. Kern was also the subject of a World's Work feature: “Common-Sense Country Schools," The World's Work 8(June 1904): 4881-4894.

28. F. B. Nichols, "Train Up A Child in the Way He Should Go," MR 5 July 1914, 3, 9; John F. Case, “The Work of A Woman," MR 5 July 1914, 4; John F. Case, "National Aid for the Porter School," MR 20 January 1917, 3; John F. Case, “'That Little Missouri School,"” MR 5 April 1920, 4. Evelyn Dewey, New Schools for Old: The Regeneration of the Porter School (New York: E. P. Dutton, 1919).

29. A. J. Jewell, “Agriculture in Common Schools," IH 22 January 1903, 8.

30. "The Rural Schools of the Corn Belt," WF 17 October 1913, 1404.

31. Rex Beresford, "Give the Farm Boy a Chance in the Country School," PF 1 April 1912, 11; "Children on the Farm," IH 18 April 1901, 1; “Appropriate Teaching in Rural Schools," IH 19 November 1903, 4. Danbom, The Resisted Revolution, 51-56; Fuller, The Old Country School, 221-226, Theobald, Call School, 163-176.

32. James M. Pierce, "Iowa Schools Do Much Good By Agricultural Courses," IH 19 August 1920, 2338-2339. "Agriculture in the Rural Schools," WF 4 May 1917, 748; "Practical Rural Schools," WF 3 May 1918, 744. A. A. Jeffrey, "Making Old Schools New," MR 5 June 1919, 21; John F. Case, "What Vocational Agriculture Means," MR 5 January 1920, 4; Paul W. Chapman, "Training Farm Boys at Home," MR 5 January 1920, 7, 25; Lee C. Stuart, "Here's the First Farm School," MR 20 February 1920, 8; A. A. Jeffrey, "It's the Doing that Counts," MR 5 March 1920, 7, 54.

33. "Concentration of the District School," WF 25 February 1898, 3; "Our Rural School Supplement," supplement to IH 26 December 1901; W. T. Carrington, "Rural Schools-II," MR 19 May 1904, 2; "Agricultural High Schools," PF 16 February 1905, 7.

34. "Making Better Country Schools," IH 29 October 1903, 4; "The Education of the Farmer Boy," IH 5 November 1903, 4; “The Pay of Rural Teachers," IH 17 December 1903, 4; "Reform in Rural Schools," IH 8 December 1904, 1681; C. F. Curtiss, "The Rural-Education [sic] Problem," IH 5 January 1911, 11-12.

35. “The One-Room School Menace," IH 5 June 1913, 1051, 1059.

36. F. Neville, "Graded School in Rural Districts," IH 7 October 1915, 1739.

37. Artie McDonald, “Agriculture in Rural Schools," MR 5 August 1911, 3.

38. John F. Case, "Consolidation Failure and Success," PF 20 October 1916, 4; John F. Case, "A Square Deal for Children, MR 5 March 1919, 4; "Farm Children Schooled at Home," MR 20 April 1919, 3, 15.

39. “Model Country Schools of Winnebago County, Ill.," PF 1 May 1911, 5; "A Farm Community Where Everyone is Happy," PF 1 October 1911, 5, 32; Lulu G. Parker, "Giving the Country Children an Up-To-Date Education," PF 15 July 1912, 1-2; Arthur J. Bill, "Up-to-Date Education for Country Children," PF 1 December 1913, 15; Margaret Moody, “Twelve Years Experience With Consolidated Schools," PF 14 August 1915, 561, 577; Mabel Hughes, "The Story of Stonington High School," PF 5 June 1920, 1443, 1470; Mabel Hughes, "The Community and the High School," PF 17 July 1920, 1709, 1728. 
40. "Concentration of the District School," WF 25 February 1898, 3; “Country Schools" WF 12 April 1901, 524.

41. “The Central School House Plan," WF 15 June 1900, 619.

42. “The Centralized School System," WF 15 March 1901, 371.

43. "Country Schools," WF 22 March 1901, 406; "Carrying Children to Consolidated Schools," WF 10 March 1905, 333; “Our Country Schools," WF 10 May 1907, 602.

44. "The Centralized School in Indiana," WF 17 April 1908, 559; "An Illinois Consolidated School," WF 31 May 1907, 683.

45. "Agriculture in the Rural School," WF 15 December 1908, 1564; "The Iowa School Laws," WF 15 January 1909, 75.

46. “What Drives Farmers to Town," WF 20 August 1909, 1025.

47. "Centralized Schools," WF 24 February 1911, 329; “The Iowa Rural Schools," WF 11 February 1910, 242. See also "Rural Midwesterners Respond" below.

48. "Where Should Consolidated Schools be Located," WF 17 April 1914, 661; "Consolidated Schools," WF 23 February 1917, 341; "A Rural Consolidated School," WF 8 February 1918, 227; C. R. Hoffer, “A School that Meets Community Needs," WF 7 May 1920, 1310; Macy Campbell, “Consolidated Schools," WF 16 July 1920, 1758.

49. W. T. Carrington, "Rural Schools-II," MR 19 May 1904, 2.

50. "Consolidation of Rural Schools," IH 17 May 1906, 803; Margaret Moody, "Twelve Years Experience With Consolidated Schools," PF 14 August 1915, 561, 577; C. J. Collingsworth, "The Consolidated School," WF 19 January 1917, 108.

51. "Grading Country Schools," IH 8 January 1903, 4; "Rural School Conditions," IH 30 April 1903, 4; “Consolidation of Rural Schools, IH 5 January 1905, 6.

52. Fred H. Rankin, "Consolidation of Country Schools," IH 9 March 1905, 411; Fred H. Rankin, "Consolidation of Country Schools," IH 13 April 1905, 650; "Consolidating Schools," IH 12 January 1911, 68-69; C. F. Curtiss, "The Rural-Education [sic] Problem," IH 5 January 1911, 11-12.

53. Macy Campbell, “The Children Pay the Price," IH 22 May 1919, 1394-1396, "What Killed the Rural School?" WF 6 June 1919, 1179, "New Rural School in Orange Township," IH 26 February 1920, 841, "Housing Consolidated Schools," IH 3 June 1920, 1842, "The Consolidated School," WF 18 June 1920, 1625, and "Consolidated Schools," WF 16 July 1920, 1758.

54. Danbom, The Resisted Revolution, 57-58; Bowers, 80-82; Barron, 56, 63.

55. Macy Campbell, "The Children Pay the Price," IH 22 May 1919, 1394-1396; Macy Campbell, "New Rural School in Orange Township," IH 26 February 1920, 841, 860-861; “Consolidation of Schools," IH 13 May 1920, 1654-1655; Macy Campbell, "Housing Consolidated Schools," IH 3 June 1920, 1842; “Educating Farm Children," IH 2 September 1920, 2441. "Consolidated Schools," WF 23 February 1917, 341; "How to Consolidate," WF 23 March 1917, 532; “A Rural Consolidated School," WF 8 February 1918, 227; Macy Campbell, "What Killed the Rural 
School?" WF 6 June 1919, 1179; “The Consolidated School,” WF 11 June 1920, 1563; Macy Campbell, "The Consolidated School," WF 18 June $1920,1625$.

56. J. Peasley, "Our Rural Schools," IH 4 March 1909, 492; “Modern Rural Schoolhouses," IH 2 December 1909, 2002-2003; “Why Country Schools are Backward," PF 1 March 1911, 24; “To Check Rural Population Loss," MR 3 February 1912, 4; John R. Kirk, "Children Better than Cattle," MR 3 August 1912, 3, 6; "How About the School Housc," PF 15 Scptcmber 1914, 606; “Improved Schoolhouse Plans," IH 5 December 1918, 4033; Chesla C. Sherlock, "Playing Square with Your Schools," IH 22 April 1920, 1472-1473.

57. Mrs. S. M. Cade, "Education of Children on the Farm," IH 31 January 1896, 9; “The Parent-Teachers' Association," WF 27 September 1912, 18; "What Parents Can Do for the School," PF 1 October 1912, 26; "Your School Teacher," PF 11 March 1916, 266; John F. Case, "Let's Get Behind 'Teacher," MR 5 October 1918, 4.

58. "A Word to School Directors," WF 6 March 1908, 338; "Care in Selecting County Superintendents," WF 20 May 1910, 805; "County Superintendents," WF 28 October 1910, 1432; John F. Case, "An Important Election," MR 5 April 1916, 4; James M. Pierce, “The Country School," IH 26 August 1915, 1471.

59. “Country Schools," IH 28 August 1902, 6; W. T. Carrington, "Missouri School Notes," MR 15 March 1906, 7; "Engage the Best Teachers for the Country Schools," WF 16 August 1907, 898; "Rural School Incompetency," IH 26 January 1911, 197; "Picking Out a Country Teacher," PF 15 August 1911, 12; “The Truth about Teachers," MR 5 February 1920, 4.

60. "The Scarcity of Teachers in the Rural Schools," WF 10 May 1901, 648; "The Pay of Rural Teachers," IH 17 December 1903, 4; W. T. Carrington, “Missouri School Notes," MR 15 March 1906, 7; “Teachers are Poorly Paid," IH 2 December 1909, 2000; “Teachers and Their Wages," IH 16 December 1909, 2104; "Scarcity of Teachers," WF 3 October 1913, 1348; "The Wages of School Teachers," WF 3 December 1915, 1596; "Salaries of School Teachers," WF 10 November 1916, 1464; John F. Case, "We Face a Teacher Famine," MR 20 February 1918, 15; James M. Pierce, "A Good Education is a Splendid Investment," IH 12 February 1920, 650.

61. "Rural Schools as Social Centers," IH 5 October 1911, 1740; "Unlock the Schoolhouse Door," IH 1 May 1913, 908; James M. Pierce, "Open the Schoolhouses," IH 13 November 1913, 1821; "Rural Social Life," PF 1 January 1914, 18; John F. Case, "Why Darken the Schoolhouse?" MR 5 December 1916, 3; “The School a Social Center," IH 21 June 1917, 1058. "Community Centers with Consolidated Country Schools," WF 8 July 1910. 987; "The Consolidated School as a Social Center," WF 24 March 1911, 23.

62. "Wisconsin's Agricultural Schools," MR 15 January 1903, 3; C. K. Davis, "County Schools of Agriculture," MR 29 October 1903, 3; Angeline Wood, "What County Schools of Agriculture Do for Young Women," MR 
29 October 1903, 3; "County Agricultural Schools," IH 24 November 1904, 1601; Dick J. Crosby, "Agricultural High Schools," IH 7 July 1910, 1280; "Agricultural High School," IH 13 October 1910, 1746; Alice W. Beatty, “The County Agricultural High School," WF 18 February 1916, 264.

63. Barron, 76-77.

64. Letters to WF: Frank C. Pellett, 1 April 1904, 493; A. B. F. Parsons, 25 October 1907, 1217; Arthur D. Cromwell, 27 December 1907, 1500; Cap E. Millcr, 16 October 1908, 1261; Arthur D. Cromwell, 29 April $1910,719$.

65. Letters to WF: Jessie Field, 31 July 1908, 935; Alice Leech, 3 February 1911, 171; M. A. Chary, 15 March 1918, 494.

66. John G. Osborn, letter to WF 27 September 1907, 1067.

67. Ada B. F. Parsons, letter to WF 19 February 1915, 314.

68. "C. C. C.," letter to $I H 30$ October 1913, 1751-1752; S. B. McCollum, letter to MR 20 July $1912,5$.

69. W. A. Estes, letter to $I H 27$ January 1916, 198; Letter to MR: F. W. York, 5 October 1912, 5 .

70. Fuller, The Old Country School, 224-226; Danbom, The Resisted Revolution, 76-80; True, 148-151.

71. James M. Pierce, "Laying School Blame on the Farmer," IH 2 December $1915,2087$.

72. "The Country School Problem," IH 6 January 1916, 8-10.

73. Letters to $I H$ : "Hardin County Farmer," 6 January 1916, 8; "A Reader," Marshalltown, Iowa, 6 January 1916, 8-9; W. A. Estes, 27 January 1916, 198; B. E. Bigelow, 24 February 1916, 470; "An Old Subscriber," 9 March 1916, 590; "A Mother," 23 March 1916, 702; "A Subscriber," 30 March 1916, 753; “E. E. M.,” 1 June 1916, 1162.

74. C. R. Riley, letter to IH 20 January 1916, 138.

75. "Consolidation of Rural Schools," IH 17 May 1906, 803; Margaret Moody, "Twelve Years Experience With Consolidated Schools," PF 14 August 1915, 561, 577; C. J. Collingsworth, "The Consolidated School," WF 19 January 1917, 108.

76. Letters to $I H$ : "Hardin County Farmer," 6 January 1916, 8; "Mrs. L. L. L.," 24 February 1916, 470; "A. W. A.," 16 March 1916, 646; H. G. Gast, 30 March 1916, 752; "A Subscriber," 30 March 1916, 753; "A Mother Taxpayer," 20 April 1916, 897.

77. Reynolds, There Goes the Neighborhood, 72-84, 121-130. "An Old Subscriber," letter to IH 9 March 1916, 590. "Where Should Consolidated Schools be Located," WF 17 April 1914, 661. Letters to IH: W. A. Estes, 27 January 1916, 198; John Bock Jr., 24 February 1916, 470; “A Mother," 23 March 1916, 646; “A Subscriber," 30 March 1916, 753; Mrs. R. E. James, 27 April 1916, 944; G. A. Hunter, 11 May 1916, 1024; “E. E. M.," 1 June 1916, 1162.

78. Letters to $I H$ : “A Reader," 6 January 1916, 8; C. R. Riley, 20 January 1916, 138; B. E. Bigelow, 24 February 1916, 470; “An Old Subscriber," 9 March 1916, 590; "A Subscriber," 30 March 1916, 753. Bigelow cited Abraham 
Lincoln, Thomas Edison, and Diogenes (!) as examples of successful ruraleducated men.

79. Letters to IH: W. A. Estes, 27 January 1916, 198; “Mrs. L. L. L.," 24 February 1916, 470; John Bock Jr., 24 February 1916, 470; “A. W. A.,” 16 March 1916, 646; “A Mother Taxpayer,” 20 April 1916, 897.

80. “S. M. L.," letter to IH 16 March 1916, 648.

81. Letters to IH: "S. M. L.," 16 March 1916, 648; "Subscriber," 23 March 1916, 704; Supt. E. B. Hodges, 13 April 1916, 876; Supt. B. F. Clarke, 27 April 1916, 963; Mrs. W. C. Griffith, 8 June 1916, 1190; Supt. A. W. Phillips, 8 June 1916, 1190.

82. J. H. Matthew, letter to PF 6 March 1920, 670.

83. Letters to PF in opposition to consolidation: J. H. Matthew, 6 March 1920 , 670; Delmar Byard, 3 April 1920, 970; Charles E. Strode, 10 April 1920, 1040; Lee R. Blae, 10 April 1920, 1040-41; Jesse W. Osborn, 1 May 1920, 1212. Letters to $P F$ in support of consolidation: John C. Gummersheimer, 10 April 1920, 1044-45; O. Glen Poland, 17 April 1920, 1096.

84. “L. L..," letter to WF 2 May 1902, 661.

85. Letters to WF: S. P. Baird, 6 July 1900, 688; “Aunt Anna,” 6 July 1900, 683; Emma L. Terhune, 30 November 1900, 1184; "H," 14 March 1902, 388; E. S. Miles, 21 March 1902, 438; “L. L.," 2 May 1902, 661; E. A. Whisler, 16 May 1902, 731; John G. Osborn, 27 September 1907, 1067.

86. Letters to WF: W. P. George, 6 September 1901, 1082; W. M. Purce, 31 January 1902, 155; A. L. Harris, 21 August 1914, 1148; I. W. Dayton, 23 February 1917, 364.

87. Letters to WF: I. W. Dayton, 23 February 1917, 364, E. D. Michael, 23 February 1917, 364, L. W. Collins, 23 February 1917, 364-365, Fred F. Beebee, 23 February 1917, 365-366, A. B. Adams, 23 February 1917, 366, W. A. Robinson, 23 March 1917, 530-532.

88. W. C. Collingsworth, letter to WF 5 June 1914, 888.

89. W. A. Robinson, letter to WF 23 March 1917, 530-532.

90. J. F. Abel, Consolidation of Schools and Transportation of Pupils, Department of the Interior, Bureau of Education, Bulletin No. 41 (Washington, D. C.: Government Printing Office, 1923), 56; Timon Covert, Rural School Consolidation: A Decade of School Consolidation with Detailed Information from 105 Consolidated Schools, United States Department of the Interior, Office of Education, Pamphlet No. 6 (Washington, D. C.: Government Printing Office, 1930), 3.

91. Barron, 76-77.

92. Madison, “John D. Rockefeller's General Education Board,” 181, 191-195; Danbom, The Resisted Revolution, 76-81; Fuller, The Old Country School, 234-244; Barron, 56-60, 66-73.

93. Barron, 37-42, 76-77.

94. Paul Theobald, Call School, 153-183; also "Democracy and the Origins of Rural Midwest Education: A Retrospective Essay," Educational Theory 38(3)(Summer 1988): 363-367.

95. Reynolds, There Goes the Neighborhood, 8. 
96. Reynolds, There Goes the Neighborhood, 138-223.

\section{NOTES TO CHAPTER SEVEN}

1. “Why Leave the Farm?" MR 20 March 1915, 1.

2. E. E. Buck, "Husband and Wife," PF 14 April 1900, 10.

3. "Keep the Boys and Girls on the Farm," WF 3 February 1905, 137.

4. James A. Henretta, "Families and Farms: Mentalité in Pre-Industrial America," William and Mary Quarterly 35(1)(January 1978): 3-32; John Mack Faragher, "History from the Inside-Out: Writing the History of Women in Rural America," American Quarterly 33(5)(1981): 537-557; Faragher, Sugar Creek, 79-118; Fink, Open Country, Iowa; Pederson, Between Memory and Reality; Neth, Preserving the Family Farm; Sally McMurry, Transforming Rural Life: Dairying Families and Agricultural Change, 1820-1885 (Baltimore: Johns Hopkins University Press, 1995); Nancy Grey Osterud, Bonds of Community: The Lives of Farm Women in Nineteenth-Century New York (Ithaca: Cornell University Press, 1991).

5. Mary Neth, "Gender and the Family Labor System: Defining Work in the Rural Midwest," Journal of Social History 7(3)(Spring 1994): 563-577; Neth, Preserving the Family Farm, 17-39; Marilyn Irvin Holt, Linoleum, Better Babies \& the Modern Farm Woman, 1890-1930 (Albuquerque: University of New Mexico Press, 1995), 16-18; Aley, 454-458.

6. "Modern Conveniences in Farm Homes," WF 21 January 1910, 6.

7. “Modern Conveniences in Farm Residences," IH 16 June 1904, 896; "Freeing the Farm Wife," IH 31 August 1911, 1539; "Machinery in Women's Work," IH 17 December 1914, 2080; “The Farm Woman's Remuneration-Less Work," IH 22 April 1915, 861.

8. “Conserving Mother's Strength," PF 23 September 1916, 744.

9. Alta Hooper, "Making Life Pleasant for the Women Folks," PF 15 November 1913, 7, 19; "The Man Who is Good to His Wife," PF 3 June 1916, 494; “Mother's Share," PF 18 November 1916, 884; “The Farmer's Wife," MR 24 February 1910; Bab Bell, "Give Women a Share: Labor Saving Devices Help Make a Successful Home," MR 5 March 1914, 8; Bab Bell, "Why the Tired Feeling?: Labor Saving Appliances Mean More Leisure for Farm Women" MR 20 June 1914, 8.

10. Holt, 3-4.

11. "Education for Girls," WF 14 October 1898, 766; “Domestic Economy in Agricultural Schools," PF 29 January 1898, 2; Mary Blodgett, "Home Economics Important Course in Rural Schools," PF 1 September 1911, 5, 27; chapter six also notes farm newspapers' support for the teaching of domestic science in rural schools.

12. Bab Bell, "Are You A Homemaker?" MR 5 February 1914; Bab Bell, "A Well Fed Family" MR 5 May 1914, 8; "Clean Up, Avoid Disease: Filth and Flies are First Aids to Fever," MR 20 February 1915, 10.

13. "Love and Domestic Science," PF 1 July 1911, 12.

14. "Housekeeping as a Business," PF 25 June 1898, 10; "Household Accounts," PF 17 December 1898, 10; Margaret Palmer, "Have You A Card 
Index?" MR 20 April 1916, 10; Stella G. Nash, "Partnership in the Home," MR 20 June 1919, 4.

15. "Women and Chickens," WF 12 May 1905.

16. “The Woman's Task," WF 2 February 1912, 17.

17. Quote from R. B. Rushing, "Poultry as a Side Issue on the Farm," IH 1 February 1912, 3. May Wright, "Business for Farmers' Wives," PF 16 June 1900, 15; Mrs. Louie E. Fletcher, "How Women and Girls May Become Self-Supporting," IH 12 December 1901, 23; "Women as Poultry Raisers," MR 3 December 1903, 14; “A Successful Poultry Woman," WF 5 August 1904, 974; Mrs. Charles Jones, “Turkey Raising for Women," PF 2 February 1905, 12; Mrs. S. B. Titterington, "How One Woman Saved the Day," IH 29 August 1907, 1136; "The Male Man and the Female Hen," WF 16 June $1911,5$.

18. “The Farm Wife's Work," WF 16 July 1920, 1754. See Fink, Open Country, Iowa, 135-160.

19. E. E. Buck, "Husband and Wife," PF 14 April 1900, 10.

20. Quote from John F. Case, "Make Her A Partner," MR 20 March 1914, 4. F. B. Nichols, "Why Not Make Your Wife a Partner," MR 5 August 1914, 3; "A Partnership Affair," MR 20 September 1915, 11; Stella G. Nash, "Partnership in the Home," MR 20 June 1919, 4; "Woman's Life on the Farm," IH 21 April 1910, 907; “The Worn-Out Woman," WF 15 December 1911, 22.

21. Mrs. A. J. Wilder, "A Homemaker of the Ozarks," MR 20 June 1914, 3.

22. "Women Find Farming Pays," PF 15 September 1910, 16; C. C. Bowsfield, "Women Manage 40 Acre Farm Successfully," PF 1 February 1912, 17.

23. "Some Real Women Farmers," WF 16 August 1918, 1159.

24. "Women as Farmers," IH 28 March 1901, 3; "Farming for Women," IH 27 May 1909, 994.

25. “The Divorce Evil," WF 6 October 1911, 8; "The Preservation of Home Life," IH 16 April 1903, 4; "Moral Reforms Due to Farmer," IH 20 May 1909, 961; Albert S. Ennis, "Serious Problems of Life," MR 6 January 1910, 6.

26. Deborah Fink, Agrarian Women: Wives and Mothers in Rural Nebraska, 1880-1940 (Chapel Hill: University of North Carolina Press, 1992).

27. Report of the Country Life Commission, 46-47.

28. Holt, 4-11; Dorothy Schwieder, 75 Years of Service: Cooperative Extension in Iowa (Ames: Iowa State University Press, 1993), 20-34, 47-57.

29. Garvey, The Adman in the Parlor.

30. Neth, Preserving the Family Farm, 187-243; Katherine Jellison, Entitled to Power: Farm Women and Technology, 1913-1963 (Chapel Hill: University of North Carolina Press, 1993), 33-66; see also Fink, Open Country, Iowa, 19-44.

31. “A Farmer's Wife," letter to WF 23 August 1912, 16.

32. Cora B. Hillis, letter to WF 10 May 1895, 2; Letters to $I H$ : Mrs. A. F. Sorensen, 25 July 1907, 1008; Mrs. S. B. Titterington, 9 November 1911, 2012-13; “S. E. M.," 10 February 1916, 358; F. W. Kazmeier, letter to PF 1 October 1912, 20-21. 
33. Mrs. Theodore Saxon, letter to WF 9 Jan 1920, 94.

34. “Farmer Bachelor Girl," letter to MR 4 December 1902, 9.

35. L. E. Honnold Bellows, letter to IH 22 February 1895, 9; "Farmer Bachelor Girl," letter to MR 4 December 1902, 5; “A Woman," letter to IH 15 April 1909, 803; “A Reader," letter to WF 18 February 1910, 32; Jellison, 32.

36. G. H. Campbell, letter to PF 14 August 1915, 558; Letters to MR 20 April 1914, 6: Mrs. M. A. Logan, Mrs. T. D. Jones, Mrs. L. Brockman, Mrs. A. E. Thurber, “Mrs. H. N. F.," Mrs. S. V. Norton, "V. M."

37. Danbom, The Resisted Revolution, 86-96; Neth, Preserving the Family Farm, 187-196, 227-236; Jellison, Entitled to Power, 33-66.

38. Holt, 51-64; Schwieder, 75 Years of Service, 47-57; Dorothy Schwieder, “The New Rural History: A Subject Whose Time Has Come," The Historian 58(4)(Summer 1996): 848-849; Barron, Mixed Harvest, 193-242; Pamela Riney-Kehrberg, "Women, Technology, and Rural Life: Some Recent Literature," Technology and Culture 38(4)(October 1997): 943-953.

39. Many twentieth-century women embraced labor-saving household technology only to find no reduction in their work because societal expectations for housework increased. Ruth Schwartz Cowan, More Work for Mother: The Ironies of Household Technology from the Open Hearth to the Microwave (New York: Basic Books, 1983).

40. Sinnema, "Dutch American Newspapers;" Anderson, Imagined Communities; Passett, Sex Radicals and the Quest for Women's Equality.

41. “Among Ourselves," IH 4 January 1895, 10; “Among Ourselves," IH 8 March 1895, 10; “Among Ourselves," IH 18 October 1895, 10; "Editorial Announcement," IH 6 May 1898, 10; “With the Editor," IH 6 May 1898, 10; "With the Editor," IH 2 January 1913, 30; “Among Ourselves," IH 2 January 1913, 30, 32; IH 6 January 1916.

42. WF 8 January 1897, 8; "Daughters of Ceres," WF 22 January 1897, 10; "Daughters of Ceres," WF 19 February 1897, 12; "Three Cheers for Fredonia Chapter No. 1," WF 26 March 1897, 10; “Daughters of Ceres," WF 17 September 1897, 8. Records from the Des Moines Chapter of the Daughters of Ceres, founded in 1898, are available in the Iowa Women's Archives. Daughters of Ceres Records, IWA.

43. Pamela Riney-Kehrberg, "Helping Ma and Helping Pa: Iowa's Turn-of-theCentury Farm Children," The Annals of Iowa 59(2)(Spring 2000): 115-140; Neth, Preserving the Family Farm, 20-25, 158-159; Elliot West, Growing Up With The Country: Childhood on the Far Western Frontier (Albuquerque: University of New Mexico Press, 1989), 73-98; Viviana A. Zelizer, Pricing the Priceless Child: The Changing Social Value of Children (Princeton: Princeton University Press, 1994).

44. Pamela Riney-Kehrberg, "Farm Childhood and Life Choices: The American Midwest, 1870-1920," paper presented at the Organization of American Historians Midwestern Regional Conference, Ames, Iowa, 5 August 2000.

45. See chapter five.

46. "Boys on the Farm," IH 14 March 1901, 6. 
47. "The Boys Leaving the Farm," IH 26 January 1899, 3; "Keeping Boys on the Farm," IH 20 November 1900, 3; "Justice to the Boys," IH 15 September 1904, 1251.

48. "Why Boys Leave the Farm," WF 9 October 1903, 1316. Compare this to William Jennings Bryan's "Cross of Gold" speech at the 1896 Democratic Convention: "Burn down your cities and leave our farms and your cities will spring up again as if by magic; but destroy our farms and the grass will grow in the streets of every city in the country." Donald K. Springen, William Jennings Bryan: Orator of Small-Town America (New York: Greenwood Press, 1991), 138.

49. Henry Wallace, “The Farm Boy and His Future Business," WF 15 July 1897, 2. This editorial was one in a series of "Letters to the Farm Boy," published in 1897. The series was later published in book form and the volume was republished by national publisher MacMillan: Henry Wallace, Letters to the Farm Boy, 3d ed. (New York: MacMillan, 1900).

50. G. W. Clark, “To Farmers' Boys," PF 18 August 1900, 3.

51. "Talks with Farmers' Boys-I," MR 25 December 1902, 9; "From Farm to City," IH 12 June 1902, 30.

52. "Children on the Farm," IH 18 April 1901, 1.

53. Rex Beresford, "Give the Farm Boy a Chance in the Country School," PF 1 April 1912, 11.

54. "Give the Boys a Chance," PF 15 March 1912, 12; "What about the Boy?" IH 24 February 1910, 460; "Keeping the Boys on the Farm," IH 24 March 1910, 700; “Why do Boys and Girls Leave the Farm?” WF 28 January 1910, 122; "Getting the Boy Started Right," WF 26 August 1910, 1115.

55. James M. Pierce, “Cheating the Farm Boy,” IH 29 July 1915, 1347.

56. "The Farm Raised Boy," IH 16 May 1908, 882; Warren H. Wilson, "Conservation of Boys," MR 17 February 1910, 3.

57. Charles W. Farr, "One Way of Keeping Boys Satisfied on the Farm," PF 18 May 1905, 1; "Keeping Boys and Girls on the Farm," IH 2 June 1909, 1034.

58. "Fun on the Farm," IH 20 June 1901, 6; George W. Brown, "One Way to Keep Boys on the Farm," PF 15 April 1910, 7.

59. Aunt Belle, “The Girl at Home," PF 27 March 1897, 11; "Talks With Girls," MR 15 January 1903, 5; Alma Z. Moore, “The Lure of the Farm Home," MR 9 July 1910, 3, 15; Alma Z. Moore, "The Career of the Country Girl," MR 4 May 1912, 12.

60. “Is Your Daughter Protected?" $P F 1$ April 1910, 24; "Country Girls Coming to the City," WF 20 November 1914, 1533; “The Country Girl," WF 16 April 1915, 646.

61. “Talks with Farmers' Daughters," MR 8 January 1903, 5; “Getting the Boy Started Right," WF 26 August 1910, 1115; "Teaching the Farm Girl to Cook," IH 13 March 1913, 571; “The Country Girl,” WF 16 April 1915, 646; "Educate the Farm Girl," WF 15 October 1915, 13.57.

62. “About Farmers' Daughters," MR 25 December 1902, "Why Do Boys and Girls Leave the Farm?" WF 28 January 1910, 122; 5; John F. Case, "Keeping Girls on the Farm," MR 25 October 1913, 4; Annie H. Bauer, 
"Give the Girls a Chance," MR 5 May 1914, 9; "Why Country Girls Come to the City," WF 1 January 1915, 6.

63. Warren H. Wilson, "The Girl on the Farm," PF 15 October 1911, 22.

64. "Keep the Boys and Girls on the Farm," WF 3 February 1905, 137; "Why Do Boys and Girls Leave the Farm?" WF 28 January 1910, 122; “The Country Girl in the City," WF 22 March 1912, 5.

65. John F. Case, “Keeping Girls on the Farm," MR 25 October 1913, 4.

66. “About Farmers' Daughters," MR 25 December 1902, 5.

67. Report of the Country Life Commission, 65; Pamela Riney-Kehrberg, "Farm Childhood and Life Choices."

68. F. W. Zimmerman, letter to IH 3 July 1902, 20.

69. J. H. Kiplinger, letter to $M R 28$ January 1904, 3; “T.," letter to WF 9 February 1912, 260; G. H. Campbell, letter to PF 14 August 1915, 558; W. A. Graham, letter to IH 13 April 1916, 877.

70. “A Young Farmer," letter to WF 18 December 1903, 1653.

71. "Road Overseer," letter to IH 30 March 1899, 19; A. W. W., letter to $M R$ 24 November 1904, 2; Lloyd Hansen, letter to WF 31 March 1905, 461; Ernest Noteboom, letter to WF 25 October 1907, 1222; Leo Ahart, letter to IH 8 June 1911, 1221.

72. Letters to WF: Mrs. C. E. Fuller, 28 January 1898, 10; F. R. Y., 2 October 1903, 1291; "Subscriber," 6 November 1903, 1461;

73. Letters to WF: Mrs. C. E. Fuller, 28 January 1898, 10; Arthur D. Cromwell, 10 April 1908, 536.

74. Danbom, Born in the Country, 161-184; Hurt, American Agriculture, 221-277.

75. Riney-Kehrberg, "Farm Childhood and Life Choices"; Franklin Yoder, "Diverging Paths: Progressive Elites and Immigrants in the Post-Frontier Midwest," paper presented to the Newberry Seminar in Rural History, Chicago, 4 December 1999.

76. "How to Drive the Boy from the Farm," WF 4 May 1906, 605.

\section{NOTES TO CONCLUSION}

1. Mary Neth gives a good description of agricultural institutions, but she sees farm newspapers as basically one of them. Preserving the Family Farm, 97-121, 188-192, 227-230.

2. Bernard C. Cohen quipped, "[the press] may not be successful much of the time in telling people what to think, but it is stunningly successful in telling its readers what to think about." Bernard C. Cohen, The Press and Foreign Policy (Princeton: Princeton University Press, 1963), 13. Emphasis in original.

3. Maxwell E. McCombs and Donald L. Shaw, "The Agenda-Setting Function of Mass Media," Public Opinion Quarterly 36(2)(Summer 1972): 176-187; Roger W. Cobb and Charles D. Elder, Participation in American Politics: The Dynamics of Agenda-Building (Boston: Allyn and Bacon, 1972); McCombs and Shaw, "The Agenda-Setting Function of the Press" in The Emergence of 
American Political Issues: The Agenda-Setting Function of the Press, McCombs et al., eds., (St. Paul: West Publishing, 1977), 1-18; David L. Swanson, "Feeling the Elephant: Some Observations on Agenda-Setting Research," in Communication Yearbook 11 (Newbury Park, Ca: Sage Publications, 1988), 603-619.

4. Stuart William Shulman, "The Origin of the Federal Farm Loan Act: Agenda-Setting in the Progressive Era Print Press," (Ph. D. diss., University of Oregon, 1999).

5. A critique is James S. Ettema et al., "Agenda-Setting as Politics: A Case Study of the Press-Public-Policy Connection," Communication 12(2)(1991): 75-98. Broadened analyses include Everett M. Rogers and James W. Dearing, "Agenda-Setting Research: Where Has it Been, Where is it Going?" in Communications Yearbook 11, 555-594; and James W. Dearing and Everett M. Rogers, Agenda-Setting (Thousand Oaks, Ca: Sage Publications, 1996).

6. James W. Carey, Communication as Culture: Essays on Media and Society (New York: Routledge, 1992), 13-36, quote from p. 19-20.

7. Leonard, News for All, 117-146.

8. Vaught, "State of the Art-Rural History," 764.

9. Demaree, The American Agricultural Press, 231-236.

\section{NOTES TO EPILOGUE}

1. Evans and Salcedo, 170.

2. Socolofsky, "The Development of the Capper Farm Press," 39-40; Socolofsky, Arthur Capper, 135-142.

3. Evans, Prairie Farmer and WLS, 62-65, 72-78.

4. Smith, "The Iowa Homestead," 240-241; Thompson, "Wallaces' Farmer," 254-255; Murphy, "The Centennial of a Farm Paper," 468-475.

5. Evans, Prairie Farmer and WLS, 79; Murphy, "Centennial of a Farm Paper," 475-476; Evans and Salcedo, 170.

6. Mass circulation weekly magazines like Life and the Saturday Evening Post declined for the same reasons, just a short time later. Leonard, News for All, 168-176.

7. Evans and Salcedo, 65-87, 195. In 1959, the "Iowa Homestead" portion of the name was dropped, and the apostrophe that followed the " $\mathrm{s}$ " on Wallaces was also removed. "A Brief History of Wallaces Farmer," pamphlet from Farm Progress Companies (Des Moines: n. d.); Bowker's News Media Directory, 54th ed. (New Providence, N. J.: Bowker, 2004), vol. 2, 5-14.

8. Evans, Prairie Farmer and WLS, 168-175.

9. "A Brief History of Prairie Farmer."

10. "A Brief History of Wallaces Farmer."

11. "Rural Press Limited," available from http://www.ruralpress.com.au/index. html; Internet; accessed 22 September 2004. "Farm Progress," available from http://www.farmprogress.com; Internet; accessed 22 September 2004.

12. Bowker's News Media Directory, 54th ed., vol. 2, 5-1 to 5-26; Evans and Salcedo, 170. 
Page Intentionally Left Blank 


\section{Bibliography}

\section{PRIMARY SOURCES}

Manuscript Sources

\section{EARL W. HAYTER REGIONAL HISTORY CENTER, NORTHERN ILLINOIS UNIVERSITY, DEKALB, ILLINOIS}

Baldwin Family Papers

Laura Cooper Collection

Denton Family Papers

Friends in Council Papers

Gurler Family Papers

Hall Family Collection

Johnson Family Records

Jolly Neighbors Club Papers

Harry A. Joslyn Collection

Guy Lanan Farm Records

The Lovering Collection

Nisbet Homestead Farm Records

Norris Family Collection

Henry H. Parke Collection

Settle Farm Day Book

Ella Hume Taylor Collection

Vanderhoof Family Collection

Woodbury-Forsythe Diaries

\section{ILLINOIS STATE HISTORICAL LIBRARY, SPRINGFIELD, ILLINOIS}

John Campbell Bailey Diaries (These diaries are owned by the Rock Island Historical Society, and a copy is held by the Illinois State Historical Library)

Barrackman-Rowe Family Papers

Samuel Carpenter Diaries 
Arthur D. Fowler Papers

Henry A. Griswold Family Papers

John H. Manny Papers

Brown Munro Papers

Lois Tucker Orr Diaries

Jacob W. Ryner Family Papers

Safford Family Papers

John Sprecher Papers

Jonathan Baldwin Turner Papers

Carl Schurz Vrooman Papers

Edwin E. Warren Diaries

John E. Young Diary

\section{IOWA WOMEN'S ARCHIVES, UNIVERSITY OF IOWA LIBRARIES, IOWA CITY, IOWA}

Daughters of Ceres Records

Mildred Fox Everett Papers

Esther Mae Christiansen Grow Memoir

May Bennett Harshbarger Papers

Johnson Family Letters

Maria Margaretha Kromminga Papers

Kate Martinson Papers

Almira Safely Rutledge Diaries

Shale and Wolf Families' Letters

Jessie Field Shambaugh Papers

Clara Steen Skott Papers

Laura Gibson Smith Papers

Alma Josephine Erickson Swanson Papers

Augusta Gustafson Swanson Papers

Elizabeth Wherry Papers

Lucy Van Voorhis White Papers

\section{MANUSCRIPTS DEPARTMENT, STATE HISTORICAL} SOCIETY OF IOWA, DES MOINES, IOWA

James Delos Crain Diaries

Diary of Martha B. Howell

Mabel Irena Kent (King) Papers

Croft Pilgrim Farm Diaries

\section{SPECIAL COLLECTIONS DEPARTMENT, IOWA STATE UNIVERSITY LIBRARY, AMES, IOWA}

Celestia Lee Barker Papers

Ozias Ferree Papers

Asenath Hampton Gable Memoirs 
Charles K. Hamilton Papers

John M. Leffler Papers

William H. Mills Papers

John H. Parker Papers

Frank C. Pellett Papers

George Rae Papers

Rudolf E. Schipull Papers

Benjamin Richard Ullem Agricultural Log Book

John Thomas Winborn Papers

\section{SPECIAL COLLECTIONS DEPARTMENT, STATE HISTORICAL SOCIETY OF IOWA, IOWA CITY, IOWA}

Orlow Benjamin Barton Papers

James H. Beed Papers

Bishop, Joshua F. "Life Sketch and Personal Memories"

Robert Burroughs Business and Financial Records

Isaac N. Carr Papers

Caroline McKinley Carson Papers

Maranda J. Cline Diary

Cummins Family Papers

Dill, David Bruce. "Boy Life on the Farm, Wyman, Iowa 1896-1903"

Bertha Gabelmann Diaries

Ray L. Gribben Papers

John McLane Hamilton Diaries

Samuel A. Hammond Diaries

Howard, James R. "Making an Iowa Farmer"

Paine Howard Diaries

John M. Inman Diaries and Account Books

Jacques, Leonard B. "Life on the Farm"

Sarah Jane Kimball Papers

Krutza, Mollie. "Memories of Childhood on a Iowa Farm"

Mather-Bush Papers

John McCarty Diary

Edgar F. Miller Diaries

George Merritt Miller Diaries

Margaret Spragg Miller Diary

Molsberry, W. W. "Horse and Buggy days"

Mullen, Peg. "Six Generations in Blackhawk County, 1852-1996"

S. A. Paul Papers

Mary Eleanor Armstrong Peet Papers

Anna Mary Provines Riddell Papers

Rodgers, W. J. "Pioneer Experiences"

George Rollin Rosenberger Diaries

A. B. Rubyor Diary

Stronks, James E. “My First Twenty-two Years, 1887-1909"

Nehemias Tjernagel Papers 
"The Usher Family History"

Welday-Sauer Family Papers

Norman F. Wood Papers

Joshua R. Williams Diary

Zeller, E. R. "Trials and Triumphs of Pioneer Life"

\title{
SPECIAL COLLECTIONS DEPARTMENT, UNIVERSITY OF
} IOWA LIBRARIES, IOWA CITY

Papers of Henry Wallace

\section{UNIVERSITY OF ILLINOIS ARCHIVES, URBANA- CHAMPAIGN, ILLINOIS}

\author{
Allen Family Papers \\ Farm Cost Accounting Records \\ Russell Fenwick Farm Papers \\ Haas Family Farm Records \\ George W. Hall Farm Records \\ Harris Family Papers \\ Leonidas H. Kerrick Papers \\ Joseph E. Johnson Farm Records \\ Library \& Library School Reference File \\ Georgia S. Macklin Farm Records \\ Martin L. Mosher Papers \\ Naffziger Farm Records \\ George \& Paul Shuman Farm Records \\ Charles A. Siler Farm Records \\ H. C. Stevenson Farm Record
}

\section{WESTERN HISTORICAL MANUSCRIPT COLLECTION, COLUMBIA, MISSOURI}

\author{
Allen-Derbius Papers \\ William Fletcher Barnds Memoirs \\ Derby Bass Family Expense Books \\ Basye Family Papers \\ Belwood-Ezell Letters \\ Mrs. L. H. Benton Account Book \\ Blount Family Papers \\ Bronaugh-Bushnell Family Letters \\ Franklin Burt Papers \\ W. W. Cannon Diary \\ Cornett Family Papers \\ James Franklin Davidson Papers \\ D. Howard Doane Papers \\ Ernest M. Funk, "Ozark Farm Boy to University Professor Emeritus"
}


Mollie A. and Alice Garr Papers

Archibald Little Hager Diary

John Howard Account Book

Thomas Humphreys Diaries

June K. King Papers

Missouri Farm Bureau Federation Reports

Louis M. Monsees Papers

Charles I. Mullinax Papers

Mary H. O'Neill Diary

Randolph Casey Paul Diary

John A. Sanborn Diaries

George Carlisle Shackelford Papers

Thomas-Browning Papers

Benjamin R. Thrasher Diaries

Vanmeter Family Papers

\section{WESTERN HISTORICAL MANUSCRIPT COLLECTION, KANSAS CITY, MISSOURI}

Falor, Crabb, and McGennis Families Collection

T. J. Jennings Diary

Maschel Manring Papers

Pleasant Grove Grange Records

William E. Rider Papers

\section{WESTERN HISTORICAL MANUSCRIPT COLLECTION, ROLLA, MISSOURI}

Agricultural Wheel No. 657 (High Gate, Mo.) Records

Franklin Hoke Barnitz Papers

Bolivar Creamery Company Record Book

Bollinger-Dolle Mill and Store Records

Warren Cook Collection

Benjamin H. Creamer Papers

East Prairie Farm Club Record Book

Nelson Family Collection

Ritter and Howard Families Papers

Rosati Collection

St. Francois Agricultural and Mechanical Association Records

Elizabeth Remay Dabbs Thompson Papers

Jay Linn Torrey Scrapbook

\section{FARM NEWSPAPERS}

Iowa Homestead, 1895-1920.

Prairie Farmer, 1895-1920.

The Ruralist, 1902-1910; Missouri Ruralist, 1910-1920. 
Wallaces' Farm and Dairy, 1895; Wallaces' Farmer and Dairyman, 1895-1899; Wallaces' Farmer, 1899-1920.

\section{CENSUS MATERIALS}

1880 Federal Manuscript Census

1880 Federal Manuscript Census of Agriculture

1900 Federal Manuscript Census

1920 Federal Manuscript Census

1915 Iowa Manuscript Census

1925 Iowa Manuscript Census

United States Historical Census Data Browser, available from http://fisher.lib.virginia.edu/ census/; internet.

\section{OTHER PUBLICATIONS}

Abel, J. F. Consolidation of Schools and Transportation of Pupils. Department of the Interior, Bureau of Education, Bulletin No. 41. Washington, D. C.: Government Printing Office, 1923.

Bailey, Liberty Hyde, ed. Cyclopedia of American Agriculture. 4 volumes. New York: Macmillan, 1907-1909.

Barrett, Richard C. Report of the Superintendent of Public Instruction, State of Iowa, 1901. Des Moines: Department of Public Instruction, 1902.

Covert, Timon. Rural School Consolidation: A Decade of School Consolidation with Detailed Information from 105 Consolidated Schools. United States Department of the Interior, Office of Education, Pamphlet No. 6. Washington, D. C.: Government Printing Office, 1930.

Dewey, Evelyn. New Schools for Old: The Regeneration of the Porter School. New York: E. P. Dutton, 1919.

Gregory, Clifford V. The Good Old Days. American Farm Bureau Federation, 1938.

Iowa State College of Agriculture and the Mechanic Arts Catalog. Ames: Iowa State College, 1898-1901.

Monroe, Paul, ed. A Cyclopedia of Education. 5 volumes. New York: Macmillan, 1910-1915.

N. W. Ayer \& Son's American Newspaper Annual. Philadelphia: N. W. Ayer \& Son, 1895, 1900, 1905, 1910, 1915, 1920.

Peirce, Paul S. "Social Surveys of Three Rural Townships in Iowa." University of Iowa Monographs-Studies in the Social Sciences 5(2)(1917).

Report of the Country Life Commission. United States Senate Document No. 705, Sixtieth Congress, Second Session. Washington, D. C.: Government Printing Office, 1909.

Severance, Henry Ormal. A Guide to the Current Periodicals and Serials of the United States and Canada 1907. Ann Arbor: George Wahr, 1907.

Smith, C. Beaman and H. K. Atwood. "The Relation of Agricultural Extension Agencies to Farm Practices." In Miscellaneous Papers, U. S. Department of Agriculture Bureau of Plant Industry Circular No. 117. Washington, D. C.: Government Printing Office, 1913. 
Taylor, Carl C. Rural Sociology: A Study of Rural Problems. New York: Harper and Brothers, 1926.

Thaden, J. F. "Cost of Living on Iowa Farms." Iowa State College Agricultural Experiment Station Bulletin 238 (August 1926).

Tributes to Henry Wallace: An Incomplete Collection of Tributes to His Life and Work Which Appeared in the Press and Which Came in Personal Letters, Following his Death, Feb. 22, 1916. Des Moines: Wallace Publishing, 1919.

Twain, Mark. "Memoranda: How I Edited an Agricultural Paper Once," The Galaxy, July 1870, 133-135.

U. S. Bureau of the Census. Religious Bodies: 1906. Washington, D. C.: Government Printing Office, 1910.

. Religious Bodies: 1926. Washington, D. C.: Government Printing Office, 1930.

U. S. Department of Agriculture. Yearbook of the United States Department of Agriculture 1901. Washington, D. C.: Government Publishing Office, 1902.

Vogt, Paul L. The Church and Country Life: Report of a Conference held by the Commission on Church and Country Life under the authority of the Federal Council of Churches of Christ in America. Columbus, Ohio. December 8-10, 1915. New York: Missionary Education Movement of the United States and Canada, 1916.

Von Tungeln, George H. and Harry L. Eells, "Rural Social Survey of Hudson, Orange, and Jesup Consolidated School Districts, Blackhawk and Buchanan Counties, Iowa." Iowa State College Agricultural Experiment Station Bulletin 224 (November 1924).

Von Tungeln, George H. and W. A. Brindley. "A Rural Social Survey of Lone Tree Township, Clay County, Iowa." Iowa State College Agricultural Experiment Station Bulletin 193 (March 1920).

Von Tungeln, George H. et al. "The Social Aspects of Rural Life and Farm Tenantry, Cedar County, Iowa.” Iowa State College Agricultural Experiment Station Bulletin 217 (August 1923).

Von Tungeln, George H., J. E. Thaden, and E. L. Kirkpatrick. "Cost of Living on Iowa Farms." Iowa State College Agricultural Experiment Station Bulletin 237 (June 1926).

Wallace, Henry. Good Farming, Clear Thinking, Right Living. (Pamphlet) Des Moines: Wallace Publishing, 1916.

. Letters to the Farm Boy. 3d edition. New York: Macmillan, 1900. (Originally published Des Moines: Wallace Publishing, 1897.) . Letters to the Farm Folk. Des Moines: Wallace Publishing, 1915.

. Uncle Henry's Own Story of His Life: Personal Reminiscences. 3 volumes. Des Moines: Wallace Publishing, 1917-1919.

\section{SECONDARY SOURCES}

Books

Ahlstrom, Sydney. A Religious History of the American People. New Haven: Yale University Press, 1972. 
Bardolph, Richard. Agricultural Literature and the Early Illinois Farmer. Urbana: University of Illinois Press, 1948.

Barron, Hal S. Mixed Harvest: The Second Great Transformation in the Rural North, 1870-1930. Chapel Hill: University of North Carolina Press, 1997.

Barth, Gunther. City People: The Rise of Modern City Culture in NineteenthCentury America. New York: Oxford University Press, 1980.

Bennett, Charles O. Integrity in a Changing World: Seventy-Five Years of Industry Self-Regulation Through the Audit Bureau of Circulations. Chicago: Audit Bureau of Circulations and Mobium Press, 1989.

Berkowitz, Dan, ed. Social Meanings of News: A Text-Reader. Thousand Oaks, Ca.: Sage Publications, 1997.

Bowers, William L. The Country Life Movement in America: 1900-1920. Port Washington, NY: Kennikat Press, 1974.

Bowker's News Media Directory. 54 ${ }^{\text {th }}$ ed. 3 volumes. New Providence, N. J.: Bowker, 2004.

Carey, James W. Communication as Culture: Essays on Media and Society New York: Routledge, 1992.

Cayton, Andrew R. L. and Peter S. Onuf. The Midwest and the Nation: Rethinking the History of An American Region. Bloomington: Indiana University Press, 1990.

Cayton, Andrew R. L. and Susan E. Gray, eds. The American Midwest: Essays on Regional History. Bloomington: Indiana University Press, 2001.

Ching, Barbara and Gerald W. Creed, eds. Knowing Your Place: Rural Identity and Cultural Hierarchy. New York: Routledge, 1997.

Cohen, Bernard C. The Press and Foreign Policy. Princeton: Princeton University Press, 1963.

Cronon, William. Nature's Metropolis: Chicago and the Great West. New York: Norton, 1991.

Danbom, David B. Born in the Country: A History of Rural America. Baltimore: Johns Hopkins University Press, 1995.

. The Resisted Revolution: Urban America and the Industrialization of Agriculture, 1900-1930. Ames: Iowa State University Press, 1979.

Dankey, James P. and Wayne A. Wiegand, eds. Print Culture in a Diverse America. Urbana: University of Illinois Press, 1998.

Davidson, Cathy N. Revolution and the Word: The Rise of the Novel in America. New York: Oxford University Press, 1986

Davidson, Cathy N., ed. Reading in America: Literature and Social History. Baltimore: Johns Hopkins University Press, 1989.

Demaree, Albert Lowther. The American Agricultural Press, 1819-1860. New York: Columbia University Press, 1941.

Denning, Michael. Mechanic Accents: Dime Novels and Working Class Culture in America. Revised edition. London: Verso, 1998. (Originally published 1987.)

Dorn, Jacob Henry. Washington Gladden: Prophet of the Social Gospel. Columbus: Ohio State University Press, 1967.

Dykstra, Robert. Bright Radical Star: Black Freedom and White Supremacy on the Hawkeye Frontier. Cambridge: Harvard University Press, 1993. 
Ernst, Eldon G. Moment of Truth for Protestant America: Interchurch Campaigns Following World War One. Missoula, Montana: American Academy of Religion and Scholars' Press, 1974.

Evans, James F. Prairie Farmer and WLS: The Burridge D. Butler Years. Urbana: University of Illinois Press, 1969.

Evans, James F. and Rodolfo N. Salcedo. Communications in Agriculture: The American Farm Press. Ames: Iowa State University Press, 1974.

Faragher, John Mack. Sugar Creek: Life on the Illinois Prairie. New Haven: Yale University Press, 1986.

. Women and Men on the Overland Trail. New Haven: Yale University Press, 1979.

Fink, Deborah. Open Country, Iowa: Rural Women, Tradition and Change. Albany: State University of New York Press, 1986.

Finke, Roger and Rodney Stark. The Churching of America, 1776-1990: Winners and Losers in Our Religious Economy. New Brunswick: Rutgers University Press, 1992.

Fox, Richard Wightman and T. J. Jackson Lears, eds. The Culture of Consumption: Critical Essays in American History, 1880-1980. New York: Pantheon, 1983.

Fuller, Wayne E. The Old Country School: The Story of Rural Education in the Middle West. Chicago: University of Chicago Press, 1982.

. One-Room Schools of the Middle West: An Illustrated History. Lawrence: University Press of Kansas, 1994.

Fusonie, Alan and Leila Moran, eds. Agricultural Literature: Proud HeritageFuture Promise, A Bicentennial Symposium, September 24-26, 1975. Washington, DC: Associates of the National Agricultural Library and the Graduate School Press, United States Department of Agriculture, 1977.

Garvey, Ellen Gruber. The Adman in the Parlor: Magazines and the Gendering of Consumer Culture, 1880s to 1910s. New York: Oxford University Press, 1996.

Gates, Paul Wallace. The Farmer's Age: Agriculture, 1815-1860. New York: Holt, Rinehart, and Winston, 1960.

Gaustad, Edwin Scott. Historical Atlas of Religion in America. Revised edition. New York: Harper and Row, 1972.

Gilmore, William J. Reading Becomes a Necessity of Life: Material and Cultural Life in Rural New England, 1780-1835. Knoxville: University of Tennessee Press, 1989.

Gjerde, Jon. The Minds of the West: Ethnocultural Evolution in the Rural Middle West, 1830-1917. Chapel Hill: University of North Carolina Press, 1997.

Gray, William S. and Ruth Monroe. The Reading Interests and Habits of Adults: A Preliminary Report. New York: MacMillan, 1930.

Gutjahr, Paul C. An American Bible: A History of the Good Book in the United States, 1777-1880. Stanford: Stanford University Press, 1999.

Hahn, Stephen and Jonathan Prude, eds. The Countryside in the Age of Capitalist Transformation: Essays in the Social History of Rural America. Chapel Hill: University of North Carolina Press, 1985.

Hamilton, Milton W. The Country Printer: New York State, 1785-1830. New York: Columbia University Press, 1936. 
Handy, Robert T. Undermined Establishment: Church State Relations in America, 1880-1920. Princeton: Princeton University Press, 1991.

Handy, Robert T., ed. The Social Gospel in America, 1870-1920: Gladden, Ely, Rauschenbusch. New York: Oxford University Press, 1966.

Hoffman, John, ed. A Guide to the Study of Illinois. New York: Greenwood Press, 1991.

Hofstadter, Richard. The Age of Reform: From Bryan to FDR. New York: Vintage, 1955.

Holt, Marilyn Irvin. Linoleum, Better Babies of the Modern Farm Woman, 1890-1930. Albuquerque: University of New Mexico Press, 1995.

Hudson, Winthrop S. Religion in America: A Historical Account of the Development of American Religious Life. Third edition. New York: Scribners, 1981.

Hurt, R. Douglas. American Agriculture: A Brief History. Ames: Iowa State University Press, 1994.

Jackson-Lears, T. J. Fables of Abundance: A Cultural History of Advertising in America. New York: Basic Books, 1994.

Jellison, Katherine. Entitled to Power: Farm Women and Technology, 1913-1963. Chapel Hill: University of North Carolina Press, 1993.

Jensen, Richard J. and Mark Friedberger. Education and Social Structure: An Historical Study of Iowa, 1870-1930. Chicago: The Newberry Library, 1976.

Johnson, Glenn L. et al. eds. A Study of Managerial Processes of Midwestern Farmers. Ames: Iowa State University Press, 1961.

Kaestle, Carl F. et al. Literacy in the United States: Readers and Reading Since 1880. New Haven: Yale University Press, 1991.

Kennedy, David M. Over Here: The First World War and American Society. Oxford: Oxford University Press, 1980.

Kirkendall, Richard S. Uncle Henry: a Documentary Profile of the First Henry Wallace. Ames: Iowa State University Press, 1993.

Kline, Ronald R. Consumers in the Country: Technology and Social Change in Rural America. Baltimore: Johns Hopkins University Press, 2000.

Leonard, Thomas C. News For All: America's Coming-of-Age with the Press. New York: Oxford University Press, 1995.

Lord, Russell. The Wallaces of Iowa. Boston: Houghton-Mifflin, 1947.

Malin, James C. The Grassland of North America: Prolegomena to its History with Addenda. Lawrence, Kansas: published by the author, 1956.

Madison, James, ed. Heartland: Comparative Histories of the Midwestern States. Bloomington: Indiana University Press, 1988.

Marsden, George M. Fundamentalism and American Culture: The Shaping of Twentieth Century Evangelicalism: 1870-1925. Oxford: Oxford University Press, 1980.

. The Soul of the American University: From Protestant Establishment to Established Nonbelief. New York: Oxford University Press, 1994.

McConnell, Grant. The Decline of Agrarian Democracy. Berkeley: University of California Press, 1953.

McMurry, Sally. Families and Farmbouses in Nineteenth Century America: Vernacular Design and Social Change. Knoxville: University of Tennessee Press, 1997. (First published Oxford University Press, 1988.) 
- Transforming Rural Life: Dairying Families and Agricultural Change, 1820-1885. Baltimore: Johns Hopkins University Press, 1995.

Miller, John E. Becoming Laura Ingalls Wilder: The Woman Behind the Legend. Columbia: University of Missouri Press, 1998.

Mott, Frank Luther. American Journalism: A History, 1690-1960. 3rd Edition. New York: Macmillan, 1962.

. A History of American Magazines, 1850-1865. Cambridge: Harvard University Press, 1938.

Murphy, Donald R. What Farmers Read and Like: A Record of Experiments with Readership on Wallaces Farmer and Wisconsin Agriculturist, 1938-1961. Ames: Iowa State University Press, 1962.

Neth, Mary. Preserving the Family Farm: Women, Community, and the Foundations of Agribusiness in the Midwest, 1900-1940. Baltimore: Johns Hopkins University Press, 1995.

Noll, Mark A. A History of Christianity in the United States and Canada. Grand Rapids: Eerdmans, 1992.

Nugent, Walter. Structures of American Social History. Bloomington: Indiana University Press, 1981.

Ogilvie, William Edward. Pioneer Agricultural Journalists: Brief Biographical Sketches of Some of the Early Editors in the Field of Agricultural Journalism. Chicago: Arthur J. Leonard, 1927.

Ohmann, Richard. Selling Culture: Magazines, Markets, and Class at the Turn of the Century. New York: Verso, 1996.

Passet, Joanne Ellen. Sex Radicals and the Quest for Women's Equality. Urbana: University of Illinois Press, 2003.

Pawley, Christine. Reading on the Middle Border: The Culture of Print in LateNineteenth-Century Osage, Iowa. Amherst: University of Massachusetts Press, 2001.

Pederson, Jane Marie. Between Memory and Reality: Family and Community in Rural Wisconsin, 1870-1970. Madison: University of Wisconsin Press, 1992.

Persons, Stow. American Minds: A History of Ideas. New York: Holt, Rinehart \& Winston, 1958.

Phillips, Paul T. A Kingdom on Earth: Anglo-American Social Christianity, 1880-1940. University Park: Pennsylvania State University Press, 1996.

Reynolds, David R. There Goes the Neighborhood: Rural School Consolidation at the Grass Roots in Early Twentieth-Century Iowa. Iowa City: University of Iowa Press, 1999.

Rohrbough, Malcolm J. The Trans-Appalachian Frontier: People, Societies, and Institutions, 1775-1850. New York: Oxford University Press, 1978.

Schlebecker, John T. and Andrew W. Hopkins. A History of Dairy Journalism in the United States, 1810-1950. Madison: University of Wisconsin Press, 1957.

Schwieder, Dorothy. 75 Years of Service: Cooperative Extension in Iowa. Ames: Iowa State University Press, 1993.

Sherman, William L., ed. Iowa's Country Schools: Iandmarks of Learning. Parkersburg, IA: Mid-Prairie Books, 1998.

Shortridge, James R. The Middle West: Its Meaning in American Culture. Lawrence: University Press of Kansas, 1989. 
Socolofsky, Homer E. Arthur Capper: Publisher, Politician, and Philanthropist. Lawrence: University Press of Kansas, 1962.

Stuntz, Stephen Conrad, comp. List of the Agricultural Periodicals of the United States and Canada Published During the Century July 1810 to July 1910. Edited by Emma B. Hawks. Washington, DC: United States Government Printing Office, 1941.

Theobald, Paul. Call School: Rural Education in the Midwest to 1918. Carbondale: Southern Illinois Univcrsity Press, 1995.

Tucker, Gilbert M. American Agricultural Periodicals: An Historical Sketch. Albany: Privately Printed, 1909.

Wagenaar, Larry J. and Robert P. Swierenga, eds. Dutch Enterprise: Alive and Well in North America. Pella, Iowa: Central College, 1999.

Wall, Joseph Frazier. Iowa: A Bicentennial History. New York: Norton, 1978.

West, Elliot. Growing Up With The Country: Childhood on the Far Western Frontier. Albuquerque: University of New Mexico Press, 1989.

White, Ronald C. and C. Howard Hopkins. The Social Gospel: Religion and Reform in Changing America. Philadelphia: Temple University Press, 1976.

Wiebe, Robert. The Search for Order, 1877-1920. New York: Hill and Wang, 1967. Wilson, Charles Reagan, ed. The New Regionalism. Jackson: Univ. Press of Mississippi, 1998.

\section{Unpublished Works}

Brantley, Billy Clyde. "History of the Missouri Ruralist, 1902 through 1955." M. A. thesis, University of Missouri-Columbia, 1958.

Cassady, David R. "The Content of the Rural Weekly Press in Illinois in 1882." Ph. D. diss., University of Iowa, 1980.

Fitzpatrick, John William. “The Farm Press of America, 1900-1925.” M. S. thesis, University of Wisconsin, 1926.

Fry, John J. "Reading, Reform, and Rural Change: The Midwestern Farm Press, 1895-1920." Ph. D. diss, University of Iowa, 2002.

Longsdorf, Lisle Leslie. “The Agricultural Press of America, 1850-1900.” M. S. thesis, University of Wisconsin, 1926.

Lutzky, Seymour. “The Reform Editors and their Press." Ph. D. diss., University of Iowa, 1951.

Nafziger, Ralph Otto. "The History and Influence of the Farm Press in Wisconsin." B. S. thesis, University of Wisconsin, 1920.

Rife, Gladys Talcott. “Iowa's Rural Women's Columnists, Especially of the Fifties: Their Cultural and Historical Import in a Comparative Context." Ph. D. diss., University of Iowa, 1988.

Riney-Kehrberg, Pamela. "Farm Childhood and Life Choices: The American Midwest, 1870-1920." Paper presented at the Organization of American Historians Midwestern Regional Conference, Ames, Iowa, 5 August 2000.

Seaman, Gerald LeRoy. "A History of Some Early Iowa Farm Journals (before 1900)." M. S. thesis, Iowa State College, 1942.

Shulman, Stuart William. "The Origin of the Federal Farm Loan Act: Agenda-Setting in the Progressive Era Print Press.” Ph. D. diss., University of Oregon, 1999. 
Van Derhoof, Jack. "Eastern and Mid-Western Agricultural Journalism, 1860-1900.” Ph. D. diss., Columbia University, 1951.

Wheeler, Kenneth. "The Apex of Midwestern Culture?: Recent Historiography and Reinterpretations of the Midwest." Paper presented at the Organization of American Historians Midwestern Regional Conference, 4 August 2000.

Yoder, Franklin. "Diverging Paths: Progressive Elites and Immigrants in the PostFrontier Midwest." Paper presented to the Newberry Seminar in Rural History, Chicago, 4 December 1999.

- "A Rural Kaleidoscope: Property, Mobility, and Ethnic Diversity in the Middle West.” Ph. D. diss., University of Chicago, 1999.

\section{Articles}

Aley, Ginette. “'Knotted Together Like Roots in the Darkness': Rural Midwestern Women and Region-A Bibliographic Guide," Agricultural History 77(3)(Summer 2003): 453-481.

Argersinger, Peter H. “The People's Past: Teaching American Rural History." The History Teacher 10(3)(May 1977): 403-424.

Atwood, Roy Alden. "The Rural Press and the Electronic Mythos: Images and Interlocking Interests in Southeastern Iowa, 1900-1917." Journalism History 10(1-2)(Spring-Summer 1983): 18-24.

Barron, Hal S. "Rediscovering the Majority: The New Rural History of the Nineteenth Century North." Historical Methods 19(4)(Fall 1986): 141-152.

Boyer, Paul. "In Search of the Fourth 'R': The Treatment of Religion in American History Textbooks and Survey Courses." The History Teacher 29(2)(February 1996): 195-216.

“A Brief History of Prairie Farmer." Decatur, IL: Farm Progress Companies, n. d.

“A Brief History of Wallaces Farmer." Des Moines: Farm Progress Companies, n. d. Chaffee, Steven H. "George Gallup and Ralph Nafziger: Pioneers of Audience Research." Mass Communication and Society 3(2/3)(Spring/Summer 2000): 317-327.

Danbom, David B. "The Professors and the Plowmen in American History Today." Wisconsin Magazine of History 69(2)(Winter 1985-86): 106-128.

. "Rural Education Reform and the Country Life Movement, 1900-1920." Agricultural History 53(2)(April 1979): 462-474.

Demaree, Albert Lowther. "The Farm Journals, Their Editors, and Their Public, 1830-1860." Agricultural History 15(4)(October 1941): 182-188.

Ellsworth, Clayton. "Theodore Roosevelt's Country Life Commission," Agricultural History 34 (Fall 1960): 155-172

Evans, James F. “Clover Leaf: The Good Luck Chain, 1899-1933," Journalism Quarterly 46 (Autumn 1969): 482-491.

Faragher, John Mack. "History from the Inside-Out: Writing the History of Women in Rural America." American Quarterly 33(5)(1981): 537-557.

Farrell, Richard T. “Advice to Farmers: The Content of Agricultural Newspapers, 1860-1910." Agricultural History 51(1)(January 1977): 209-217.

Folkerts, Jean. "Functions of the Reform Press." Journalism History 12(1)(Spring 1985): 22-25. 
Ford, Stephen A. and Emerson M. Babb. "Farmer Sources and Uses of Information." Agribusiness 5(5)(September 1989): 465-476.

Galambos, Louis. “The Agrarian Image of the Large Corporation, 1879-1920: A Study in Social Accommodation." Journal of Economic History 28(3)(September 1968): 341-362.

Hart, D. G. "The Failure of American Religious History." The Journal of the Historical Society 1(1)(Spring 2000): 1-31.

Henretta, James A. "Families and Farms: Mentalité in Pre-Industrial America." William and Mary Quarterly 35(1)(January 1978): 3-32.

Hicks, John D. “The Western Middle West, 1900-1914." Agricultural History 20(2)(April 1946): 65-77.

Johnson, Keach. "Roots of Modernization: Educational Reform in Iowa at the Turn of the Century." The Annals of Iowa 50(8)(Spring 1991): 892-918.

Jones, David C. "There is Some Power About the Land: The Western Agrarian Press and Country Life Ideology." Journal of Canadian Studies 17(3)(Fall 1982): 96-108.

Kirkendall, Richard. "The Central Theme of American Agricultural History." Agriculture and Human Values 1(2)(Spring 1984): 6-8.

Kunze, Joel. "Shameful Venality: The Pierce-Wallace Controversy and the election of 1896." The Palimpsest 71(1)(1990): 2-11.

Lauck, Jon. “'The Silent Artillery of Time:' Understanding Social Change in the Rural Midwest," Great Plains Quarterly 19(4)(Fall 1999): 245-256.

Lemmer, George F. "Early Agricultural Editors and their Farm Philosophies." Agricultural History 31(4)(October 1957): 3-23.

Madison, James H. “John D. Rockefeller's General Education Board and the Rural School Problem in the Midwest, 1900-1930." History of Education Quarterly 24(2)(Summer 1984): 181-199.

. "Reformers and the Rural Church, 1900-1950." Journal of American History 73(3)(December 1986): 645-668.

Malin, James. "The Vanity Histories." Kansas Historical Quarterly 21 (Winter 1955): 498-643.

Marti, Donald B. "Agricultural Journalism and the Diffusion of Knowledge: The First Half-Century in America." Agricultural History 54(1)(January 1980): 28-37.

McMurry, Sally. "Who Read the Agricultural Journals?: Evidence from Chenango County, New York, 1839-1865.” Agricultural History 63(4)(Fall 1989): 1-18.

Mott, Frank Luther. "Farm, Stock, and Dairy Journals." Palimpsest 44(8)(August 1963): 341-360.

Murphy, Donald R. “The Centennial of a Farm Paper.” Palimpsest 37(9)(September 1956): 449-480.

Neth, Mary. "Gender and the Family Labor System: Defining Work in the Rural Midwest." Journal of Social History 7(3)(Spring 1994): 563-577.

Noll, Mark A. "Linking Billy Sunday and the Mystique of the Middle West to the Religious History of Iowa." The Annals of Iowa 55(4)(Fall 1996): 362-368.

Pawley, Christine. "'Not Wholly Self Culture': The Shakespearean Women's Club, Osage, Iowa, 1892-1920." Annals of Iowa 56(1/2)(Winter/Spring 1997): 12-45. 
Peters, Scott J. and Paul A. Morgan. "The Country Life Commission: Reconsidering a Milestone in American Agricultural History." Agricultural History 78(3)(Summer 2004): 289-316.

Reynolds, David R. “The Making of Buck Creek: Country Life Reform, Religion, and Rural School Consolidation." The Annals of Iowa 58(4)(Fall 1999): 351-387.

Riney-Kehrberg, Pamela. "Helping Ma and Helping Pa: Iowa's Turn-of-the-Century Farm Children." The Annals of Iowa 59(2)(Spring 2000): 115-140.

. "Women, Technology, and Rural Life: Some Recent Literature." Technology and Culture 38(4)(October 1997): 943-953.

Rome, Adam Ward. "American Farmers as Entreprencurs, 1870-1900." Agricultural History 56(4)(October 1982): 37-49.

Ross, Earle D. “A Gencration of Prairic Historiography." Mississippi Valley Historical Review 33(3)(December 1946): 391-410.

Rubin, Joan Shelley. "What is the History of the History of Books?" Journal of American History 90(2)(Scptember 2003): 555-575

Schapsmeier, Edward L. and Frederick H. Schapsmeier. "The Wallaces and Their Farm Paper: a Story of Agrarian Leadership." Journalism Quarterly 44(2)(1967): 289-296.

Schwieder, Dorothy. "Education and Change in the Lives of Iowa Farm Women, 1900-1940." Agricultural History 60(2)(1986): 200-215.

. "The New Rural History: A Subject Whose Time has Come." The Historian 58(4)(Summer 1996): 844-849.

Shulman, Stuart W. “The Progressive Era Farm Press." Journalism History 25(1)(Spring 1999): 26-35.

Smith, C. R. F. “The Iowa Homestead.” Palimpsest 11(6)(June 1930): 229-241.

Socolofsky, Homer E. "The Development of the Capper Farm Press." Agricultural History 31(4)(October 1957): 34-43.

Sorenson, Douglas. "Farm magazines: A Century and a Half, 1819-1869." AgriMarketing 7(8)(August 1969): 125-128.

Swanson, Merwin. "The 'Country Life Movement' and the American Churches." Church History 46(3)(September 1977): 358-373.

Swierenga, Robert P. "The Little White Church: Religion in Rural America." Agricultural History 71(4)(Fall 1997): 415-441.

. "The New Rural History: Defining the Parameters." Great Plains Quarterly 1(4)(Fall 1981): 211-22.3.

"Theoretical Perspectives on the New Agricultural History: From Environmentalism to Modernization." Agricultural History 56(3)(July 1982): 495-502.

. "Towards the 'New Rural History': A Review Essay." Historical Methods Newsletter 6(2)(March 1973): 111-122.

Theobald, Paul. "Democracy and the Origins of Rural Midwest Education: A Retrospective Essay," Educational Theory 38(3)(Summer 1988): 363-367.

Thompson, Arthur T. “Wallace's Farmer." Palimpsest 11(6)(June 1930): 242-255.

Vaught, David. "State of the Art-Rural History, or Why Is There No Rural History of California?" Agricultural History 74(4)(Fall 2000): 759-774. 
Page Intentionally Left Blank 


\section{Index}

A

Agricultural education, 118, 120-122, 129-131, 155

Agricultural newspapers, see Farm newspapers

Agricultural press, see Farm newspapers

Allen, Ralph

biography, 86-87

reading, 49,87

Appleby, Joyce, 37

Atkinson, James, 6, 17, 34

Atlantic, 48, 61

Atwood, H. K., 67-69

Audit Bureau of Circulations, 4-5, 28

\section{B}

Bailey, John Campbell

biography, 80

reading, 38-41, 43, 50, 80-81

Barron, Hal, xvii, 129, 136-137

Barth, Gunther, 40, 56

Beed, James H., 47

Beresford, Rex, 97, 99, 100, 151

Bible, 43, 46

Bowers, William, xxi, 36, 136

Brantley, Billy, 12

Butler, Burridge, 7, 28-29, 166

C

Capper, Arthur, 9, 12, 29-30, 34, 165

Carey, James, 159

Carr, Isaac N.

biography, 81-82

reading, $40,47,49,57,82$
Carroll, Matthew V., 8-9, 29-30

Case, John F., 9, 33-34, 143

rural church, 99, 102, 104-105

rural schools, 124,128

Children, labor of, 149

Christian periodicals, 50

Clark, G. Kitson, 39

Commission on Country Life, see Country Life Commission

Communities of print, 53-56, 147-149, 160

Cooper, Laura Whitney, 49

Cornett, Winifred Davis, 51

Country Life Commission, xx-xxi, 31, 93, $118-119,125$

Country Life Movement, xviii, xx-xxii, 36, 157-158

rural church, 90, 96, 105-106, 112

rural family, 144-145, 154-155

rural schools, 118-119, 127

Country schools, see Rural schools

County agricultural schools, 128-129

Cummins, Dan

biography, 84-85

reading, $40,41,55,85$

D

Danbom, David, xxi, xxviii, 136, 146

Daughters of Ceres, 41, 55-56, 148

Davidson, Cathy, 52

Demaree, Albert Lowther, 161

Dewey, Evelyn, 122

Dewey, John, 117, 122 
Dickens, Charles, 47

Dime novels, 47

Divorce, 144

Domestic science, 118, 142, 145, 153, 157

E

Education reformers, 117-120, 138, 157

Evans, James, xxiii, 2

\section{F}

Falor, Charles, 40, 50-51

Faragher, John Mack, 139

Farm boys, 150-152

Farm girls, 152-154

Farm newspapers

advertising, 22-23

agricultural education, 120-122

agricultural information, 18-19

circulation, 4-5, 15-16, 167

circulation policy, 13-14

classifications, xxiii

consolidation, 3, 166-167

content, 16-22, 157-158

contests, 12

definition, xxiii

departments, 19-20

editorials, 16-18

editorial voice, 17

editors, 33-36, 158

farm family, 140-156, 158

feature articles, 19

growth, 1-3, 157

history, 2-4

home departments, 20, 140, 160

letters to the editor, 20-22

multiple subscriptions, 41

national, xxiv

number, xxiii

premiums, 11

publishers, 26-33, 35-36, 158

reach of, xix, 14

readers, $21-22,40-43,67,157$

agricultural education, 129-131, 155

children, 154-156

family roles, 145-146

farm owners, 70-71, 74-75

hired men, 70-71 occupations, 73,75

rural church, 108-113

rural school consolidation, 131-136

sharecroppers, $70-71$

tenants, 70-71, 75-76

regional, xxiv, 14

role of, xix

rural church, 93-105, 158

rural school consolidation, 123-127, 158

serialized fiction, 20

specialized, xxiv

state, 15

subscription agents, 12-13

subscription clubs, 10-11, 72-79

subscription drives, 3

subscription policy, 1-2

subscription rates, 10

used by historians, 161-163

used by rural Midwesterners, 157-161

Farm press, see Farm newspapers

Ferree, Ozias, 40, 54-55

Field, Jessie, 121-122

Fink, Deborah, 143

Fuller, Wayne, 130

G

Gender division of labor, 140, 145

Gladden, Washington, 107

Graham, H. W., 97-98

Great Depression, 165-166

Gregory, Clifford, 7, 33, 97, 102, 104

Gutjahr, Paul, 43, 46

H

Harper's, 48

Harshbarger, May Bennett, 83-84

Harvey, Marie Turner, 122

Henretta, James, 139

Hofstadter, Richard, xviii

Holt, Marilyn Irvin, 147

Howard, James R., 55

I

Illinois State Historical Library, 80

Inman, John M., 49

Iowa Homestead

agricultural education, 121-122 
history, 5-6

home department, 147-148

"Pleasant Fields of Holy Writ," 93-94

readers, $41-43,80,82,85$

agricultural education, 130

rural church, 109-110

rural school consolidation, 131-134

rural church, 93-94, 99

rural school consolidation, 123, 127

Iowa Women's Archives, 58

J

Jellison, Katherine, 145, 147

Joslyn, Harry A., 40, 49

$\mathbf{K}$

Kimball, Sarah Jane, 47, 56

L

Labor saving devices, 140, 141-142

Ladies Home Journal, 48

Leonard, Thomas, 13, 56, 160

Local newspapers, 39-40

Lower Midwest, xxv, 79

\section{M}

Madison, James, 107, 136

Magazines, 47-49

Marriage, 143-144

McMurry, Sally, 66-67, 73, 76-77

McNutt, M. B., 97, 99, 111

Mills, William H., 11, 160-161

biography, 72

subscription club, 67, 72-79

Missouri Ruralist

agricultural education, 122

history, 8-9

readers, 86

rural school consolidation, 124,135

Monsees, Louis

biography, 85-86

reading, 43,86

\section{$\mathbf{N}$}

Nafziger, Ralph, 41, 66

Neth, Mary, xxi, 145, 147

New Rural History, xviii-xix

Nugent, Walter, xvii
O

O’Neill, Mary H., 56-57

One-room schools, see Rural schools

Outlook, 48

P

Paul, S. A., 46, 54-54

Pawley, Christine, 40, 47, 52, 56

Peirce, Paul S., 70

Perriam, Jonathan, 7

Pierce, Dante M., 6, 165

Pierce, James M., xx, xxiii, 5-6

biography, 26-28

rural church, 94, 97, 104

rural school, 128, 131

Poultry raising, 57-58, 142-143

Prairie Farmer

agricultural education, 121-122

history, 6-8

readers, 87

rural church, 109-111

rural school consolidation, 134

rural school consolidation, 124, 127

Progressivism, xvii-xviii, xxii-xxiii, 137,

157-159

$\mathbf{R}$

Readers, 21-22

books, 43-47

Christian periodicals, 50, 81

community building, 53-56

enjoyment, 56-57

farming information, 57

farm newspapers, 40-43, 67

local newspapers, 39-40

magazines, 47-49

urban newspapers, 49-50

women, 51-53

Reading clubs, 55, 83-84

Report of the Country Life Commission, see

Country Life Commission

Reynolds, David, xxi, xxii, 137

Rock Island Historical Society, 80

Rural church

definition, 89-90

diversity, 90, 100-101

history, 90-92 
membership, 90-91

number, 90-91

pastor, 91-92

roles, 89-90, 96-98

social center, 96-98

Rural marriage, see Marriage

Rural outmigration, 92, 119

Rural readers, see Readers

Rural school consolidation, 118-119, 123-127, 131-138

Rural schools

control, 115-116, 119

curriculum, 115-116

improvements, 127-129

numbers, 115

teachers, 116, 128

Rural women, see Women

\section{$S$}

Salcedo, Rodolfo, xxiii, 2

Sanborn, John

biography, 59-61

reading, 43, 47, 49, 53, 60-63, 85

Saturday Evening Post, 48

Schwieder, Dorothy, 147

Seipp, Lizzie Shale, 40

Shambaugh, Jessie Field, see Field, Jessie

Shulman, Stuart, 159

Smith, C. Beaman, 67-69

Smith, Laura Gibson, 53

Social Gospel, 106-107, 112-113, 157

Swanson, Merwin, 107

Swierenga, Robert, 89

T

Taylor, Carl C., 71

Temperance literature, 51

Theobald, Paul, xxii, 137

Thompson, John, 6

Tjernagel, Nehemias, 51

Twain, Mark, 25-26, 32, 65

$\mathbf{U}$

Uncle Tom's Cabin, 46-47, 56

Urban newspapers, 49-50

V

Van Derhoof, Jack, 4, 7, 18
W

Wallace, Henry

biography, 30-32, 103

circulation policy, 14

farm newspaper classifications, 1, 17

rural church, 93-96, 98-100

rural pastor, 101-102

rural school consolidation, 124-126

Wallace, Henry A., 8, 31, 165

Wallace, Henry C., 8, 31, 103, 125

Wallace, Nancy Cantwell, 55-56, 148

Wallaces' Farmer

agricultural education, 120-122

"Hearts and Homes" department, $55-56,148$

history, 8

readers, 41-43, 83-85

agricultural education, $129-130$

rural church, 108-111

rural school consolidation, 134-135

rural school consolidation, 124-126

"Sabbath School Lesson," 93-94, 96

subscribers

economic status, 74-77

education, 79

ethnicity, 77-78

farm owners, 74-75

occupations, 73,75

tenants, 75-76

successful rural churches, 103-104

Western Historical Manuscript Collection, 59

White, Lucy Van Voorhis

biography, 58-59

Christian works, 50, 59, 107-108

poultry raising, 57-58

reading, $47,50,52,57-58,82$

Wilder, Laura Ingalls, 143

Wilson, Christopher, 48-49

Women, 140-149

communities of print, 147-149, 160

labor saving devices, 140

reading, $51-53$

satisfaction, 140, 141-147

Women farmers, 143-144

World War I, xxiii, 103

Y

Youth's Companion, 48, 81 